Universidade de São Paulo

Instituto de Química

\title{
ESTUDOS SOBRE A CARACTERIZAÇÃO E A ESTABILIDADE DE AMOSTRAS DE SEDIMENTOS DO RIO TIETÊ, S.P.
}

José Eduardo Bevilacqua

Tese de Doutoramento

Prof.Dr.Jaim Lichtig

Orientador

São Paulo

1996 
BIBLIOTECA INSTITUTO DE QUIMICA

Universjiaca de Sào Paulo

Ao Plano Divino

que inspira, ilumina e traz sabedoria aos Homens de Bem na terra. 
Um agradecimento especial

à Neusinha, meu grande e único amor,

por toda a compreensão e carinho

que me dedica todos os dias 
dedico este trabalho a meus Pais

Haroldo e Maria Helena

por mostrarem tanta dedicação e amor em cada gesto 


\section{Agradecimentos}

Ao Prof. Dr. Jaim Lich'ig, por todo apoio, amizade e orientação ao longo de todos esses importantes anos de minha vida.

Ao nosso estagiário e amigo Benedito Cesário da Rocha, por toda a dedicação que teve conosco neste trabalho.

À Prof.Dra Haidê Lentz Fiedler, por todo o apoio prestado neste tema de estudo.

Aos funcionários e amigos do Instituto de Química da USP, pela oportunidade de convívio e pelo apoio concedido.

Aos amigos do laboratório, em particular Ulisses, Hélio, P.C., Kadovaki, Molla, Murillo, Rosane, Orlando, Margarida, Marcos Rogéria, Sidão, e outros que eu possa ter esquecido.

Aos amigos do laboratório da Prof. Lílian, por todo apoio, amizade e pelo "chá das 4".

À geóloga e amiga Ivone Silveira da Silva pelas importantes discussões, por todo o apoio nas análises de MEV, e pelo carinho que sempre me dedicou.

Ao biólogo MSc. Geraldo G.J.Eysink e ao geólogo MSc. Roberto "Laite" Pádula de Moraes da CETESB, bem como toda a equipe, por todo o apoio técnico-logístico prestado desde o início deste trabalho

Ao amigo Prof. Dr. Antonio Aparecido Mozeto, da UFSCar, pelas importantes discussões, pela cor fiança em mim depositada e principalmente pela grande e maravilhosa amizade.

À amiga Prof. Dra. Sílvia Helena Pires Serrano, pelo incentivo e fundamentais discussões, além cle ter produzido um eletrodo tão bom como o de sulfeto.

Ao Prof.Dr. Jorge Masini pelas importante atenção que sempre dedicou desde o início deste trabalho. 
À Alice Momoyo Sakuma do Instituto Adolfo Lutz e aos seus colaboradores Ricardo e Sérgio pelo fundamental apoio que nos prestaram na realização das determinações por absorção atômica.

Ao Prof.Dr. Rolf Roland Weber do Instituto Oceanográfico da USP pelo uso do equipamento de ultrassom.

À Prof. Dra Maria Teresa M. de Miranda pelo uso do equipamento shaker.

À Prof. Dra. Ana Maria Felicíssimo, pelo uso das depend6encias do laboratório UMBRAL e do glove-box.

À Prof.Dra. Maria Olímpia O.Resende do IQSC-USP, pela dedicação nas análises dos ácidos húmicos dos sedimentos.

À Luzia da Central Analítica, pelas análises elementares.

Aos "novos amigos" da UFSCar, por todo o apoio que têm me dado.

Ao CNPq, pelo auxílio concedido.

Enfim, a todos que direta ou indiretamente auxiliaram na realização deste trabalho, 


\section{Sumário Geral}

índice de figuras

iii

índice de tabelas

vi

agradecimentos

v

resumo

vii

abstract

viii

\section{INTRODUÇÃO}

I.1. aspectos gerais sobre os sedimentos 1

I.2. metais pesados nos sedimentos 2

I.3. especiação química de metais em sedimentos 5

I.4. métodos de extração sequencial 6

I.5. extração parcial de metais pesados com $\mathrm{HCl}$ diluído 11

I.6. outras metodologias utilizadas na caracterização de sedimentos 12

I.6.1. planejamento de trabalho 13

$\begin{array}{lr}\text { I.6.2. amostragem } & 13\end{array}$

$\begin{array}{ll}\text { I.6.3. procedimentos e resultados analíticos } & 14\end{array}$

$\begin{array}{ll}\text { I.7. preservação de amostras } & 15\end{array}$

$\begin{array}{ll}\text { I.8. medidas de potencial redox } & 16\end{array}$

$\begin{array}{lr}\text { I.9. medidas de } \mathrm{pH} & 19\end{array}$ 
I.10. Espectrofotometria de Absorção Atômica na determinação de metais pesados

I.11. Sulfeto Ácido Volátil (SAV) 21

I.12. Granulometria 23

I.13. análise textural por Microscopia Eletrônica e Varredura 25

I.14. determinação de carbono total 26

I.15. isolamento e caracterização de ácidos húmicos 27

$\begin{array}{ll}\text { Objetivos } & 28\end{array}$

\section{PARTE EXPERIMENTAL}

2.1. a área de estudo: o Rio Tietê. 30

2.2. a qualidade ambiental do Tietê 33

2.3. coleta de amostras de sedimentos 34

2.4. acondicionamento das amostras de sedimentos 36

2.5. determinação do potencial redox 38

2.6. determinação de $\mathrm{pH} \quad 39$

2.7. determinação de sulfeto ácido volátil 40

2.7.1.estabelecimento da técnica analítica para SAV 40

2.7.1.1. Biamperometria 40

2.7.1.2. Polarografia de Pulso Diferencial 41

2.7.1.3. Potenciometria com eletrodo íon-seletivo 42

2.7.1.4. sistema de "geração" de sulfeto ácido volátil 43

2.8. determinação de metais pesados por espectrofotometria de
absorção atômica

2.8.1. método de extração sequencial 46 
2.9.análise granulométrica 53

2.10. análise textural 54

2.11. análise de carbono total 54

2.12. isolamento e caracterização de ácidos húmicos 55

\section{RESULTADOS E DISCUSSÃO}

3.1. esiudo da estabilidade das amostras através das medidas de $\mathrm{E}_{\mathrm{H}}$ e de $\mathrm{pH}$

3.2. determinação de sulfeto ácido volátil por biamperometria

3.3. determinação de sulfeto ácido volátil por polarografia de pulso diferencial

3.4. determinação de sulfeto ácido volátil por eeletrodo íon-seletivo $\quad 67$

3.5. determinações com o sistema gerarıor de SAV 71

3.6. determinacão de SAV em amostras do Tietê 73

3.6.1. relações de $E_{H}$ e de pS nas amostras de sedimentos do Tietê $\quad 78$

3.7. determinação de metais pesados por espectrofotometria $\begin{array}{ll}\text { de absorção atômica } & 81\end{array}$

3.7.1. deteminação de metais totais nos sedimentos 81

3.7.2. implicações dos resultados de metais pesados nos sedimentos do Tietê

3.7.3. determinação dos metais pesados potencialmente biodisporiveis 95

3.7.4. extração sequencial - métordo de Kersten e Förstner 99

3.7.4.1. estabelecimento das con lições de medida por espectrofotometria de abs ırção atômica 
3.7.4.2. particularidades experimentais sobre o método de extração sequencial adotado

3.7.4.3. discussão dos resultados obtidos por extração sequencial 109

$\begin{array}{lr}\text { 3.8. análise granulométrica } & 115\end{array}$

$\begin{array}{ll}\text { 3.9. análise textural } & 118\end{array}$

$\begin{array}{lr}\text { 3.10. análise de carbono total } & 130\end{array}$

3.11. análise dos ácidos húmicos

133

3.12. discussão geral dos resultados obtidos neste estudo

$\begin{array}{lr}\text { 4. CONCLUSÕES } & 147\end{array}$

5. PROPOSTAS FUTURAS DE ESTUDOS 153

6. REFERÊNCIAS BIBLIOGRÁFICAS 155 


\section{Índice de Figuras}

FIGURA 1: Rio Tietê e os respectivos pontos amostrais : (1) Pirapora; (2) Rasgão; (3)Tecelagem; (4) Rodovia Tietê-Capivari; (5) entrada de Barra

Bonita; (6) margem esquerda de Barra Bonita;(7) ilha de Barra Bonita, (8) ilha ponto 7; (9) jusante de Barra Bonita; (10) Zé do Calção.

FIGURA 2: esquema da draga de Birge-Ekman

FIGURA 3: esquema simplificado do sistema gerador de SAV

FIGURA 4: esquema do método de extração sequencial de Kersten e Förstner, utilizado nas amostras de sedimentos do Tietê

FIGURA 5: fluxogramas correspondentes à extração em ácido diluído e abertura total das amostras de sedimentos do Tietê.

FIGURA 6: curva típica na determinação biamperométrica de sulfeto $\operatorname{com} \mathrm{I}_{2} / \mathrm{l}^{-}$

FIGURA 7: polarograma de uma solução contendo 0,6 ppm de íons sulfeto, em $\mathrm{HOAC/OAC}$

FIGURA 8: polarograma obtido para adições sucessivas de sulfeto, no intervalo de 0,24 a $1,00 \mathrm{ppm}$.

FIGURA 9: verificação da linearidade do eletrodo no intervalo de 0,02 a 0,32 ppm de $S^{2-}$

FIGURA10: verificação da linearidade do eletrodo no intervalo de 0,20 a 2,00 ppm de $S^{2-}$

FIGURA11: comportamento das amostras de sedimentos do Tietê durante o aquecimento por microondas.

FIGURA12: curva de calibração de chumbo em meio de $\mathrm{HCl} 1 \%$.

FIGURA13: curva de calibração de cobre em meio de $\mathrm{HCl} 1 \%$.

FIGURA14: curva de calibração de cádmio em meio de $\mathrm{HCl} 1 \%$.

FIGURA15: curva de calibração de zinco em meio de $\mathrm{HCl} 1 \%$. 
FIGURA16: curva de calibração de níquel em meio de $\mathrm{HCl} 1 \%$.

FIGURA17: curva de calibração de cromo em meio de $\mathrm{HCl} 1 \%$.

FIGURA18: curva de calibração de ferro em meio de $\mathrm{HCl} 1 \%$.

FIGURA19: curva de calibração de manganês em meio de $\mathrm{HCl} 1 \%$.

FIGURA 20: comportamento das amostras de sedimento de lago (certificado)

LKSD 3, durante o aquecimento por microondas.

FIGURA 21: relação percentual de metais potencialmente biodisponiveis entre duas amostras de sedimentos do Tietê.

FIGURA 22: efeito de matriz em curvas de calibração de soluções padrão de chumbo, considerando-se as extrações sequenciais.

FIGURA 23: efeito de matriz em curvas de calibração de soluções padrão de cádmio, considerando-se as extrações sequenciais.

FIGURA 24: efeito de matriz em curvas de calibração de soluções padrão de efeito de matriz em curvas de calibração de soluções padrão de zinco, considerando-se as extrações sequenciais.

FIGURA 25: efeito de matriz em curvas de calibração de soluções padrão de cobre, considerando-se as extrações sequenciais.

FIGURA 26: efeito de matriz em curvas de calibração de soluções padrão de cromo, considerando-se as extrações sequenciais.

FIGURA 27: efeito de matriz em curvas de calibração de soluções padrão de niquel, considerando-se as extrações sequenciais.

FIGURA 28: distribuição dos metais pesados nas diversas fases que compõem o sedimento de Pirapora, segundo o método de extração sequencial de Kersten e Förstner.

FIGURA 29: distribuição dos metais pesados nas diversas fases que compõem o sedimento de Entrada de Barra Bonita, segundo o método de extração sequencial de Kersten e Förstner.

FIGURA 30: imagem ao microscópio eletrônico de varredura (A) textura geral do sedimento de casa do Luís (testemunho de $16-18 \mathrm{~cm}$. de profundidade); (B) espectro obtido por EDX, indicando as associações químicas. 
FIGURA 31: imagem ao microscópio eletrônico de varredura (A) textura geral do sedimento de casa do Luís (testemunho de $10-12 \mathrm{~cm}$. de profundidade); (B) espectro obtido por EDX, indicando as associações quimicas.

FIGURA 32: espectros obtidos por EDX para a amostra de casa do Luís, numa secção de $2-4 \mathrm{~cm}$ de profundidade.

FIGURA 33: espectros obtidos por EDX para a amostra de casa do Luís, numa secção de $10-12 \mathrm{~cm}$ de profundidade.

FIGURA 34: imagem ao microscópio eletrônico de varredura (A) textura geral do sedimento de Rasgão (testemunho de $16-18 \mathrm{~cm}$. de profundidade); (B)espectro obtido por EDX, indicando as associações químicas.

FIGURA 35: imagem ao microscópio eletrônico de varredura (A) textura geral do sedimento de Rasgão (testemunho de $2-4 \mathrm{~cm}$. de profundidade); (B) espectro obtido por EDX, indicando as associações químicas.

FIGURA 36: imagem ao microscópio eletrônico de varredura (A) textura geral do sedimento de Rasgão (testemunho de $2-4 \mathrm{~cm}$. de profundidade); (B) espectro obtido por EDX, indicando as associações químicas.

FIGURA 37: espectros obtidos por EDX para a amostra de Rasgão, numa secção de $2-4 \mathrm{~cm}$ de profundidade.

FIGURA 38: imagem ao microscópio eletrônico de varredura (A) textura geral do sedimento de Barra Bonita; (B) espectro obtido por EDX, indicando as associações químicas.

FIGURA 39: imagem ao microscópio eletrônico de varredura (A) textura geral do sedimento de Barra Bonita; (B) espectro obtido por EDX, indicando as associaçōes químicas.

FIGURA 40: espectros de EDX peira a amostra de Entrada de Barra Bonita.

FIGURA 41: espectro de UV-VIS da amostra de ácido húmico presente no sedimento de casa do Luís (Pirapora)

FIGURA 42: espectro de UV-VIS da amostra de ácido húmico presente no sedimento de Rasgão (Pirapora)

FIGURA 43: espectro de UV-VIS da amostra de ácido húmico presente no 
sedimento de Tecelagem (Pirapora)

FIGURA 44:espectro de UV-VIS da amostra de ácido húmico presente no sedimento de Entrada de Barra Bonita (Pirapora)

FIGURA 45: espectro de UV-VIS da amostra de ácido húmico presente no sedimento de Zé do Calção (Barra Bonita).

FIGURA 46: resultados comparativos entre a fração obtida por extração sequencial e os metais potencialmente biodisponiveis, para a amostra de Pirapora.

\section{Índice de tabelas}

TABELA 1: métodos de extração sequencial de Tessier et al. e de Kersten e Förstner.

TABELA 2: condições analíticas adotadas na determinação dos metais pesados das amostras de sedimento do Tietê, por espectorfotometria de absorção atômica.

TABELA 3: resultados de $\mathrm{E}_{\mathrm{H}}$ e de $\mathrm{pH}$ observados para as amostras do rio Tietê, nos anos de 93, 94 e 95.

TABELA 4: resultados obtidos na adição de íons $S^{2-}$ a uma solução de $I_{2}$

TABELA 5: resultados obtidos de linearidade de $\mathrm{S}^{2-}$, para o intervalo de 0,04 a 0,95 ppm.

TABELA 6: resultados obtidos para o intervalo de 0,02 a 0,32 ppm.

TABELA 7: verificação dos resultados obtidos com o método de adição de padrão para um padrão de sulfeto $(0,32 \mathrm{ppm})$.

TABELA 8: estudo de recuperação de sulfeto em $\mathrm{Zn}(\mathrm{OAc})_{2}$.

TABELA 9: resultados de SAV obtidos para algumas amostras escolhidas do rio Tietê.

TABELA 10: resultados de potenciais redox e correspondentes valores de pS

TABELA 11: programação dos estágios de operação do equipamento de microondas 
TABELA 12: valores dos limites de detecção e limites de determinação dos metais estudados nas amostras de sedimentos.

TABELA 13: resultados obtidos pelo método de microondas e pelo método de bomba de teflon, para as amostras de Pirapora e de Barra Bonita.

TABELA 14: resultados obtidos com os materiais de referência de sedimento lago LKSD-3 (CANMET)

TABELA 15: comparação dos resultados de metais totais das amostras de Pirapora e de Barra Bonita com os resultados de referência global (folhelho médio):

TABELA 16: resultados comparativos de metais pesados do reservatório de Barra Bonita.

TABELA 17: resultados de metais potencialmente biodisponiveis extraidos em $\mathrm{HCl} 0,1 \mathrm{M} \mathrm{e} \mathrm{0,5} \mathrm{M}$

TABELA 18: produtos de solubilidade de alguns sulfetos insolúveis ${ }^{(84)}$ :

TABELA 19: resultados do método de extração sequencial para a amostra de Pirapora

TABELA 20: resultados do método de extração sequencial para a amostra de Barra Bonita:

TABELA 21: resultados da análise granulométrica de sete amostras de sedimentos do rio Tietê

TABELA 22: resultados de carbono, matéria orgânica, $E_{H}$ e SAV para sete amostras selecionadas do rio Tietê.

TABELA 23: resultados das determinações de $\mathrm{C}, \mathrm{H}$ e de $\mathrm{N}$ dos ácidos húmicos extraídos das amostras de sedimentos do Tietê.

TABELA 24: resultados de alguns metais obtidos por tratamento com $\mathrm{HCl}$, em diferentes condições de concentração de ácidos e de temperatura. 


\section{Resumo}

Este tese de doutoramento versa sobre o estudo de estabilidade $\mathrm{e}$ caracterização de amostras de sedimentos de fundo fluviais de um ambiente contaminado, o Rio Tietê, São Paulo, Brasil. O trecho escolhido é considerado altamente contaminado, entre os reservatórios de Pirapora do Bom Jesus e de Barra Bonita, num total de $260 \mathrm{Km}$. Dez estações amostrais foram realizadas. As amostras foram mantidas a $4^{\circ} \mathrm{C}$, na ausência de luz e sob atmosfera de nitrogênio. $O$ estudo de estabilidade, realizado através de medidas mensais de potencial redox e de $\mathrm{pH}$, durante um período de dois anos, indicou que as condições de estocagem utilizadas reproduzem de modo muito satisfatório as condições originais de amostragem. Os valores de potencial redox mostraram que a maioria das amostras são anóxidas. Foi desenvolvida uma metodologia simples e precisa para a determinação de sulfeto ácido volátil (SAV). Os resultados indicam níveis muito elevados no reservatório de Pirapora (450 $\mu \mathrm{mol} / \mathrm{g})$ e muito menores em Barra Bonita $(3,2 \mu \mathrm{mol} / \mathrm{g})$. Foi observada uma forte correlação entre o potencial redox $\left(E_{H}\right)$ e $(p S)(0,9930)$, sugerindo que o par redox $S_{n}{ }^{2-} / S^{0}$ controla o potencial redox no trecho anóxido. Os resultados de carbono orgânico indicam um elevado consumo de matéria orgânica nas condições anóxidas. Ácidos húmicos isolados de algumas amostras indicaram uma relação $\mathrm{C} / \mathrm{H}$ e $\mathrm{C} / \mathrm{N}$ típica de substâncias húmicas de solo. Com relação à presença de metais pesados, foram encontrados níveis elevados em Pirapora, superiores aos de folhelho médio: (Cu, 167 ppm; Cr, 206 ppm; Pb, 259 ppm; Cd, 7,4 ppm; Zn, 573 ppm; Ni, 130 ppm; Fe, 6,3\%; Mn; 167 ppm). Em Barra Bonita os resultados foram semelhantes aos de folhelho médio, não indicando haver contaminação por metais pesados neste ponto. Os resultados percentuais de metais potencialmente biodisponíveis, que indicam contaminação recente, revelaram que Pirapora é uma fonte potencial de contaminação para $\mathrm{Cu}(73 \%)$; $\mathrm{Pb}(41 \%)$; $\mathrm{Cd}(53 \%)$ e $\mathrm{Ni}(81 \%)$. A comparação destes resultados com o método de extração sequencial possibilitam inferir que embora o ambiente seja anóxido e sulfídrico, esses metais 
estão na forma de complexos lábeis e solúveis, como polissulfetos, contrariando as solubilidades de equilíbrio dadas pelos valores de constantes de solubilidade. As análises granulométricas indicaram a presença de uma elevada fração de silte e argila em Pirapora, sugerindo que o sedimento de Pirapora tem um importante papel na redistribuição dos metais à coluna d'água. A microscopia eletrônica de varredura sugeriu contaminação nas amostras de Pirapora por metais pesados. $O$ método de extração sequencial indicou que os metais contaminantes estão associados preferencialmente às frações facilmente redutível, moderadamente redutível, e de sulfetos e matéria orgânica. 


\section{Abstract}

The aim of this doctor thesis is the study of stability and characterization of depth fluvial sediments samples from a contaminated environment, Tietê River, São Paulo, Brazil. The interval choose was the most contaminated one, between Pirapora and Barra Bonita reservoirs, in a distance of $260 \mathrm{Km}$. Ten sampling stations were done. The samples were keep at $4^{\circ} \mathrm{C}$, in the dark and under nitrogen atmosphere, The stability study, carried out under mensal measurements of $E_{H}$ and $\mathrm{pH}$, in the time of 2 years, indicated that sampling conditions adopted reproduced very simillary the original sampling conditions. The $E_{H}$ values showed that the environment is anoxic. It was develop a realibility and simple methodology to the determination of AVS. The results indicates high levels of AVS in the Pirapora reservoir $(450 \mu \mathrm{mol} / \mathrm{g})$ and so smaller in Barra Bonita reservoir $(3,2$ $\mu \mathrm{mol} / \mathrm{g})$. A strong correlation was observed between $E_{H}$ and $\mathrm{pS}(0,9930)$, suggests that the redox pair $S_{n}{ }^{2-} / S^{0}$ controls the redox potential in the anoxic zone of the river. The organic carbon indicates a strongly consumption of the organic matter in anoxic conditions. Some samples of isolated humic acids indicated a tipical $\mathrm{C} / \mathrm{H}$ and $\mathrm{C} / \mathrm{N}$ ratio founded in soils. As despite to heavy metals contamination, high levels were found in Pirapora reservoir, greather as average shale: (Cu, 167 ppm; Cr, 206 ppm; Pb, 259 ppm; Cd, 7,4 ppm; Zn, 573 ppm; Ni, 130 ppm; Mn; 167 ppm; $\mathrm{Fe}, 6,3 \%)$. In the Barra Bonita reservoir, the levels were simmillary as the average shale, and consequently, do not contaminated. The percentual results of bioavailable potentially metals, that represents recent contamination, indicates that Pirapora reservoir is a hot spot to contamination the water column to $\mathrm{Cu}$ $(73 \%) ; \mathrm{Pb}(41 \%) ; \mathrm{Cd}(53 \%)$ e $\mathrm{Ni}(81 \%)$. The comparison between this results and sequential extraction methods one, can be inferred that although the environment are anoxic and sulfidic, heavy metals are as solubles labile polysulphide complexes, in oppositioning to solubility of sulfide salts given as solubility constants theoretical values. The grain size analysis indicates a significant silte and clay fractions in Pirapora, suggests that the sediments play an important role in redistribuition of heavy metals to the water column. The scanning electronic 
microscopy shows a heavy metals contamination in Pirapora sediments. The sequential extraction method indicates that metals contaminants are preferentially distribuited in easily reducible, moderately reducible and sulfidic and organic fractions 


\section{INTRODUÇÃO}

\section{1. aspectos gerais sobre os sedimentos}

Nos ambientes aquáticos, os sedimentos constituem uma fase mineralógica com partículas de tamanhos, formas e composição química distintas. Esses materiais, em sua maioria, são depositados nos rios, nos lagos ou mesmo no fundo dos oceanos durante muitos anos. Processos biogeoquímicos controlam o acúmulo e a redistribuição de suas espécies químicas para a biota aquática, tais como reações de precipitação e transformações biológicas, caracterizando o sedimento como uma parte integrante do sistema natural ${ }^{(1,2)}$. Desde os tempos mais remotos, autores como Hutchinson et al. ${ }^{(3)}$ e Züllig ${ }^{(4)}$ já apontavam o importante papel que os sedimentos desempenham nos complexos processos de interações hidroquímicas que ocorrem nos rios e lagos.

Já há algum tempo, os mecanismos naturais de formação dos sedimentos vêm sendo intensamente alterados pela ação do homem. A erosão do solo causada pela construção de prédios e rodovias, bem como o lançamento direto de efluentes industriais e municipais propiciam um perfil completamente diferente à dinâmica de sedimentação encontrada nos ambientes naturais, não perturbados ${ }^{(1)}$. As quantidades elevadas de matéria orgânica não degradada (de origem autóctone) geradas na bacia de drenagem, os metais pesados, dentre muitos outros agentes danosos ao equilibrio natural, causam uma intensa alteração na vida aquática. Os metais pesados representam uma preocupação especial nesse sentido, pois não são biodegradados, e portanto podem se acumular na biota aquática em niveis significativamente elevados ${ }^{(5-8)}$.

Segundo Förstner ${ }^{(9)}$, os sedimentos de fundo desempenham o papel mais importante no esquema de poluição dos rios por metais pesados. Eles refletem a qualidade corrente do sistema aquático e podem ser usados para detectar a presença de contamiriantes que não permanecem solúveis após o seu lançamento em águas superficiais. Mais do que isso, os sedimentos agem como carreadores e possiveis fontes de poluição, pois os metais pesados não são 
permanentemente fixados por eles e podem ser redispostos para a água por mudanças nas condições ambientais tais como $\mathrm{pH}$, potencial redox ou a presença de quelantes orgânicos ${ }^{(10)}$. As propriedades de acúmulo e de redisposição de espécies nos sedimentos os qualificam como de extrema importância em estudos de impacto ambiental, pois registram em carater mais permanente os efeitos de contaminação $^{(9)}$. Mozeto ${ }^{(11)}$, referindo-se aos importantes trabalhos de Mortimer ${ }^{(12-}$ 13), aponta para a importância que o sedimento representa no intercâmbio de nutrientes e outras substâncias com a coluna d'água. Ele diz : "Um bom tempo se passou para que as descobertas e os ensinamentos básicos de Mortimer fossem aplicados e extendidos para se entender que o compartimento sedimento não é só um sítio integrador dos "produtos" gerados na coluna d'água e daqueles com origem nas bacias hidrográficas, mas um compartimento que reprocessa esses materiais e que pode alterar a qualidade da coluna d'água". Especialmente em ambientes onde a coluna d'água possui pouca profundidade, a taxa de intercâmbio de espécies solúveis pode até dobrar devido a ação dos ventos que provoca a ressuspensão de sedimentos ${ }^{(14)}$.

\section{2. metais pesados nos sedimentos}

Há pelo menos 3 décadas, inúmeros esforços têm sido realizados no sentido de se esclarecer a distribuição de metais pesados nos sedimentos, pois a participação deste compartimento ambiental é de carater fundamental na qualidade de um ambiente aquático. Sabe-se que esta distribuição ocorre entre fases, não totalmente caracterizadas, tais como carbonatos, óxidos de ferro e manganês, matéria orgânica, su'fetos, detritos e argilas ${ }^{(10)}$. Dependendo do grau de impacto que o ambiente aquático esteja sofrendo, mudanças nas condições redox, no $\mathrm{pH}$ e até mesmo no regime de ressuspensão do sedimento de fundo podem propiciar uma diferente disposição desses metais para a biota ${ }^{(10)}$.

Ambientes como as baías, que naturalmente não oferecem condições de escoamento de água, caso sejám contaminadas, precisam ter seus sedimentos removidos por dragagem de furdo. No entanto, sedimentos de outros ambientes 
tais como estuários, rios e lagos não requerem dragagem, mas têm de ser cuidadosamente acompanhados, a fim de se avaliar os efeitos dos metais no ecossistema e com isso sugerir planos apropriados para remediação e manejo ${ }^{(1)}$. No caso dos rios, é verificado que a concentração de metais contaminantes nos sedimentos tendem a diminuir conforme se afasta das fontes de poluição ${ }^{(15)}$

Os zstudos relacionados à contaminação de sedimentos por metais pesados tem avançado sensivelmente nos últimos anos. Parece haver um consenso de que a determinação pura e simples da concentracão total de um determinado metal num sedimento, modelo de interpretação muito utilizado no passado, não oferece nenhuma informação adicional além da taxa de estocagem deste metal. De fato, tal abordagem não propicia conhecimento algum a respeito da mobilidade deste metal ${ }^{(9)}$, ou mesmo de sua disponibilidade biológica ${ }^{(10)}$. Isto é plenamente corroborado por Kersten e Förstner, os quais consideram que a tendência de um determinado elemento ser acumulado por organismos depende em particular da capacidade do sistema água/sedimento de dispor elementos traço removidos da solução por processos bióticos e abióticos ${ }^{(16)}$. Os componentes sólidos governam os níveis dissolvidos destes elementos via reações de precipitação/dissolução e sorção/dessorção. Consequentemente, identificar "espécies" tende a ser muito mais útil sob o ponto de vista de avaliação ambiental que determinar a concentração total deste elemento.

Esta moderna abordagem resulta de um reconhecimento de que a biogeoquímica e especialmente a toxicidade de um dado poluente que adentra a um compartimento ambiental é determinada por sua forma de ligação específica e reatividade, preferencialmente, do que pela sua taxa de acumulação. De acordo com Aualitia e Pickering ${ }^{(17)}$ hoje está significativamente reconhecido que somente uma fração do conteúdo total de metais em materiais contaminados (solos, sedimentos e dejeitos) é "lábil", "movel" ou "biologicamente disponivel'.

Historicamente, a determinação analítica da distribuição de metais dentro dessas frações tem sido abordada por extrações seletivas envolvendo um ou mais reagentes. Vale ressaitar que os resultados obtidos são operacionalmente definidos, e que portanto são válidos em condições bem estabelecidas. 
Nos esquemas de especiação, o termo espécie não se refere a uma forma quimica definida, mas simplesmente se baseia em um conceito operacional relacionado com o procedimento adotado e o reagente utilizado .

Segundo Fiedler ${ }^{(10)}$, a fim de se ter uma interpretação correta do "enriquecimento" de metais em sedimentos contaminados, deve distinguir-se entre os processos de origem natural : geológicos, mineralógicos, ridrológicos e biológicos, daqueles que tem como origem a ação do homem. Com relação a isto, entende-se que um sedimento é geralmente formado por fases sólidas de elementos majoritários: metais (p.e. $\mathrm{Fe}, \mathrm{Al}, \mathrm{Ca}, \mathrm{Mn}$ ), não metais ( $\mathrm{C}, \mathrm{S}, \mathrm{Si}$ e $\mathrm{P}$ ) e ainda metais traço $(\mathrm{Cd}, \mathrm{Cr}, \mathrm{Cu}, \mathrm{Pb}, \mathrm{Zn}, \mathrm{Ni}$, etc), precipitados como fases sólidas discretas, tais como $\mathrm{Cu}_{2}(\mathrm{OH})_{2} \mathrm{CO}_{3}, \mathrm{~Pb}_{3}\left(\mathrm{PO}_{4}\right)_{2}, \mathrm{~Pb}_{5}\left(\mathrm{PO}_{4}\right)_{3} \mathrm{Cl}, \quad \mathrm{Zn}_{5}(\mathrm{OH})_{6}\left(\mathrm{CO}_{3}\right)_{2}$, $\mathrm{Zn}_{3}\left(\mathrm{PO}_{4}\right)_{2} \cdot \mathrm{H}_{2} \mathrm{O}, \mathrm{ZnSiO}_{4}$, conforme descrito por Jenne et al. ${ }^{(18)}$. Estes metais podem estar presentes em altas concentrações, devidos a processos diagenéticos ou por contaminação, já que possuem a tendência de coprecipitar e adsorverem-se no no material particulado que sofre sedimentação. Tal material, em águas naturais, consiste predominantemente de detritos orgânicos, coloides, células vivas (bactérias e algas) e sólidos inorgânicos, tais como: óxidos e hidróxidos de metais, carbonatos e argilas.

As misturas complexas de fragmentos minerais e produtos de decomposição de diferentes materiais, conforme já foi salientado, possuem composição química e tamanho físico variável. Förstner e Salomons ('), dentre outros autores, sugerem que nas análises de metais em sedimentos se leve em conta somente a fração do sedimento $<63 \mu \mathrm{m}$. Esta fração é a que corresponde ao material mais fino do sedimento (representado como silte e argila), além de ser também a que apresenta o conteúdo de metais mais elevado de todas as frações granulométricas maiores. Isto é decorrência do fato que nestes pequeninos grãos, pode-se encontrar grandes quantidades de óxidos de ferro, de manganês e matéria orgânica, reconhecidamente os materiais que desenvolvem a maior ação de superfície no sedimento ${ }^{\text {() }}$.

$\mathrm{Na}$ fração seguinte (acima de $63 \mu \mathrm{m}$ ), que é considerada essencialmente areia, nota-se que o conteúdo de metais decresce linearmente. Stumm e 
Morgan $^{(19)}$ explicam que as as frações mais finas, apresentam uma maior área específica, favorecendo assim os processos desenvolvidos na interface sólidolíquido, tais como adsorção, precipitação, interação com a matéria orgânica, etc.

Segundo Gibbs $^{(20)}$, os metais pesados se incorporam a um sedimento seguindo certos modelos, a saber:

(a) Absorção na superfície do sedimento por íons trocáveis.

(b) Coprecipitação com óxidos de ferro hidratado e óxidos de manganês.

(c) Complexação com moléculas crgânicas e incorporação em materiais biológicos.

(d) Incorporação na estrutura cristalina.

A distribuição acima sugerida por Gibbs, confirma os avanços na determinação de metais, mostrando que há mais de 30 anos já se pensava num modelo de especiação de metais pesados em sedimentos e que somente hoje vem se firmando como metodologia analítica de extrema valia no campo da Biogeoquímica. A discussão sobre a especiação química de metais pesados em sedimentos será apresentada no item seguinte.

\section{3. especiação química de metais em sedimentos}

Como já foi abordado anteriormente, os estudos de especiação se baseiam em aproximações que simulam mudanças nos parâmetros considerados fundamentais nos fenômenos de mobilização e retenção de espécies no meio natural ${ }^{(10)}$. Os procedimentos de especiação utilizados incluem, dentre outros, diálise, acidificação progressiva e principalmente extração sequencial. Estritamente falando, a especiação química de metais pesados em sedimentos é 
o resultado do tratamento de uma determinada amostra de sedimento com uma série de reagentes, cada vez mais fortes, sob condições específicas.

Apesar do grande interesse que o tema desperta, os resultados obtidos em protocolos de extração sequencial são questionados por alguns autores: Nirel e Morel $^{(19)}$ consideram que as extrações sequenciais não devem ser extrapoladas para processos ecotoxicológicos, pois as condições de laboratório, enérgicas e de cinética rápida, não reproduzem as condições naturais, que são brandas e de cinética lenta. No entanto, tais considerações não são um consenso geral, visto que outros autores verificaram que a quantificação dos metais nas frações obtidas a partir de extração sequencial, proporcionam o melhor prognóstico do metal potencialmente removivel ${ }^{(22-24)}$. Kersten e Förstner ${ }^{(16)}$ demonstraram que os problemas apontados às limitações da extração sequencial são de fato produzidos por manuseio impróprio das amostras durante a etapa de extração.

Outros problemas apontados aos métodos de extração são a falta de seletividade dos reagentes e a redistribuição dos metais durante as extrações ${ }^{(25)}$. Some-se a este quadro a garantia de preservação das amostras, a fim de se manter uma condição de confiabilidade nos resultados obtidos. ${ }^{(16-26)}$ Estes problemas têm dificultado o estabelecimento de um método de ampla aceitação e apesar das dificuldades apontadas pára se estabelecer um método padrão, muito têm-se buscado neste sentido. Uma das propostas, é a de se preparar materiais de referência que possam trazer uma padronização de procedimentos. Esta têm sido uma das metas de Fiedler e colaboradores, através de um exaustivo trabalho junto ao Community Bureau of Reference $(B C R)^{(27)}$

\section{4. métodos de extração sequencial}

Uma série de metodologias analíticas de extração sequencial de metais pesados em sedimentos vem sendo publicadas nas últimas duas décadas. Algumas revisões apresentam o resumo dos principais métodos de extração. ${ }^{\text {(28-33) }}$ Pode-se observar que, dentre iss métodos existentes, aqueles que apresentam uma maior aceitação perant’ a comunidade científica são os métodos 
desenvolvidos por Tessier et al. ${ }^{(34)}$ e Kersten e Förstner ${ }^{(35)}$. Diante da significativa importância que esses dois procedimentos têm representado nos estudos de metais em sedimentos, discutiremos detalhadamente cada um deles. A tabela 1 apresenta de forma comparativa as frações obtidas em cada etapa de extração por estes dois métodos:

TABELA 1 - Métodos de extração sequencial de Tessier et al. e de Kersten e Förstner.

\begin{tabular}{|c|c|c|}
\hline \multirow{2}{*}{ fração obtida } & \multicolumn{2}{|c|}{ meios de extração } \\
\hline & método de Tessier et al. & método de Kersten e Förstner \\
\hline trocável & $\mathbf{M g C l}_{2}, \mathbf{1 M}$. & $\mathrm{NH}_{4} \mathrm{OAc}, 1 \mathrm{M}$. \\
\hline carbonatos & NaOAc, 1M, pH 5 (HOAc) & NaOAc, 1M., pH 5 (HOAc) \\
\hline facilmente redutiveis & - & $\mathrm{NH}_{2} \mathrm{OH} . \mathrm{HCl} 0,1 \mathrm{M}, \mathrm{pH} 2\left(\mathrm{HNO}_{3}\right)$ \\
\hline dxidos de Fe e Mn & $\begin{array}{c}\mathrm{NH}_{2} \mathrm{OH} . \mathrm{HCl}(0,04 \mathrm{M} .) \\
\text { HOAc } 25 \%, 9^{\circ} \mathrm{C}\end{array}$ & \\
\hline $\begin{array}{l}\text { moderadamente } \\
\text { redutiveis }\end{array}$ & 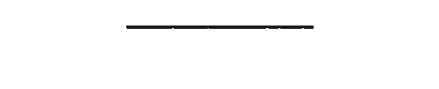 & $\begin{array}{l}\text { tampão oxalato } \\
0,1 \mathrm{M}(\mathbf{p H} 3)\end{array}$ \\
\hline $\begin{array}{l}\text { matéria orgânica e } \\
\text { sulfetos }\end{array}$ & $\begin{array}{c}\mathrm{H}_{2} \mathrm{O}_{2} 30 \%, \mathrm{HNO}_{3}(\mathrm{pH} 2) \\
85^{\circ} \mathrm{C}, \mathrm{NH}_{4} \text { OAc } 1 \mathrm{M}\left(\mathrm{HNO}_{3}\right)\end{array}$ & $\begin{array}{c}\mathrm{H}_{2} \mathrm{O}_{2} 30 \%, \mathrm{HNO}_{3} 0,02 \mathrm{M}(\mathrm{pH} 2) \\
\quad 85^{\circ} \mathrm{C} ; \mathrm{NH}_{4} \mathrm{OAc}\left(\mathrm{HNO}_{3} 6 \%\right)\end{array}$ \\
\hline residual & $\mathrm{HF}, \mathrm{HClO}_{4}$ quente & $\mathrm{HNO}_{3}$ quente \\
\hline
\end{tabular}


Embora os dois métodos apresentem algumas semelhanças entre si, os aspectos que os diferem são fundalmente importantes, o que torna conveniente uma discussão individual de cada um deles. $O$ procedimento de Tessier et al. envolve cinco etapas de extração, a saber:

a - Fração trocável: Ao haver contato da amostra com uma solução de elevada força iônica, processos superficiais de sorção/dessorção envolvendo interações de troca iônica, podem ser alterados. Dessa forma, a então chamada fração

trocável do metal pode ser liberada. Usa-se nesta etapa como reagente de extração uma solução de $\mathrm{MgCl}_{2} 1 \mathrm{M}$.

b - Fração ligada a carbonatos: A fração de metais ligada a carbonatos presentes numa amostra pode, segundo o método proposto, ser liberada seletivamente mediante uma variação de $\mathrm{pH}$ da própria amostra, com uma solução de extração levemente ácida (tampão acetato, pH 5). Este procedimento visa simular uma possível liberação de metais após um abaixamento de pH em águas naturais.

c - Fração ligada a óxidos de ferro e manganês: Óxidos de ferro e manganês agem como material coesivo entre as partículas, ou mesmo como uma camada de cobertura; nos seus nódulos uma certa fração de metais pode ser liberada em condições anóxidas, ou seja, baixos valores de potencial redox. Isto se deve ao fato de que, nestas condiçōes, os óxidos são termodinamicamente instáveis e podem assim liberar os metais a eles associados.

d - Fração ligada á matéria orgânica: Os metais podem ainda se associar a várias formas de matéria orgânica, principalmente a complexantes naturais, como ácido húmico e ácido fúlvico. Uma tratamento oxidante pode, consequentemente, liberar os metais presentes nesta fração. 
e - Fração residual: A fração residual deve conter principalmente minerais primários e secundários, que aprisionam os metais dentro de suas estruturas cristalinas, e portanto não se espera que esta fração contribua para a presença desses metais em solução.

Deve-se considerar que, embora o método descrito acima tenha (e tem) sido amplamente utilizado por vários grupos, há contestações com relação à validade de seus resultados. Kheboian e Bauer ${ }^{(25)}$, utilizando modelos sintéticos de sedimentos, com fases geoquímicas rigorosamente estabelecidas, encontraram resultados significativamente diferentes entre este método $e$ os resultados obtidos por técnicas especiais como difração de raio- $\mathrm{X}$ e microscopia eletrônica de varredııra. Como já foi mencionado anteriormente, estes autores atribuem as diferenças encontradas principalmente ao fenômeno de redistribuição dos metais durante as etapas de extração.

Considerando que os problemas operacionais apontados ao método de Tessier et al., se devam principalmente ao manuseio das amostras, Kersten e Förstner ${ }^{(35)}$ sugeriram um método de extração sequencial conduzido em condições de atmosfera livre de $\mathrm{O}_{2}\left(\mathrm{~N}_{2}\right.$ ou $\mathrm{Ar}$ ). Uma preocupação importante verificada no método de Kersten e Förstner, e que não é encontrada nos outros métodos de extração, é com relação à integridade das amostras. ${ }^{(35)}$ Pode-se observar que a totalidade dos métodos desenvolvidos anteriormente ao método em questão, mencionam uma etapa da secagem da amostra antes do inicio das extrações. Isto provoca uma modificação irreversível na condição original de associação dos metais na amostra, levando esses metais a condições altamente instáveis e reativas (elevada entropia). ${ }^{(36)}$

O método de Kersten e Förstner, apresentado esquematicamente na tabela 1 , resulta em seis frações, a saber:

a - Fração trocável: Conforme é apontado pelos autores, a dupla camada elétrica estabelecida na superficie do sedimento é controlada principalmente pelo $\mathrm{pH}$ da 
superficie e pela força iônica do meio ${ }^{(16)}$. Dessa forma, sais neutros como $\mathrm{MgCl}_{2}$, $\mathrm{NaNO}_{3}$ ou mesmo $\mathrm{NH}_{4} \mathrm{OAc}$ são comumente escolhidos para extrair metais, por deslocamento dos sítios de adsorção. Um estudo sistemático sobre a eficiência de certos sais na extração de metais mostrou que $\mathrm{NH}_{4} \mathrm{OAc}$ foi totalmente eficiente na extração de $\mathrm{Zn}, \mathrm{Cu}$ e $\mathrm{Mn}$, enquanto que os outros apresentaram resultarlos sensivelmente menores. ${ }^{(34)}$ No entanto, Tessier e colaboradores utilizam $\mathrm{MgCl}_{2}$ nesta etapa.

b - Fração ligada a carbonatos: O uso de tampão acetato tem sido incorporado em praticamente todos os esquemas de extração. Apesar da eficiência de extração verificada nos experimentos, são encontrados também elevados niveis de ferro e manganês nas soluções de extração. Esses efeitos são, segundo estes autores, estritamente dependentes da preservação das condições redox durante o procedimento analítico, devido à reatividade das fases Fe/Mn (II), o que sugere um controle rigoroso nesta etapa de extração. ${ }^{(16)}$

c - Fração dos facilmente redutiveis: Os autores consideram útil nos estudos ambientais que haja uma diferenciação entre óxidos cristalinos de $\mathrm{Fe} / \mathrm{Mn}$ e oxidratos não cristalinos. Nesse sentido, uma extração com ênfase na fração de óxidos facilmente redutíveis reflete melhor o comportamento dos metais. $O$ método de Tessier et al. não considera relevante tal diferenciação.

d - Fração moderadamente reclutiveis: A fração moderadaınente redutiveis é, na realidade, uma adaptação da "técnica padrão" utilizada há muito por pesquisadores de solos na caracterização da cristalinidade de óxidos de ferro e alumínio, importante parâmetro de classificação de solos ${ }^{(16)}$. Esta extração baseiase no princípio que os óxidos amorfos de ferro sofrem ataque completo por uma solução de ácido oxálico 0,1 M amponada com oxalato de amônio (para pH 3), com agitação e ausência de luz. Na ausência do efeito catalítico da luz, esse 
reagente não dissolve óxidos de ferro cristalinos. ${ }^{(37)}$

e - Fração residual: A fração residual não è considerada importante nos processos de transformações diagenéticas recentes, mas é considerada útil pois serve como um balanço final na soma das quantidades individuais de cada elemento. Deve-se considerar que o método de Kersten e Förstner apresenta cuidados extremamente importantes, apontados por outros autores. Engler et al.

(39) consideram que a integridade anaeróbica de uma amostra deve ser mantida durante a sua manipulação e nas extrações, a fim de evitar o contato com o oxigênio do ar. Os efeitos de várias técnicas dt; preservação (estocagem in natura, congelamento, refrigeração, secagem em forno) em amostras anóxidas e sub-óxidas têm sido relatados de forma detalhada na literatura ${ }^{(16-35,36)}$.

\section{5. extração parcial de metais pesados com HCl diluído}

Além dos métodos tradicionais de extração sequencial, que sugerem a provável associação dos metais no sedimento e a consequente "disponibilidade", "labilidade" ou "mobilidade" dos referidos metais, existe ainda uma outra proposta de estudo, que inclue o tratamento da amostra com ácido diluído. Este procedimento consiste em tratar uma determinada amostra de sedimento com ácido clorídrico diluído ( $\mathrm{HCl} \mathrm{0,1} \mathrm{a} 1 \mathrm{M}$ ) à temperatura ambiente, sob agitação, por um período pré-estabelecido (geralmente 2 hs.). Tal procedimento é considerado como um primeiro estágio de reconhecimento de poluição por metais, possibilitando assim estimar-se os metais "potencialmente biodisponíveis" ${ }^{(40,41)}$. A idéia de se relacionar o resultado desta extraçāo com a biodisponibilidade do metal vem dos importantes trabalhos de Luoma e Bryan ${ }^{(42)}$ e Luoma ${ }^{(43)}$, que verificaram uma correlação significativa entre os níveis de metais extraídos com os níveis acumulados por organismos em bioensaios.

Sob o ponto de vista geoquímico, Kersten e Forstner ${ }^{(16)}$ consideram que, 
na realidade, o tratamento ácido libera os metais associados às fases consideradas instáveis nos sedimentos (matéria orgânica, argilas, óxidos hidratados e carbonatos), sem causar um ataque significativo a quaisquer fragmentos cristalinos presentes na amostra. Fiszman et al. ${ }^{(44)}$ submeteram amostras de sedimento tarto à extração ácida, quanto a um método de extração sequencial de 4 etapas, encontrando melhores resultados com o primeiro método. Malo $^{(40)}$ estudou diversas amostras de sedimentos com $\mathrm{HCl}$ diluído, e designou esta metodologia como sendo uma extração parcial dos metais, verificando também resultados significativamente satisfatórios. Pelo menos dois importantes protocolos da EPA (Envircnmental Proteccion Agency) recomendam esta extração para fins de reconhecimento de contaminação recente. ${ }^{(45,46)}$ A fração de metais extraída em $\mathrm{HCl}$ é denominada como sendo "weakly bound" (metais fracamente ligados), e os metais resultantes do ataque ácido enérgico, $\mathrm{HF} / \mathrm{HNO}_{3} / \mathrm{HCl}$, definem uma outra fração, denominada "strongly bound" (metais fortemente ligados).

\section{6. outras metodologias utilizadas na caracterização de sedimentos}

Até aqui, as consideraçōes sobre a qualidade de sedimentos versaram principalmente sobre uma importante questão que é a presença de metais contaminantes e sua possivel distribuição nas diversas fases que compõem o sedimento. De fato, os sedimentos sāo uma fonte potencial de informaçōes, pois constitue-se num compartimento ambiental que participa ativamente nos processos biogeoquímicos. O reconhecimento disto está no fato de que já há alguns anos os sedimentos vem sendo incluídos em programas oficiais de monitoramento ambiental ${ }^{(47,48)}$.

O conjunto das análises físico-químicas realizadas em sedimentos permite obter mais informações sobre o ambiente estudado.

Chamamos de "protocolo" o conjunto de ações concatenadas que possam 
dar subsídio a um trabalho coordenado em termos de planejamento de amostragem, desenvolvimento analítico e seus resultados. Estabelecer este protocolo exige que os procedimentos sejam rigorosamente estudados e detalhadamente descritos, a fim de propiciar uma possibilidade de intercomparação de metodologias, sempre que necessário.

\subsubsection{Planejamento de trabalho}

Com relação ao planejamento de trabalho, deve-se realizar um levantamento dos estudos mais importantes desenvolvidos na região e com isso buscar um inventário de dados que sejam relevantes aos objetivos do projeto. Deve-se levar em conta a escolha adequada das estações de amostragem além de outros importantes fatores que não serão discutidos aqui, tais como: custos, levantamento dos dados, etc. Pode-se consultar Mudrock e McNight ${ }^{(1)}$ para se ter uma boa idéia sobre este assunto.

\subsection{2. amostragem}

O objetivo de um bom programa de amostragem de sedimentos é o de proceder de tal forma que se possa manter a representatividade do material o tanto quanto possivel. Após os sedimentos terem sido coletados, o material resultante deve ser manuseado e processado de forma apropriada. Deve haver pequena ou se possível nenhuma perturbação durante atividades de campo e no transporte, antes de chegar ao laboratório. Segundo Mudrock e Bourbonniere ${ }^{(49)}$, o manuseio, a preparação e a estocagem das amostras são uma etapa chave no bom andamento do projeto, pois desde que bem conduzidas, propiciam resultados mais fidedignos sobre o ambiente estudado. 


\subsection{3 procedimentos e resultados analíticos}

O item anterior chama a atenção para a relação de representatividade da amostra nos resultados. Deve-se ter em mente que os resultados analíticos, mesmo sendo obtidos com a mais satisfatória confiabilidade, podem ficar comprometidos com o preparo e o manuseio inadequado das amostras. Por exemplo, contaminação, perdas da espécie de interesse ou ainda a mudança de certos componentes de uma dada amostra através de: evaporação, oxidação, etc. podem ser considerados fatores que comprometem significativamente a sua integridade ${ }^{(50)}$.

A literatura não se apresenta satisfatória o basłante com relação a um maior detalhamento sobre procedimentos apropriados de manuseio de amostras de sedimentos. Geralmente são adotados procedimentos próprios, conforme cada necessidade específica ${ }^{(1)}$.

No caso de ambientes contaminados, geralmente com características subóxidas ou anóxidas, suas amostras são extremamente instáveis sob o contexto físico e biológico, o que causa problemas nos estudos voltados à especiação de metais pesados. ${ }^{(36)}$

Tendo-se estabelecido as rielhores condições de amostragem, de manuseio, o número e tipo de pontos a serem amostrados, os tipos de frascos, amostradores e demais equipamentos, dentre outros detalhes, deve-se estabelecer as análises a serem realizadas. Serão apresentadas a seguir, as principais metodologias utilizadas na caracterização de amostras de sedimentos. Dentre as principais metodologia:s, podem ser apontadas:

- determinação do grau de pres ’rvação das amostras.

- determinação do potencial redox.

- determinação do $\mathrm{pH}$. 
- determinação de metais pesados e suas "formas" (p.e., por Espectrofotometria de Absorção Atômica).

- determinação de Sulfeto Ácido Volátil (SAV).

- análise granulométrica.

- determinação de carbono total

- análise textural através de Microscopia Eletrônica de Varredura (MEV)

- isolamento e caracterização de ácidos húmicos

Ao nosso ver, a partir do estabelecimento do protocolo de procedimentos sugerido acima, muito pode-se conhecer a respeito da participação dos sedimentos nos ambientes contaminados. Passaremos a discutir detalhadamente cada metodologia, visando com isso esclarecer a importância que cada uma representa no estudo de sedimentos.

\section{7. preservação das amostras}

Assim como foi discutido no item anterior, a preservação das amostras é um procedimento que deve ser tratado possuindo fundamental importância na garantia da qualidade dos resultados analíticos. O manuseio impróprio de uma amostra recém-coletada, como exposição ao oxigênio do ar, à luz e ao calor pode modificar completamente as suas características originais ${ }^{(50)}$. Nesse sentido, as coletas de amostras devem ser conduzidas o mais rapidamente possivel, bem como se evitar longos períodos de estocagem.

Amostras que exigem cuidados especiais de manuseio devem ser mantidas 
em atmosfera controlada, livre de oxigênio, que pode ser obtida em compartimentos especiais, denominados "glove box", ou ainda em sacos plásticos, "glove bags".

Ainda com relação ao manuseio de amostras de sedimentos, Kersten e Förstner ${ }^{(16)}$ consideram que submetê-las a alguns tipos de tratamento como congelamento, secagem e peneiramento causam modificaçōes irreversiveis nas suas condições originais.

A preservação de uma amostra pode ser acompanhada através de medidas da variação do seu valor de $\mathrm{pH}$ e de $\mathrm{E}_{\mathrm{H}}$ ( potencial redox). Pode-se realizar estas medidas in situ, e compará-las com os valores medidos no laboratório. Esta é uma propnsta sugerida neste trabalho em carater inédito, visto que não há relatos sobre tal procedimento.

\section{8. medida de potencial redox}

As medidas de potenciais redox em amostras de sedimentos devem ser consideradas de importância significativa na avaliação da qualidade ambiental, pois indicam de forma satisfatória a condição redox em que o meio se encontra, principalmente em termos de estagnação ${ }^{(12,13)}$. No entanto, a literatura recomenda uma certa cautela na interpretação dos valores de $E_{H}$.

Segundo as considerações de Morris e Stumm ${ }^{(51)}$, medidas de potenciais redox em ambientes de águas naturais envolvem uma complexa teoria e problemas práticos, em oposição à aparente simplicidade da medida eletroquiímica. Embora os sistemas aquosos contenham oxigênio ou agentes oxidantes, que apresentarão valores positivos de $E_{H}$ e agentes redutores que apresentarão valores negativos de $E_{H}$, uma interṕretação quantitativa detalhada destes potenciais é, segundo estes autores, injustificada na maioria dos casos. Isto se deve ao fato de que a maioria dos potenciais medidos em águas naturais 
representam uma somatória de potenciais, e não o valor de uma única espécie química.

A medida de $E_{H}$ consiste na leitura do potencial acusado por um eletrodo indicador inerte (geralmente de platina), versus um eletrodo de referência (calomelanos ou $\mathrm{Ag} / \mathrm{AgCl}$ ), inseridos diretamente na amostra. I) procedimento em campo implica em coletar uma quantidade do material com um coletor apropriado (p.e. uma draga), içar o equipamento para o barco e adaptar rapidamente o conjunto de leitura. Os eletrodos devem ser introduzidos cerca de 5 centímetros no sedimento e a leitura final pode ser realizada após alguns minutos ${ }^{(1)}$.

Whitfield ${ }^{(52)}$ realizou medidas de $E_{H}$ utilizando dois t:letrodos de platina dispostos lado a lado e um eletrodo de referência de calomelanos, a fim de determinar a reprodutibilidade das leituras de $\mathrm{E}_{\mathrm{H}}$. Os valores medidos por estes dois eletrodos diferiram numa faixa de 10 a $30 \mathrm{mV}$, devido a uma série de interferências que ocorrem nas superfícies dos eletrodos, tais como adsorção de íons sulfeto e de matéria orgânica, que ocorrem quando se mantem o eletrodo indicador num tempo excessivamente longo em amostras ricas em sulfeto. Do mesmo modo, foram verificados os mesmos problemas no eletrodo de referência. Este autor observou que quando as leituras de $E_{H}$ foram realizadas com um eletrodo de referência chamado por ele de "junção remota", isto é, algo semelhante a uma ponte salina, as leituras foram estáveis e os resultados reprodutiveis, mesmo para as amostras mais anóxidas.

Os eletrodos de platina são os mais comumente utilizados nas medidas de $E_{H}$. No entanto, devido à facilidade que este material apresenta na adsorção de espécies, existem eletrodos de $E_{H}$ fabricados com outros materiais, como grafite $e$ ouro. No caso de amostras de solos e suspensões aquosas, alguns autores utilizaram para medir $E_{H} u m$ eletrodo de grafite recoberto com cera ${ }^{(53,54)}$.

Não é possivel calibrar-se um eletrodo de $E_{H}$ dentro de uma faixa de potenciais redox, como é feito para os eletrodos de $\mathrm{pH}$. Ao invés disso, são utilizadas soluções padrão que apresentem estabilidade química e potenciais 
redox bem conhecidos para o eletrodo indicador em questão, para se testar a resposta do eletrodo na temperatura da medida.

A solução mais utilizada em medidas de $\mathrm{E}_{\mathrm{H}}$ é a conhecida como "solução de ZoBell"(55). Trata-se de uma solução equimolar de ferricianeto de potássio e ferrocianeto de potássio $(0,003 \mathrm{M})$, em meio de $\mathrm{KCl} \mathrm{0,1} \mathrm{M}$, que mantem um elevado grau de preservação na ausência de luz e calor. Nordstrom determinou rigorosamente o potencial desta solução em função da temperatura ${ }^{(56)}$. Uma boa concordância foi verificada para os valores de $\mathrm{E}_{H}$ medidos com o par de eletrodos na solução de ZoBell e os valores calculados das constantes de estabilidade, de 8 a $85^{\circ} \mathrm{C}$. O potencial da solução dəz ZoBell com o eletrodo indicador (vs. ENH), em função da temperatura, pode ser calculado como segue ${ }^{(57)}$ :

$$
E_{H,} V=0,428-0,0022(T-25) \quad \text { (eq. 1.1) }
$$

onde $\mathrm{T}=$ temperatura da solução, ${ }^{\circ} \mathrm{C}$. A estabilidade da solução de ZoBell é atingida conservando-a ao abrigo da luz e do calor $\left(4^{\circ} \mathrm{C}\right)$. Uma outra solução que pode ser utilizada para eletrodos de $E_{H}$ é a chamada solução de $\operatorname{Light}^{(58)}$, preparada com sulfato ferroso amoniacal e sulfato férrico amoniacal $(0,1 \mathrm{M})$, em meio de $\mathrm{H}_{2} \mathrm{SO}_{4} 1 \mathrm{M}$.

Antes de se realizar a medida de $E_{H}$ de uma amostra de sedimento, devese proceder à medida da solução padrão e comparar com o valor obtido com 0 da equação acima, ou verificar uma tabela de valores de $\mathrm{E}_{\mathrm{H}}$. Caso verifique-se um desvio superior a $10 \mathrm{mV}$, deve-se? realizar a limpeza do eletrodo de platina. Isso geralmente é feito com papel de (:arborundum ou pó de joalheiro. Após a limpeza, lavar com água destilada e rea izar nova leitura. Verificando-se ainda desvios significativos, procede-se a limpeza com ácidos. Os tratamentos alternativos incluem 1 a 2 minutos em água régia a $70^{\circ} \mathrm{C}, 5$ minutos em $\mathrm{HNO}_{3} 6 \mathrm{M}$ e água em ebulição, ou ainda solução de sılffocrômica seguida de $\mathrm{HCl}$ 6M e lavagem com água. 
Embora os valores de $E_{H}$ obtidos de amostras reais, na maioria dos casos, não apresentem correlação com os potenciais calculados termodinamicamente, os valores experimentais de $E_{H}$ podem auxiliar significativamente no mais completo entendimento da química dos ambientes aquáticos. ${ }^{(59-66)}$

\section{9. medidas de $\mathrm{pH}$}

Assim como o potencial redox $\left(E_{H}\right)$, ○ pH é um bom parâmetro para indicar as condições da amostra e os eventuais processos químicos e/ou biológicos que estejam osorrendo no sistema natural. Estritamente falando, o pH de sedimentos é um parâmetro complementar ao $E_{H}$ e sua medida, assim como a medida de $E_{H_{1}}$ requer um cuidado especial. Bates ${ }^{(6)}$ em sua obra mais recente, aponta para os cuidados que se deve ter nas medidas de $\mathrm{pH}$ em amostras reais.

Além das medidas isoladas de $\mathrm{pH}$, as correlações entre $\mathrm{E}_{\mathrm{H}}$ e $\mathrm{pH}$ podem ser extremamente úteis no estudo de ambientes aquáticos ${ }^{(59,60)}$. Berner ${ }^{(68)}$ realizou medidas em conjunto de $\mathrm{E}_{\mathrm{H}}$ e de $\mathrm{pH}$, a fim de calcular as atividades de equílibrio de íons sulfeto e polissulfetos, além da pressão parcial de $\mathrm{H}_{2} \mathrm{~S}$.

Um problema frequentemente encontrado em eletrodos de $\mathrm{pH}$ de junção líquida é a ocorrência de contaminação por íons estranhos (por exemplo sulfetos), que reagem com a prata contida no interior do eletrodo ao nível da membrana e obstruem o orifício. Um sistema extremamente interessante foi recentemente desenvolvido pela Ingolg, denominado Argenthal ${ }^{\circledR}$, que consiste de um tubo de vidro com grãos de $\mathrm{AgCl}$ e $\mathrm{Ag}^{0}$, isolados do eletrólito de $\mathrm{KCl}$. Com isso, a concentração dos ions de $\mathrm{Ag}^{+}$na solução é muito menor que nos eletrodos combinados comuns, não ocorrendo a obstrução do orifício. Este tipo de eletrodo é apropriado para medidas de $\mathrm{pH}$ em amostras reais, que contenham significativas quantidades de íons $\mathrm{S}^{2-}$. 
Ao contrário das medidas de $\mathrm{E}_{\mathrm{H}}$, as medidas de $\mathrm{pH}$ são muito mais rápidas, podendo-se obter leituras estáveis e reprodutíveis em cerca de 1 minuto, ou menos.

\subsection{0. espectrofotometria de absorção atómica na determinação de metais pesados}

Dentre as técnicas utilizadas na determinação de metais, a espectrofotometria de absorção atômica é sem dúvida alguma a técnica mais consagrada. Há pelo menos 30 anos, ela vem sendo utilizada para a determinação de metais nas mais diversas matrizes.

Com relação às matrizes geológicas, como sedimentos e solos, há na literatura atualizaçōes completas sobre os métodos de absorção atômica na análise de metais. ${ }^{(69,70)}$. Os problemas analíticos mais frequentes são discutidos, tais como interferências, efeitos de matriz, etc.

Segundo Fiedler ${ }^{(10)}$, os efeitos de matriz influem significativamente no limite de deteccão e na exatidão das análises.

Nas análises realizadas por absorção atômica, a velocidade de fluxo é influenciada por diversos fatores: viscosidade, tensão superficial, temperatura, quantidade de sais dissolvidos, pressão dos gases na nebulização e até as dimensões do capilar. Dentre todos os fatores citados, o mais importante é a viscosidade. Kojima e Lida ${ }^{(1)}$ consideraram que a velocidade de fluxo da amostra é praticamente inversamente proporcional à sua viscosidade. A adição de um solvente orgânico que modifica o mecanismo de atomização pode aumentar o fluxo e consequentemente, a sensibilidade das medidas ${ }^{(72)}$.

Um elemento que merece uma atenção especial com relação a problemas de interferências, é 0 cromo. Tiglea ${ }^{(73)}$ estudou detalhadamente as características deste elemento em absorção atômica, e estabeleceu condições significativamente favoráveis de análise. Rubio et al. ${ }^{(4)}$ revisaram sobre a 
determinação deste elemento e consideram que não existe uma recomendação específica para o tipo de chama mais favorável, bem como o efeito de substâncias interferentes.

De um modo geral, a técnica de absorção atômica por chama não apresenta problemas associados a efeitos de matriz incontornáveis, podendo-se utilizar o método de adição de padrăo, ou ainda curvas de padrões matrizadas, i.e., padrões preparados em conjunto com os reagentes de extração ${ }^{(10)}$. Esses métodos são principalmente aplicados aos procedimentos de extração sequencial, onde as concentrações dos reagentes utilizados nas extraçōes são significativamente elevadas. Kersten e Förstner ${ }^{(35)}$, dentre outros autores $^{(10,16,17,25,26,32,34,36,44,46,57,74)}$, enfatizam a significativa performance que esta técnica apresenta na determinação de metais pesados em sedimentos.

Alguns elementos existem nos sedimentos em concentrações tais que a técnica por chama näo apresenta sensibilidade analítica satisfatória à suas determinaçōes (p.e., Cd), sendo necessário utilizar a espectrometria de absorção atômica com atomização eletrotérmica (forno de grafite).

\subsection{Sulfeto Ácido Volátil (SAV)}

Berner $^{(75)}$, uma das maiores autoridades no campo das pesquisas geoquímicas de sulfetos, definiu sulfeto ácido volátil (conhecido na língua inglesa como Acid Volatile Sulfide, AVS) como sendo o sulfeto removido das amostras de sedimentos, através de uma extração ácida à frio (p.e., $\mathrm{HCl} 6 \mathrm{M}$ ). Segundo o autor, este sulfeto amorfo (FeS), que sofre dissolução ácida, é composto de uma mistura de grãos muito finos de mackinawita e greigita $\left(\mathrm{Fe}_{3} \mathrm{~S}_{4}\right)$, que durante um processò de transformação geológica bem caracterizado, conhecido como processo diagenético, se transforma em pirita $\left(\mathrm{FeS}_{2}\right)$. Pelo fato do sulfeto amorfo sofrer ataque por ácido, tanto diluído, quànto concentrado, enquanto que a pirita 
não sofre qualquer ataque nessas condições, o sulfeto ácido volátil é também chamado de sulfeto de ferro metaestável. Dentre as formas minerais existentes de ferro e sulfeto presentes nos sedimentos, a pirita é o mais abundante. A razão estabelecida entre a quantidade de pirita e SAV tem sido usada como um indicador histórico no esclarecimento da gênese de sedimentos marinhos e de águas interiores ${ }^{(66-78}$ ). Além disso, o sulfeto determinado como SAV está diretamente associado à complexação de alguns cátions metálicos ${ }^{(79,80)}$.

A determinação de SAV pode ainda proporcionar informações relevantes sobre a extensão de contaminação ambiental, através do reconhecimento do tipo de união entre os metais e os sedimentos. Com isso, pode-se inferir parâmetros relacionados à mobilidade e a toxicidade desses metais. ${ }^{(10)}$

Ainda no campo da toxicidade de sedimentos, vários autores consideram que diferentes sedimentos exibem diferentes graus de toxicidade para uma mesma quantidade de metal. Essas diferenças têm sido atribuidas à resposta que os organismos apresentam às concentrações químicas na água intersticial dos sedimentos $^{(81-83)}$. Di Toro et al..$^{(84)}$ estudaram a relação existente entre SAV e o metal que é extraído simultaneamente, chamado de SEM (simultaneously extracted metal), a fim de avaliar a extensão de contaminação de amostras de sedimentos. Para as amostras testadas, foi verificado que a atividade do metal no sistema água intersticial / sedimento, como medida de toxicidade aguda a organismos bentônicos, é fortemente influenciada por sulfeto volátil e pelo metal extraído do sedimento, utilizando-se $\mathrm{HCl}$ à frio, numa concentração de $0,5 \mathrm{M}$. Muitos estudos relacionados à razão SEM / SAV e seus aspectos toxicológicos têm sido descritos recentemerte na literatura. ${ }^{(85-91)}$ Pode-se encontrar ainda trabalhos que ilustram a ação dc sulfeto volátil no controle dos metais durante as ciclagens óxidas e anóxidas emi lagos ${ }^{(92)}$. Ainda neste tema, vale ressaltar os esforços de Roden e Tuttle ${ }^{(33)}$, na busca de uma explicação para as transformações de compostos de enxofre em ambientes estuarinos.

As metodologias mais cor ıuns utilizadas na determinação de sulfeto ácido 
volátil são a potenciometria com eletrodo íon-seletivo ${ }^{(97-100)}$, espectrofotometria ${ }^{(101-}$ ${ }^{103)}$ e cromatografia em fase gasosa ${ }^{(104-105)}$.

Morse et al. ${ }^{(106)}$ publicaram uma excelente revisão sobre sulfetos em águas e dedicam grande parte do trabalho ao aspecto de eficiência de extração de SAV, e outras fases minerais.

\subsection{2. granulometria}

Segundo Barbanti e Bothner ${ }^{(10)}$, há um consenso que o determinação do tamanho de grãos dos sedimentos é um parâmetro de grande importância na avaliação dos gradientes e nas mudanças temporais das concentrações dos contaminantes presentes. Considera-se que textura dos sedimentos pode controlar a concentração dos elementos traço através dos seguintes mecanismos: (1) sedimentos finamente granulados têm uma maior capacidade de remoção e adsorção de metais, quando comparados aos de maior tamanho de grãos, por causa de sua maior área superficial; (2) essas superfícies são frequentemente mais "reativas" que a fase mineral carreadora porque elas contém fases químicas tais como hidróxidos de ferro (III) e manganês(IV), além de matéria orgânica ${ }^{(108-}$ 110); (3) minerais específicos (carbonatos, minerais pesados, etc.) podem estar concentrados em certos tamanhos de grãos, dependendo da dinâmica do ambiente sedimentar.

Devido às propriedades de acúmulo e redistribuição, os sedimentos são frequentemente utilizados no monitoramento de metais pesados em ambientes aquáticos $^{(111)}$. A extensão de contaminação de um determinado sedimento é avaliada a partir do efeito concernente ao tamanho de grãos, pois diferentes tamanhos podem acumular diferentes quantidades de metais. Estudos sobre a correlação entre os metais e a fração de tamanho de partículas de sedimentos sugerem que os sedimentos mais finos (frações silte; $<63 \mu \mathrm{m}$ e argila; $<20 \mu \mathrm{m}$ ) fíeçueritiemente contenham as maiores concentrações de metais ${ }^{(112-114)}$. Por isso, 
deve-se proceder a uma correção caso se queira conhecer a verdadeira contribuição de contaminação de metais pesados em sedimentos. Pode-se encontrar na literatura diversos procedimentos de correção, baseados no efeito de tamanho de grãos ${ }^{(111)}$.

Muitos métodos têm sido propostos para "normalizar" a variabilidade na distribuição dos metais que resulta da dependência da textura ${ }^{(108,110)}$ : proporção entre elementos conservativos; proporção em argilominerais; análise da fração que contém partículas com dimensão $<63 \mu \mathrm{m}$; extrapolação das curvas de regressão; fracionamento físico do sedimento total dentro das frações de tamanhos distintos e subsequente análise de cada classe. O método de fracionamento físico fornece a informação mais compreensiva do efeito concernente aos tamanhos de grãos, embora seja a técnica de maior consumo de tempo.

Pelo fato da fração mais fina apresentar uma concentração maior de metais

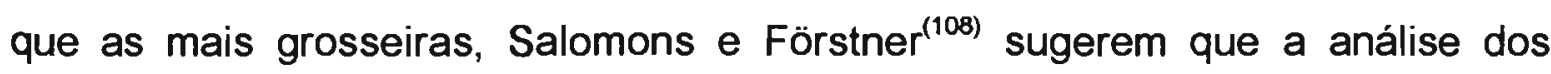
metais seja realizada nesta fração, a fim de que os resultados possam ser intercomparados entre diversos grupos. ${ }^{(111)}$

Um outro aspecto interessante do levantamento da fração silte / argila está no fato de que ela se aproxima significativamente das dimensões encontradas nos sólidos em suspensão, o que vem a contribuir na avaliação da dinâmica de transferência de metais no ecossistema.

Com relação à análise granulométrica de um determinado sedimento, é fundamental frisar que durante o procedimento básico (peneiramento, secagem, etc.) deve-se procurar causar a menor modificação possivel na amostra original. Wall et al. ${ }^{(115)}$ observaram que durante a separação da fração silte / argila da amostra, com técnicas de dispersantes químicos, agitação mecânica e subsequente peneiramento, quantidades consideráveis das partículas pequeninas se agregaram às maiores.

Ackermann et al. ${ }^{(111)}$ contornaram o problema de agregação das partículas 
adaptando a peneira no interior de um bequer com água e o conjunto submetido à ultrassom, a fim de separar as frações $<60 \mu \mathrm{m}$ e $<20 \mu \mathrm{m}$. Os autores verificaram que durante um periodo de 15 a 20 minutos, a variação da distribuição dos tamanhos de grãos variou somente de 1 a $4 \%$.

\subsection{3. análise textural por microscopia eletrônica de varredura}

A microscopia eletrônica de varredura (MEV) baseia-se na interação de um feixe de elétrons com a amostra a ser estudada. Como resposta a esta interação, tem-se a geração de elétrons secundários, elétrons retroespalhados, elétrons Auger, luz e raios-X, além de elétrons tran£mitidos. ${ }^{(116)}$ Na microscopia eletrônica de varredura, as propriedades topográficas da amostra controlam a emissão dos eletrons secundários, de forma que a captação dos mesmos fornece uma imagem da área varrida pelo feixe primário, semelhante à observada em um microscópio de luz refletida. Variações nas magnitudes das demais excitações podem também ser captadas e fornecer outras informações de carater químico. Um sistema de EDS (do inglês Energy Dispersive X-Ray), que capta os raios-X característicos dos elementos contidos na região da amostra analisada, separando os diferentes comprimentos de onda das radiações emitidas com base em suas energias, permite a obtenção de análises químicas simultâneas à obtenção de imagens ${ }^{(116)}$. As análises químicas podem ser qualitativas com a obtenção do espectro com todos os elementos detectáveis presentes ou quantitativas se forem utilizados padrões e efetuadas as correçōes necessárias.

A utilização de MEV, acoplado ou não a um sistema EDX, em estudos de alteração de rochas tem sido cada vez mais frequente desde o fim dos anos 60 , pois fornece informaçōes sobre a morfologia dos materiais e suas interrelações, além de dados sobre a sua composição química através do EDX.

Embora a técnica de MEV possua uma potencialidade significativa de aplicação em amostras ambientais, sob o aspecto de contaminação dessas 
amostras, ela ainda não pode ser considerada de ampla aceitação no campo da química ambiental. Segundo Luther III et al. ${ }^{(117)}$, a microscopia eletrônica de varredura pode ser extremamente útil na informação precisa da forma que os metais estão associados como partículas individuais em sedimentos suspensos. Pode ainda demonstrar a natureza exata do material particulado na coluna de água, bem como a forma de associação dos metais.

\subsection{4. determinação de carbono total}

Nos ecossistemas aquáticos os fluxos de carbono e outros nutrientes são dependentes das rotas pelas quais ocorrem os processos de assimilação dos elementos e de decomposição dos recursos orgânicos

Nesse sentido, as atividades microbianas controlam, em muitos casos, as concentrações dos nutrientes e de muitos constituintes orgânicos afetando, indiretamente, a presença de substâncias e os ciclos biogeoquímicos sob condições especificas de $\mathrm{pH}$ e de potencial redox ${ }^{(118)}$.

No que se refere à degradação de contituintes orgânicos em sistemas aquáticos, verifica-se que esse processo é constituido basicamente de 3 mecanismos: lixiviação, catabolismo e cominuição/fragmentação ${ }^{(119)}$.

A determinação de carbono (orgânico, inorgânico e total) em amostras de sedimentos permite estimar os processos de mineralização e de imobilização da matéria orgânica e com isso avaliar o grau que estes processos possam estar ocorrendo. Tal avaliação é significativamente importante nos estudos de áreas degradadas.

Albuquerque ${ }^{(120)}$ cita que Redfield ${ }^{(121)}$ estabeleceu uma relação entre os principais elementos que compõem as moléculas orgânicas ( $C, N$ e $P$ ), sendo esta razão fundamental para a formulação de um modelo de circulação destes elementos em rios, estuários, oceanos etc. Assim, a razão de Redfield ${ }^{(121)}$ ou 
razão $\mathbf{C}: \mathbf{N}: \mathbf{P}$ estabelece valores definidos para diferentes materiais, podendose através dela, concluir sobre a origem do material analisado, além do estado de decomposição.

Conhecendo-se os niveis de carbono em sedimentos, pode-se estabelecer importantes correlações como p.e., matéria orgânica e sua interação com metais pesados, quer pela formação de adsorbatos ${ }^{(16)}$, quer por complexação com ácidos húmicos $^{(32)}$.

\subsection{5. isolamento e caracterização de ácidos húmicos}

Os constituintes orgânicos de solos e sedimentos recentes são impcrtantes agentes de intemperismo bem como agentes para a mobilização, transporte e concentração de elementos traço ${ }^{(122-123)}$.

As substâncias húmicas representam 60 a $80 \%$ da matéria orgânica presentes nos sedimentos de água doce e marinhos ${ }^{(124)}$. Tais substâncias são classificadas como compostos orgânicos não celulares, diferenciando-se das chamadas substâncias celulares oú não húmicas, tais como açúcares, aminoácidos, lipídeos etc ${ }^{(126)}$.

Já há um bom tempo são conhecidas as importantes propriedades de ácidos húmicos de solos e de sedimentos associarem-se a metais traço. ${ }^{(124-126)}$ Daí, as fases orgânicas serem consideradas como enriquecedoras de metais ${ }^{(123)}$ As propriedades de quelação e complexação com cátions metálicos conferem para os ácidos húmicos um papel importante nos processos naturais ${ }^{(124)}$.

Hirner et al. ${ }^{(123)}$ estudar:am a associação de diversos metais com componentes orgânicos (princif:almente ácidos húmicos) em sedimentos, e verificaram que há um enriquecimento significativo desses metais na fração orgânica ( 3 ordens de magnitude), comparativamente ao sedimento total, demonstrando a importância da fração orgânica na fixação e no transporte de elementos traço nos sedimentos. 
Nos métodos de extração sequencial de Tessier et al. ${ }^{(34)}$ e de Kersten e Förstner ${ }^{(35)}$, os ácidos húmicos integram as fraçōes "matéria orgânica" e "sulfetos e matéria orgânica", respectivamente, pois não podem ser determinados sozinhos sem se evitar reações indesejáveis, tais como: hidrólise, oxidação, precipitação, etc ${ }^{(131)}$. Além disso, o isolamento da fração húmica dos sedimentos não é uma tarefa rápida, nem simples, o que inviabiliza os trabalhos tipicamente de rotina. Desta forma, há uma escassez de dados sobre ácidos húmicos isolados de sedimentos, para fins de caracterização, o que sugere uma proposta significativamente interessante de estudo.

\section{OBJETIVOS}

Este estudo teve como objetivo principal a caracterização de amostras de sedimentos do Rio Tietê, a fim de se estabelecer um protocolo de procedimentos. Para isso, procurou-se acompanhar minuciosamente as condiçōes de conservação de suas amostras de sedimentos de fundo, a fim de se testar a validade de estocagem, bem como as formas apropriadas de manuseio. $O$ ambiente de coleta estudado apresenta-se significativamente impactado sob o ponto de vista ambiental, principalmente nos pontos mais próximos da região metropolitana de São Paulo. Um dos aspectos da importância deste estudo está no fato de que amostras de ambientes tipicamente "estressados", como são as do Tietê, são dotadas de extrema anoxia (ausência de $\mathrm{O}_{2}$ ) e portanto muito instáveis. Consequentemente, erros de manipulação e de estocagem podem conduzir a interpretaçōes ambientais equivocadas.

Desta forma, a partir da verificação das melhores condições de manuseio e conservação dessas amostras, delineou-se os seguintes objetivos especificos:

- propor alguns desenvolvimentos metodológicos fundamentais para amostras de sedimentos, tais como: 
a - potencial redox $\left(E_{H}\right)$

$\mathrm{b}-\mathrm{pH}$

c - sulfeto ácido volátil (SAV)

d - determinação da concentração total, das possiveis formas e da biodisponibilidade dos metais pesados presentes nos sedimentos, por espectrofotometria de absorção atỏmica

e - análise granulométrica

$f$ - análise textural, através de microscopia eletrônica de varredura (MEV)

$\mathrm{g}$ - análise de carbono total, orgânico e inorgânico

$\mathrm{h}$ - isolamento e caracterização de ácidos húmicos

- A partir das metodologias estabelecidas, pretende-se contribuir com um protocolo de estudo para outros sedimentos contaminados e seu potencial de redistribuição de metais pesados para a biota aquática. Este protocolo de procedimentos, desde que devidamente estabelecido, além de permitir inferir consideraçōes ambientais ao Rio Tietê, no tocante às ações de recuperação deste importante ecossistema, poderão auxiliar significativamente no acompanhamento de outros ambientes similarmente impactados. Vale ressaltar que $\circ$ Rio Tietê até o presente foi muito pouco estudado sobre as características dos seus sedimentos de fundo e existem hipóteses de que os efluentes gerados na região metropolitana de São Paulo possam estar influindo na qualidade do reservatório de Barra Bonita, a cerca de $260 \mathrm{Km}$ da capital. 


\section{PARTE EXPERIMENTAL}

\section{1. a área de estudo - O Rio Tietê}

O Rio Tietê é parte integrante da Bacia Hidrográfica do Alto Paraná, constuindo-se num dos rios mais importantes do Estado de São Paulo. Este rio, assim como o Rio Paranapanema, tem sua nascente junto a Serra do Mar e atravessa os três compartimentos de relevo do Estado (Planaltos e Serras clo Atlântico Leste-Sudeste; Depressão da Borda Leste do rio Paraná e Planalto Ocidental Paulista, respectivamente), antes de desaguar no rio Paraná. Sua extensão é de aproximadamente $1100 \mathrm{Km}$ e é navegável em boa parte de seu curso.

A área de estudo do Tietê escolhida neste trábalho situa-se inicialmente a cerca de $50 \mathrm{Km}$ do centro de São Paulo, a oeste da capital, abrangendo em parte os municípios de Pirapora do Bom Jesus e Santana de Parnaíba e estende-se em $260 \mathrm{Km}$, até o reservatório de Barra Bonita. Este trecho é considerado o mais crítico, segundo os últimos boletins de qualidade de águas interiores do Estado, publicados pela CETESB ${ }^{(127-130)}$. A figura 1 ilustra a região do Tietê estudada: 

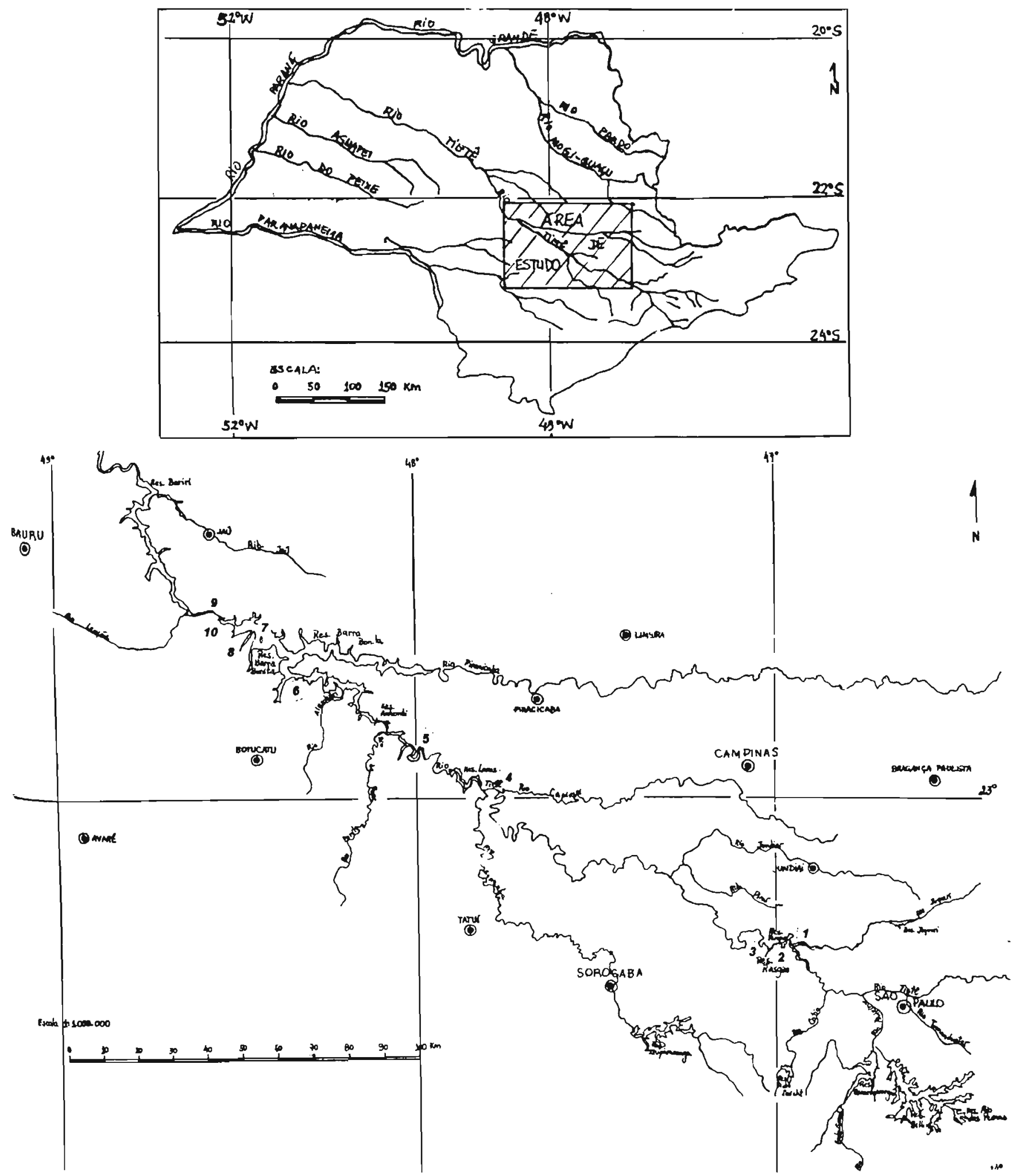

FIGURA 1: Rio Tietê e os respectivos pontos amostrais : (1) Pirapora; (2) Rasgão; (3)Tecelagem; (4) Rodovia Tietê-Capivari; (5) entrada de Barra Bonita; (6) margem esquerda de Barra Bonita;(7) itha de Barra Bonita, (8) ilha ponto 7; (9) jusante de Barra Bonita; (10) Zé do Calção.

o trecho escolhido abrange um tctal de aproximadamente 60 cidades, que lançam 
lançam seus dejeitos municipais e industriais nas águas do Tietê. As margens do Tietê são constituidas neste trecho essencialmente de gramíneas, vegetação pobre e que não pode evitar efeitos erosivos das margens, ou mesmo assoreamento.

Devido à sua estratégica posição geográfica, vários reservatórios foram construídos principalmente na região próxima à capital, específicamente em Pirapora do Bom Jesus e Santana do Parnaíba. Esses reservatórios têm uma função importante tanto como fonte de energia, quanto ao manejo de balanço hídrico, a fim de prevenir as inundações decorrentes das ocupações das margens, além de possibilitarem tráfego de embarcações e ainda recreação, irrigação, pesca, fontes de água de abastecimento e descarga de esgotos ${ }^{\text {(131) }}$

$O$ trecho inicial (figura 1 ) é formado por um conjunto de 3 reservatórios. As águas do Tietê são represadas no reservatório de Pirapora (a norte de Santana do Parnaiba), Rasgão (a oeste de Pirapora do Bom Jesus) e no pequeno reservatório de Tecelagem (a norte de Pirapora do Bom Jesus).

O reservatório de Pirapora é o maior e o mais importante deste conjunto e faz parte do chamado Sistema Alto Tietê - Região Metropolitana de São Paulo, que consiste de uma série de obras hidráulicas construídas ao longo do rio Tietê e principais afluentes ${ }^{(132)}$.

O reservatório principal tem sido operado em função não apenas das próprias regras operacionais do Sistema Alto Tietê adotadas pela Eletropaulo, como ainda em função dos problemas advindos da formação de espumas, odores e navegação turística na cidade de Pirapora do Bom Jesus. Os reservatórios de Rasgão e Tecelagem, por sua vez, sempre foram operados em conjunto com o de Pirapora, devido às proximidades entre si e suas pequenas capacidades de armazenamento. ${ }^{(133)}$

Após o reservatório de Tecelagem, o rio apresenta um forte efeito de encachoeiramento em certas partes por tratar-se de um rio típico de planície de inundação, onde pode-se verificar uma leve melhoria da água, principalmente nas próximidades das regiões de ltú, Tietê, Salto e Sorocaba, até o reservatório de Barra Bonita, cuja extensão é cerca de $20 \mathrm{Km}$. A principal finalidade deste ${ }_{32}$ 
reservatório, é, assim como o de Pirapora, a geração de energia, embora seja também utilizado para outros fins, incluindo a irrigação, piscicultura, abastecimento e recreação ${ }^{(134)}$.

\section{2. a qualidade ambiental do Tieté}

Os relatórios anuais de qualidade de águas interiores do Estado de São Paulo elaborados pela CETESB durante o período de 1991 a 1994 mostram que a qualidade das águas do Tietê pioraram drasticamente neste período. Os parâmetros de qualidade, chamados de IQA (Índice de Qualidade das Águas) indicam haverem níveis superiores aos estabelecidos pela resolução CONAMA $n^{\circ} 20$, para demanda bioquimica de oxigênio (DBO), nitrogênio total, fósforo total, turbidez, coliformes fecais e surfactantes ${ }^{(131)}$. $O$ oxigênio dissolvido está em sua maior parte ausente ou em níveis muitos baixos nas águas superficiais. No inverno (época de estiagem), refletindo a qualidade das águas provenientes da cidade de São Paulo, o reservatório de Pirapora apresenta-se totalmente anóxido (ausente de $\mathrm{O}_{2}$ ), em toda sua extensão, bem como no trecho correspondente à saida do reservatório de Rasgão até a entrada do reservatório de Barra Bonita, como veremos adiante. No verão (época de chuvas), as concentrações de espécies contaminantes são menores em relação ao inverno, porém, as características anóxidas do ambiente permanecem.

Algumas espécies químicas são encontradas em níveis muito elevados, sulfetos e alguns gases, tais como metano e gás sulfídrico $\left(\mathrm{H}_{2} \mathrm{~S}\right)^{(132)}$.

Embora se saiba que os sedimentos são significativamente importantes tanto em programas de monitoramento, quanto em estudos específicos de corpos d'água, pouco se tem realizado nesse sentido no Tietê.

Eysink et al. ${ }^{(135)}$ determinaram as concentraçōes totais de diversos metais pesados nos sedimentos do Tietê, no trecho considerado crítico, entre Pirapora e Barra Bonita e inferiram importantes consideraçōes a respeito da contaminação de Barra Bonita proveniente de metais pesados, que segundo eles, são "exportados" da região metropolitana de São Paulo. 
As elevadas concentrações de metais e de outras espécies, como as apontadas acima, são decorrentes da carga poluidora lançada diariamente no Tietê (estimada em 1994 como sendo 1100 toneladas). Deste total, cerca de 700 toneladas são oriundas de esgotos municipais e 400 toneladas de dejeitos industriais, que não sofrem qualquer tratamento prévio. ${ }^{(136)}$

O reservatório de Barra Bonita vem sendo estudado por Tundisi \& Matsumura-Tundisi ${ }^{(134)}$, sob os aspectos limnológicos e de sua eutrofização. Outros autores, como Grimberg et al. ${ }^{(137)}$, têm considerado o reservatório de Barra Bonita como um sistema eutrófico, que recebe cargas residuárias industriais e domésticas num nível elevado, havendo na região de Barra Bonita, predomínio da vegetação de cana de açúcar devido à presença de uma das maiores indústrias de álcool e de açúcar do Estado.

\section{3. coleta de amostras de sedimentos}

Dentro do "Programa de Despoluição do Rio Tietê", vários grupos interdisciplinares começaram a estudar os complexos aspectos ambientais que envolvem este ecossistema e os sedimentos passaram a ser considerados prioridade de estudo, pois dados sobre este compartimento ambiental são significativamente escassos e não levantados pela CETESB nos seus programas de monitoramento. Sabe-se que o rio Tietê ao passar próximo da região metropolitana de São Paulo, apresenta uma dinâmica intensa de sedimentação, devido ao represamento de suas águas e portanto, os sedimentos têm uma participação significativa tanto na estocagem, quanto na redistribuição de poluentes.

As coletas de sedimentos de fundo foram realizadas na estação das chuvas, no mes de janeiro de 1993. A escolha dos pontos foi baseada nos levantamentos preliminares dos relatórios de qualidade de águas interiores do Estado e de uma soma de esforços em se estabelecer um protocolo de ações concatenadas entre o grupo de Recuperação de Ecossitemas Aquáticos da CETESB, coordenado por Geraldo J.G. Eysink, sua equipe e o Laboratório ${ }_{34}$ 
de Química Analítica do Instituto de Química da USP, de responsabilidade do Prof.Dr. Jaim Lichtig.

Nesta campanha, um total de 10 pontos amostrais foram estudados, sendo tres na região de Pirapora, dois equidistantes dos pontos inicial e final e cinco na região de Barra Bonita.

As amostras foram coletadas ao longo dos $260 \mathrm{Km}$ utilizando-se um bote de borracha inflável. Um cuidadoso critério amostral foi adotado, como distância entre as margens, entradas de tributários e outros cuidados que devem constar de um bom protocolo de procedimentos ${ }^{(1)}$.

A coleta dos sedimentos de fundo foi realizada com uma draga de Birge Ekman, cujo esquema está ilustrado na figura 2:

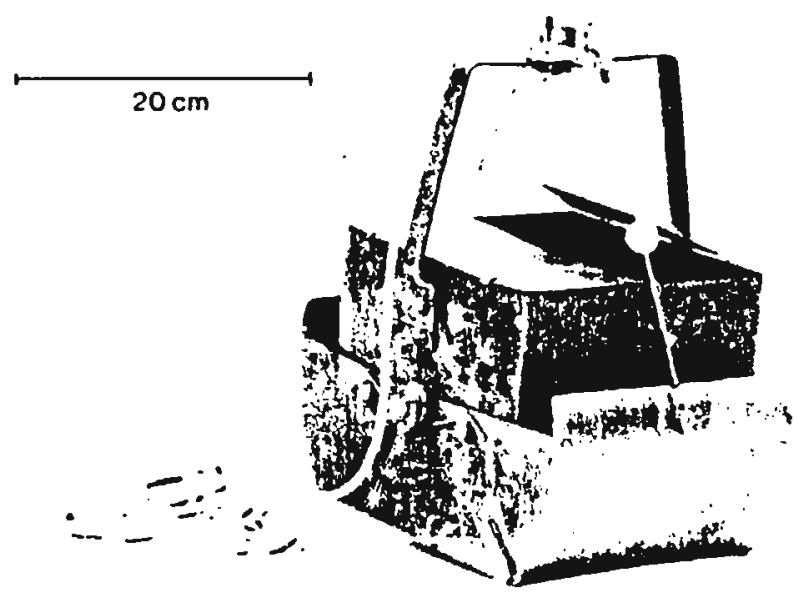

FIGURA 2: esquema da draga de Birge-Ekman

Esta draga é apropriada para a coleta de materiais peculiares, tais como grãos finos, sedimentos leves, silte, lama, etc., além de ser recomendada para ambientes com pequena correntizza ${ }^{(1,57)}$. Trata-se de uma draga construída em aço inox-316 com um peso de, aproximadamente, $3,2 \mathrm{Kg}$. As dragas de BirgeEkman consideradas padrão, como a utilizada neste trabalho, apresentam uma área de amostragem de $15 \times 15 \mathrm{~cm}$. 
O compartimento destinado à amostra é composto de um par de mandibulas que são acionadas através de um sistema com molas. A parte superior do compartimento apresenta dois "flaps", que permanecem abertos, em conjunto com as mandíbulas quando se lança a draga para o fundo do rio. As mandíbulas ao tocarem no fundo se fecham rapidamente e o material, desta forma, pode ser trazido para a superfície. Vale ressaltar que ao se trazer a draga de volta para a superfície, as mandíbulas ficam hermeticamente fechadas, evitando assim que o sedimento sofra alguma alteração com a água. Da mesma forma, os "flaps" se fecham devido à elevada pressão da coluna de água, que força-cs para baixo, evitando também alteraçōes na amostra original.

\section{4. acondicionamento das amostras de sedimentos}

O material recolhido foi disposto rapidamente em uma bandeja plástica utilizando-se uma colher, ambas de polietileno. Para a determinação de metais pesados, retirou-se a porção de sedimento presente no centro da draga, pois essa porção do material não entra em contato com a superfície metálica do equipamento.

As amostras foram transferidas das bandejas para o interior de frascos de polietileno (de alta densidade), com boca larga e batoque, tomando-se o cuidado de preenchê-los totalmente. Durante a disposição das amostras de sedimentos, foi observado que as de Pirapora, Rasgão, Tecelagem, Ponte do rio TietêCapivari apresentaram um forte odor de sulfetos, além de um aspecto típico de ambiente deposicional, como uma camada muito fina de material negro, como sulfeto de ferro ${ }^{(93)}$ e matéria orgânica em processo de decomposição ${ }^{(118)}$. Já os sedimentos da região de Barra Bonita apresentaram menos odor de sulfetos, além de um aspecto completamente diferente dos de Pirapora, bem mais claros e com predominância de material arenoso.

Vale ressaltar que os sedimentos dos primeiros 4 pontos, quando secos em estufa, formam torrōes muitos 
compactados, enquanto que os da região de Barra Bonita formam aglomerados granulados com forte presença de sílica em sua constituição.

Após a disposição final das amostras, os frascos foram identificados segundo o nome da estação correspondente, um número de controle e guardados no interior de um saco escuro, a fim de mantê-los ao abrigo da luz. Finalmente, esses sacos foram mantidos em uma geladeira de isopor com gelo.

A fim de se evitar quaisquer contaminaçōes provenientes dos recipientes utilizados, seguiu-se as recomendações de Durst ${ }^{(138)}$. Sendo assim, os recipientes e materiais foram submetidos a uma série de tratamentos previamente, como segue:

a - $\mathrm{HCl}, 50 \%, 1$ semana,

b - água destilada,

c - $\mathrm{HNO}_{3} 50 \%$, 1 semana,

d - água destilada,

e - água deionizada e fechar hermeticamente até o uso.

As bandejas e colheres também foram submetidas a lavagens com $\mathrm{HNO}_{3}$ $(30 \%)$ e várias lavagens com água deionizada.

No laboratório, as amostras foram divididas em sub-amostras para cada finalidade especifica. O material restante foi guardado rapidamente num refrigerador, a $4^{\circ} \mathrm{C}$. Todas o manuseio com as amostras de sedimentos foram realizados em atmosfera de nitrogênio puro ( $N_{2}$ grau $P P$, Oxigênio do Brasil), a fim de preservar a integridade das mesmas, principalmente as de natureza anóxida.

O acompanhamento das condições de conservação das amostras foi realizado mensalmente, através de medidas de $\mathrm{E}_{\mathrm{H}}$ e de $\mathrm{pH}$. 


\section{5. determinação do potencial redox $\left(E_{H}\right)$}

Nas determinações de $E_{\mathrm{H}}$, foram utilizados um potenciômetro digital Micronal, mod.375, com precisão de $\pm 0,1 \mathrm{mV}$, um eletrodo de anel de platina (de grande área) Ingold e um eletrodo de referência $\mathrm{Ag} / \mathrm{AgCl}$ Ingold de gel polímero $\left(X e r o / y t(B)\right.$, não contaminável por íons $\mathrm{S}^{2-}$. Conforme está descrito no item 1.4.5, o potencial do eletrodo de $\mathrm{Pt}$ vs. $\mathrm{Ag} / \mathrm{AgCl}$ foi verificado através de medidas em solução de ZoBell $\left(\mathrm{K}_{3} \mathrm{Fe}(\mathrm{CN})_{6} / \mathrm{K}_{4} \mathrm{Fe}(\mathrm{CN})_{6}, 0,003 \mathrm{M}\right.$, em meio de $\left.\mathrm{KCl} 0,1 \mathrm{M}\right)$. Simultaneamente realizou-se a medida da temperatura.

Através de nossos experimentos, foi observado que quando se utiliza um eletrodo de referência como p.e., $\mathrm{Ag} / \mathrm{AgCl}$, a equação da célula passa a ser :

$$
E_{H}=260-1,6 \mathrm{~T} \quad \text { eq. } 2.1
$$

onde $\underline{E}_{H}$ é o potencial lido (em $\mathrm{mV}$ ) e I é a temperatura da solução de ZoBell. Foi verificado que quando o sistema rião apresenta problemas, leituras estáveis de potencial podem ser atingidas rapidamente, em cerca de 5 segundos. As amostras foram retiradas do refrigerador, aguardando-se o tempo necessário até atingirem a temperatura ambiente. Em seguida, foram abertas em atmosfera de nitrogênio, cobrindo-se imediatamente a boca do frasco com filme de PVC, que se mostrou extremamente eficiente nesta operação. Perfurou-se o filme para a introdução dos eletrodos de Platina e de referência $(\mathrm{Ag} / \mathrm{AgCl})$, que foram mergulhados cerca de $5 \mathrm{~cm}$ no interior da amostra, a fim de se registrar o valor mais fixo de $E_{\mathrm{H}}$. Valores obtidos próximos às camadas superiores se apresentam um pouco menos estáveis, por causa da constante exposição desta camada com $\circ \mathrm{O}_{2}$ do ar. ${ }^{(139)}$ Foi aguardado um tempo de 5 a 10 minutos para se anotar o valor de $E_{H}$. Entre uma e outra amostra, os eletrodos foram lavados e uma nova leitura com a solução de Zobell foi realizada, a fim de se verificar algum possível efeito de contaminação das amostras na superfície da platina. Algumas vezes (quando $o$ 
tempo de contato do eletrodo de Pt com as amostras foi superior a 30 minutos) foi necessária a limpeza do eletrodo com polimento e nos casos mais drásticos, com solução sulfocrômica. A cada mês, durante 30 meses, novas leituras de $E_{H}$ foram realizadas.

Um estudo comparativo realizado com algumas amostras, evidenciou não haver diferenças significativas nos resultados quando se realizam medidas de potenciais redox com o sistema simples (com o filme de PVC cobrindo a boca do frasco e cânula de $\mathrm{N}_{2}$ ) e com um glove bag. Porisso, adotamos o sistema mais simples, também por ser mais prático e exigir menos tempo de operação.

\section{6. determinação de pH}

As determinações de $\mathrm{pH}$ dos sedimentos foram realizadas imediatamente às medidas de $E_{H}$, utilizando-se um eletrodo combinado de $\mathrm{pH}$ Ingold, dotado de sistema Argenthal ${ }^{\circledast}$ que não sofre contaminação por ions $\mathrm{S}^{2-}$. A calibração do eletrodo foi realizada segundo a orientação da National Bureau of Standards (NBS), com os tampões 4,$01 ; 6,86$ e $9, ` 8 ;$ a $25^{\circ} \mathrm{C}$. Não foram verificados valores inferiores a $58 \mathrm{mV} / \mathrm{pH}$ em nenhuma das calibrações realizadas. A fim de se manter um bom nível de confiabilidade analítica, a cada 5 leituras em amostras, foi realizada uma nova calibração do eletrodo.

Assim como foi realizado nas medidas de $E_{H}$, o eletrodo de $\mathrm{pH}$ foi introduzido a cerca de $5 \mathrm{~cm}$ de profundidade na amostra, e foi observado que o tempo de estabilização das leituras é muito mais rápido que o anterior, cerca de 30 segundos. Sempre que se fez necessário, o eletrodo de $\mathrm{pH}$ foi limpo com uma solução de Extran $^{\otimes} 5 \%$ e em cas js de amostras muito gordurosas, o eletrodo foi mergulhado durante algumas horas em uma suspensão de pepsina a $5 \%$, preparada em $\mathrm{HCl} 0,1 \mathrm{M} .{ }^{(1)}$ Ao se observar qualquer enegrecimento do orifício, manteve-se o eletrodo em tiouréia por 2 horas e em seguida trocou-se o eletrólito interno do eletrodo, aguardand J-se 12 horas para ele estar novamente em condição de uso. 
Ao se encerrarem as leituras de $\mathrm{E}_{\mathrm{H}}$ e de $\mathrm{pH}$, removeu-se o filme de PVC e introduziu-se o batoque sob uma pressão de $\mathrm{N}_{2}$ (por cerca de 3 minutos) e uma tampa rosqueável. Pode-se desta forma, garantir que o frasco permaneceu pressurizado até as próximas leituras.

\section{7. determinaçáo de Sulfeto Ácido Volátil (SAV)}

Os métodos analíticos utilizados na determinação de SAV utilizam ácidos concentrados $\left(\mathrm{HCl}\right.$ ou $\left.\mathrm{H}_{2} \mathrm{SO}_{4}\right)$ diretamente na amostra e o produto (essencialmente $\mathrm{H}_{2} \mathrm{~S}$ ) é arrastado com gás inerte $\left(\mathrm{N}_{2}\right)$, para uma solução absorvedora apropriada para ions $\mathrm{S}^{2-(100)}$.

Neste trabalho, o estabelecimento da metodologia analítica adequada à determinação de SAV foi conduzido cumprindo-se as seguintes etapas: 1 estabelecer uma técnica analítica; 2 - otimizar as condiçōes de extração e 3 testar as condições mais favoráveis para amostras reais, como as do rio Tietê.

\subsection{1. estabelecimento da técnica analítica para SAV}

Neste trabalho, foram testadas 3 técnicas para a análise de sulfeto, a saber : Biamperometria com $\mathrm{I}_{2} / \mathrm{I}^{-}$, Polarografia de Pulso Diferencial e Potenciometria com Eletrodo Íon-Seletivo.

\subsubsection{1. biamperometria}

A biamperometria é uma técnica voltametrica que consiste na utilizaçăo de 2 eletrodos idênticos de Platina, entre os quais se aplica um pequeno potencial (p.e.100mV), e lê-se num galvanômetro a corrente que vai surgindo ao longo da análise. $O$ par $\mathrm{I}_{2} / l^{-}$é um do pares redox mais utilizados em biamperometria e segundo Valente ${ }^{(140)}$, esta técnica atende plenamente à determinação de sulfeto 
em amostras ambientais. A técnica descrita por este autor é de certa forma simples, o sulfeto presente na amostra é fixado numa solução de $\operatorname{Zn}(O A c)_{2}$, formando $\mathrm{ZnS}$, que em meio suficientemente ácido, gera o sulfeto volátil correspondente. Através de uma microbureta, adicionam-se volumes conhecidos de uma solução padrão de íons iodato, que reagem quantitativamente com $\mathrm{S}^{2-}$, como segue:

$$
3 \mathrm{I}_{2}+3 \mathrm{H}_{2} \mathrm{~S} \rightarrow 3 \mathrm{~S}^{\circ}+6 \mathrm{I}^{-}+3 \mathrm{H}_{2} \mathrm{O} \quad \text { eq. } 2.2
$$

Partindo-se do princípio que na realidade é o par $\mathrm{l}_{2} / l^{-}$que importa na reação, verifica-se que há um aumento na corrente lida quando se atinge o excesso de titulante. $O$ intercepto do segundo segmento de reta obtido indica o volume de equivalência da solução de ions iodato, que é o reagente limitante da reação.

Nas determinações biamperométricas deste trabalho, o equipamento utilizado foi um polarógrafo Sargent (manual) e um par de eletrodos idênticos de Pt. Um potencial de cerca de $100 \mathrm{mV}$ foi aplicado entre estes dois eletrodos.

\subsubsection{2. polarografia de pulso diferencial}

A determinação polarográfica de íons $\mathrm{S}^{2-}$ já é conhecida há pelo menos 60 anos, através dos trabalhos de Ravenda ${ }^{(141)}$, que atribuiu o fenômeno à oxidação dos íons $\mathrm{Hg}^{2+}$ e subsequente reação com os íons $\mathrm{S}^{2-}$, em solução. Esta reação e seu aproveitamento analítico veio a ser melhor esclarecido por Kolthoff e Miller ${ }^{(142)}$, tendo assim se firmado como método de determinação para íons $\mathrm{S}^{2-}$. A proposta de estudo de íons sulfeto por polarografia reside no fato de que há a forrmação de uma onda anódica, resultante do processo:

$$
\begin{aligned}
\mathrm{Hg} \rightarrow \mathrm{Hg}^{2+}+2 \mathrm{e}^{-} & \text {eq. } 2.3 \\
\mathrm{~S}^{2-}+\mathrm{Hg}^{2+} \rightarrow \mathrm{HgS} & \text { eq. } 2.4
\end{aligned}
$$


Os passos sugeridos de reação, segundo as equações 1 e 2 são a etapa oxidativa e a formação da camada insolúvel de sulfeto de mercúrio, respectivamente.

As determinações polarográficas foram realizadas num equipamento Metrohm mod. E-506 e uma célula polarográfica VA 663 Stand. O eletrodo de trabalho foi o eletrodo gotejante de mercúrio, o auxiliar de Pt e o de referência foi de $\mathrm{Ag} / \mathrm{AgCl}$.

Foi investigada também a potencialidade da polarografia de pulso diferencial na análise de sulfeto, como é apontada por alguns autores ${ }^{(144-146)}$. Neste estudo foi utilizado um polarógrafo Metrohm modelo E-506, com uma célula VA 663-Stand Metrohm, composta por um eletrodo gotejante de mercúrio, um eletrodo de referência de $\mathrm{Ag} / \mathrm{AgCl}$ e um eletrodo auxiliar de platina.

\subsubsection{3. potenciomentria com eletrodo ion-seletivo}

A determinação de AVS por eletrodo íon-seletivo é citada por diversos autores, como sendo de extrema versatilidade, além de apresentar elevada reprodutibilidade e sensibilidade ${ }^{(98,99)}$.

$\mathrm{Na}$ busca de uma metodologia analitica satisfatória para a determinação de AVS, utilizou-se um eletrodo de membrana sólida cristalina de $\mathrm{Ag}_{2} \mathrm{~S}$ desenvolvido por Serrano ${ }^{(147)}$. Há descrições caracteristicas para este eletrodo, tais como uma sensivel variação no potencial condicional do sistema $\left(E_{0}\right)$ e ainda uma resposta super-Nernstiana ( Slope $>32,0 \mathrm{mV} / \mathrm{pS}^{2-}$ ). Este eletrodo foi desenvolvido com uma membrana de $\mathrm{Ag}_{2} \mathrm{~S}$ de $50 \mathrm{~mm}$ de espessura, disposta em um tubo de teflon de 2 $\mathrm{cm}$ de diâmetro e o seu contato elétrico se dá por um fio de prata soldado. Juntamente com o eletrodo de membrana sólida, foi utilizado um eletrodo de referência de $\mathrm{Ag} / \mathrm{AgCl}$ Ingold, Xerolyt ${ }^{\Theta}$, não contaminável por íons $\mathrm{S}^{2-}$. As leituras foram realizadas num potenciômetro digital Micronal, mod. B-375, com precisão de $\pm 0,1 \mathrm{mV}$. As leituras de potencial deste eletrodo foram estáveis num tempo não superior a 3 minutos. 


\subsubsection{4. sistema de "geraçáo" de sulfeto ácido volátil (SAV)}

Simultaneamente à escolha da técnica analítica mais apropriada para a análise dos íons $\mathrm{S}^{2-}$, procedeu-se ao desenvolvimento do sistema de "geração" de SAV. Inicialmente foi preparada uma solução de ions sulfeto (1000 ppm de $\mathrm{S}^{2-}$ ), a partir da dissolução de $7,5043 \mathrm{~g}$ de $\mathrm{Na}_{2} \mathrm{~S} .9 \mathrm{H}_{2} \mathrm{O}$ (P.A. Merck) em $1000,0 \mathrm{~mL}$ de água deionizada, deaerada por 1 hora em $\mathbf{N}_{2}$. Após a transferência quantitativa do sal, o pH foi imediatamente ajustado para 12, com algumas lentilhas de $\mathrm{NaOH}$. Esta solução foi padronizada conforme é descrito por Vogel ${ }^{(148)}$. A concentração encontrada foi de $848 \mathrm{ppm}$ de $\mathrm{S}^{2-}$. Desta solução estoque, preparou-se uma solução de trabalho $(1: 1000), 0,85 \mathrm{ppm} .25,00 \mathrm{~mL}$ desta soluçãc foram transferidos para um tubo impinger de $40 \mathrm{~mL}$ (figura 3), adaptado a uma entrada de $\mathrm{N}_{2}$ e saída para o recipiente de análise. Foi adaptado uma mangueira de silicone com uma seringa hipodérmica plástica e através deste sistema introduziuse cerca de $15 \mathrm{~mL}$ de $\mathrm{HCl} 6 \mathrm{M}$, conforme é recomendado por Cornwell e Morse ${ }^{(149)}$. O sistema foi fechado imediatamente após a adição do ácido e após desconectar-se a seringa, introduziu-se uma conexão com $\mathbf{N}_{2}$, a fim de impulsionar o sulfeto volátil $\left(\mathrm{H}_{2} \mathrm{~S}\right)$ gerado no sistema. $\mathrm{O}$ gás foi recolhido numa solução absorvedora de íons $\mathrm{S}^{2-(100)}$. A figura 3 ilustra de forma simplificada o sistema de "geração" de SAV adotado neste trabalho: 


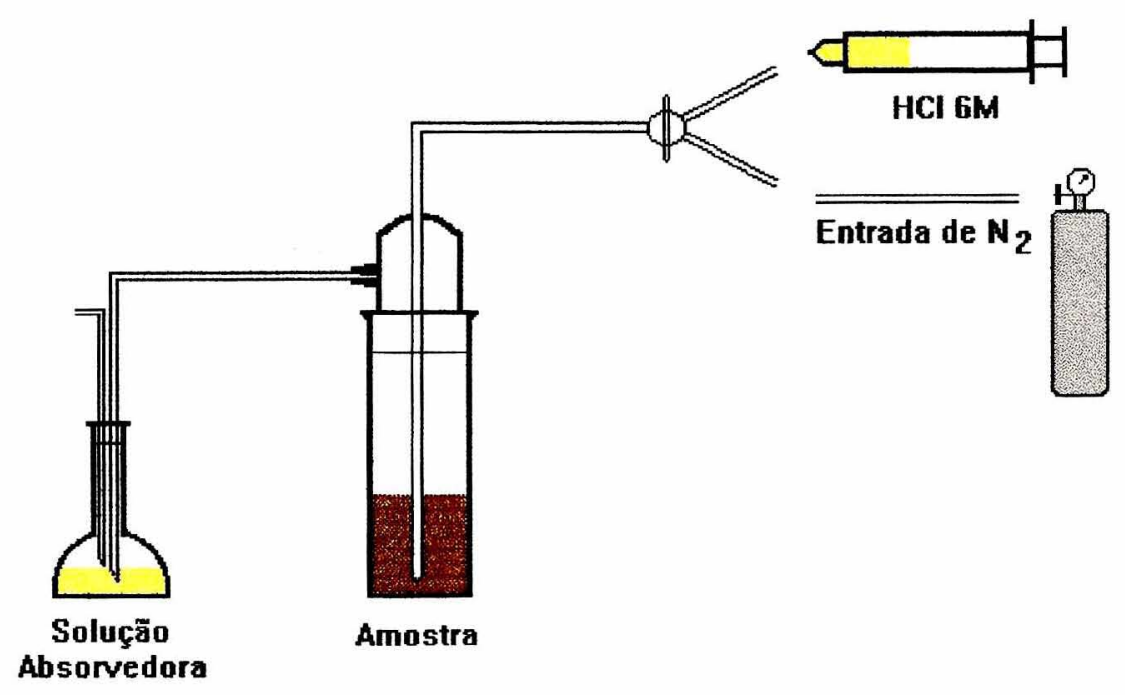

FIGURA 3: esquema simplificado do sistema "gerador" de SAV

Na determinação de sulfeto volátil das amostras de sedimentos, foi pesada uma quantidade (cerca de $150,0 \pm 0,1 \mathrm{mg}$ ) do material in natura, à temperatura ambiente, que foi transferida para o interior do impinger previamente tarado e em atmosfera de $\mathrm{N}_{2}$ (neste caso, a balança foi disposta no interior de um glove-bag, e a pesagem foi realizada numa pressão levemente positiva de $\mathrm{N}_{2}$ ). $\mathrm{O}$ sistema foi, neste caso, fechado ainda no interior do glove bag e levado para a extração. Simultaneamente, foram pesadas ainda 3 sub-amostras de sedimento para a determinação da sua massa seca, em cápsulas de porcelana previamente taradas, que foram levadas a uma estufa $\left(60^{\circ} \mathrm{C}, 96\right.$ horas). Esta temperatura foi adotada a fim de não se perder sulfeto da amostra por aquecimento. Foi 
verificada uma concordância de, no mínimo, $0,20 \%$, nos valores percentuais de massa obtidos.

Os ensaios em atmosfera controlada foram realizados num glove-bag atmosbag $^{\circledR}$, Aldrich. Foi verificado que devido à porosidade deste material, nitrogênio tende a sair rapidamente do seu interior, sendo assim necessário se trabalhar com uma leve pressão positiva do gás.

\section{8. determinação de metais pesados por Espectrofotometria de Absorção} Atômica

A técnica de absorção atômica foi utiłizada para a determinação dos seguintes elementos: $\mathrm{Cu}, \mathrm{Cd}, \mathrm{Cr}, \mathrm{Zn}, \mathrm{Pb}, \mathrm{Fe}, \mathrm{Ni}$ e $\mathrm{Mn}$. Um estudo recente tem demonstrado que estes metais estão presentes nos sedimentos do Tietê em concentrações significativamente elevadas ${ }^{(135)}$. Neste trabalho, objetivou-se determinar-se os níveis totais destes metais, bem como a forma química que se encontram associados nos sedimentos e ainda estimar a biodisponibilidade que apresentam.

As determinações foram realizadas em um espectrofotômetro de absorção atômica Perkin Elmer, modelo 3110, com correção de lâmpada de deutério. As condições analíticas adotadas estão descritas a seguir:

TABELA 2 - Condições analíticas adotadas na determinação dos metais pesados das amostras de sedimento do Tietê, por espectrofotometria de absorção atômica

\begin{tabular}{|l|l|l|l|l|l|l|l|l|}
\hline \multirow{2}{*}{ Condições } & \multicolumn{9}{|l|}{ Elemento } & $\mathbf{C r}$ & $\mathbf{C d}$ & $\mathbf{P b}$ & $\mathbf{Z n}$ & $\mathbf{N i}$ & $\mathbf{F e}$ & $\mathbf{M n}$ \\
\cline { 2 - 10 } & $\mathbf{C u}$ & $\mathbf{C r}$ & 248.3 & 279.5 \\
\hline$\lambda(\mathbf{n m})$ & 324.8 & 357.9 & 228.8 & 283.3 & 213.9 & 341.5 & 248.3 \\
\hline Lâmpada/i(mA) & $\begin{array}{l}\text { L.C.O., } \\
10\end{array}$ & $\begin{array}{l}\text { L.C.O.. } \\
25\end{array}$ & $\begin{array}{l}\text { E.D.L., } \\
170\end{array}$ & $\begin{array}{l}\text { E.D.L., } \\
360\end{array}$ & $\begin{array}{l}\text { E.D.L.. } \\
200\end{array}$ & $\begin{array}{l}\text { L.C.O., } \\
30\end{array}$ & $\begin{array}{l}\text { L.C.O., } \\
18\end{array}$ & $\begin{array}{l}\text { L.C.O., } \\
12\end{array}$ \\
\hline Queimador & premix & premix & spoiler & spoiler & premix & premix & premix & premix \\
\hline Fenda & 0.7 & 0.7 & 0.7 & 0.7 & 0.7 & 0.2 & 0.2 & 0.7 \\
\hline $\begin{array}{l}\text { Mistura } \\
\text { ar/acetileno }\end{array}$ & $3: 1$ & $4: 1$ & $3: 1$ & $3: 1$ & $5: 1$ & $3: 1$ & $3: 1$ & $4: 1$ \\
\hline
\end{tabular}


Vale ressaltar que toda a vidraria, bem como recipientes plásticos e de teflon foram previamente acondicionados e lavados $\left(\mathrm{HNO}_{3} 30 \%\right.$, 1 semana, água destilada e deionizada) conforme as recomendações de Batley e Gardner ${ }^{(150)}$, para a determinação de metais em amostras de água e de sedimento. Procedeuse à determinação dos brancos em paralelo às amostras. Os padrões do metais foram preparados com soluções Titrisol ${ }^{\otimes}$ Merck, a partir da diluição de soluções estoque de $1000 \mathrm{mg} / \mathrm{L}$. As curvas foram construídas com esses padrões na faixa de concentração de 0,$5 ; 1,0 ; 1,5$ e 2,0 ppm, respectivamente e em meio de $\mathrm{HCl}$ $(\mathrm{pH}=1)$. $\mathrm{O}$ valor aceito de cada leitura foi baseado no valor médio de três leituras simultâneas, com desvio não superior a $0,1 \%$. No caso das determinações das amostras provenientes do método de extração sequencial, cada curva foi construída com padrão do metal e a quantidade correspondente do reagente utilizado na respectiva etapa de extração. Este procedimento é conhecido como "match matrix" e visa eliminar o efeito de matriz causado pela excessiva concentração de reagente nas medidas em absorção atômica. ${ }^{(10)}$

No decorrer das medidas, procedeu-se à limpeza do queimador, sempre que foram observadas interferências no sinal analítico, tais como perdas no sinal e a presença visual de resíduos na chama.

\subsection{1. método de extração sequencial}

A fim de se estimar a distribuição dos metais pesados nas diversas fases que compõem o sedimento, foi aplicado o método de extração sequencial nas amostras de sedimentos do rio Tietê. Devido à natureza das amostras estudadas, que são provenientes de ambientes anóxidos em sua maioria, optou-se pelo método proposto por Kersten e Förstner ${ }^{(35,36)}$, que sugere que as extrações sejam realizadas em atmosfera controlada. Vale ressaltar que este procedimento é o único encontrado na literatura que expressa uma sensivel preoupação na manutenção das condições originais da amostra durante a extração e consequentemente a sua integridade anaeróbica. Isto se enquadra ${ }_{46}$ 
significativamente bem na proposta de estudo do rio Tietê, que apresenta condições anóxidas nos trechos mais críticos de contaminação. Kersten e Förstner têm demonstrado que caso a extração de metais de amostras anóxidas seja conduzida ao ar livre, as frações iniciais apresentarão resultados mais elevados, não condizendo com a situação real da amostra. ${ }^{(16,35-36)}$ Vale salientar que os experimentos descritos por estes autores no Rio Elba, sul da Alemanha, mostram condições significativamente semelhantes às encontradas nas amostras do Tietê, ambiente de estudo deste trabalho, conforme será mostrado adiante.

Em nossos estudos, as amostras de sedimentos foram pesadas no interior de um glove-bag, sob pressão levemente positiva de $\mathrm{N}_{2}$. Foram aplicadas, no mínimo, 3 cargas de gás até a expulsão do ar remanescente no interior do glo jebag. As extrações foram realizadas em frascos de Pirex ${ }^{\circledR}$ Schoot (capacidade de $80 \mathrm{~mL}$ ), com tampa rosqueável e batoque interno, a fim de não expor em nenhum instante as amostras ao oxigênio do ar.

Em cada pesagem, uma porção da amostra (5 a $10 \mathrm{~g}$.) foi retirada do centro do frasco de sedimento, com uma colher de polietileno. Procurou-se manter uma proporção entre volume do reagente de extração : massa seca de sedimento ao

redor de 20:1, conforme é recomendado pelos autores. Para cada ponto estudado, foram realizadas extrações em triplicata. O manuseio das amostras durante as quatro etapas iniciais de extração foi realizado no interior de um glovebox (Labconco), em linha de $\mathrm{N}_{2}$ ( grau $\mathrm{R}$, Oxigênio do Brasil). $\mathrm{O}$ gás foi purificado com solução de sulfato de vanádio em amálgama de $\mathrm{Zn}$, e seco com $\mathrm{H}_{2} \mathrm{SO}_{4}$, antes de alimentar a câmara. $O$ procedimento adotado na alimentação da câmara foi: 1 - uma pressão baixa o suficiente para que as luvas fossem recolhidas totalmente para o interior da câmara; 2 - pressão positiva de $\mathrm{N}_{2}$, até que as luvas saissem totalmente do interior da câmara. Estas operações foram repetidas, pelo menos 3 vezes, até renovar-se suficientemente a atmosfera de $\mathrm{N}_{2}$. As soluções de extração $\left(\mathrm{NH}_{4} \mathrm{OAc} / \mathrm{HOAc} / \mathrm{NaOAc}, \mathrm{NH}_{2} \mathrm{OH}\right.$. $\mathrm{HCl}$ e tampão $\left.\mathrm{H}_{2} \mathrm{C}_{2} \mathrm{O}_{4} / \mathrm{NH}_{4} \mathrm{C}_{2} \mathrm{O}_{4}\right)$ foram deaeradas com $\mathrm{N}_{2}$ durante, pelo menos, 90 minutos antes de serem adicionadas às amostras de sedimento. $O$ procedimento de extração sequencial adotado nestetrabalho está descrito no diagrama na página seguinte: 


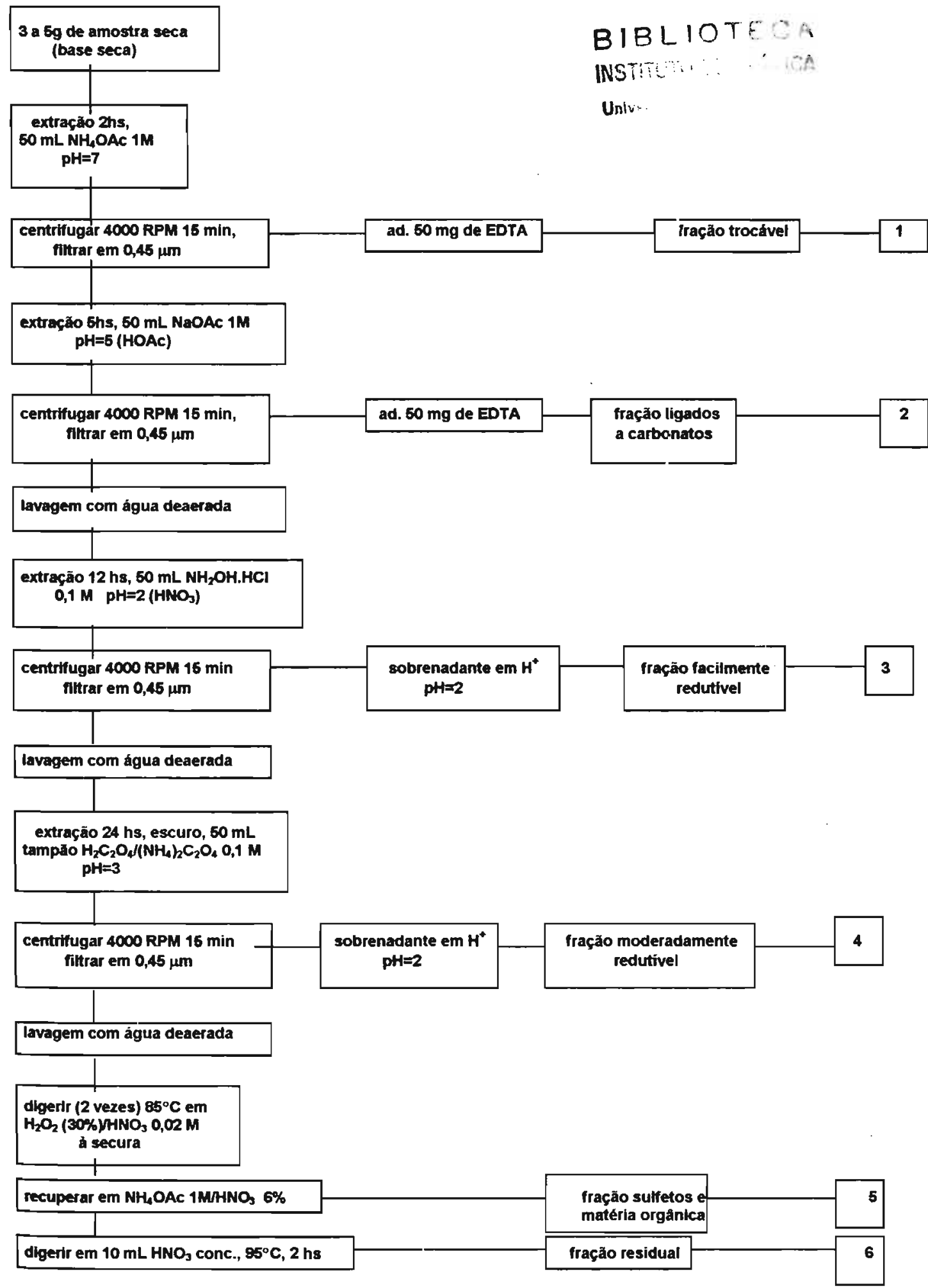

FIGURA 5: esquema do metodo de ixtração sequencial de Kersten e Forstner, utilizado nas amostras de sedimentos do rio Tietê 
Os passos de cada etapa de extração estão apresentados abaixo:

fracão trocável: Cada sub-amostra do sedimento anóxido foi dividida em duas metades. Uma metade foi conduzida para a uma estufa à vácuo a fim de se determinar o conteúdo sólido do sedimento (em triplicata) e a outra metade foi transferida para o recipiente de extração, conforme já explanado acima. Foram adicionados $50 \pm 0,5 \mathrm{~mL}$ de uma solução de $\mathrm{NH}_{4} \mathrm{OAc}$ com pH ajustado em 7 e esta suspensāo foi agitada por 2 horas em um agitador horizontal New Brunswick, à temperatura ambiente, com uma rotação de 200 RPM. Após cessar a agitação, a suspensão fci mantida em repouso por um tempo considerado suficiente para se separar as duas fases. Em seguida, os frascos foram conduzidos ao interior do "glove-box", aonde se realizou cuidadosamente a transferência do sobrenadante para um tubo de centrifuga (Corning) de polipropileno, com capacidade de $50 \mathrm{~mL}$ e com tampa rosqueável. A transferência do líquido foi realizada com o auxilio de uma seringa plástica hipodérmica de 20 $\mathrm{mL}$, com uma adaptação de uma ponta de teflon. Com isso, perdas insignificantes foram verificadas durante esta operação. Após a transferência, o tubo foi retirado da câmara, e conduzido para uma centrífuga, aonde foi submetido a uma rotação de 4000 RPM, durante 20 minutos. Após a centrifugação, o tubo foi retornado para o interior da câmara e o sobrenadante líquido foi filtrado numa seringa hipodérmica adaptada a uma membrana filtrante $0,45 \mu \mathrm{m}$ (purgada em $\mathrm{N}_{2}$ ), e transferido para um frasco de polietileno. Cerca de $50 \mathrm{mg}$ de EDTA foram adicionados para se prevenir a precipitação de ferro durante a estocagem desta fração e o frasco foi mantido sob refrigeração $\left(4^{\circ} \mathrm{C}\right)$ até 0 momento da determinação dos metais.

fração ligada a carbonatos. Ao resíduo sólido da fração anterior, foram adicionados $50,0 \pm 0,5 \mathrm{~mL}$ de uma solução de NaOAc (1M), tamponada com HOAc (1M), resultando num tampão de $\mathrm{pH} 5$ e agitada por $5 \mathrm{hs}$, a $200 \mathrm{RPM}$. 
As etapas de centrifugação, filtração e transferência foram idênticas às descritas acima, inclusive a adição de EDTA $(50 \mathrm{mg})$.

fracão facilmente redutível. O resíduo sólido da etapa anterior foi lavado uma vez com água deionizada e livre de $\mathrm{O}_{2}$, a fim de reduzir os efeitos negativos causados pelo efeito tampão na etapa seguinte. Ao resíduo sólido foram adicionados 50,0 \pm $0,5 \mathrm{~mL}$ de uma solução de $\mathrm{NH}_{2} \mathrm{OH} . \mathrm{HCl}, 0,01 \mathrm{M}$ e manteve-se este frasco sob agitação por um período de 12 horas.

fracão moderadamente redutível. O resíduo da etapa anterior foi extraído com tampão oxalato $(0,1 \mathrm{M}) \mathrm{em} \mathrm{pH} \mathrm{3,} \mathrm{por} 24$ horas. Após esta extração, o resíduo foi lavado com água deionizada livre de $\mathrm{O}_{2}$ e procede-se às próximas extrações em ambiente aberto.

fração de sulfetos e matéria orgânica. A fim de promover um ataque aos componentes oxidáveis do sedimento, o resíduo lavado foi digerido duas vezes com $\mathrm{H}_{2} \mathrm{O}_{2} 30 \%$, em $\mathrm{HNO}_{3} 0,02 \mathrm{M}$, a uma temperatura de $85^{\circ} \mathrm{C}$, até a secura. Em seguida, o resíduo foi tratado com $\mathrm{NH}_{4} \mathrm{OAc} 1 \mathrm{M}$, em $\mathrm{HNO} 36 \%$, durante um período de 12 horas, a fim de recuperar os metais eventualmente adsorvidos nos sítios de adsorção do sedimento ${ }^{(16)}$.

fração residual. O resíduo lavado da etapa anterior foi atacado com 10,0 $\pm 0,5 \mathrm{~mL}$ de $\mathrm{HNO}_{3}$ a $95^{\circ} \mathrm{C}$, por 2 horas, evaporado até quase a secura. $\mathrm{O}$ material é lavado com algumas porções de água deionizada e a fração dissolvida foi separada dos sólidos por centrifugação, a 4000 RPM, por 20 minutos.

A concentração total dos elementos foi estimada a partir de um ataque com $\mathrm{HNO}_{3} / \mathrm{H}_{2} \mathrm{O}_{2} 2: 1$, que segundo Kersten e Förstner, atende plenamente a esse tipo de estudo. 


\subsection{2. metais totais e biodisponibilidade}

As aberturas ou ataques totais das amostras de sedimentos foram realizadas utilizando-se o método de bomba de teflon e o método de microondas. O esquema abaixo ilustra as operações realizadas nesta etıapa:
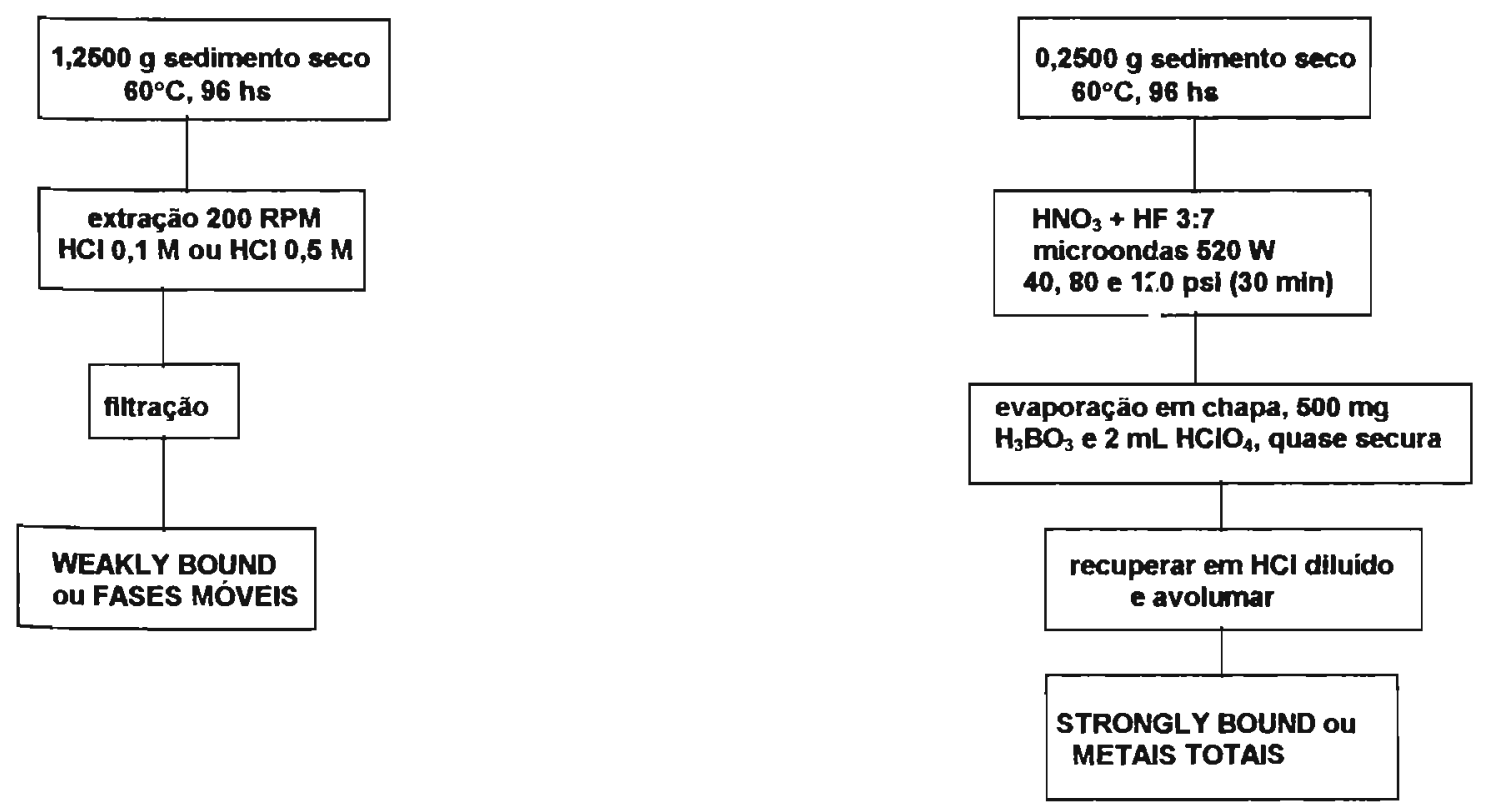

FIGURA 6: Fluxogramas correspondentes à extração em ácido diluído e abertura total

$\mathrm{Na}$ abertura por bomba de teflon, uma massa exatamente conhecida (cerca de $0,2500 \mathrm{~g}$ ) do sedimento seco e finamente dividido foi pesada no interior de um recipiente de teflon com tampa e em seguida foi adicionada cuidadosamente uma mistura de $\mathrm{HNO}_{3}$ e $\mathrm{HF}$ (3:7). O recipiente foi fechado e disposto no interior de um cilindro de aço, com rosca e mola de segurança, caso a pressão do interior do bloco uiltrapasse um certo valor crítico de pressão. O conjunto foi levado para uma mufla, a $150^{\circ} \mathrm{C}$, por um periodo de 6 horas. Após este periodo, deixou-se o conjunto esfriar e a amostra foi cuidadosamente transferida para um cadinho de 
teflon, aonde se prosseguiu $O$ ataque da amostra em chapa quente, com a adição de $2 \pm 0,5 \mathrm{~mL}$ de $\mathrm{HClO}_{4}$ (P.A., Merck) e cerca de $500 \mathrm{mg}$ de ácido bórico (P.A., Merck), a fim de solubilizar-se o alumínio presente na amostra, além dos fluoretos insolúveis ${ }^{(151,152)}$. A mistura foi levada até quase a secura e retomada em $\mathrm{HCl}$ até evaporar o remanescente. Quando não se observou mais a presença de resíduos, o aquecimento foi interrompido e após resfriar a solução, transfere-se para um balão volumétrico de 25,00 ou de $50,00 \mathrm{~mL}$.

$O$ ataque por microondas foi realizado num equipamento CEM modelo 2000 , com $650 \mathrm{~W}$ de potência, carrossel com espaço para 12 frascos e dispositivos de segurança de alívio de pressão. Foi utilizada neste ataque uma mistura ácida de $\mathrm{HNO}_{3}, \mathrm{HF} \mathrm{e} \mathrm{HCl}$ e o tempo de reação foi de cerca de 25 minutos. Este tempo foi estimado com base no comportamento da mistura, mostrado no gráfico da pressão $x$ temperatura, registrado pelo equipamento. Praticamente não são verificados resíduos após este ataque. Após um tempo de resfriamento, a amostra foi transferida para um bequer de teflon e procedeu -se de forma semelhante ao item anterior. As aberturas foram realizadas em triplicatas.

A determinação analítica da fração potencialmente "biodisponivel" dos metais pesados presentes nas amostras de sedimentos fo realizada a partir da pesagem de uma quantidade exata de amostra (cerca de1,2500g) finamente pulverizada e seca a $60^{\circ} \mathrm{C}$, por $96 \mathrm{hs}$, no interior de um recipiente de polietileno limpo de $250 \mathrm{~mL}$, com tampa rosqueável e batoque interno. Em seguida, foram adicionados com uma pipeta volumétrica $25,00 \mathrm{~mL}$ de uma solução de $\mathrm{HCl}$ (foram testadas as concentrações de 0,1 e $0,5 \mathrm{M}$ ) e esta suspensão foi agitada por 2 horas em um agitador horizontal New Brunswick, à temperatura ambiente, com uma rotação de 200 RPM. Em seçuida, a suspensão foi deixada em repouso até o material sólido sedimentar, procedendo-se em seguida a uma filtração em papel de filltração rápida. O filtrado foi mantido sob refrigeração a $4^{\circ} \mathrm{C}$, até a determinação dos metais. 


\section{9. análise granulométrica}

A análise granulométrica, ou a determinação concernente ao tamanho de grãos foi conduzida seguindo-se o critério recomendado por Ackermann et al. ${ }^{(111)}$, que sugere a utilização de ultrassom durante o peneiramento à úmido, a fim de promover uma maior desagregação das partículas.

As amostras de sedimentos destinadas à análise granulométrica foram secas a $110^{\circ} \mathrm{C}$ por um período de 2 horas e mantidas em um dessecador até a pesagem. No peneiramento foi utilizado um conjunto de peneiras de teflon, com malha de nylon ( $<200 \mu \mathrm{m},<63 \mu \mathrm{m}$ e $<20 \mu \mathrm{m}$, respectivamente). A peneira de malha correspondente a $<200 \mu \mathrm{m}$ foi utilizada com o intuito de remover todo material grosseiro que pudesse interferir na análise, como galhos de árvore, folhas, pedregulhos, etc. Após esta pré-seleção dos grãos, a amostra foi pesada diretamente $(10,00 \pm 0,01 \mathrm{~g})$ na peneira previamente tarada $(<63 \mu \mathrm{m})$, que foi levada para o interior de um frasco plástico de $2 \mathrm{~L}$, preenchido com cerca de 200 $\mathrm{mL}$ de água destilada, que por sua vez foi disposto no interior de um banho ultrassônico. O peneiramento foi realizado durante um período de 15 minutos e pôde-se verificar que este tempo foi suficiente para todo o material ser peneirado. Os autores sugerem o uso de pérolas de vidro para auxiliar no peneiramento, que em nossas observações, não trouxeram nenhuma vantagem na análise. Após essa operação, a peneira foi parcialmente seca com algumas porções de acetona e em seguida com fluxo de $\mathrm{N}_{2}$. Por último, a peneira foi disposta num dessecador à vácuo, numa temperatura de $45^{\circ} \mathrm{C}$ e deixada por várias horas para ser pesada. Procedeu -se da mesma forma com a peneira $<20$ $\mu \mathrm{m}$, a fim de se conhecer esta fração presente na amostra.

$O$ valor da fração $<63 \mu \mathrm{m}$ foi obtido a partir de uma subtração do valor $<20 \mu \mathrm{m}$.

Foram realizadas um total de 3 determinações para cada amostra e o desvios não foram superiores a $10 \%$. 


\subsection{0. análise textural}

A análise textural foi realizada pela técnica de microscopia eletrônica de varredura com energia dispersiva de raio-X (MEV-EDX), que permite que se obtenha ao mesmo tempo a imagem da textura da amostra (também denominada micrografia) e simultaneamente o espectro com os picos correspondentes aos elementos químicos presentes.

As análises por microscopia eletrônica de varedura foram realizadas em agregados de amostras secas (sem peneiramento), metalizados com uma fina camada de carbono, que serviu como condutor de elétrons. O equipamento (microscópio eletrônico de varredura JEOL, modelo JSM - T 330-A), dotado de uma câmara de imagens, está acoplado a um microcomputador, que compara os resultados da amostra de sedimentos com uma série de padrões geológicos. Essas análises foram realizadas no NUPEGEL do Instituto Astronômico e Geofísico da USP.

\subsection{1. análise de carbono total}

As análises de carbono total foram realizadas na central analítica do IQUSP. Foi utilizado um analisador elementar (CHN) Perkin-Elmer. As amostras foram subdivididas seguindo o seguinte critério: Uma porção seca e homogênea foi enviada para a determinação de Carbono total, e a outra porção foi tratada por 12 horas com $\mathrm{HCl} 2 \mathrm{M}$, com agitação mecânica, a fim de se eliminar os eventuais carbonatos presentes na amostra de sedimento. Com isso, pode-se determinar os niveis de Carbono orgânico e inorgânico presentes na amostra. 


\subsection{2. isolamento e caracterização de ácidos húmicos}

A extração do ácido húmico presente na porção orgânica dos sedimentos foi realizada no Laboratório de Radicisótopos do Instituto de Química de São Carlos - USP. Esta extração se deu a partir do método tradicional de isolamento de substâncias húmicas, que consiste em tratar a amostra de sedimento com uma solução concentrada de $\mathrm{KOH}$, deixando o material não húmico precipitar por algumas horas. $\mathrm{O}$ sobrenadante, é tratado em seguida com ácido clorídrico até precipitar a fração húmica, e este traíamento é repetido sucessivas vezes até se isolar um sólido escuro, que é o ácido húmico de interesse. $O$ material resultante é centrifugado a 4500 RPM por 10 minutos e seco em estufa a $60^{\circ} \mathrm{C}$, por várias horas. As análises elementares (CHN) foram realizadas num analisador elementar Perkin Elmer, pertencente à Central Analítica do IQUSP.

A análise qualitativa por espectrofotometria UV-VIS foi realizada em um equipamento Beckman modelo DU-70 com duplo feixe. Os espectros de UV-VIS foram obtidos a partir da dissolução de cerca de $10 \mathrm{mg}$ do material em solução de $\mathrm{NaOH}$ com $\mathrm{pH}=10$. 


\section{RESULTADOS E DISCUSSÃO}

\section{1. estudo da estabilidade das amostras através das medidas de $E_{H}$ e de $\mathrm{pH}$.}

As determinações de $\mathrm{E}_{\mathrm{H}}$ e de $\mathrm{pH}$ foram realizadas tanto para se conhecer os potenciais redox das amostras, definidos operacionalmente como $\mathrm{E}_{\mathrm{H}}$, quanto para se estimar a estabilidade das mesmas, mantidas em condições anóxidas. Acredita-se em tese que, desde que a amostra não seja exposta ao ar, ela pode manter-se em condições muito semelhantes às amostras de um ambiente natural, pouco perturbado. Isto equivale a dizer que uma amostra conservada nas condiçōes sugeridas neste trabalho pode permanecer guardada por longos períodos, at ś ser analisada. Verifiquemos os resultados obtidos no período de 01/93 a 01/96, que são apresentados na tabela 3:

TABELA 3: Resultados de $\mathrm{E}_{\mathrm{H}}$ e de $\mathrm{pH}$ observados para as amostras do Rio Tietê nos anos de 93,94 e 95 .

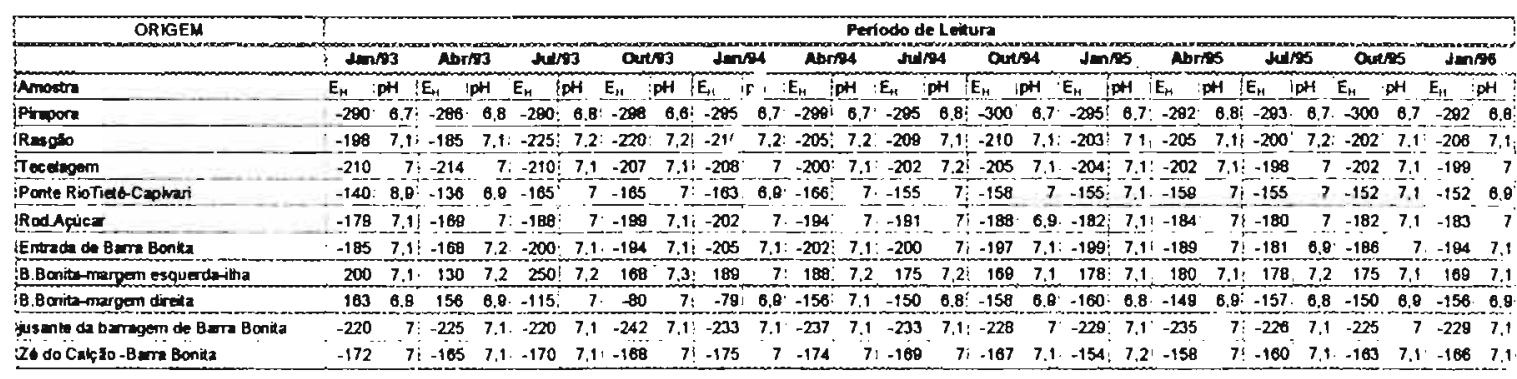

Os valores de $\mathrm{E}_{\mathrm{H}}$ e de $\mathrm{pH}$ na tabela acima, estão apresentados trimestralmente a fim de facilitar a tabulação desses resultados.

Pode-se verificar na tabela acima que a maioria das amostras de sedimentos estudadas apresenta:am resultados significativamente satisfatórios no que diz respeito à manutenção das condições originais de amostragem, tanto para $\mathrm{E}_{\mathrm{H}}$, quanto para $\mathrm{pH}$.

Wood ${ }^{(139)}$ considera que o grau de contaminação de uma determinada amostra governará a sua resisiência à mudança de seu potencial redox, num efeito análogo à capacidade tampão de um sistema. De fato, em uma amostra 
efeito análogo à capacidade tampão de um sistema. De fato, em uma amostra com característica redutora, estabelece-se uma camada anóxida natural (principalmente de sulfeto de ferro amorfo) que propicia uma proteção às camadas mais interiores, dificultando assim a difusão do oxigênio do ar. Nesse sentido, pode-se considerar que a preservação das amostras do Tietê em atmosfera de $\mathrm{N}_{2}$ é, na realidade, uma garantia a mais para a conservação dessas amostras ao longo do tempo.

As variações de $E_{H}$ verificadas nas amostras de sedimentos do Tietê durante o período de estudo de tres anos estão dentro de uma margem de tolerância de 10 a $30 \mathrm{mV}$, a mesma encontrada por Whitfield ${ }^{(52)}$, que foi estimada a partir de experimentos realizados em lamas anóxidas. Segundo este autor, somente variações superiores a $50 \mathrm{mV}$ sugerem mudanças significativas em termos de variação do potencial redox da amostra. Os resultados observados por nós ao longo deste período de estudo estiveram sempre muito abaixo desse intervalo.

Ainda com relação à precisão das medidas de $\mathrm{E}_{\mathrm{H}}$, um estudo realizado por Barcelona et al. ${ }^{(160)} \mathrm{em}$ amostras de águas interiores $(\mathrm{N}=234)$ durante um período de 2 anos, revelou desvios da ordem de $\pm 22 \mathrm{mV}$, concordando também com os resultados do Tietê.

As pequenas variações de $E_{H}$ observadas para as amostras de sedimentos do Tietê efetuadas no decorrer do tempo, podem ser atribuidas a uma condição particular da matriz, semelhantemente ao fenômeno apresentado pelos potencial condicional do sistema. Essas veriações, normalmente de alguns milivolts, são pertinentes à condição de medida, e não podem ser atribuidas às variações do sistema químico em si, pois as medidas efetuadas estão dentro do desvio de \pm 30 $\mathrm{mV}$. Portanto, pequenas variações observadas não invalidam os resultados experimentais. 
Com relação à medida de $\mathrm{pH}$ não foram verificados desvios como os das medidas de $E_{H}$.

Devido as características deste experimento, é prudente considerar que os resultados das leituras de $E_{H}$ devam ser tratados num contexto estritamente operacional, válido somente nas condições particulares de medida, embora se tenha condições de reversibilidade na matriz.

Ainda com relação às medidas de $E_{H}$, algumas anomalias foram verificadas. A amostra referente à margem esquerda de Barra Bonita (tabela 3 ), cujo valor de $E_{H}$ foi de $+200 \mathrm{mV}$, apresentou uma variação muito grande de valores durante o período de estudo de 3 neses $( \pm 70 \mathrm{mV})$, provavelmente por ter sido conservada em atmosfera de $\mathrm{N}_{2}{ }^{(16)}$. No entanto, essa hipótese não pôde ser confirmada, pois não foram levantados os valores de $E_{H}$ desta mesma amostra mantida em sua atmosfera natural.

Foi observado também que a amostra referente à margem direita de Barra Borita apresentou no período inícial das medidas (Janeiro/93 e março/93, respectivamente) valores positivos de $E_{H}$, que se tornaram negativos ao longo do tempo. Este fenômeno foi definido por Kersten e Förstner ${ }^{(16)}$ como "indução anóxida", causado pela ausência de $\mathrm{O}_{2}$ e presença de bactérias, que provavelmente propiciou o crescimento de microorganismos capazes de reduzir quimicamente algumas espécies, tais como íons sulfato a ions sulfeto e ions férricos a íons ferrosos ${ }^{(154)}$. O resultado observado para esta amostra nos leva a considerar que deve-se manter as amostras óxidas sem pressurização de $\mathbf{N}_{2}$, a fim de se evitar que reações pertinentes a ambientes anóxidos se desenvolvam neste tipo de amostra.

Diante dos resultados encontrados neste estudo, confirma-se a hipótese lançada anteriormente em tese, de que em condições favoráveis de conservação, amostras anóxidas podem manter suas condiçōes originais de coleta.

Apesar da recomendação encontrada no ASTM-APHA ${ }^{(57)}$, de que amostras 
não podem ser estocadas por longos períodos, em nossos estudos, com o rigor dispensado para amostras em condições redutoras, como as do Tietê, pode-se perfeitamente conservá-las garantindo-se assim suas condições originais. As medidas de $E_{H}$ e pH mostraram-se bons guias de orientação de condições amostrais e de preservação e portanto, ao nosso ver se enquadram no protncolo de procedimentos para análise de sedimentos. Deve-se frisar que este estudo apresenta um certo grau de ineditismo, devendo-se, portanto ser considerada a sua importante contribuição para os estudos de sedimentos. Ressalte-se a sua importância pelo fato que numa campanha de coleta de sedimentos, nem sempre se pode analisar as amostras assim que são recolhidas. No entantc, em condições controladas, pode-se programar uma melhor distribuição de trabalho.

\section{2. determinação de sulfeto ácido volátil por biamperometria}

O método foi inicialmente testado com a solução padrão de íons sulfeto (ver item 2.7.1.1.). Desta solução estoque, foi preparada uma solução de trabaho (1:1000), com concentração de $0,85 \mathrm{ppm}$. Foram transferidos $25,00 \mathrm{~mL}$ desta solução para um tubo impinger de $40 \mathrm{~mL}$, adaptado a uma entrada vertical de gás e saída para o recipiente de análise (figura 2). Em seguida, adaptou-se um tubo de silicone ligado a uma seringa hipodérmica plástica, através do qual foram introduzidos $15 \mathrm{~mL}$ de $\mathrm{HCl} 6 \mathrm{M}$, conforme é sugerido por Cornwell e Morse ${ }^{(149)}$. Após a adição do ácido, fechou-se imediatamente o sistema e introduziu-se uma conexão com $\mathrm{N}_{2}$, para impulsionar o $\mathrm{H}_{2} \mathrm{~S}$ gerado. Este gás foi recolhido diretamente na célula de análise com $25 \mathrm{~mL}$ de solução de $\mathrm{Zn}(\mathrm{OAc})_{2}$ e hermeticamente fechada. Foi realizado o arraste por um período de 45 minutos, tempo suficiente para que todo $\circ \mathrm{H}_{2} \mathrm{~S}$ gerado fosse recolhido na solução. Promoveu-se em seguida a deaeração desta solução por 10 minutos e após esta etapa foram adicionados $1,25 \mathrm{~mL}$ de $\mathrm{H}_{2} \mathrm{SO}_{4} 9 \mathrm{M}$ e uma ponta de espátula de $\mathrm{KI}$ $(0,10 \mathrm{~g})$, suficiente para gerar $\mathrm{I}_{2}$ na reação. Deaerou-se novamente a solução 
por mais 5 minutos, desconectou-se o gás e zerou-se o galvanômetro. Com a microbureta, foram iniciadas adições de pequenos volumes da solução de $\mathrm{IO}_{3}$, com concentração de $5.10^{-4} \mathrm{M}$, conforme recomendação de Valente. ${ }^{(140)} \mathrm{A}$ cada incremento, foram aguardados alguns segundos para a estabilização da corrente

A figura 6 mostra uma curva típica obtida por esta técnica:

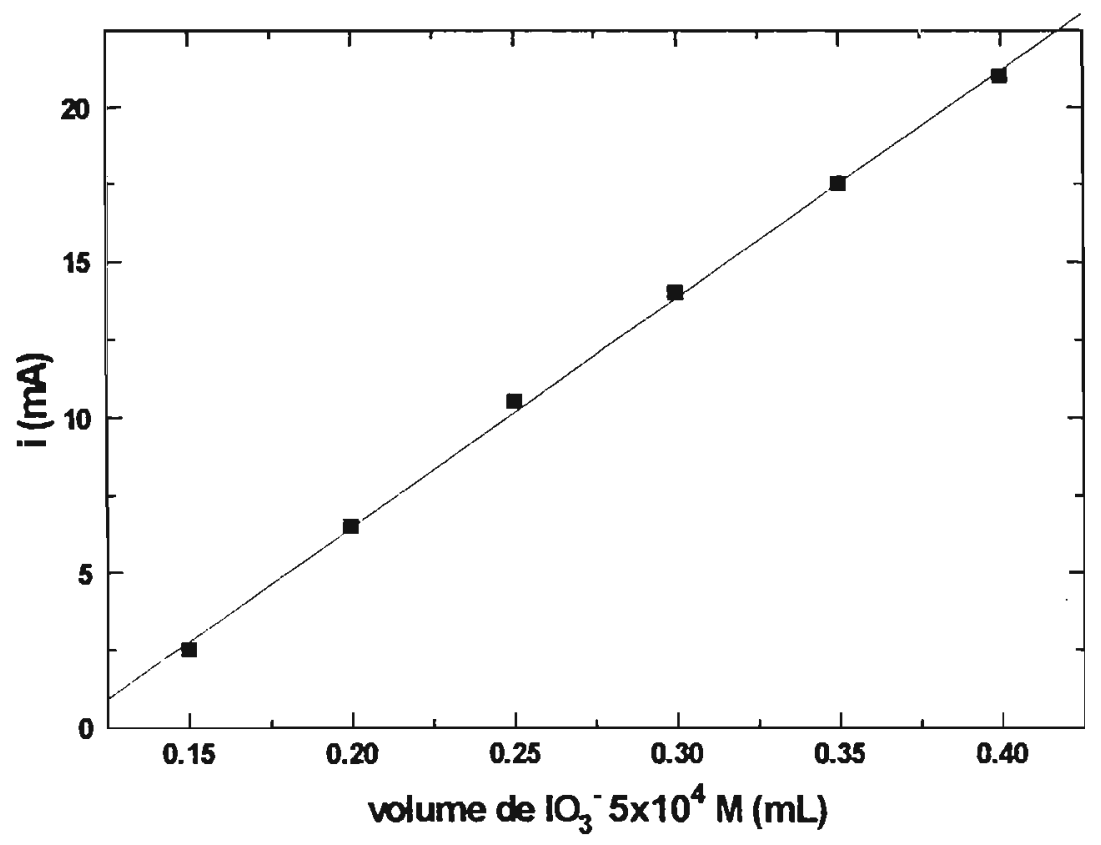

FIGURA 6: curva típica obtida na determinação biamperométrica de sulfeto $\operatorname{com~I} / I^{-}$

As porcentagens de reluperação obtidas foram de 23,25 e $31 \%$, respectivamente. Acreditando-se que o problema estivesse ocorrendo no sistema "gerador" de SAV, foi adaptado um balão de 3 bocas de $125 \mathrm{~mL}$ com um funil de $50 \mathrm{~mL}$ para a adição do ácido. Os resultados encontrados foram de 32, 36, 21 e 
$24 \%$, respectivamente. Verificou-se desta forma que a baixa recuperação de ions $\mathrm{S}^{2-}$ não se deve às perdas ocorridas no sistema "gerador" de SAV, mas sim a problemas na célula de análise (será mostrado posteriormente que o sistema gerador é extremamente satisfatório para a proposta de estudo de SAV).

A fim de se esclarecer os problemas de recuperação verificados na determinação biamperométrica, decidiu-se por adicionar diretamente na célula voltamétrica uma porção de íons $\mathrm{S}^{2-}$, a fim de verificar a possivel ocorrência de problemas advindos da reação química entre $\mathrm{I}_{2}$ e $\mathrm{S}^{2-}$. Foi adicionado um volume correspondente a exatamente $0,025 \mathrm{mg}_{\text {de } \mathrm{S}^{2-}}$ e a análise foi realizada conforme descrita pelo autor ${ }^{(140)}$. Os resultados encontrados foram de 31 e $30 \%$, respectivamente. Isto vem a confirmar a hipótese levantada anteriormente, de estar havendo problemas associados à reação química. Verifica-se que cerca de $70 \%$ do sulfeto adicionado à célula não reage com $\mathrm{I}_{2}$, pois o volume de $\mathrm{IO}_{3}{ }^{\circ}$ é muito inferior ao esperado. Outra hipótese a ser considerada seria a formação de $\mathrm{I}_{2}$ por oxidação do ar, pois o meio está muito ácido e portanto significativamente favorável para esta reaçăo. No entanto, esta hipótese é rapidamente descartada tendo-se em vista o fato que a célula permanece fechada durante todo o tempo de medida.

Ainda com relação à reação entre $\mathrm{o}_{2} \mathrm{e} \mathrm{S}^{2-}$, realizou-se um experimento com geração de $\mathrm{I}_{2}$ in situ e a adição de volumes conhecidos de sulfeto, a fim de se verificar o efeito da inversão dos reagentes na reação. Foi preparada uma solução contendo $500 \mu \mathrm{L}$ de iodato $5,0.10^{-4} \mathrm{M}, 100 \mathrm{mg}$ de $\mathrm{Kl}$ e $1 \mathrm{~mL}$ de $\mathrm{H}_{2} \mathrm{SO}_{4} 9 \mathrm{M}$, encerrados em $20,00 \mathrm{~mL}$. A corrente inicial foi anotada e em seguida foram adicionados incrementos sucessivos de uma solução $10 \mathrm{ppm}$ de sulfeto. Os resultados estão na tabela 4 : 
TABELA 4: Resultados obtidos na adição de íons $\mathrm{S}^{2-}$ a uma solução de $\mathrm{I}_{2}$.

\begin{tabular}{|c|c|}
\hline Volume de $\mathrm{S}^{2-}, 10 \mathrm{ppm}(\mathrm{mL})$. & $i$ corrigido. (mA) \\
\hline $\mathbf{0 , 0 0}$ & $\mathbf{2 7 , 0}$ \\
\hline $\mathbf{0 , 4 3}$ & 19,7 \\
\hline $\mathbf{0 , 8 6}$ & 14,9 \\
\hline $\mathbf{1 , 2 9}$ & $\mathbf{8 , 9 0}$ \\
\hline 1,72 & $\mathbf{3 , 0 0}$ \\
\hline $\mathbf{2 , 1 5}$ & 1,00 \\
\hline
\end{tabular}

A curva obtida apresentou uma linearidade significativa, apontada pela regressão linear ( $r=0,9984)$ e o volume encontrado por extrapolação no eixo $x$ $(1,95 \mathrm{~mL})$ esteve muito próximo do volume teórico $(2,15 \mathrm{~mL})$. Foi verificado que o desaparecimento de $\mathrm{I}_{2}$ é proporcional ao sulfeto adicionado na célula voltamétrica. Dessa forma, pode-se considerar que a aplicação desta técnica para amostras reais implicaria em uma adaptação de um sistema que adicionasse volumes conhecidos da solução de sulfeto volátil a uma solução de $\mathrm{l}_{2} \mathrm{e}$ acompanhar a queda da corrente. No entanto algumas vantagens podem ser apontadas: não é necessário preparar curva padrão, basta padronizar a solução de sulfeto, que é um procedimento simples; as leituras de corrente no galvanômetro são suficieritemente estáveis e apesar de não se ter avaliado este parâmetro, Valente ${ }^{(140)}$ estimou que o limite de quantificação desta técnica foi de $500 \mathrm{ppb}$, suficientemente adequado para amostras de águas e de material particulado atmosférico.

\section{3. determinação de sulfeto volátil por polarografia de pulso diferencial}

Inicialmente, foi testado o método descrito por Fresenius et al. ${ }^{(146)}$, para a determinação de sulfeto em águas. Para isso, foi preparada uma solução contendo $24 \mathrm{~mL}$ de água deionizada e $1 \mathrm{~mL}$ de $\mathrm{NaOH} 2 \mathrm{M}$ e transferida para uma célula polarográfica. Adicionou-se em seguida um volume correspondente a 0,6 
ppm de íons $\mathrm{S}^{2-}$. Após 10 minutos de deaeração, iniciou-se a varredura no sentido catódico, com potencial inicial de $-0,2 \mathrm{~V}$. Obteve-se um pico em $-0,75 \mathrm{~V}$, com um valor de corrente de $200 \mathrm{nA}$.

Adicionou-se em seguida $2 \mathrm{~mL}$ de HOAc $2 \mathrm{M}$, e uma nova varredura foi realizada. Observou-se um novo valor de potencial, $-0,736 \mathrm{~V}$, cujo valor de corrente foi de $162 \mathrm{nA}$. As varreduras seguintes foram realizadas em intervalos de 3 minutos, obtendo-se valores de 162, 160, 160 e 160 nA para 3, 6, 9 e 12 minutos, respectivamente. Este resultado indica uma reprodutibilidade significativa dos valores de corrente . O polarograma obtido para esta solução está ilustrado na figura 6:

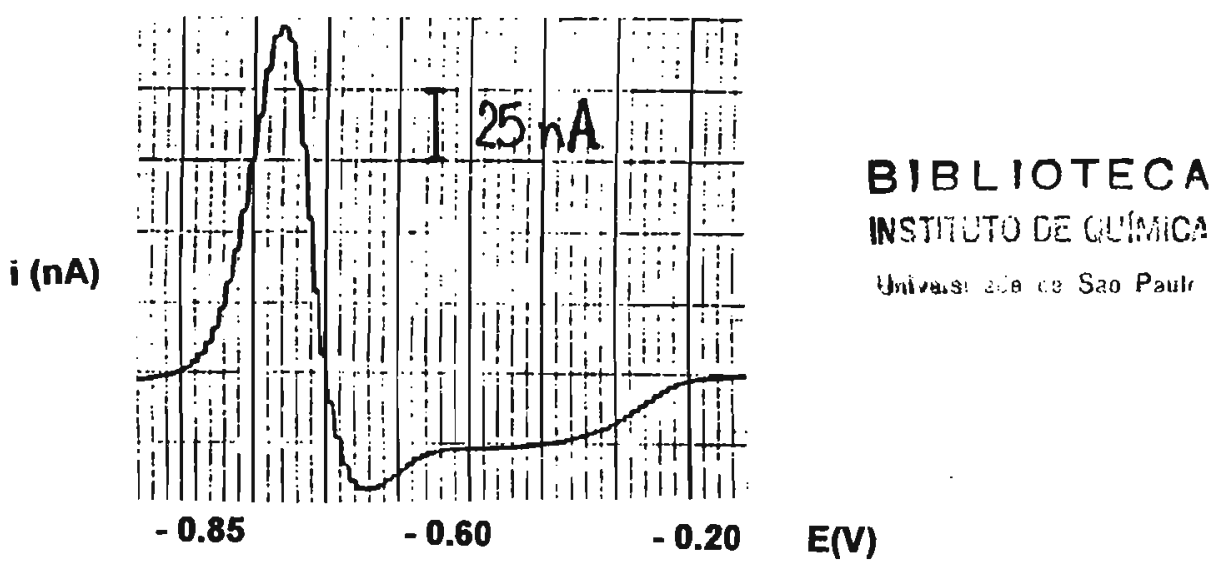

FIGURA 6 : Polarograma de uma solução contendo 0,6 ppm de ín sulfeto, em HOAc/NaOAc, $\mathrm{pH}<7$.

O pico observado nesta análise é sensivelmente deformado, provavelmente devido à formação do produto, HgS. Ao se tentar reproduzir este experimento, não se verificou uma repetibilidade satisfatória, o que sugeriu novas investigaçōes a respeito da formação de $\mathrm{HgS}$. Passou-se a testar o sistema gerador de AVS, e o produto recolhido analisado rapidamente por polarografia. Para isso, $10,00 \mathrm{~mL}$ de solução 0,85 ppm de sulfeto foram adicionados no tubo impinger e em seguida 10 $\mathrm{mL}$ de $\mathrm{HCl} 6 \mathrm{M}, 30$ minutos de arraste com $\mathrm{N}_{2}$ e o produto obtido recolhido em 
alguns mililitros de uma solução de $\mathrm{NaOH}, \mathrm{pH}$ 12. Em seguida, adicionou-se $1 \mathrm{~mL}$ de HOAc 2 M, e completou-se o volume com água deionizada. Montou-se novamente o sistema, recolhendo-se agora o volatilizado numa solução conhecida como SAOB ${ }^{(100)}$ (do inglês Sulfide Antioxidant Buffer), que é composta por $\mathrm{NaOH}(\mathrm{pH} 13)$, EDTA $0,2 \mathrm{M}$ e ácido ascórbico $0,2 \mathrm{M}$. Ao realizar a análise polarográfica destas duas soluçōes, não foram verificadas os picos polarográficos correspondentes à oxidação de $\mathrm{S}^{2-}$, como poderia se esperar nas condições experimentais adotadas.

A verificação do intervalo linear analítico foi realizada, a partir de soluções de 0,24 a 1,00 ppm de íons $S^{2-}$. A fiqura abaixo ilustra o polarograma obtido:

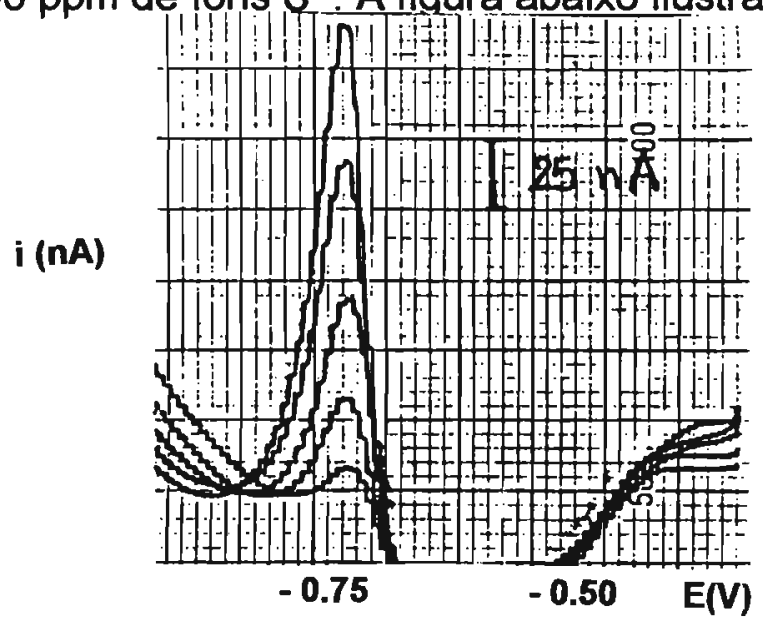

FIGURA 7 : Polarograma odııoo para aaçoes sucessıvas de sulfeto, no intervalo de 0,24 a 1,00 ppm.

As condições deste experimento foram : $\mathrm{pH} \approx 12, \mathrm{E}$ inicial de $-0,2 \mathrm{~V}$, tempo de gotejamento de 1s., velocidade de varredura de $5 \mathrm{mV} / \mathrm{s}$, sensibilidade $=1.10^{-9} \mathrm{~A} /$ $\mathrm{mm}$, pulsos de $50 \mathrm{mV}$. O potencial encontrado foi de $-0,65 \mathrm{~V}$ e a regressão linear resultou em : $\mathbf{i}=-4,47+0,082\left[\mathbf{S}^{2}\right](\mathbf{r}=0,9924)$. O limite de detecção foi estimado a partir da equação L.D. $=3 . \sigma / \alpha$, onde $\underline{\sigma}$ é a estimativa do desvio padrão $(\mathrm{N}=4)$, determinado a partir de medidas próximas a 1 nA e $\underline{\alpha}$ é o coeficiente angular da

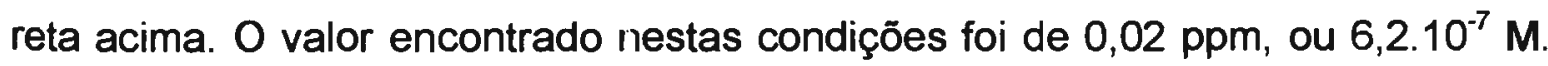
Este valor foi significativamente próximo do valor calculado por Turner et al. ${ }^{(145)}$, que foi de $3,5.10^{-7} \mathrm{M}$. 
Foi verificada ainda um novo intervalo analítico, com limites menores de concentração (de 0,04 a 0,95 ppm). Este experimento foi realizado em pH próximo de 7 , que mostrou-se ser mais favorável à analise polarográfica, diante dos problemas causados ao eletrodo em pHs alcalinos, principalmente em relação à oxidação do mercúrio. A tabela abaixo ilustra os valores obtidos para este experimento:

TABELA 5 : Resultados obtidos de linearidade de $\mathrm{S}^{2-}$, para o intervalo de 0,04 a $0,95 \mathrm{ppm}$

\begin{tabular}{|c|c|}
\hline $\mid \mathrm{S}^{2-} /, \mathrm{plm}$ & $i \eta(n \cdot 1)$ \\
\hline 0,04 & 7,5 \\
\hline 0,08 & 15,0 \\
\hline 0,16 & 53 \\
\hline 0,36 & 99 \\
\hline 0,75 & 124 \\
\hline 0,95 & 148 \\
\hline
\end{tabular}

As condições neste caso, foram: $\mathrm{pH} \approx 12, \mathrm{U}_{0}=-0,2 \mathrm{~V}$, tempo de gotejamento de $1 \mathrm{~s}$, velocidade de varredura de $5 \mathrm{mV} / \mathrm{s}$, sensibilidade de $2,5.10^{-9} \mathrm{~A} / \mathrm{mm}$, pulsos de $50 \mathrm{mV}$. O potencial encontrado foi diferente do experimento anterior $(-0,71 \mathrm{~V})$ e a regressão linear dos pontos resultou em : $\mathbf{i}=17,18+0,146\left[\mathbf{S}^{2}\right](\mathbf{r}=0,9542)$. Diante desses resultados, pode-se considerar que os desvios são acentuados quando se busca trabalhar em faixas de concentração próximas do limite de deteç̧ăo da técnica, estimado em 0,02 ppm.

Com a faixa linear estabelecida, foram testadas as condições de arraste de sulfeto volátil e sua imediata leitura no polarógrafo. Ao sistema de geração de SAV, foi adicionada uma quantidade exata de padrão de sulfeto, a fim de gerar na célula polarográfica $0,32 \mathrm{ppm}$. $\mathrm{O}$ sulfeto gerado foi recolhido em um pH próximo de 12 , que foi ajustado em 7 , com HOAc $50 \%$. A a análise polarográfica desta solução apresentou uma série de picos, e dentre esses, observou-se o de interesse em-0,70 V, cujo valor de corrente foi de 11nA. Duas extraçōes 
subsequentes foram realizadas, e os resultados foram de 12 e $11 \mathrm{nA}$, respectivamente. Conforme a equação $\mathbf{i}=-4,47+0,082\left[\mathrm{~S}^{2}\right]$, o valor de corrente esperado deveria ser mais alto, 25 nA. O método de adição padrão apresentou um valor de 0,15 ppm, idêntico ao valor encontrado acima.

Os resultados observados neste estudo nos levarn a considerar que existem fatores relacionados à formação da camada insolúvel do produto, $\mathrm{HgS}$ e que interferem significativamente nos resultados da polarografia. Segundo Turner et al. ${ }^{(145)}$, que realizaram um estudo minucioso sobre esta técnica na determinação de íons sulfeto e iodeto, quando o pulso de potencial é aplicado, sua aplicação se dá a um filme de $\mathrm{HgS}$ já formado e que a corrente nessa região é determinada preferencialmente pelas caracteristicas do filme do que pela taxa de difusão do material para a superfície do eletrodo. Desde que que as características do filme podem ser alteradas com o potencial aplicado e com a concentração, a corrente resultante pode não ser reprodutivel e porisso, esta técnica deve ser utilizada com extrema cautela. Recomendam ainda que deve-se utilizar tempos de gotejamento longos (3s) para se obter melhores resultados. Nos experimentos realizados, não se verificou melhorias significativas com essas novas condições.

Alguns trabalhos mencionam a aplicabilidade da polarografia para a determinação de SAV em amostras de sedimentos. ${ }^{(143,144)}$ No entanto, por causa dos possíveis problemas encontrados, muitos outros autores têm preferido a utilização de técnicas que nāo envolvam a formaçāo de filmes, como a espectrofotometria ou mesmo a potenciometria com eletrodo ion-seletivo.

Diante dos resultados encontrados através do estudo polarográfico para a determinação de SAV, tudo leva a crer que tanto a falta de repetibilidade, quanto os desvios observados de potencial devem estar associados à formação do filme de HgS. Talvez esta técnica seja mais apropriada para um reconhecimento

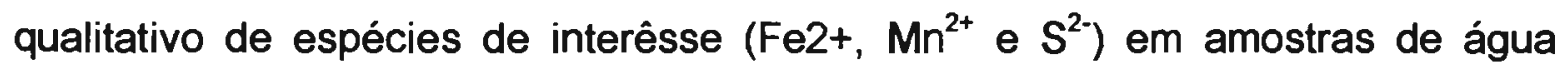
intersticial recém coletadas, como as de Davison et al ${ }^{(144)}$ Wallmann et al . ${ }^{(156)}$ 
realizaram determinações de sulfeto volátil em amostras de sedimentos, mas não apresentam um maior detalhamento dos procedimentos adotados e nem dos resultados obtidos.

Diante das observaçōes realizadas durante a possivel utilização da técnica polarográfica podemos inferir que esta técnica deve ser aplicada somente para fins qualitativos e consequentemente devemos procurar uma técnica que satisfaça as condiçōes exigidas para amostras reais. Nesse sentido, decidimos investigar a aplicação da potenciometria por eletrodo íon-seletivo para as amostras de sedimentos.

\section{4. determinação de sulfeto volátil por potenciometria com eletrodo íon- seletivo}

Inicialmente, foi verificada a faixa linear do eletrodo. A partir da soluçãomãe de ions $S^{2-}, 848$ ppm (ver item 2.4.2.), foram preparadas soluções em dois intervalos de concentração, a saber: 0,02 a 0,32 ppm e 0,20 a 2,00 ppm. Foram adicionados $5,0 \pm 0,2 \mathrm{~mL}$ de uma solução conhecida como $\mathrm{AAR}^{(100)}$ ( do inglês Anti-Oxidant Reagent ), que consiste de ácido ascórbico $(0,09 \mathrm{M})$, EDTA $(0,1 \mathrm{M})$ e $\mathrm{NaOH}(0,6 \mathrm{M})$, quantidade necessária de padrão e completou-se o volume para $25,00 \mathrm{~mL}$ com água deionizada. Os resultados encontrados na verificação da linearidade entre 0,02 e 0,32 ppm estão na tabela abaixo:

TABELA 6 : Resultados obtidos para o intervalo de 0,02 a 0,32 ppm de $\mathrm{S}^{2-}$

\begin{tabular}{|c|c|}
\hline$\left\langle\mathbf{S}^{2-} / \cdot p p m\right.$ & $\boldsymbol{E}(\boldsymbol{m} \boldsymbol{W})$ \\
\hline 0,02 & $-559,8$ \\
\hline 0,04 & $-620,3$ \\
\hline 0,08 & $-639,7$ \\
\hline 0,16 & $-650,7$ \\
\hline 0,32 & $-661,2$ \\
\hline
\end{tabular}


A figura 8 ilustra os resultados acima:

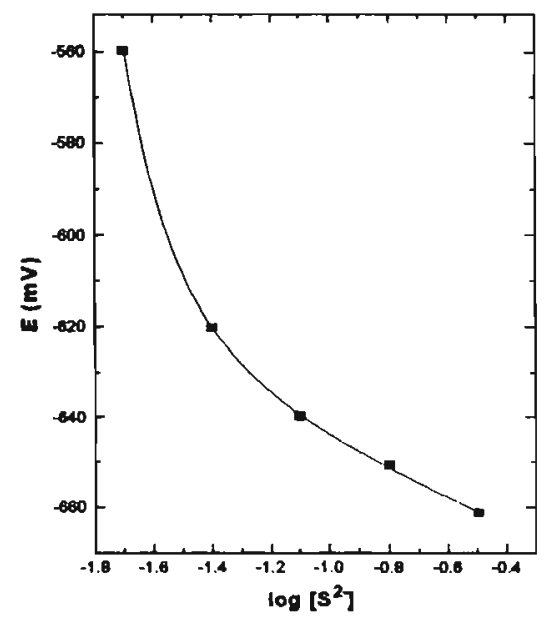

FIGURA 8 : Verificação da linearidade do eletrodo no intervalo de 0,02 a 0,32 ppm de $S^{2-}$.

A curva acima apresenta uma furma arredondada, típica dos eletrodos íonseletivos ${ }^{(156)}$. Neste estudo, foi verificado 0 arredondamento para as concentrações mais baixas de sulfeto $(0,02,0,04$ e 0,08 ppm, respectivamente). Considerando-se estes pontos na regressão linear, verifica-se um coeficiente de correlação linear de $-0,9181$, que demonstra a falta de linearidade do eletrodo neste intervalo. No entanto, se forem excluidos os dois primeiros pontos $(0,02 \mathrm{e}$ 0,04 ), pode-se observar que o cceficiente de correlação linear assume o valor de $-0,9987$, indicando assim uma linearidade no segundo intervalo, de 0,08 a 0,32 ppm. Desta forma, considerou-se neste estudo o valor de 0,08 ppm como sendo ○ limite de determinação inferior, ou limite de quantificação para o método proposto. 
A figura abaixo ilustra a verificação da linearidade do eletrodo para outra faixa de concentração, 0,20 a 2,00 ppm.

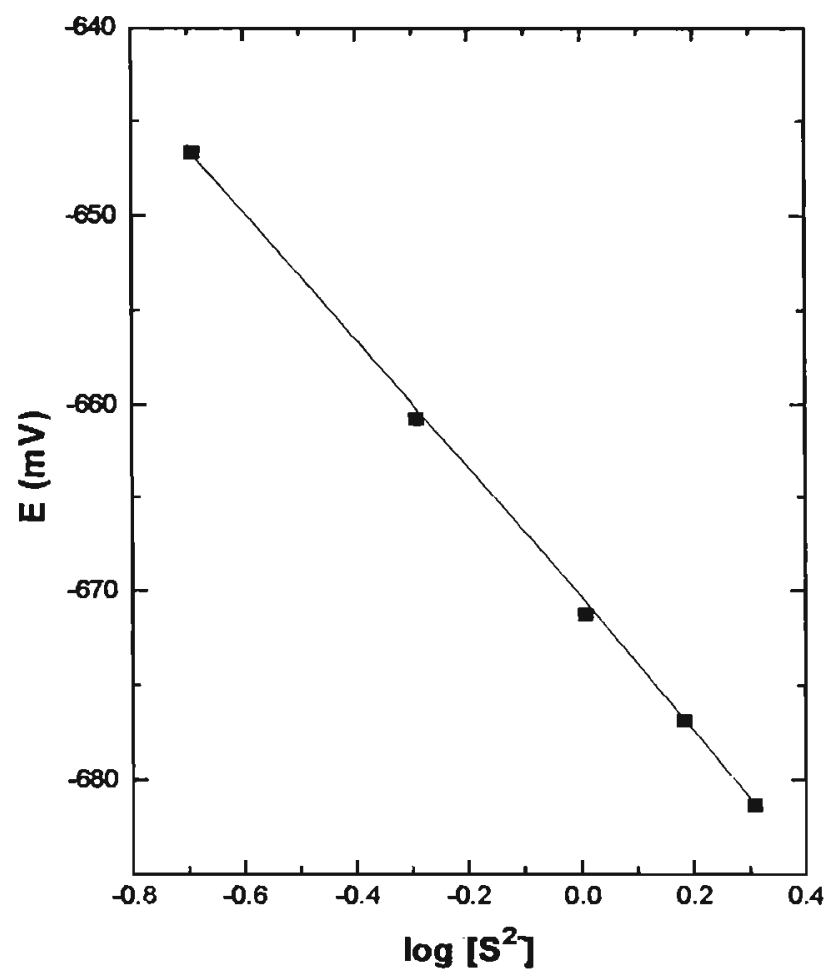

FIGURA 9: Verificação da linearidade do eletrodo no intervalo de 0,20a 2,00 ppm de sulfeto, em meio de AAR.

Já neste intervalo verifica-se que o eletrodo responde linearmente $(r=-0,9999)$ à concentração de sulfeto. Através de inúmeras leituras, foi verificado que acima de 2,00 ppm, há uma espécie de patamar de potencial, sugerindo assim uma condição de saturação da membrana de $\mathrm{Ag}_{2} \mathrm{~S}$. Portanto, a faixa analítica de trabalho estabelecida neste estudo foi de 0,08 a 2,00 ppm.

A fim de se estabelecer o método mais adequado para o cálculo de concentração de sulfeto, foram testados o método de adição de padrão e o método de curva de calibração. 
Como o próprio nome já diz, o método de adição de padrão se dá a partir de adições sucessivas de padrões de $\mathrm{S}^{2-}$ em uma amostra com concentração desconhecida deste íon. Esta concentraçào pode ser encontrada a partir do gráfico de $10^{\mathrm{ES}}$ versus concentração de $\mathrm{S}^{2-}$, onde $\mathrm{E}$ é o potencial e $\mathrm{S}$ é a inclinação, obtida a partir de uma curva com padrões da espécie de interesse ${ }^{(157)}$. A tabeía abaixo ilustra os resultados obtidos de um estudo realizado com um padrão de sulfeto com concentração de 0,32 ppm :

TABELA 7: Verificação dos resultados obtidos com o método de adição de padrão para um padrão de sulfeto $(0,32 \mathrm{ppm})$, em quatro dias diferentes:

\begin{tabular}{|c|c|c|c|c|}
\hline 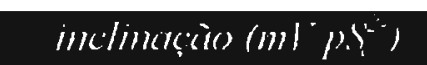 & 27.14 & 36.45 & 38.26 & 35,75 \\
\hline$\left[S^{2^{2}}\right] \mathrm{ppm}$, (4 adiçōes) & 0,23 & 0,49 & 0,53 & 0,47 \\
\hline$\left[S^{2-}\right] \mathrm{ppm},(2$ adições $)$ & 0,18 & 0,37 & 0,41 & 0,35 \\
\hline
\end{tabular}

Através da tabela acima, pode-se verificar que a cada determinação realizada, um valor diferente de inclinação foi obtido. Isto se deve ao fato de que embora haja uma dependência da inclinação da curva (S) com a temperatura, acima desta influência ocorre a modificaçāo desta matriz pelas adições sucessivas de sulfeto, o que nos parece o principal efeito nas diferenças de concentrações de sulfeto, ao realizar-se duas ou quatro adições. No entanto, tais variações de inclinação são esperadas e não constituem problemas às determinações.

Um aspecto importante a ser abordado é o número de adições padrão que deve ser considerado nas análises. Pode-se observar que os valores obtidos para 4 adições de padrão são sempre maiores que os valores obtidos para duas 2 adições. Tal fenômeno se deve, provavelmente, a efeitos de variação de força iônica no meio e/ou mudanças da estrutura da matriz, insuficientemente controlada pela solução de ajuste (SAOB). Os resultados de sulfeto mostrados acima em 2 adições de padrão foram sempre menores que os resultados obtidos com 4 adições. 
A média dos resultados encontrados para 4 adições de padrão foi de $0,43 \pm$ 0,14 ppm e a média dos valores resultantes de duas adiçōes foi de $0,33 \pm 0,10$ ppm.

Verificou-se que as estimativas dos desvios-padrão foram significativamente elevadas, mesmo para o método com duas adições, podendo assim trazer problemas à determinação desta espécie nas amostras reais. Além disso, nenhuma vantagem foi constatada no uso deste método, pois há a necessidade de se preparar uma curva diariamente para se estimar a inclinação, sendo preferível assim utilizar-se o método de curva de calibração. Este método mostrou -se extremamente satisfatório no tocante à garantia dos resultados obtidos até então.

\section{5. determinações com o sistema "gerador" de SAV}

A fim de se verificar a recuperação do sistema proposto (item 2.4.2), foi utilizada uma solução padrão de sulfeto cujo volume tomado $(10,00 \mathrm{~mL})$ representou exatamente $0,085 \mathrm{mg}$ desta espécie. Este estudo serviu também para estabelecer o tempo mais favorável de extração. Os resultados encontrados foram: $15 \mathrm{~min} ., 0,088 \mathrm{mg} \mathrm{(105 \% );} 30 \mathrm{~min}$., 0,085 mg (100\%); $45 \mathrm{~min}, 0,081 \mathrm{mg}$ (95\%). A recuperação proposta por ASTM-APHA ${ }^{(57)}$ para sulfeto em águas é de $80 \%$ a $120 \%$, com uma precisão de $10 \%$ (alto nível) para duplicatas. Dessa forma, verifica-se que a recuperação de $\mathrm{S}^{2-}$ é virtualmente atingida no sistema proposto.

Não há um consenso com relação ao ternpo de arraste de SAV para amostras de sedimentos. Alguns autores recomendam um tempo de 15 minutos $^{(102,104)}$, outros 30 minutos $^{(158)}$ e existem aqueles que recomendam 60 minutos. ${ }^{(84)}$ Portanto, deve-se buscar o tempo mais adequado de arraste a partir de um procedimento de análise. Nos experimentos realizados, embora se tenha 
atingido a recuperação total no tempo de 15 minutos, o tempo adotado para as amostras reais foi de 30 minutos, suficiente para garantir que a extração se complete totalmente no tempo previsto.

Após ter-se verificado o bom funcionamento do sistema de arraste de SAV, realizou-se um teste com soluções absorvedoras. Foram testadas soluções de $\mathrm{Zn}(\mathrm{OAC})_{2}$ em diferentes condições, a fim de se verificar a eficiência desta solução na etapa de extração de AVS. Os resultados estão na tabela abaixo:

TABELA 8: Estudo de recuperação de sulfeto em solução de $\mathrm{Zn}(\mathrm{OAC})_{2} 5 \%$.

\begin{tabular}{|c|c|c|c|}
\hline solluçâno/meio ") & $Z n(() \cdot 4 c)_{2}+N a() A_{c}$ & $Z n(O A C)=$ & $\operatorname{Zn}(0) \cdot 4 c)=+\mathrm{NaF}(\mathrm{Cl})$ \\
\hline$\overline{p H}$ & 6,8 & 6,7 & 6,6 \\
\hline recuperação (\%) & 96 & 71 & 102 \\
\hline
\end{tabular}

*as concentraçates de $\mathrm{NaOAc}_{\mathrm{NaHCO}}$ foram de $0,010 \mathrm{M}$

Através dos resultados de recuperação apresentados acima, pode-se observar que juntamente com o arraste de SAV, foi arrastada uma certa quantidade de $\mathrm{HCl}(6 \mathrm{M})$, que não interfere no equilibrio da reação de formação de $\mathrm{ZnS}$ quando o meio está levemente a!calino ( $\mathrm{NaOAc}$ ) ou tamponado $\left(\mathrm{NaHCO}_{3}\right)$. Portanto, desde que a solução seja preservada da ação do ácido durante a etapa de arraste, ela poderia ser utilizada como uma opção na determinação de sulfeto. No entanto, ao se utilizar esta solução nas leituras de $\mathrm{S}^{2-}$ por eletrodo ínseletivo, foi verificado que a presença de ions $\mathrm{Zn}^{2+}$ causa uma sensivel, porém representativa, variação (positiva) nas leituras do eletrodo de $\mathrm{Ag}_{2} \mathrm{~S}$, levando-se assim a optar pela solução AAR como sendo a mais apropriada para a determinação de SAV.

A recuperação em amost as reais foi a última etapa cumprida a fim de estabelecer esta metodologia para amostras de sedimentos. Este experimento foi conduzido utilizando-se uma amostra de sedimento que apresentou os niveis mais baixos de SAV , 3,5 ppm (correspondente à amostra de jusante de Barra Bonita, que será apresentada a seguir). Adicionou-se à esta amostra uma quantidade de padrão de $\mathrm{S}^{2-}$, a fim de se ter como concentração total $20 \mathrm{ppm}$. Os 
resultados encontrados neste estudo de recuperação foram de 19,2 ppm e 21,5 ppm; $96 \%$ e 107,5\%, respectivamente. Portanto, dentro dos critérios de aceitação de resultados do ASTM-APHA ${ }^{(57)}$, pode-se considerar que a recuperação é satisfatoriamente verificada também para as amostras reais, com bom rendimento.

\section{6. determinação de SAV em amostras do Tieté}

A partir do estabelecimento do método analítico para sulfetos ácidos voláteis, passou-se à determinação das amostras de sedimento do rio Tietê. As pesagens das amostras foram realizadas em atmosfera de $N_{2}$, com a balança analitica disposta no interior de um glove-tag (atmosbag $\circledast$, Aldrich), a fim de se evitar a oxidação do ar. Um ciclo de 3 enchimentos, seguidos de 3 esvaziamentos completos foi adotado, garantindo-se assim uma atmosfera controlada de $\mathrm{N}_{2}$. Ao se abrir o frasco de amostra, 3 sub-amostras com cerca de $5 \mathrm{~g}$ foram retiradas para se estimar a massa seca. A outra porção, de 50 a $500 \mathrm{mg}$ de amostra, foi introduzida in natura no interior de um tubo impinger, previamente tarado. Este tubo foi conduzido para o sistema de arraste de SAV e as outras sub -amostras foram mantidas em uma estufa a $55^{\circ} \mathrm{C}$, por $96 \mathrm{hs}$. Os resultados de SAV estão na tabela abaixo:

TABELA 9: Resultados de SAV obtidos para algumas amostras escolhidas do Rio Tietê:

\begin{tabular}{|c|c|}
\hline ponto amostral & $\begin{array}{l}\text { Sulfeto Ácillo } \\
\text { Volútil( } \mu \text { mol/g) }\end{array}$ \\
\hline Casa do Luis (Pirapora do Bom Jesus) & $450 \pm 2,5$ \\
\hline Reservatório de Rasgão (Pirapora) & $19,7 \pm 0,4$ \\
\hline Tecelagem (Pirapora) & $19,1 \pm 0,5$ \\
\hline Ponte rio Tietê - Capivari & $4,12 \pm 0,25$ \\
\hline Entrada de Barra Bonita & $3,22 \pm 0,28$ \\
\hline Jusante de Barra Bonita & $\mathbf{0 , 1 1} \pm \mathbf{0 , 0 2}$ \\
\hline Ilha de Barra Bonita & $<\mathbf{L} . \mathbf{Q}^{\star \star \star}$ \\
\hline
\end{tabular}

* resultados de triplicatas de determinações

** o resultado do limite de quantificação foi estimado em 0,03 ppm. 
O critério de escolha de amostras para a determinação de SAV foi estudado a fim de se ter uma idéia da distribuição de sulfetos voláteis ao longo do trecho de estudo. Foram escolhidos 3 pontos amostrais na região de Pirapora, uma ponto amostral a cerca de $70 \mathrm{~km}$ desta região (ponte rio Tietê-Capivari) e 3 pontos amostrais no reservatório de Barra Bonita. Deve-se frisar que, apesar dos sulfetos voláteis serem muito reativos com o oxigênio do ar, os cuidados apontados no item 3.1., que tratam da qualidade de preservação das amostras do Tietê, garantem a validade dessas análises, pois variações nos niveis de SAV seriam rapidamente detectados através das alterações dos valores de $E_{H}$, superiores a $50 \mathrm{mV}$, que não foram verificados neste estudo.

Os resultados apresentados na tabela acima indicam uma elevada concentração de sulfetos voláteis presentes nas amostras do Tietê. Para se ter uma idéia de tais riveis, basta dizer que nos mangues, ambientes naturalmente redutores, os valores máximos de SAV encontrados são cerca de $310 \mu \mathrm{mol} / \mathrm{g}$. ${ }^{(102)}$ A amostra de Casa do Luis (Pirapora), apresentou $450 \pm 2,5 \mu \mathrm{mol} / \mathrm{g}$. Esse valor está fortemente correlacionado à significativa carga poluidora, que se concentra principalmente no reservatório de Pirapora do Bom Jesus. Em ambientes como o de Pirapora, com elevado nivel de estagnação e anaerobiose, a principal rota de formação de sulfetos vem de mediação bacteriana. Isto se dá pela ação da bactéria Desulfovibrio, que atua na redução química de íons sulfato a íons sulfeto em meio anaeróbico, segundo a reação ${ }^{(19)}$.

$$
\mathrm{SO}_{4}{ }^{2-}+2\left\{\mathrm{CH}_{2} \mathrm{O}\right\}+2 \mathrm{H}^{+} \rightarrow \mathrm{H}_{2} \mathrm{~S}(\mathrm{~g})+2 \mathrm{CO}_{2}(\mathrm{~g})+2 \mathrm{H}_{2} \mathrm{O}(\log \mathrm{K}=37,6) \quad \text { eq.3.1, }
$$

onde $\left\{\mathrm{CH}_{2} \mathrm{O}\right\}$ representa a matéria orgânica não refratária e o íon $\mathrm{SO}_{4}{ }^{2-}$ é o oxidante, ou seja, aceptor de elétrons.

Este mecanismo deve ser predominante em todo o trecho que apresenta baixos niveis de $\mathrm{O}_{2}$.

Após o ponto amostral de casa do Luís, verifica-se que os níveis de sulfeto 
volátil caem cerca de 20 vezes (19,62 $\mu \mathrm{mol} / \mathrm{g}$ em Rasgão e 19,07 $\mu \mathrm{mol} / \mathrm{g}$ em Tecelagem, respectivamente), em decorrência do efeito da barragem de Pirapora, que propicia uma difusão forçada de $\mathrm{O}_{2} \mathrm{e}$, consequentemente, a oxidação dos sulfetos, atingindo parte da camada anóxida dos sedimentos de fundo (constituído essencialmente de sulfeto de ferro amorfo e matéria orgânica muito fina).

Após o reservatório de Tecelagem, verifica-se que os níveis de SAV caem 6 vezes em relação este ponto $(4,12 \mu \mathrm{mol} / \mathrm{g}$ nas amostras referentes a Ponte do rio Tietê-Capivari e 3,22 $\mu \mathrm{mol} / \mathrm{g}$ referente a amostra de entrada de Barra Bonita. Isto se deve principalmente à distância que apresentam da região de Pirapora e por receberem uma carga poluidora muito menor quando comparada com a da cidade de São Paulo. Convém lembrar ainda que neste trecho do Tietê, predomina o regime pertinente a um rio de planicie de inundação, que propicia uma melhoria da qualidade da água e consequentemente do sedimento de fundo. A concentração de sulfetos voláteis está intimamente relacionada com o regime sedimentário do corpo d'água, e também às ciclagens óxidas / anóxidas naturais. Sendo o sulfeto uma espécie muito instável sob o ponto de vista redox, é certo encontrar-se valores mais baixos em ambientes que apresentem efeitos de escoamento de fundo, como é o caso do Tietê, nos trechos à jusante do reservatório de Tecelagem.

Os resultados encontrados em Barra Bonita são coerentes com a sua situação ambiental, pois o resultado da amostra referente a jusante de Barra Bonita $(0,11 \mu \mathrm{mol} / \mathrm{g})$ reflete 0 efeito da oxigenação da água à jusante do reservatório. O ponto amostral referente a margem esquerda-itha de Barra Bonita apresenta uma condição óxida $\left(E_{H}=+170 \mathrm{mV}\right)$ e consequentemente não deve apresentar valores para SAV, confirmado em nosso laboratório

Segundo a classificação geoquímica de Berner para ambientes sedimentários, são chamados anóxidos e sulfídricos aqueles que apresentam concentrações de $\mathrm{O}_{2}$ menores que $10^{-6} \mathrm{M}$ e de $\mathrm{H}_{2} \mathrm{~S}$ iquais ou superiores a $\underline{10^{-6}} \underline{\mathrm{M}}$, além de fases geoquímicas características, tais como pirita $\left(\mathrm{FeS}_{2}\right)$, 
marcassita $\left(\mathrm{FeS}_{2}\right)$, rodocrosita $\left(\mathrm{MnCO}_{3}\right)$, alabandita $(\mathrm{MnS})$ e matéria orgânica ${ }^{(159)}$. Baseando-se nos resultados de SAV encontrados no presente estudo, essa situação foi verificada desde Pirapora até a entrada de Barra Bonita, caracterizando assim este trecho do rio como sendo anóxido e predominantemente sulfídrico. A amostra correspondente à jusante de Barra Bonita $\left(3,5 \mathrm{ppm}\right.$ ou $1,1.10^{-7} \mathrm{M}$ de $\mathrm{H}_{2} \mathrm{~S}$ ) pertence, segundo Berner à classificação não sulfídrica $\left(\mathrm{H}_{2} \mathrm{~S}<10^{-6} \mathrm{M}\right)$ e pós-óxida, não devendo apresentar, segundo o autor, minerais de sulfeto, além de pouca matéria orgânica. Veremos posteriormente que é verificado para esta amostra realmente um baixo teor de matéria orgânica.

Com relação à reatividade do SAV presente nos sedimentos, DiToro et al. ${ }^{\text {(84) }}$ consideram que o sulfeto de ferro amorfo é a forma predominante de sulfetos presente e que quando um metal (que forma sulfeto mais insolúvel que o de ferro) é adicionado ao meio, ele forma rapidamente o sulfeto correspondente por deslocamento do ion $\mathrm{Fe}^{2+}$. Isto explica, segundo os autores, a formação dos sulfetos dos metais em meio heterogêneo. Algumas considerações também devem ser com relação às espécies de enxofre presentes nos sedimentos. A redução via bacteriana de sulfatos, passando por enxofre elementar infere a formação de ín polissulfeto, que pode explicar a reversibilidade das medidas de $E_{H}$, como mostrado no item 3.6.1.Schwarzenbach e Fischer ${ }^{(160)}$, dentre outros autores ${ }^{(161-164)}$, sugerem a formação do ion polisulfeto $\left(S_{n}{ }^{2-}\right)$ em águas, através da reação de enxofre elementar (S) com o íon hidrogenosulfeto $\left(\mathrm{HS}^{-}\right)$e/ou $\mathrm{S}^{2-}$. Se a concentração de $\mathrm{HS}^{-}$for mantida constante e variar-se a concentração de $\mathrm{S}$, uma série de espécies de polissulfetos, podem ser formadas, como segue:

$$
\begin{array}{ll}
\mathrm{HS}^{-}+(1 / 8) \mathrm{S}_{8} \rightarrow \mathrm{S}_{2}{ }^{2-}+\mathrm{H}^{+} & \text {eq } 3.2 \\
\mathrm{HS}^{-}+(1 / 4) \mathrm{S}_{8} \rightarrow \mathrm{S}_{3}{ }^{2-}+\mathrm{H}^{+} & \text {eq.3.3 } \\
\mathrm{HS}^{-}+(3 / 8) \mathrm{S}_{8} \rightarrow \mathrm{S}^{2-}+\mathrm{H}^{+} & \text {eq.3.4 } \\
\mathrm{HS}^{-}+(1 / 2) \mathrm{S}_{8} \rightarrow \mathrm{S}^{2-}+\mathrm{H}^{+} & \text {eq.3.5 } \\
\mathrm{HS}^{-}+(5 / 8) \mathrm{S}_{8} \rightarrow \mathrm{S}_{6}{ }^{2-}+\mathrm{H}^{+} & \text {eq.3.6 }
\end{array}
$$


As espécies $\mathrm{S}_{\mathrm{n}}{ }^{2-}$ podem reagir com íons $\mathrm{H}^{+}$, em $\mathrm{pH}$ levemente ácido, para formar íons $\mathrm{HS}_{n}{ }^{-}$. La Mer e Kenyon ${ }^{(165)}$ há cerca de 50 anos atrás, consideraram que a partir do valor de saturação de enxofre elementar em água $\left(5.10^{-6} \mathrm{M}\right)$, podem ser atingidas as concentrações de equilíbrio de todos as espécies de polisulfetos. $A$ concentração de sulfetos voláteis em Pirapora é de $4,5.10^{-4} \mathrm{M}$ e portanto suficientemente elevada para formar os íons $S_{n}{ }^{2-}$, desde que haja uma concentração suficiente de enxofre elementar. Um dos mecanismos plausíveis de formação dessa espécie se dá quando ocorre a oxidação de $S^{2-}$ a $S^{0}$, p.e., com a participação de íons $\mathrm{Fe}^{3+}$, que oxidam $0 \mathrm{H}_{2} \mathrm{~S}$ dissolvido e liberam 2 prótons, segundo a reação:

$$
\mathrm{Fe}^{3+}+\mathrm{H}_{2} \mathrm{~S} \rightarrow \mathrm{Fe}^{2+}+\mathrm{S}^{0}+2 \mathrm{H}^{+}
$$

o outro mecanismo se dá por um reação autocatalítica, mas ainda há poucas evidências desta hipótese.

Segundo O"Neill ${ }^{(154)}$, em ambientes onde há uma concentração significativa de $\mathrm{H}_{2} \mathrm{~S}$, verifica-se tanto a formação de troilita quanto a de pirita, segundo as reações:

$$
\begin{aligned}
& 2 \mathrm{Fe}(\mathrm{OH})_{3}+3 \mathrm{H}_{2} \mathrm{~S} \rightarrow 2 \mathrm{FeS}+\mathrm{S}^{0}+6 \mathrm{H}_{2} \mathrm{O} \text { eq. } 3.8 \\
& \mathrm{FeS}+\mathrm{S}^{0} \rightarrow \mathrm{FeS}_{2} \\
& \text { eq. } 3.9
\end{aligned}
$$

Como já mencionado anteriormente, durante a redução bacteriana de sulfatos, parte do enxofre nascente pode reagir com os íons sulfetos formados.

A presença de polissulfetos nos sedimentos é de fundamental importância a respeito da disponibilidade biológica dos metais pesados. Este assunto será abordado adiante. 


\subsection{1. relações entre $E_{H}$ e pS nas amostras de sedimentos do Tietê}

Uma maneira de se investigar a presença de polissulfetos nos sedimentos, é através da relação entre o potencial redox $\left(E_{H}\right)$ e pS $\left(-\log \left[S^{2-}\right]\right)$. Peschanski f: Valensi $i^{(166)}$ apresentaram uma importante contribuição aos estudos eletroquímicos das soluções aquosas de polissulfetos. Não menos importantes foram os excelentes estudos de Berner $^{(68)}$, realizando medidas eletroquímicas de polissulfetos em amostras de sedimentos e culturas celulares. Os resultados encontrados neste estudo serão apresentados abaixo (Tabela 10). Consideremcs as medidas de $E_{H}$ da tabela 2 e os correspondentes valores de sulfeto ácido volátil, da tabela 9 , para as amostras do Tietê:

TABELA 10: Resultados de potenciais redox $\left(E_{H}\right)$ e correspondentes valores de pS

\begin{tabular}{|c|c|c|}
\hline amostru & $\left(E_{I I}\right), m I^{r}$ & $\log \left|S^{2-}\right|^{\circ}$ \\
\hline Casa Luis-Pirapora & -290 & 4,16 \\
\hline Rasgãa-Pirapora & -206 & 2,80 \\
\hline Tecelagem-Pirapora & -199 & 2,78 \\
\hline ponte do rio Tietê-Capivari & -152 & 2,12 \\
\hline entrada de Barra Bonita & -190 & 2,02 \\
\hline Jusante de. Barra. Bonita & -220 & $\mathbf{0 , 5 4}$ \\
\hline
\end{tabular}

Se forem lançados em gráfico os valores de $E_{H}$ com seus correspondentes valores de pS, para os 4 primeiros pontos (Casa do Luis, Rasgão, Tecelagem e Ponte do rio Tietê-Capivari, respectivamente), verifica-se que há uma correlação significativa ( $r=0,9979$ ) entre esses valores. Isto revela algo inédito em nossos estudos, pois o eletrodo de platina responde linearmente à presença de $S^{2-}$ para 
as concentrações mais elevadas desta espécie. Considerando-se que o par $\mathrm{S}^{2-} / \mathrm{S}^{0}$ é irreversível e que os valores de $E_{H}$ mostraram medidas de um sistema reversivel, infere-se a presença de ín polissulfeto, que forma um sistema reversível $\mathrm{S}_{\mathrm{n}}{ }^{2} / \mathrm{S}^{0}$. Assim, o $\mathrm{H}_{2} \mathrm{~S}$ recolhido quando das medidas de AVS, seria oriundo da decomposição de íon polissulfeto em meio ácido. O potencial da célula é dado portanto, pelo par redox das espécies complexas de polissulfetos e enxofre elementar $\left(S_{n}{ }^{2-} / S^{0}\right)$. A dependência de $E_{H}$ com pS deixa de ser linear quando são considerados os resultados de Barra Bonita: Ao incluir-se os pontos correspondentes ao reservatório de Barra Bonita, verifica-se uma correlação de $E_{H}$ com pS de $r=0,5168$. Os valores encontrados para as amostras de entrada de Barra Bonita ( $E_{H}=-190 \mathrm{mV}$ e SAV $=104 \mathrm{ppm}$ ) mostram que para o valor de $E_{H}$ observado, o SAV é muito baixo, o que sugere outras espécies redutoras presentes na amostra que justificam o potencial medido. $O$ mesmo fato se observa para a amostra de jusante de Barra Bonita ( $E_{H}=-220 \mathrm{mV}$ e SAV $=3,5 \mathrm{ppm}$ ). A causa destes desvios deve estar associada a possiveis lançamentos de efluentes da indústria de álcool e açúcar (Usina da Barra) que se localiza na região de Barra Bonita e tem sido citada como fonte puntual de contaminação deste reservatório ${ }^{(137)}$.

Os resultados observados para as amostras de casa do Luis (Pirapora) até ponte do rio Tietê-Capivari (que representam consequentemente o trecho de interesse), indicam que o $E_{H}$ é controlado pela concentração de sulfeto volátil presente, que provém do polissulfeto original. Mais do que isso, confirma-se a hipótese lançada acima, de que há uma quantidade significativa de polissulfetos presentes, devido às medidas reversíveis de $E_{H}$ e de reações com $\mathrm{HCl} 6 \mathrm{M}$, obtendo-se em ausência de ar, de imediato, significativa quantidade de $\mathrm{S}$ e de $\mathrm{H}_{2} \mathrm{~S}$.

Outro ponto a ser enfatizado é que os resultados obtidos neste estudo corroboram com as classificações geoquímicas sugeridas por Berner ${ }^{(159)}$, conclusivas de que o ambiente de Pirapora era anóxido e sulfídrico (ver item 3.6.). 
Através da relação entre $E_{H}$ e $p S$, pode-se considerar que não somente casa do Luis, mas todo o trecho entre Pirapora e entrada de Barra Bonita apresenta as características definidas por Berner. Tais consideraçōes podem ser provadas por simples medidas de $E_{H}$ e de SAV, como as realizadas neste trabalho.

Com relação às espécies de enxofre presentes numa amostra de sedimento, Voge ${ }^{(167)}$ encontrou trocas muito rápidas entre $\mathrm{S}^{35}$ elementar radioativo e sulfeto de amônio não radiativo, sugerindo-se assim reversibilidade para o par redox $S^{2-} / S^{0}$. Pechanski e Valensi ${ }^{(16)}$ dissolveram enxofre elementar em uma soluçāo aquosa de $\mathrm{Na}_{2} \mathrm{~S}$ e vorificaram que além do sistema $\mathrm{S}_{n}{ }^{2} / S^{0}$ ser reversivel em uma célula eletroquímica, foi possivel constatar que, na realidade, cada semicélula intermediária de $\mathrm{S}_{n}{ }^{2-}$ a $\mathrm{S}_{n}{ }^{5}$ é também termodinamicamente reversivel. Nos estudos realizados com as amostras do Tietê, foi possivel em algumas subamostras verificar-se a presença de $\mathrm{S}^{0}$ através de testes com $\mathrm{HCl}$. Tal presença justifica os valores correlacionados de $E_{H}$ e de $p S$, e não o par $S^{2} / S^{0}$, conforme sugerem os referidos autores ${ }^{(167)}$. Isto pode ser verificado com os valores das amostras próximas a Barra Bonita, quə apresentam valores representativos de SAV, mas não correlacionados com c $E_{H}$ lido, por causa da menor concentração de polissulfetos presente nessas amostras. Este fato corrobora com a hipótese levantada acima, do eletrodo de platina estar respondendo unica e tão somente ao par $S_{n}{ }^{2-} / S^{0}$, termodinamicamente reversivel, e não ao par $S^{2-} / S^{0}$, termodinamicamente irreversivel.

Os resultados de SAV, além de possibilitarem classificar ambientes sedimentários como os do Tietê propiciam esclarecer o tipo de interação dos metais pesados nos sedimentos. A determinação dos metais totais, seu potencial biodisponivel à biota e sua distribuição nas fases geoquímicas serão abordados a seguir. 
3.7. determinação de metais pesados por espectrofotometria de absorção atômica.

Serão explanados a seguir, os resultados referentes às determinações de metais totais, aos metais biodisponiveis e à distribuição dos metais nas diversas fases que compõem o sedimento

\subsection{1. determinação de metais totais nos sedimentos}

Os resultados de aberturas totais de amostras de sedimentos indicam os niveis totais dos metais presentes (também chamados de "strongly bound", fortemente ligados) e dão uma boa idéia do nivel de estocagem dessas espécies nos sedimentos. Foram escolhidas para este estudo duas amostras: casa do Luis (Pirapora do Bom Jesus) e entrada de Barra Bonita. A escolha destas duas amostras foi baseada nos estudos de Eysink et al ${ }^{(26)}$, que sugerem uma dinâmica intensa de transferência de espécies quimicas proveniente de Pirapora até Barra Bonita. A amostra de casa do Luís (Pirapora) apresenta, segundo esses autores, elevados níveis de metais pesados, muito acima dos niveis naturais, além dos níveis de SAV já apresentados. A amostra referente a entrada de Barra Bonita também apresenta, segundo as consideraçōes desses autores, suspeitas de contaminação por metais. Nas aberturas de amostras realizadas por microondas, a programação de aquecimento seguiu os seguintes passos ${ }^{(10.168)}$ :

TABELA 11: Programação dos estágios de operação do equipamento de microondas.

\begin{tabular}{|c|c|c|c|c|c|}
\hline \multirow[t]{2}{*}{ Condiçrẽex } & \multicolumn{5}{|c|}{ estágio } \\
\hline & 1 & 2 & 3 & 4 & 5 \\
\hline potência (W) & 520 & 0 & 520 & 0 & 520 \\
\hline pressão (psi) & 40 & 0 & 80 & 0 & 120 \\
\hline tempo (min.) & 3 & 5 & 3 & 5 & 3 \\
\hline
\end{tabular}


O gráfico que representa o comportamento da amostra durante o ataque por microondas está representado na figura 12:

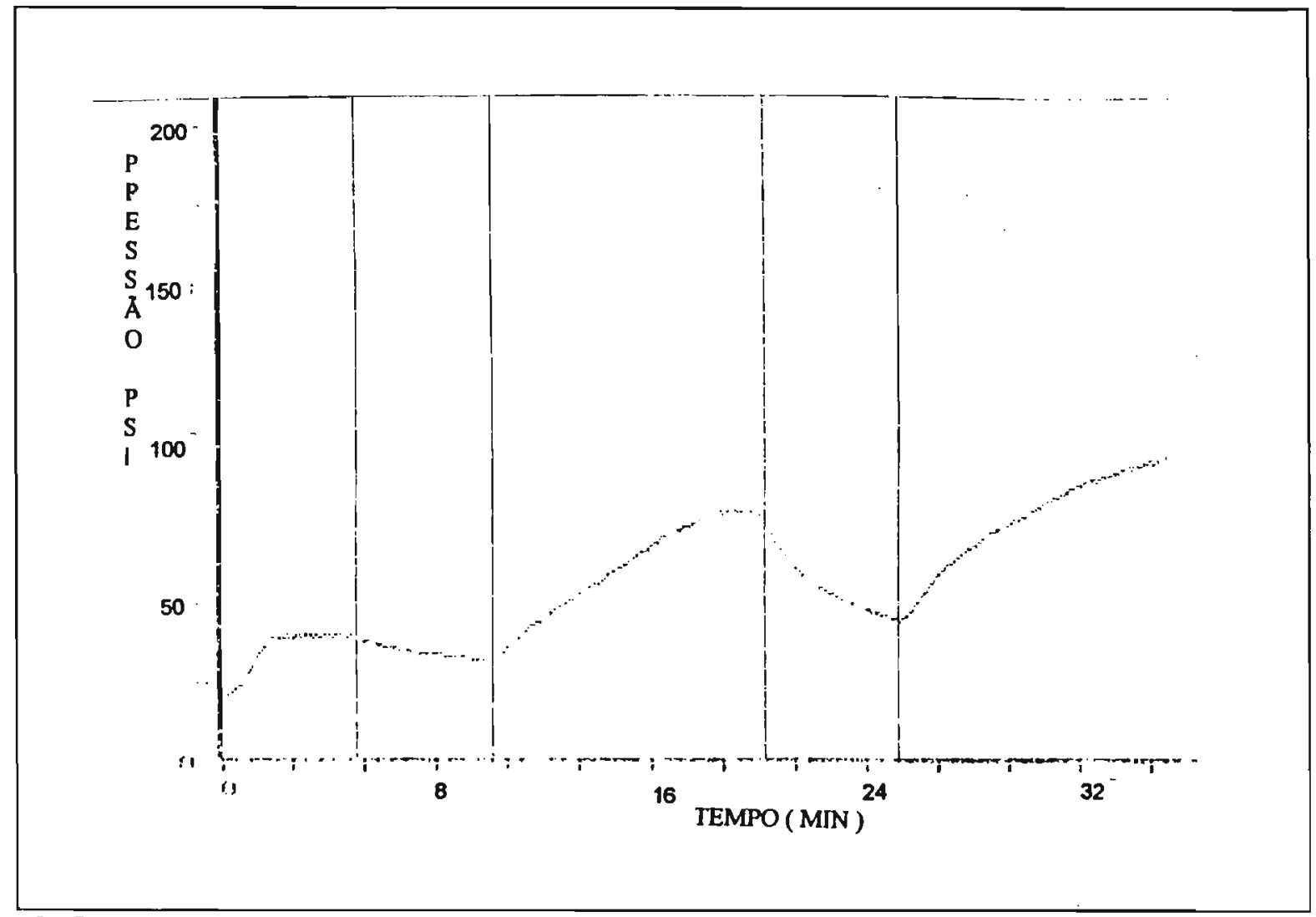

FIGURA 12: Comportamento das amostras de sedimentos do Tietê durante o aquecimento por microondas

Através do gráfico acima, pode-se verificar que as amostras foram submetidas às pressões de 40, 80 e 95 psi, respectivamente, no intervalo estipulado, o que sugere uma eficiência significativa de abertura das amostras. As etapas 2 e 4 (tabela 8) corresponderam a um tempo de repouso das amostras em contato com os ácidos. Aceto et al. ${ }^{(168)}$ observaram que o tempo de repouso entre os aquecimentos foi muito satisfatório na abertura de amostras de sedimentos do Continente Antártico. Após o término do programa de aquecimento e o seu resfriamento, foi observado que muito pouco resíduo restou no fundo do recipiente, mas este resíduo desapareceu após o tratamento com aqueciment na 
presença de $\mathrm{H}_{3} \mathrm{BO}_{3}$. No caso do tratamento na bomba de teflon, observou-se um resíduo muito maior comparado ao obtido com microondas e que não solubilizou completamente após o tratamento à quente, com $\mathrm{H}_{3} \mathrm{BO}_{3}, \mathrm{HClO}_{4}$ e $\mathrm{HCl}$ diluido.

A sílica presente é solubilizada totalmente pela ação do ácido fluorídrico, segundo as reacões ${ }^{(151,152)}$.

$$
\begin{gathered}
\mathrm{SiO}_{2}+6 \mathrm{HF} \rightarrow \mathrm{H}_{2} \mathrm{SiF}_{6}+2 \mathrm{H}_{2} \mathrm{O} \\
\mathrm{H}_{2} \mathrm{SiF}_{6} \rightarrow \mathrm{SiF}_{4}^{\uparrow}+2 \mathrm{HF}
\end{gathered}
$$

Este ataque é facilitado $\mathrm{ccm}$ a presença de $\mathrm{HNO}_{3}$ ou mesmo água régia. No entanto, não é aconselhado o uso de $\mathrm{HCl}$ no microondas, por causa da sua elevada pressão de vapor, que pode causar um aumento abrupto de pressão no sistema.

A eliminação de HF em excesso e a dissolução de fluoretos insolúveis (e altamente estáveis), como os de alumínio, é atingida num tratamento com $\mathrm{H}_{3} \mathrm{BO}_{3}$, segundo as reações ${ }^{(151,152)}$ :

$$
\begin{array}{ll}
\mathrm{H}_{3} \mathrm{BO}_{3}+3 \mathrm{HF} \rightarrow \mathrm{HBF}_{3}(\mathrm{OH})+2 \mathrm{H}_{2} \mathrm{O} & \text { eq. } 3.12 \\
\mathrm{HBF}_{3}(\mathrm{OH})+\mathrm{HF} \rightarrow \mathrm{HBF}_{4}+\mathrm{H}_{2} \mathrm{O} & \text { eq. } 3.13
\end{array}
$$

A etapa lenta da reação é a formação do ácido fluorbórico, que determina a velocidade global da reação. As adições de $\mathrm{HClO}_{4}$ e de $\mathrm{HCl}$ diluído auxiliam a saída dos áciclos remanescentes no recipiente (como o HF), através do aumento da temperatura do sistema ${ }^{(10)}$. As mesmas reações descritas acima ocorrem também no sistema de bomba de teflon.

A determinação dos metais por absorção atômica foi realizada através de curvas padrão $(0,5 ; 1,0 ; 1,5$ e 2,0 ppm $)$ do metal de interesse, em meio de $\mathrm{HCl}$ $1 \%$. 
As figuras 11 a 18 ilustram as curvas obtidas para os padrões de' metais por absorção atômica:

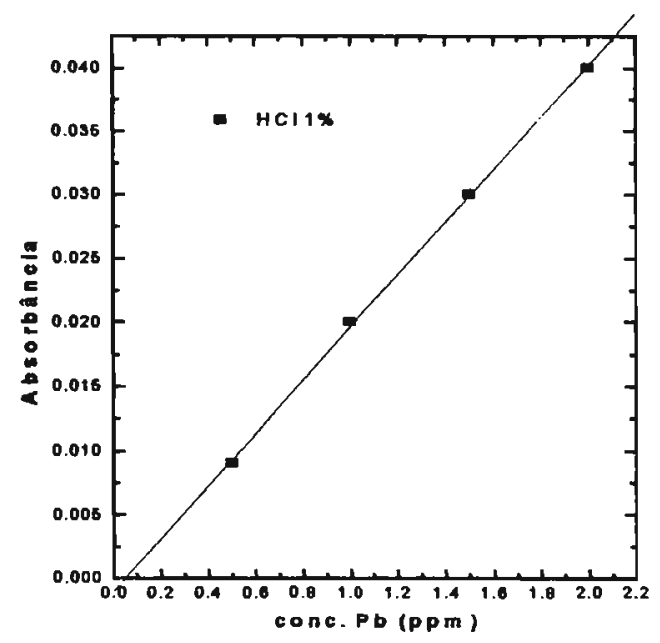

FIGURA 11: curva de calibração de chumbo em HCl 1\%, por absorção atômica.

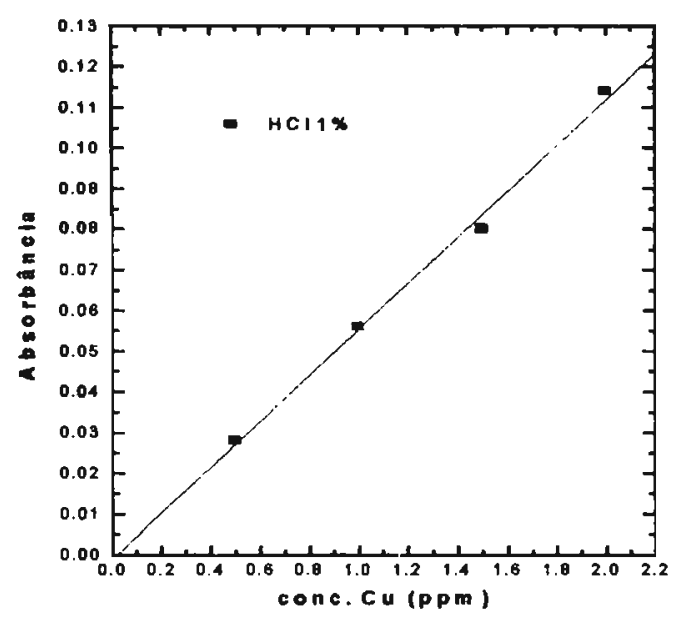

FIGURA 12: curva de calibração de cobre em $\mathrm{HCl} 1 \%$, por absorção atômica. 


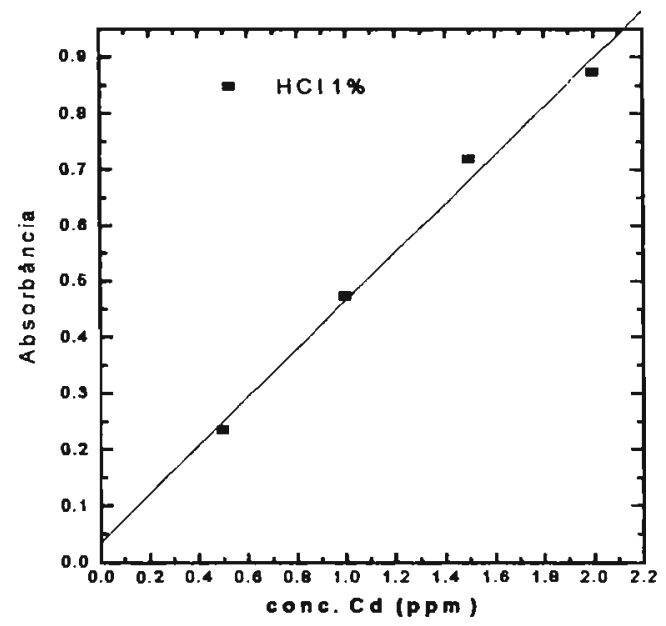

FIGURA 13: curva de calibração de cádmio em HCl 1\%, por absorção atômica.

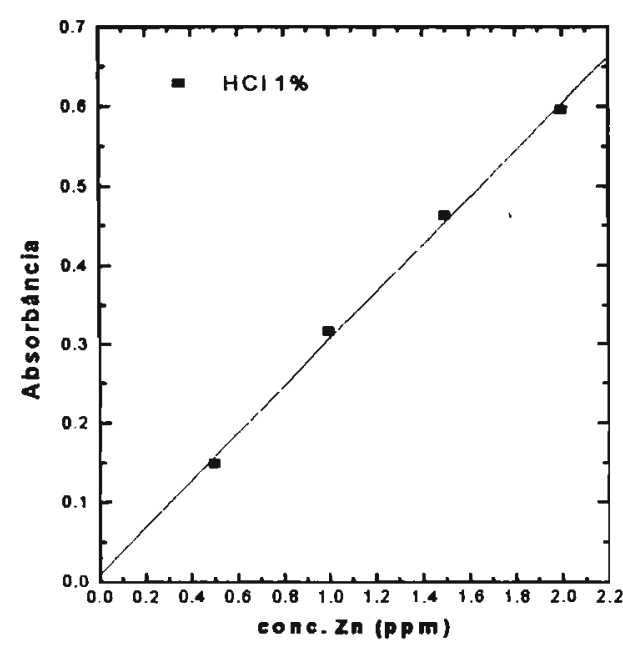

FIGURA 14: curva de calibração de zinco em HCl 1\%, por absorção atômica. 


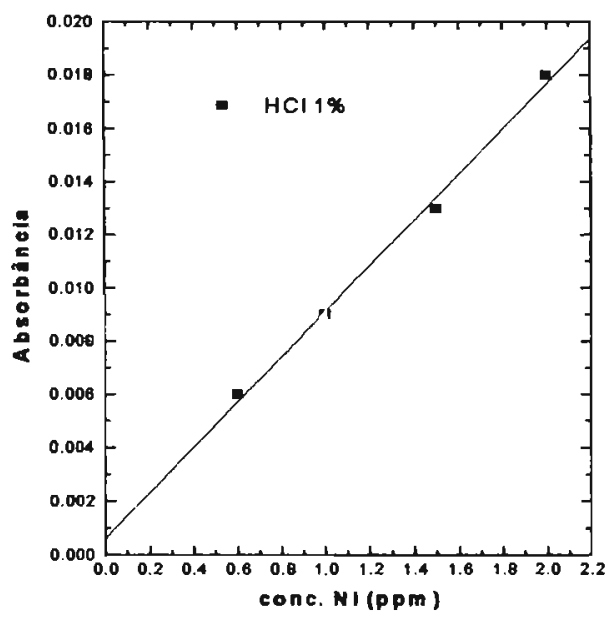

FIGURA 15: curva de calibração de níquel em $\mathrm{HCl}$ 1\%, por absorção atômica.

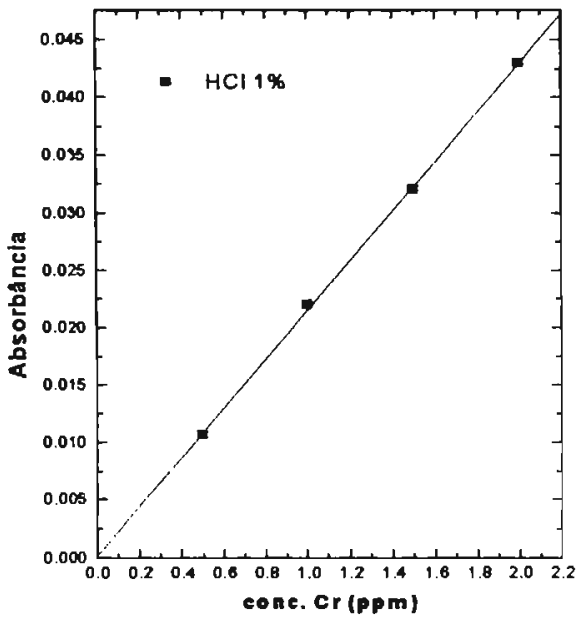

FIGURA 17: curva de calibração de cromo em HCl 1\%, por absorção atômica. 


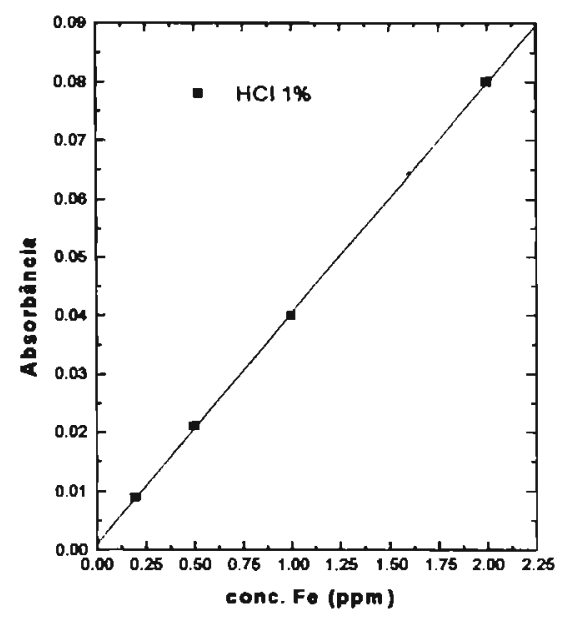

FIGURA 18: curva de calibração de ferro em $\mathrm{HCl}$ 1\%, por absorção atômica.

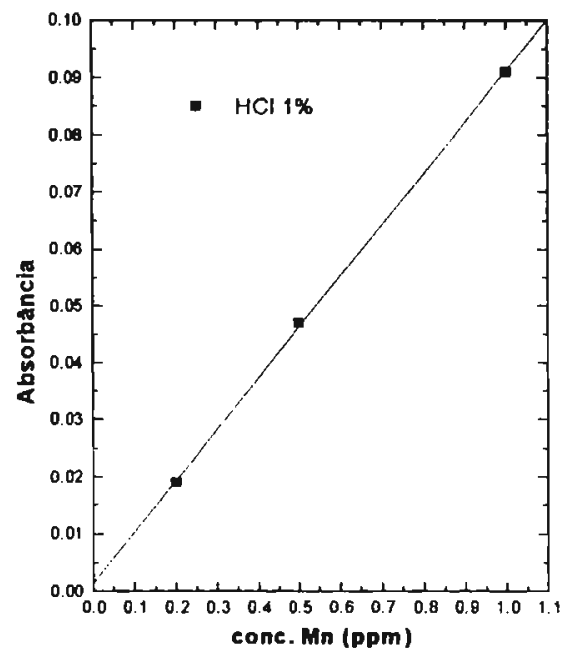

FIGURA 19: curva de calibração de manganês em $\mathrm{HCl}$ 1\%, por absorção atômica.

Os limites de detecção e de determinação dos metais determinados por absorção atômica estão na tabela 11 : 
TABELA 11: valores dos limites de detecção e de determinação dos metais estudados nas amostras de sedimentos.

\begin{tabular}{|c|c|c|}
\hline elemento & $L . D .(\mathrm{mg} / \mathrm{L})$ & L..$(\mathrm{mg} / \mathrm{L})$ \\
\hline $\mathrm{Cu}$ & 0,007 & 0,05 \\
\hline $\mathrm{Cr}$ & 0,014 & 0,1 \\
\hline $\mathrm{Pb}$ & 0,014 & 0,1 \\
\hline $\mathrm{Cd}$ & 0,007 & 0,05 \\
\hline $\mathrm{Zn}$ & 0,0014 & 0,01 \\
\hline $\mathrm{Ni}$ & 0,007 & 0,05 \\
\hline $\mathrm{Fe}$ & 0,014 & 0,1 \\
\hline $\mathrm{Mn}$ & 0,007 & 0,05 \\
\hline
\end{tabular}

O limite de deteç̧ão (L.D.) foi estimado a partir da relação sinal / ruído do equipamento. $O$ limite de quantificação (L.Q.) representa 7 vezes o valor de L.D., conforme recomendação do ASTM-APHA ${ }^{(57)}$, para matrizes ambientais.

A tabela 12 apresenta os resultados obtidos para amostra de sedimentos de casa do Luis (Pirapora) e de entrada de Barra Bonita, pelos métodos de bomba de teflon e de microondas: 
TABELA 12: Resultados obtidos pelo método de microondas e pelo método de bomba de teflon, para as amostras de Pirapora e de Barra Bonita.

\begin{tabular}{|c|c|c|c|c|}
\hline \multirow{2}{*}{ Elemento (ppm) } & \multicolumn{2}{|c|}{ casa do Luís (Pirapora) } & \multicolumn{2}{c|}{ entrada de Barra Bonita } \\
\cline { 2 - 5 } & microondas & $\begin{array}{c}\text { bomba de } \\
\text { teflon } *\end{array}$ & microondas $^{\star}$ & $\begin{array}{c}\text { bomba de } \\
\text { teflon** }\end{array}$ \\
\hline$C u$ & $167,0 \pm 8,3$ & 82,0 & $2,0 \pm 0,3$ & 3,0 \\
\hline$C r$ & $206,0 \pm 6,0$ & 122,0 & $8,00 \pm 0,3$ & 19,0 \\
\hline$P b$ & $259,0 \pm 5,2$ & 232,0 & $25,0 \pm 1,0$ & 17,0 \\
\hline$C d$ & $7,40 \pm 0,2$ & 6,00 & $1,80 \pm 0,1$ & 0,80 \\
\hline$Z n$ & $573,0 \pm 27,0$ & 259,0 & $25,0 \pm 0,3$ & 19,0 \\
\hline$N i$ & $130,0 \pm 4,7$ & 58,0 & $60,0 \pm 1,8$ & 60,0 \\
\hline$F e(\%)$ & $6,3 \pm 1,8$ & 5,2 & $4,0 \pm 1,1$ & 3,6 \\
\hline$M n$ & $167,0 \pm 7,2$ & 174,0 & $412,0 \pm 17$ & 374,0 \\
\hline
\end{tabular}

* resultados de triplicatas de determinaçðes

** resultados de duplicatas de determinaçðes

Os valores obtidos pela técnica de microondas são fruto das médias de triplicata de análises, com a sua correspondente estimativa do desvio padrão. Os resultados de bomba de teflon são as médias obtidas de duplicata de análises. Só foi possível realizar-se duas aberturas por bomba de teflon pelo fato de que o sistema se estragou após a segunda abertura.

Através da tabela acima, pode-se notar que para o método de microondas os valores dos desvios padrão (e dos desvios padrão relativos) foram significativamente baixos, indicando assim uma elevada precisão de análise. No entanto, os resultados obtidos pela bomba de teflon apresentaram diferenças de $50 \%$ entre resultados. Isto se deve ao fato de que o aquecimento é mais homogêneo no interior do forno de microondas que no interior da bomba. A eficiência do sistema de microondas pode ser constatada quando se observam os resultados deste primeiro método, comparados aos resultados da bomba de teflon. Além disso, deve-se considerar que o uso da bomba é inviável, pois o tempo de ataque neste sistema é de $6 \mathrm{hs}$, enquanto que por microondas não é necessário um tempo superior a 30 minutos $^{(168)}$, comprovado também em nossos estudos. 
A fim de se verificar a exatidão do método de abertura proposto, foram realizadas simultaneamente a este estudo, aberturas de um material de referência de sedimento de lago (LKSD-3), do "Canada Centre for mineral and Energy Technology (CANMET)". Foram estudados duas misturas ácidas distintas: A mistura $\mathrm{HCl} / \mathrm{HNO}_{3} / \mathrm{HF}$, a fim de se conhecer os niveis totais dos metais e a mistura $\mathrm{HCl} / \mathrm{HNO}_{3}$, a fim de esclarecer alguns ítens que sucitaram dúvidas na abertura anterior. $\mathrm{O}$ gráfico que representa o comportamento da amostra durante o ataque por microondas está representado na figura 20 :

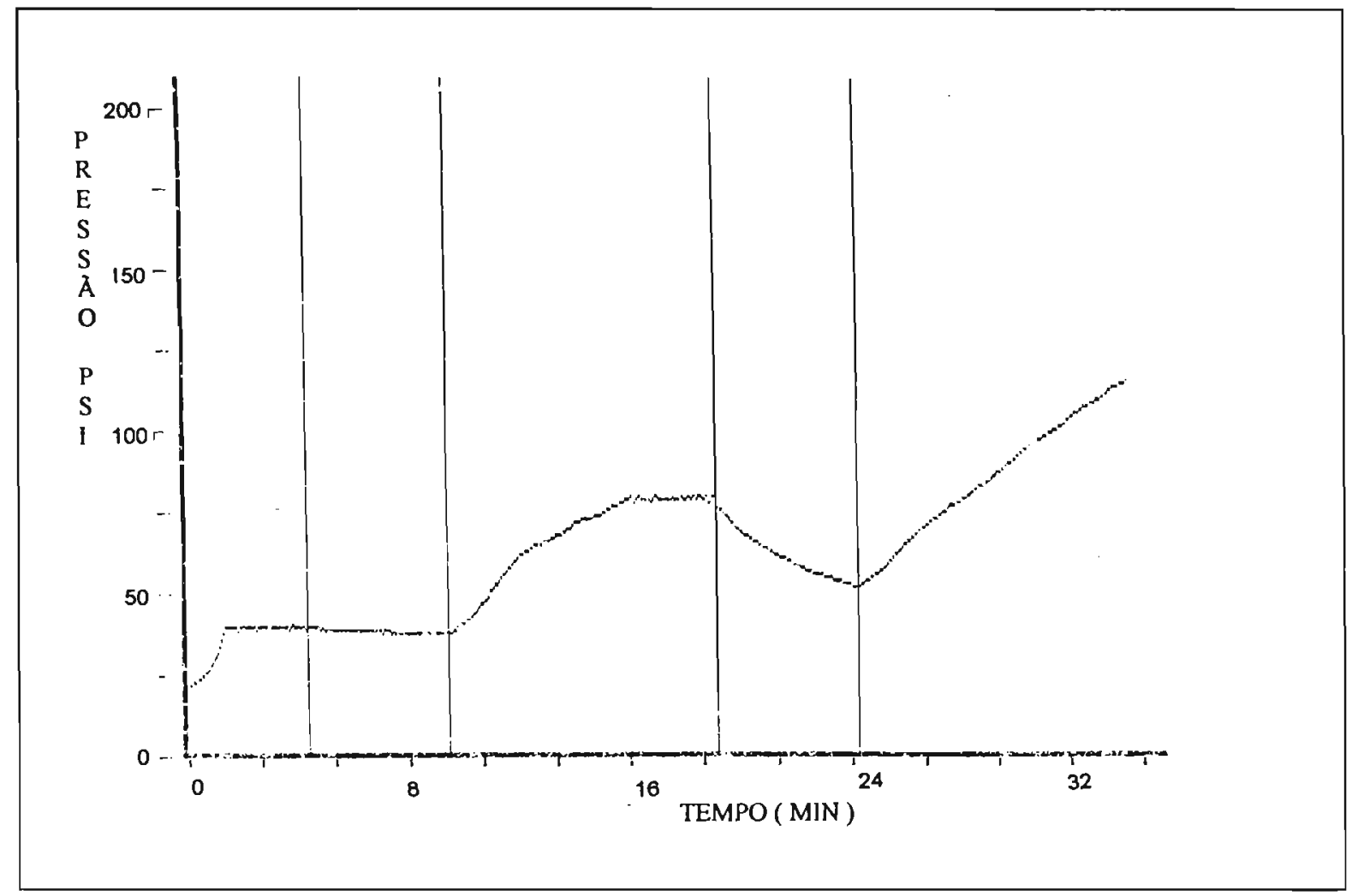

FIGURA 20: Comportamento das amostras de sedimentos de lago (certificado) LKSD 3, durante o aquecimento por microondas

As análises determinações foram realizadas em triplicata ${ }^{(10)}$. Os resultados obtidos para alguns metais de interesse estão a seguir (tabela 13): 
TABELA 13: Resultados obtidos com os materiais de referêcia de sedimentos de lago LKSD-3 (CANMET)

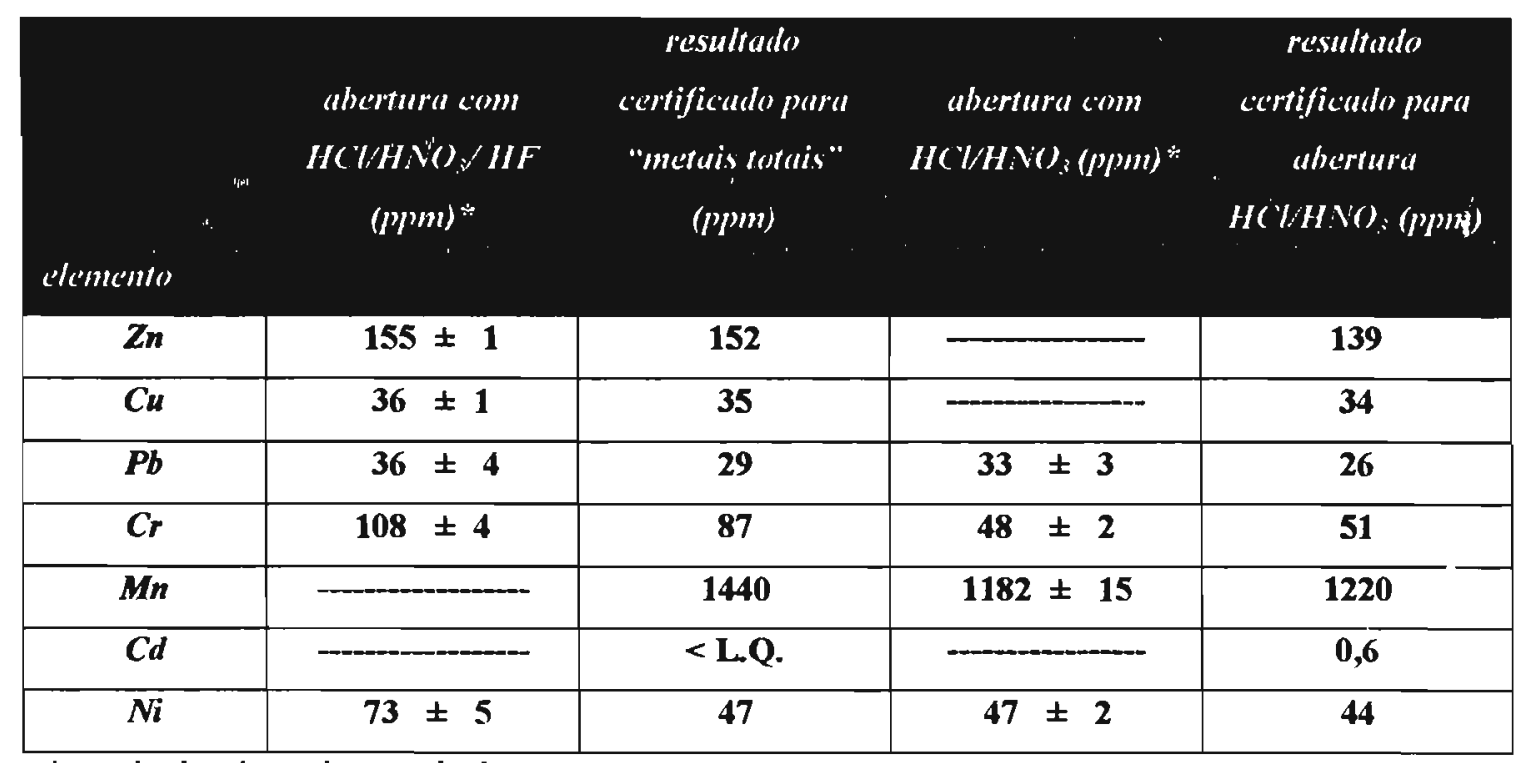

* resultados de triplicatas de determinações

As linhas traçejadas indicam que os elementos não foram determinados. A expressão L.Q. indica que o elemento não pode ser determinado nessas condições, pois caso ele esteja presente na amostra, sua concentração é menor que o limite de quantificação do método. No caso das aberturas realizadas com $\mathrm{HCl} / \mathrm{HNO}_{3} / \mathrm{HF}$, nenhum resíduo foi verificado após o aquecimento em microondas. No entanto, no tratamento com $\mathrm{HCl} / \mathrm{HNO}_{3}$, foi verificada uma quantidade significativa de resíduo, decorrente da sílica e/ou silicatos presentes neste sedimento $(58,5 \%)$, que não são solubilizados por esta mistura de ácidos. Isto torna esta abertura bastante difícil de ser realizada, pois há a necessidade de se filltrar este resíduo, levando para isto algumas horas. Com isso, a transferência quantitativa do analito exige o uso de uma quantidade apreciável de água. Além do tempo adicional gasto (devido à filtração da amostra), a análise dos elementos presentes em baixas concentrações fica prejudicada, por causa da diluição da amostra para $50,00 \mathrm{~mL}$.

Com relação aos metais de interesse presentes nas amostras, pode-se notar que na abertura com $\mathrm{HCl} / \mathrm{HNO}_{3} / \mathrm{HF}$, há uma concordância significativa 
dos resultados para $\mathrm{Zn}$ e Cu. No caso do chumbo, o desvio observado ocorre por causa das baixas leituras de absorbância, muito próximas às correspondentes ao limite de quantificação deste elemento, pela técnica de absorção atômica por chama. Nota-se ainda que os resultados obtidos para o cromo (108 ppm) e para o níquel (73 ppm) estão acima dos valores ceríificados $(87 \mathrm{ppm}$ e $47 \mathrm{ppm}$, respectivamente). Este fenômeno ocorre por causa do tipo de ataque que está sendo realizado. A mistura $\mathrm{HCl} / \mathrm{HNO}_{3} / \mathrm{HF}$, associada ao tratamento com $\mathrm{H}_{3} \mathrm{BO}_{3}$, é capaz de solubilizar todo o sólido presente, como silicatos e óxidos e consequentemente, metais oclusos em retículos cristalinos da matriz geológica são virtualmente determinados ${ }^{(16)}$. No entanto, o certificado expedido pelo órgão oficial Canadense refere-se somente a elementos "totais" , sem contudo especificar a mistura ácida correspondente aos resultados apresentados, o que sugere que o método desenvolvido neste estudo seja mais eficiente que o método utilizado pelo órgão certificador. Através dos resultados apresentados acima, pode-se considerar que o método proposto para a abertura das amostras de sedimento do Tietê proporciona uma significativa precisão e exatidão a esses resultados.

\subsection{2. implicações dos resultados de metais pesados nos sedimentos do} Tietê.

Os resultados da tabela 9, que tratam dos sedimentos de Pirapora e da entrada de Barra Bonita, confirmam as consideraçōes de Eysink et al. ${ }^{(135)} \mathrm{com}$ relação à contaminação do reservatório de Pirapora por metais pesados.

A fim de se ter uma parâmetro de comparação para sedimentos contaminados, os resultados do Tietê foram comparados com os resultados de concentrações totais de metais em sedimentos, utilizando-se um valor de referência global, folhelho médic (sedimentos não contaminados). ${ }^{(169)}$ A tabela a seguir ilustra esta importante corıparação 
TABELA 14: Comparação dos resultados de metais totais das amostras de Pirapora e de Barra Bonita com os resultados de folhelho médio.

\begin{tabular}{|c|c|c|c|}
\hline $\begin{array}{c}\text { elemento } \\
(\mathrm{ppm})\end{array}$ & Pirapora " & $\begin{array}{l}\text { Burru } \\
\text { Bunitu * }\end{array}$ & $\begin{array}{c}\text { folhelho } \\
\text { médios }\end{array}$ \\
\hline Cu & 167 & 12 & 45 \\
\hline$C r$ & 206 & 8 & 90 \\
\hline$P b$ & 259 & 25 & 20 \\
\hline$\overline{C d}$ & 7,4 & $1, \overline{8}$ & $\mathbf{0 , 3}$ \\
\hline$Z n$ & 573 & 25 & 95 \\
\hline $\mathrm{Ni}$ & 130 & 60 & 68 \\
\hline$F e(\%)$ & 6,3 & 4,0 & 4,7 \\
\hline$M n$ & 167 & 412 & 850 \\
\hline
\end{tabular}

Os valores acima sugerem uma contaminação significativa dos sedimentos de fundo do reservatório de Pirapora por quase todos os metais analisados. Os valores correspondentes a chumbo e cádmio são 13 e 25 vezes superiores aos valores do folhelho médio, considerado o valor de referência de sedimentos não contaminados. Isso implica em dizer que Pirapora está servindo como um ambiente de aporte de metais oriundos da bacia de captação do reservatório e possivelmente redistribuição desses metais para toda a biota aquática do Tietê.

A amostra de entrada de Barra Bonita apresentou valores de metais pesados inferiores aos valores do folhelho médio para: $\mathrm{Cu}, \mathrm{Cr}, \mathrm{Zn}, \mathrm{Ni}, \mathrm{Fe}$ e $\mathrm{Mn}$. O valor encontrado para chumbo (25 ppm) comparado ao do folhelho $(20 \mathrm{ppm})$ não indica que esteja ocorrendo uma contaminação no ambiente de Barra Bonita por este metal. O mesmo diz respeito ao cadmio, que apesar de estar um pouco acima do folhelho médio $(1,8$ e 0,3 ; respectivamente $)$, não representa 
contaminação por fontes antrópicas. Eysink ${ }^{(135)}$ corrobora com esta conclusão, através das análises realizadas com a amostra de entrada de Barra Bonita, não encontrando níveis significativos deste metal nas determinações realizadas.

Os resultados referentes a entrada de Barra Bonita não caracterizam uma contaminação proveniente do reservatório de Pirapora, conforme sugere Eysink ət al. ${ }^{(135)}$ Vale ressaltar que o reservatório de Barra Bonita foi estudado já há algum tempo por Esteves et al..$^{(170)}$ e os resultados compilados recentemente por Esteves e Tolentino ${ }^{(171)}$, na busca de identificar e caracterizar alguns grupos de represas do Estado de São Paulo com base na composição química dos seus sedimentos. A tabela 15 ilustra comparativamente os resultados de metais pesados de Barra Bonita encontrados por Esteves et al. ${ }^{(170)}$ e este estudo:

TABELA 15 : Resultados comparativos de metais pesados do reservatório de Barra Bonita

\begin{tabular}{|c|c|c|}
\hline elemento $(p p m)$ & este estudo $(1996)$ & Esteves et al. (1981) \\
\hline$C u$ & 12 & 27,5 \\
\hline$C r$ & 8 & 8,0 \\
\hline$P b$ & 25 & 23,5 \\
\hline$C d$ & 1,8 & 0,8 \\
\hline$Z n$ & 25 & 25,1 \\
\hline$N i$ & 60 & 5,0 \\
\hline$F e(\%)$ & 4,0 & 0,9 \\
\hline$M n$ & 412 & 403,7 \\
\hline
\end{tabular}

* resultados de triplicatas de análises

Ao se comparar os resultados de entrada de Barra Bonita obtidos neste presente estudo com os resultados de Esteves ${ }^{(170)}$, há cerca de 15 anos atrás, pode-se inferir que os resultados entre dessas duas campanhas são muito semelhantes e portanto, não existem evidências de entrada de metais neste 
reservatório provenientes da bacia de drenagem. Algumas diferenças de resultados entre as duas campanhas podem ser observadas, como é o caso do ferro (4,0 e 0,9\%, respectivamente) e do níquel (60 ppm e 5,0 ppm, respectivamente). No entanto, tais diferenças podem ser decorrentes dos diferentes pontos de amostragem considerados nestes dois estudos. Somado a isto, os valores encontrados em nosso estudo estão de acordo com os valores de sedimentos não contaminados, conforme foi abordado acima. Portanto, nos parece apropriado inferir que não há, verdadeiramente, indícios de contaminação no reservatório de Barra Bonita, proveniente do sistema hídrico do Tietê.

Os resultados acima ressaltam a importância de se dispor de inventários sobre a concentração total dos metais nos sedimentos de fundo. No entanto, este parâmetro só fornece a informação sobre o nivel de estocagem, ou taxa de acumulação desses metais. Deve-se considerar que a acumulação de um determinado metal não pode de per si trazer informações quanto à sua transferência para a biota, sendo necessário estimar a sua potencialidade em ser biodisponivel (item 1.5.). Este estudo será tratado a seguir.

\subsection{3. determinação dos metais pesados potencialmente biodisponíveis}

As extrações dos metais em $\mathrm{HCl}$ diluído, foram testadas nas concentrações de 0,1 e $0,5 \mathrm{M}$. Os resultados obtidos estão na tabela 16 :

TABELA 16: Resultados de metais potencialmente biodisponiveis extraídos em $\mathrm{HCl} 0,1$ e $0,5 \mathrm{M}$.

\begin{tabular}{|c|c|c|c|c|}
\hline \multirow[t]{2}{*}{ metais (ppm) } & \multicolumn{2}{|c|}{ Pirapora } & \multicolumn{2}{|c|}{ Barra Bonita } \\
\hline & $\mathrm{HCl} 0,1 \mathrm{M}$ & $\mathrm{HCl} \mathrm{0,5M}$ & $\mathrm{HCl} \mathrm{0,1} \mathrm{M}$ & $\mathrm{HCl} 0,5 \mathrm{M}$ \\
\hline$P \boldsymbol{P b}$ & $61,0 \pm 3,0$ & $86,0 \pm 5,2$ & $4,50 \pm 0,7$ & $6,50 \pm 0,5$ \\
\hline$Z n$ & $147,0 \pm 7,9$ & $148,0 \pm 8,1$ & $10,70 \pm 1,6$ & $10,10 \pm 0,9$ \\
\hline$C u$ & $121,0 \pm 4,5$ & $127,0 \pm 5,6$ & $5,20 \pm 0,8$ & $5,70 \pm 0,6$ \\
\hline $\mathrm{Cr}$ & $44,0 \pm 5,2$ & $79,0 \pm 7,2$ & $2,40 \pm 0,2$ & $3,30 \pm 0,4$ \\
\hline$C d$ & $4,00 \pm 0,6$ & $4,00 \pm 0,3$ & $<$ L.Q. & $<$ L.Q. \\
\hline$N i$ & $105,5 \pm 8,2$ & $118,0 \pm 9,4$ & $5,80 \pm 0,7$ & $6,20 \pm 0,3$ \\
\hline $\mathrm{Fe}(\%)$ & $1,37 \pm 0,04$ & $1,40 \pm 0,05$ & $1,01 \pm 0,03$ & $1,34 \pm 0,04$ \\
\hline$M n$ & $136 \pm 3,5$ & $142 \pm 4,8$ & $412 \pm 28$ & $406 \pm 22$ \\
\hline
\end{tabular}

* resultados de triplicatas de determinações. 
Com exceção do chumbo e do cromo, os demais elementos apresentaram resultados significativamente semelhantes, para as extrações em $\mathrm{HCl}$ 0,1 e 0,5 M. Diante do observado e pelo fato de que esta extração não deve modificar estruturalmente a amostra, optou-se pelos resultados da extração em $\mathrm{HCl} 0,1 \mathrm{M}$, a fim de se estimar o potencial de biodisponibilidade dos metais ${ }^{(40-46)}$. Vale ressaltar que este estudo tem uma conotação mais dirigida em avaliar possiveis contaminaçōes recentes em sedimentos, que propriamente em estimar biodisponibilidade, obtida a partir de bioensaios. A fim de expressar de forma mais simples o conceito de "metais potencialmente biodisponiveis", foi sugerido um índice denominado "potencial biodisponivel percentual", calculado a partir da razăo:

potencial biodisponivel percentual $=$ metais fracamente ligados ou metais potencialmente biodisponíveis / metais fortemente ligados $\times 100$

A razão entre metais fracamente ligados e metais fortemente ligados pode dar uma idéia melhor sobre a contaminação recente do sedimento, e sua distribuiçăo entre as duas fases. A figura abaixo ilustra os resultados comparativos das duas amostras do Tietê em termos de percentual de metais potencialmente biodisponíveis:

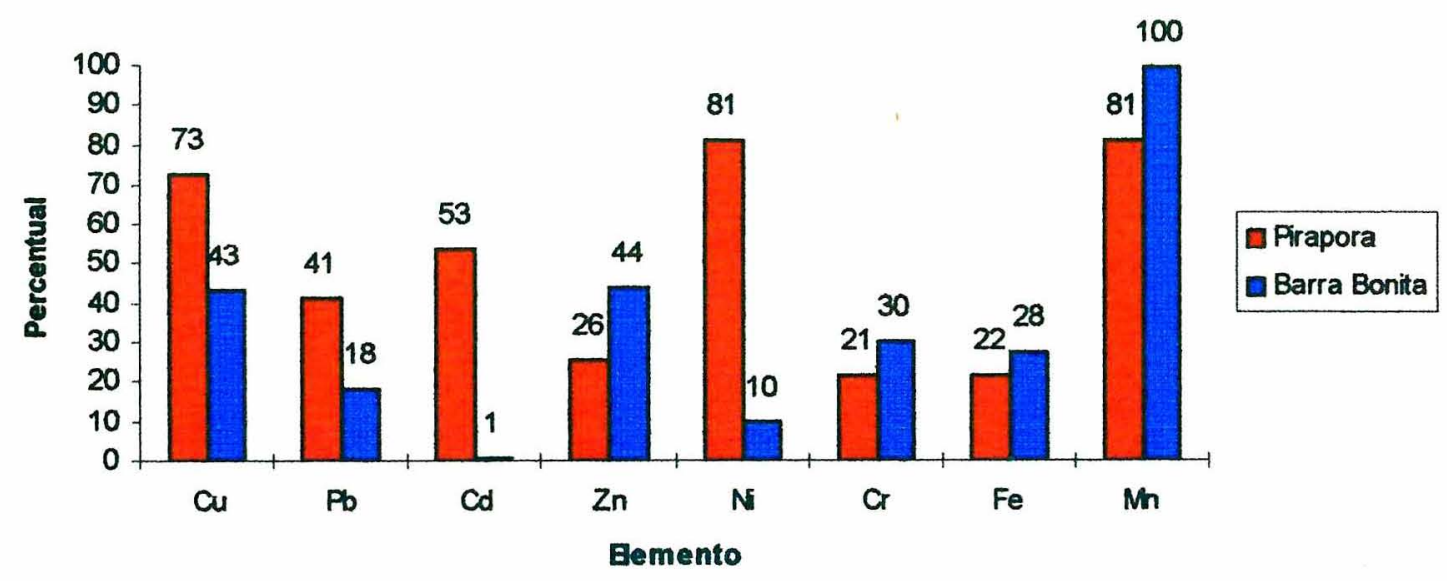

FIGURA 21 : Relação percentual de metais potencialmente biodisponiveis, entre duas amostras de sedimentos do Tietê 
Pode-se considerar que o potencial biodisponível percentual é elevado em Pirapora para a maioria dos metais $(\mathrm{Cu}, \mathrm{Pb}, \mathrm{Cd}$ e $\mathrm{Ni}$ ), o que sugere uma possibilidade significativa de transferência de metais pesados para a biota aquática.

Para a amostra de Barra Bonita, os valores foram mais baixos, porém não negligenciáveis, principalmente para $\mathrm{Cu}$ e $\mathrm{Zn}$. No entanto, deve-se levar em consideração que as concentrações de metais em Pirapora são muito superiores às de de Barra Bonita, como pode-se observar para o chumbo (13,5 vezes maior), zinco (13,7 vezes maior), cobre (23,3 vezes maior), cromo (18,3 vezes maior) e niquel (18,2 vezes maior). Tais considerações ja foram devidamente explanadas no item 372 e na tabela 11, onde ficou claro que o reservatório de Pirapora está muito contaminado por metais pesados, enquanto que Barra Bonita apresenta niveis comparáveis aos do folhelho médio. Portanto, os valores encontrados para a amostra de Barra Bonita não sugerem um possível efeito de contaminação recente, apesar dos valores observados acima.

Com relação ao manganês, pode-se verificar que os resultados são significativamente elevados para as di:as amostras estudadas (81\% em Pirapora e $100 \%$ em Barra Bonita). Pode-se inferir que os valores encontrados para este metal não são um reflexo de seu comportamento na biota aquática, mas sim uma consequência de sua presença rıa matriz do sedimento, como parte do minério pré-existente. O ácido clorídrico, mesmo diluído $(0,1 \mathrm{M})$, foi capaz de atacar a estrutura interna do sedimento, formada por óxidos de ferro (III) e manganês (IV) e dissolveu principalmente este último óxido, numa reação redox (ver adiante, extração sequencial, fração facilmente redutivel). Portanto, os resultados obtidos para manganês não devem ser levados em consideração em termos de contaminação, pois não represeritam a situação real das amostras de sedimentos do Tietê, como ação antropogênica. Além disso, ao se consultar as tabelas 12 e 13, pode-se observar que o nível deste metal está de acordo do que se espera para uma amostra não contamínada, através da comparação com os resultados de folhelho médio. 
Algumas considerações podem ser apontadas com relação ao critério por nós utilizado de metais potencialmente biodisponiveis ${ }^{(40-46)}$ : Através da tabela 7 , que mostra os resultados de sulfeto ácido volátil, verifica-se que a amostra de Pirapora (casa do Luís) apresenta uma concentração de 14423 ppm (que corresponde a $450 \mu \mathrm{mols} / \mathrm{g}$.sedimento) e entrada de Barra Bonita somente 104 ppm $(3,24 \mu \mathrm{mols} / \mathrm{g}$.sedimento). Têm-se que, a princípio, o sulfeto e o polissulfeto são as espécies que predominantemente controlam a concentração dos metais presentes no sedimento de Pirapora, quando se compara com a amostra de Barra Bonita, que apresenta uma concentração de sulfetos $e$, consequentemente po'issulfetos, 139 vezes menor. Entretanto, os sulfetos dos metais em questão são muito pouco solúveis, conforme mostra a tabela abaixo:

TABELA 17: produtos de solubilidade de alguns sulfetos insolúveis ${ }^{(84)}$

\begin{tabular}{|c|c|c|}
\hline sulfeto do metal & $K p s$ & soslubilidacte \\
\hline FeS (mackinawita) & $4,07.10^{-23}$ & $6,38.10^{-12}$ \\
\hline NiS (millerita) & $1,05.10^{-28}$ & $1,02.10^{-14}$ \\
\hline$\overline{Z n S}$ (wurtzita) & $4,07.10^{-29}$ & $6,38.10^{-15}$ \\
\hline CdS (greenockita) & $1,41.10^{-33}$ & $3,75.10^{-17}$ \\
\hline PbS (galena) & $3,80.10^{-34}$ & $1,95.10^{-17}$ \\
\hline CuS (covellita) & $1,15.10^{-41}$ & $3,39.10^{-21}$ \\
\hline HgS (cinábrio) & $5,62.10^{-58}$ & $2,37.10^{-29}$ \\
\hline
\end{tabular}

No caso do cromo, verifica-se por hidrólise, na realidade, a formação do hidróxido insolúvel correspondente $\left(\mathrm{Ks}=6,3 \times 10^{-31}\right.$ )

Se forem comparados os valores de solubilidade da tabela acima e os resultados da tabela 14, que trata dos metais potencialmente biodisponíveis, há uma significativa discordância entre esses resultados, pois o tratamento com ácido clorídrico diluído deve dissolver, em princípio somente os seguintes 
sulfetos: FeS; $\mathrm{ZnS} ; \mathrm{MnS}$, além de $\mathrm{Cr}(\mathrm{OH})_{3}$, o que torna difícil sugerir uma explicação plausivel dos resultados observados para $\mathrm{Cd}, \mathrm{Pb}, \mathrm{Cu}$ e Ni. Contudo, a presença de íon polissulfeto pode manter alguns metais complexados totalmente ou em parte e os complexos adsorvidos no sedimento. Experimentos qualitativos por nós realizados mostraram que, em pH 7,0-8,0, íns $\mathrm{Cu}^{2+}$ sofrem precipitação, com posterior complexação, quando tratados com excesso de íons de polissulfeto e que íons $\mathrm{Pb}^{+}{ }^{+} \mathrm{Ni}^{2+}$ sofrem precipitação parcial. Assim, a adição de $\mathrm{HCl} \mathrm{0,1} \mathrm{M}$ a frio, conforme o critério adotado(40-46), deve liberar em grande parte os metais complexados. Além disso, outras fases internas (ver extração sequencial) como os óxidos redutíveis, também podem liberar os metais pesados com o ataque redox dos óxidos, especialmente $\mathrm{MnO}_{2}$, em ácido diluído, aumentando a fração solúvel e consequentemente biodisponivel. Os estudos realizados até 0 presente foram importantes e esclarecedores com relação à presença e ao potencial de biodisponibilidade dos metais presentes nos sedimentos. A fim de caracterizar-se de forma mais abrangente a associação destes metais nos sedimentos, decidiu-se por aplicar o método de extração sequencial para estas duas amostras (casa do Luis e entrada de Barra Bonita).

\subsection{4. extração sequencial - método de Kersten e Förstner}

A seguir, serão apresentados as condições estabelecidas para o estudo dos metais nas matrizes constituídas no método de extração sequencial.

\subsubsection{1.estabelecimento das condições de medida por espectrofotometria de absorção atómica}

As curvas padrão dos metais foram construidas com padrões do metal de interesse, nas concentrações de 0,$5 ; 1,0 ; 1,5$ e 2,0 ppm. Os metais ferro e manganês tiveram que ser excluídos dos estudos de extração sequencial por causa de problemas de precipitação desses metais durante a estocagem das amostras ( conforme será visto adiante), e também por serem constituintes fundamentais da matriz mineralógica dos sedimentos. Para cada etapa de 
extração, os padrōes foram elaborados com a sua respectiva solução de extração. Isto foi realizado baseando-se nas consideraçōes de Fiedler ${ }^{(10)}$ a respeito dos efeitos de matriz observados na análise de metais por absorção atômica. A seguir, serão apresentadas as curvas de calibração para os metais estudados pelo metodo de extração sequencial.

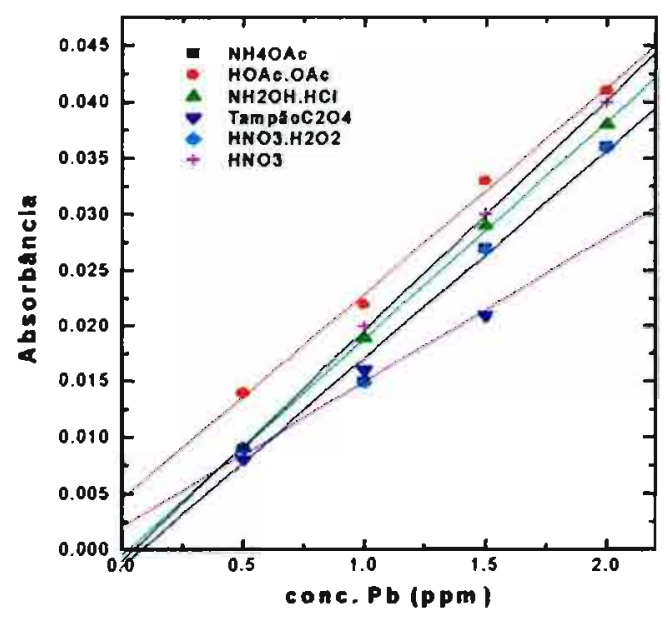

FIGURA 22: efeitos de matriz em curvas de calibração de soluções padrão de chumbo, considerando-se as extrações sequenciais.

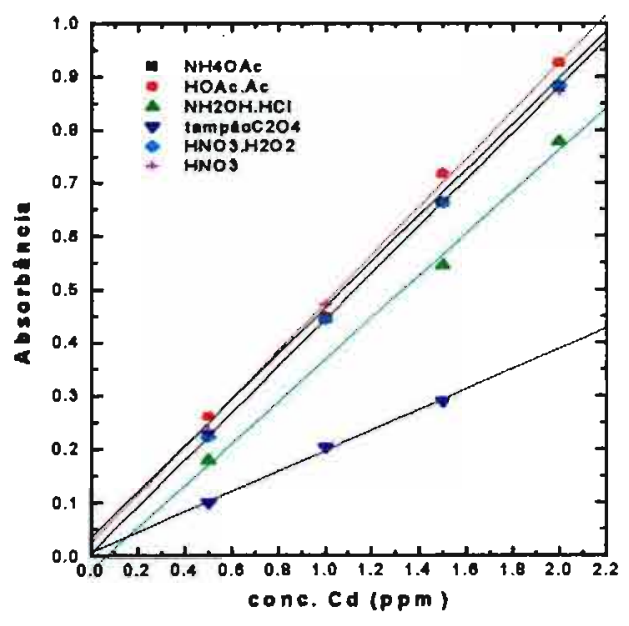

FIGURA 23: efeitos de matriz em curvas de calibração de soluções padrão de cádmio considerando-se as extraçőes sequenciais. 


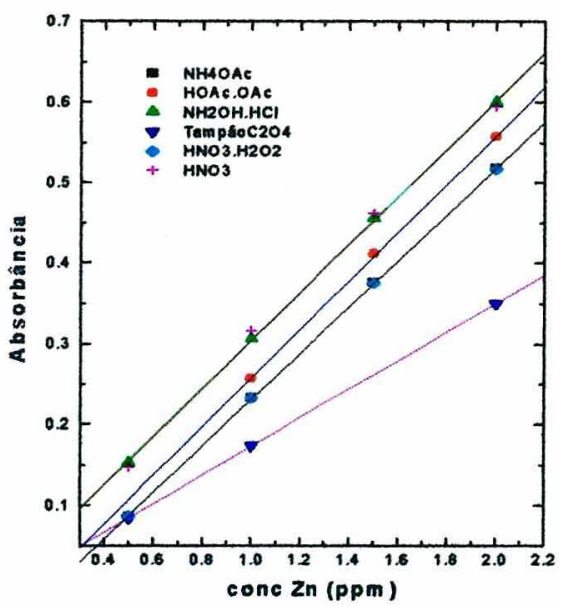

FIGURA 24: efeitos de matriz em curvas de calibração de soluções padrão de zinco, considerando-se as extrações sequenciais.

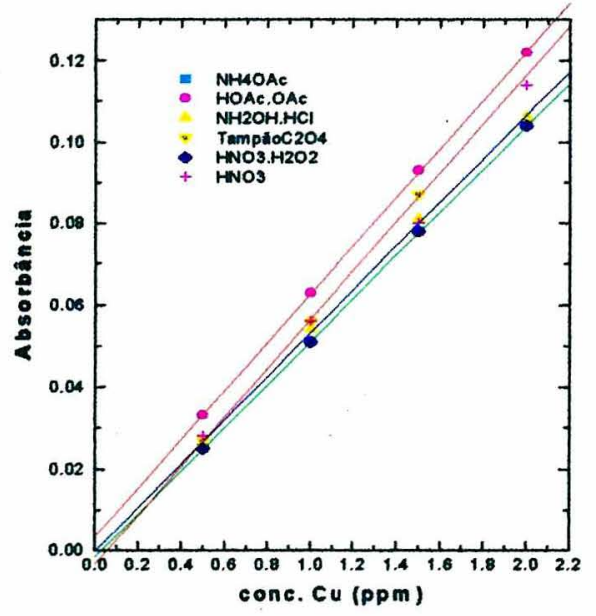

FIGURA 25: efeitos de matriz em curvas de calibração de soluções padrão de cobre, considerando-se as extrações sequenciais. 


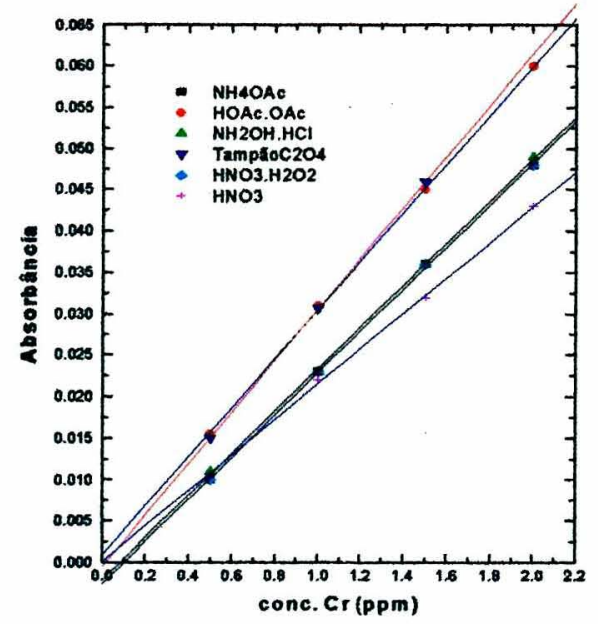

FIGURA 26: efeitos de matriz em curvas de calibração de soluções padrão de cromo, considerando-se as extrações sequenciais.

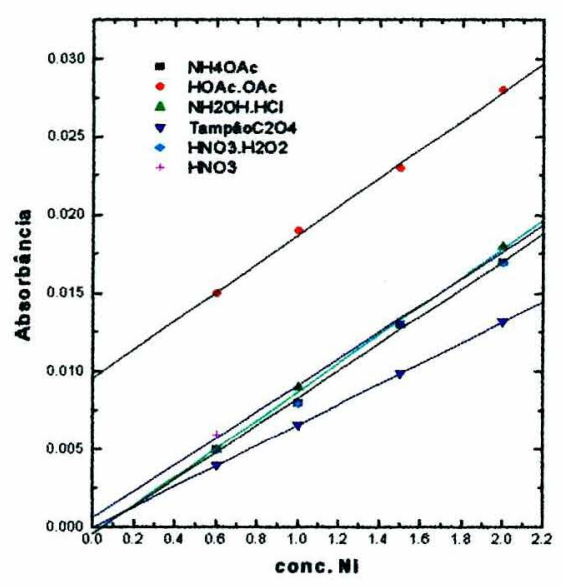

FIGURA 27: efeitos de matriz em curvas de calibração de soluções padrão de níquel, considerando-se as extrações sequenciais.

O efeito de matriz pode ser constatado ao se observar uma alteração no coeficiente angular de uma determinada reta, quando comparada a uma reta 
obtida, por exemplo, em meio de $\mathrm{HCl} 1 \%$. No caso das curvas acima, pode-se considerar que, de um modo geral, os reagentes não causaram efeitos de matriz significativos às determinações por absorção atômica. Alguns efeitos foram constatados para o chumbo (etapa 4, tampão oxalato), cádmio (etapas 3 e 4, cloreto de hidroxilamônio e tampão oxalato, respectivamente), zinco (etapa 4 , tampão oxalato), níquel (etapa 4, tampão oxalato) e cromo (etapa 6 , ácido nítrico). Os reagentes de extração não causaram efeitos de matriz para os íons cobre. 0 tampão acetato apresentou uma ligeira contaminação por $\mathrm{Ni}$, realizando-se portanto o desconto devido nos cálculos de concentração.

O tampão oxalato foi o principal causador de efeitos de matriz nas determinações realizadas neste estudo. Com exceção do níquel, todos os demais elementos apresentaram problemas com este reagente, tendo inclusive que se construirem as curvas desses metais com somente 3 dos 4 padrões, tamanhos foram os desvios observados. Ao se constatar tais problemas, as amostras correspondentes à etapa 4 foram as últimas a serem analisadas, devido à grande quantidade de resíduos sólidos que deixaram no queimador. Uma explicação plausivel para os problemas causados por este reagente está na possível formação de compostos estáveis na chama advindos da decomposição de oxalato na solução. A formação de carbonatos propiciam uma cinética de decomposição desfavorável na chama, causando assim efeitos de matriz tão pronunciados quanto os verificados para os padrões compostos com tampão oxalato e seus extratos. No caso das amostras, além dos efeitos causados pelo tampão oxalato, ocorreram problemas decorrentes da formação de oxalato de cálcio no queimador e a sua posterior decomposição na chama, formando o óxido correspondente, que é termicamente mais estável.

A partir das leituras das amostras por absorção atômica, foram calculadas as concentrações dos metais em cada fase. Os resultados encontrados para as amostras de Pirapora (casa do Luís) estão a seguir: 
TABELA 18: resultados do método de extração sequencial para a amostra de Pirapora. metais, ppm.

\begin{tabular}{|c|c|c|c|c|c|c|}
\hline etupu n" & $P b:$ & $C u \div$ & $Z n *$ & $C d:$ & $N i *$ & $C r$ \\
\hline $1-\mathrm{NH}_{4} \mathrm{OAC}$ & $<$ L.Q. & $<$ L.Q. & $3,5 \pm 2$ & <L.Q. & $17 \pm 3$ & $<$ L.Q. \\
\hline 2- $\mathrm{HOAc/OAc-}$ & $<$ L.Q. & $<$ L.Q. & $10 \pm 5$ & $<$ L.Q. & $24 \pm 3$ & $<$ L.Q. \\
\hline 3- $\mathrm{NH}_{2} \mathrm{OH} . \mathrm{HCl}$ & $<$ L.Q. & $<$ L.Q. & $90 \pm 25$ & $1,8 \pm 0,3$ & $24 \pm 4$ & $<$ L.Q. \\
\hline $4-\mathrm{H}_{2} \mathrm{C}_{2} \mathrm{O}_{4} / \mathrm{C}_{2} \mathrm{O}_{4}^{2-}$ & $24 \pm 3$ & $17 \pm 2$ & $120 \pm 14$ & $0,6 \pm 0,2$ & $29 \pm 4$ & $48 \pm 4$ \\
\hline $5-\mathrm{HNO}_{3} / \mathrm{H}_{2} \mathrm{O}_{2}$ & $43 \pm 10$ & $86 \pm 8$ & $106 \pm 24$ & $1,9 \pm 0,2$ & $12 \pm 2$ & $56 \pm 5$ \\
\hline $6-\mathrm{HNO}_{3}$ & $19 \pm 9$ & $29 \pm 4$ & $40 \pm 10$ & $<\mathbf{L . Q}$. & $15 \pm 3$ & $30 \pm 5$ \\
\hline$\overline{\sum 1 a 6}$ & 86 & 132 & 369,5 & 4,3 & 121 & 134 \\
\hline abert. $\mathrm{HNO}_{3} / \mathrm{H}_{2} \mathrm{O}_{2}$ & $89 \pm 22$ & $135 \pm 21$ & $335 \pm 35$ & $4,5 \pm 0,4$ & $131 \pm 5$ & $115 \pm 31$ \\
\hline
\end{tabular}

* resultados de triplicatas de determinações

Os valores acima foram obtidos a partir de uma triplicata de determinações. Pode-se considerar que os desvios encontrados não foram elevados, embora os resultados encontrados para a somatória de todas as etapas concordem satisfatoriamente com os resultados da abertura total para esta amostra, numa margem de erro de $10 \%$, conforme foi observado por Kersten e Förstner ${ }^{(35,36)}$.

Os resultados encontrados para a amostra de entrada de Barra Bonita estão a seguir: 
TABELA 19: resultados do método de extração sequencial para a amostra de entrada de Barra Bonita.

metais, ppm.

\begin{tabular}{|c|c|c|c|}
\hline ctupu $n^{\prime \prime}$ & & & $u$ \\
\hline $1-\mathrm{NH}_{4} \mathrm{OAC}$ & $<$ L.Q. & $<$ L.C. & < L.Q. \\
\hline 2- $\mathrm{HOAc} / O A c-$ & $<$ L.Q. & $<$ L.Q. & $<\mathbf{L} \cdot \mathbf{Q}$ \\
\hline 3- $\mathrm{NH}_{2} \mathrm{OH} . \mathrm{HCl}$ & $<$ L.Q. & $11,5 \pm 3,6$ & < L.Q. \\
\hline $4-\mathrm{H}_{2} \mathrm{C}_{2} \mathrm{O}_{4} / \mathrm{C}_{2} \mathrm{O}_{4}{ }^{2-}$ & $1,8 \pm 0,4$ & $6,5 \pm 1,2$ & $4,6 \pm 0,2$ \\
\hline $5-\mathrm{HNO}_{3} \overline{\mathrm{H}}_{2} \mathrm{O}_{2}$ & $2,2 \pm 0,8$ & $2,5 \pm 0,4$ & $2,4 \pm 0,7$ \\
\hline $6-\mathrm{HNO}_{3}$ & $4,0 \pm 0,7$ & $4,5 \pm 1,8$ & $5,0 \pm 1,3$ \\
\hline$\sum 1 a 6$ & 8,0 & 25,0 & 12,0 \\
\hline abert. $\mathrm{HNO}_{3} / \mathrm{H}_{2} \mathrm{O}_{2}$ & $7,0 \pm 1,2$ & $14,0 \pm 2,1$ & $8,5 \pm 1,8$ \\
\hline
\end{tabular}

* resultados de triplicatas de determinações

Assim como foi verificado na amostra de Pirapora(casa do Luís), a amostra de entrada de Barra Bonita apresentou desvios significativamente elevados. Consideramos que, tais desvios estão associados ao procedimento de extração, que envolve um número muito grande de etapas (ver figuras 28 e 29).

Será discutido a seguir os problemas que envolvem o método de extração adotado para as amostras do Tietê.

\subsubsection{2. particularidades experimentais sobre o método de extração sequencial adotado}

As amostras de sedimento estudadas pertencem a duas classes distintas: a de Pirapora (casa do Luís, Rasgão e Tecelagem, respectivamente) é negra e extremamente fina, típica de ambientes anóxidos e sulfídricos, conforme foi discutido anteriormente. Já a amostra de entrada de Barra Bonita é clara, de aspecto arenoso e apresenta uma granulometria muito diferente de Pirapora, 
sendo portanto muito mais fácil de manuseá-la. A transferência destas amostras para o frasco de extração e a extração em atmosfera inerte são etapas tediosas, que exigem muito cuidado, para não expô-las ao ar. Alguns pontos serão apresentados com relação às etapas de extração:

- $1^{\text {a }}$ etapa (metais ou íons trocáveis): foi observado que a amostra permaneceu escura (negra) durante a extração, o que de certo modo reflete o cuidado de mantê-la em condição anaeróbica. Após o tempo preconizado para a extração ( \pm 2 horas), tem-se que aguardar muitas horas para que o substrato sólido sedimente no fundo do frasco. Para a amostra de Barra Bonita a sedimentação foi muito mais rápida. Caso não se aguarde o tempo necessário de sedimentação, as etapas de remoção do sobrenadante e de filtração ficam sensivelmente prejudicadas.

A amostra (do extrato com acetato de amônio) de Pirapora apresentou durante a sua estocagem a $4^{\circ} \mathrm{C}$, uma coloração amarelada que em poucos dias resultou numa precipitação intensa. Este precipitado foi identificado contendo hidróxido de ferro, a partir do teste com tiocianato de amônio em meio ácido (coloração vermelha) e manganês (IV), a partir do teste com benzidina em presença do sal de Rochele, tartarato de sódio e potássio ( a fim de se evitar a precipitação do hidróxido de ferro presente), conforme descreve Feigl ${ }^{(172)}$. Neste caso, o sólido foi dissolvido em quantidade suficiente de $\mathrm{HCl}$ diluído e verificou-se uma forte coloração azul, confirmando-se assim a presença de manganês.

Com isto, pode-se inferir que a adição de EDTA na concentração recomendada, aos extratos, quando a concentração de ferro e de manganês forem elevadas como são as de Pirapora, não evita a precipitação de seus hidróxidos. Vale ressaltar que foi adicionada uma quantidade superior de EDTA (cerca de $150 \mathrm{mg}$ ) à recomendada no método de extração de Kersten e Förstner ${ }^{(35,36)}(50 \mathrm{mg})$, não resultando em bons resultados; 
$2^{\mathrm{a}}$ etapa (metais ligados a carbonatos): nesta etapa de extração foi verificado que a amostra de Pirapora (casa do Luís) continuou com sua coloração original (negra). Com relação ao extratos finais desta vez foi verificada uma coloração amarelada tanto no extrato correspondente a Pirapora, quanto no extrato da amostra de Barra Bonita. $\mathrm{O}$ fenômeno de precipitação foi observado nestas duas amostras e os testes foram positivos novamente para ferro (III) e para manganês(IV). Com isso, valem as considerações feitas acima, de que a quantidade de EDTA, mesmo excedendo à recomendada, não evita a precipitação destes dois metais.

O tempo de sedimentação foi estimado em cerca de 6 horas, para amlıas as amostras;

$3^{\mathrm{a}}$ etapa (metais associados a óxidos facilmente redutíveis, como óxidos de manganês) : nesta etapa, foi observada uma coloração mais clara tanto na amostra de Pirapora, quanto na amostra de Barra Bonita e o precipitado de hidróxido de ferro e de dióxido de manganês em ambas as amostras, após alguns poucos dias de estocagem. Com relação ao tempo de sedimentação, foi verificado que, assim como no extrato anterior, 6 horas foram suficientes para uma sedimentação completa da amostra. Some-se a este tempo de sedimentação mais 6 horas, pois é necessária uma lavagem da amostra para continuação do procedimento de extração;

$4^{a}$ etapa (metais associados a óxido moderadamente redutível, como óxidos de ferro amorfos): pôde-se verificar nesta etapa da extração que o sedimento sofre uma mudança estrutural completa (em ambas as amostras), passando a apresentar um aspecto coloidal e uma coloração amarela intensa. Pelo fato de haver uma grande modificação na amostra, a sedimentação fica bastante comprometida. Isto ocorre, segundo Förstner ${ }^{(9)}$, porque os óxidos de ferro agem nos sedimentos como "cimento" para agregar as demais partículas adsorvidas ${ }^{(9)}$. 
Portanto, com a destruição desse "cimento", há um aumento significativo da área de adsorção decorrente da desagregação das partículas que estavam originalmente adsorvidas. Para se ter uma idéia da dificuldade em realizar-se esta etapa de extração, tem-se que aguardar no mínimo 3 dias para haver uma sedimentação satisfatória e como nesta etapa é necessário executar a lavagem do sedimento para prosseguir as extrações, mais 3 dias de sedimentação devem novamente ser aguardados. Foi observado que qualquer perturbação no frasco, por menor que seja, causa uma redistribuição do sólido. Do mesmo modo o recolhimento do sobrenadante e a filtração são extremamente tediosas (cada filtro tem capacidade de filtrar $\sim 20 \mathrm{~mL}$ de suspensão) e difíceis de serem realizadas a contento. Corre-se inclusive o risco de se perder quantidades significativas de material nesta etapa de extração, incorrendo assim em erros analíticos significativos;

$5^{\mathrm{a}}$ etapa (metais ligados a sulfetos e detritos de matéria orgânica) : A partir da $4^{\mathrm{a}}$ extração, não há mais a necessidade de se trabalhar no interior do glove-box. $O$ material foi tratado à quente procurando-se manter a temperatura a $85^{\circ} \mathrm{C}$, por causa da evolução de $\mathrm{O}_{2}$ durante a ação de $\mathrm{H}_{2} \mathrm{O}_{2}$ na amostra. Foi verificado que na amostra de Pirapora houve uma intensa evolução de $\mathrm{O}_{2}$ (decorrente de sua decomposição induzida), por cerca de 15 minutos, devido à grande quantidade de sulfetos presentes na amostra, enquanto que para a amostra de Barra Bonita essa evolução foi bem menor. Tornou-se necessária a introdução de um capilar de vidro a fim de quebrar a tensão superficial das bolhas formadas. Esta etapa é, assim como a etapa 4, bastante tediosa, pois o material é levado à secura durante um tempo de aproximadamente 5 horas e recuperado em uma solução de $\mathrm{NH}_{4} \mathrm{OAc}+\mathrm{HNO}_{3}(6 \%)$, sob agitação por 12 horas, além do tempo de sedimentação, estimado em 8 horas;

$6^{\mathrm{a}}$ etapa (metais ligados à fase residual ou metais cristalinos litogênicos)

Após a etapa 5, tanto o material de Pirapora, quanto o de Barra Bonita, apresentaram uma coloração clara, tendendo a um tom creme e branco, 
respectivamente. Ao se encerrar o tratamento ácido, observou-se um aspecto ainda leitoso na amostra de Pirapora, enquanto que para a amostra de Barra Bonita o aspecto foi o de grãos de areia muito claros. A sedimentação foi relativamente rápida comparada às etapas 4 e 5 , cerca de 2 horas.

Com relação à abertura total, os mesmos cuidados observados para a etapa 5 foram considerados nesta etapa, por causa da ação de $\mathrm{H}_{2} \mathrm{O}_{2}$ nas amostras, e forte evolução de $\mathrm{O}_{2}$.

\subsubsection{3. discussão dos resultados obtidos por extração sequencial}

Serão apresentados a seguir os resultados da distribuição dos metais nas "fases" que compõem o sedimento de Pirapora, segundo o método de Kersten e Förstner ${ }^{(35,36)}$. A figura 28 ilustra os resultados obtidos:

BIBLIOTECA WSTITUTO DE CUIMICA

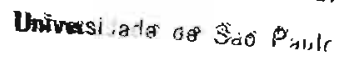



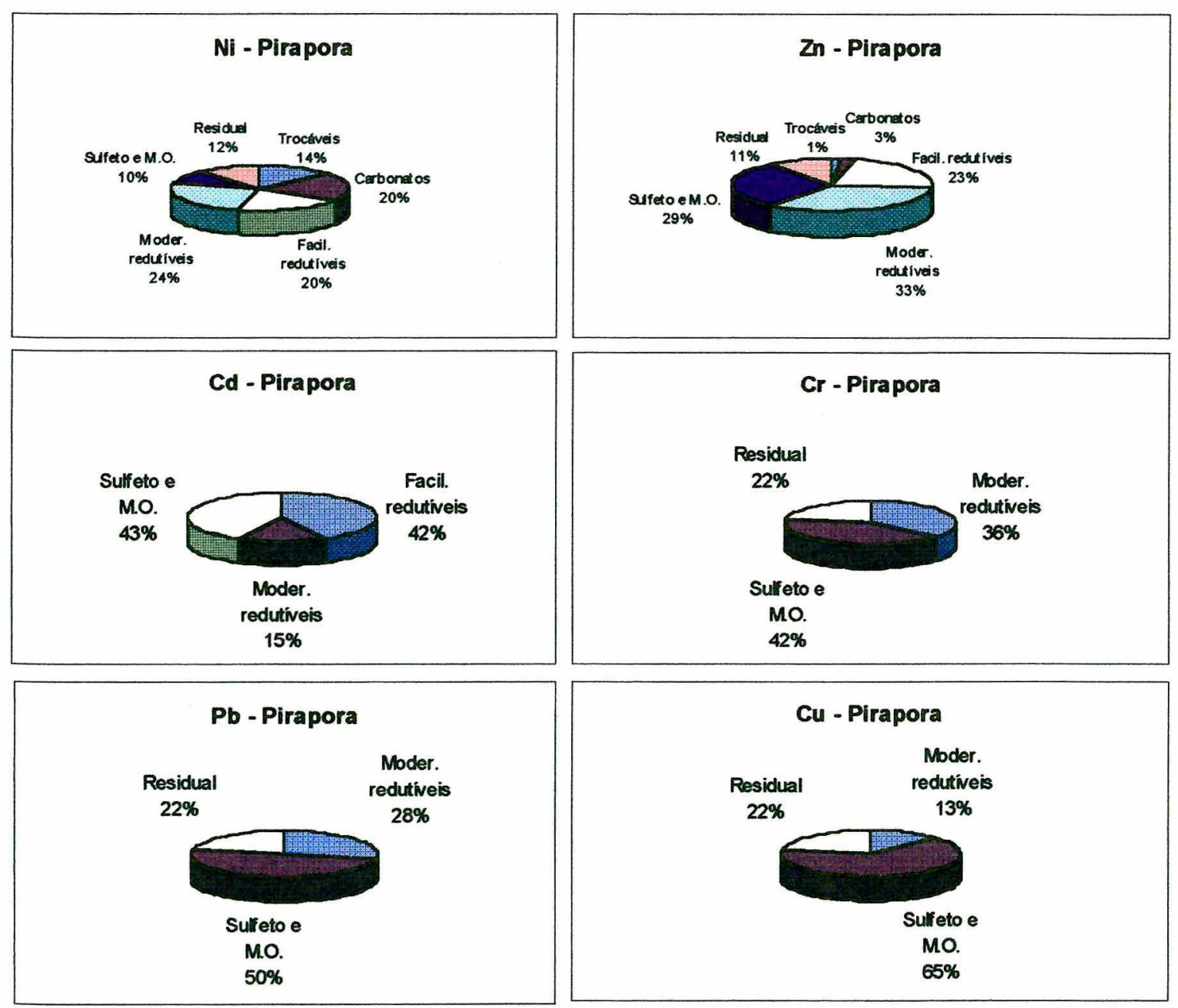

FIGURA 28: distribuição dos metais pesados nas diversas fases que compõem o sedimento de Pirapora, segundo o método de extração sequencial de Kersten e Förstner ${ }^{(36)}$.

Através dos resultados acima, pode-se observar que $\mathrm{Cu}, \mathrm{Cr}, \mathrm{Cd}$ e $\mathrm{Pb}$ não foram quantificados nas duas primeiras fases (trocáveis e ligados a carbonatos), por estarem em niveis menores que o limite de quantificação do método. No entanto, $\mathrm{Ni}$ e $\mathrm{Zn}$ aparecem nessas frações e com relação à fração trocável, esses resultados concordam significativamente com as observações de Gupta e Chen ${ }^{(173)}$, que ao estudarem sedimentos anóxidos, verificaram que a fração de metais ín-trocáveis diminuem na ordem: $\mathrm{Fe}>\mathrm{Mn}>\mathrm{Zn}>\mathrm{Ni}>\mathrm{Cr}>\mathrm{Pb}>\mathrm{Cd}>\mathrm{Cu}$. 
Kersten e Förstner ${ }^{(35,36)}$, ao estudarem o Rio Elba, próximo à baía de Hamburgo, encontraram valores menores que $0,1 \%$ para todos os metais $(\mathrm{Cr}, \mathrm{Cd}, \mathrm{Cu}, \mathrm{Pb}, \mathrm{Zn}$ e Ni) no primeiro extrato. Os resultados obtidos da amostra de Pirapora confirmam a importância da manutenção da atmosfera controlada (livre de $\mathrm{O}_{2}$ do ar) durante essas duas primeiras extrações.

Para o segundo extrato, encontraram valores menores que $0,1 \%$ para $\mathrm{Pb}$, Cu e Cd e para $\mathrm{Zn}$, Ni e $\mathrm{Cr}$ encontraram 2,4; 13,8 e 9,2; respectivamente. Para as amostras do Tietê, os valores encontrados foram de $3 \%$ para o $\mathrm{Zn}$ e $20 \%$ para o Ni. Portanto, os valores se assemelham significativamente nesses dois estudos.

O terceiro extrato (óxido facilmente redutível) teve uma significativa contribuição em Cd (42\%), Zn (33\%) e Ni (20\%). Os resultados verificados no rio Elba foram: $\mathrm{Pb}$, Cu e Cd (menores que 0,1\%); Zn (5,6\%), Ni (9,0\%) e $\operatorname{Cr}(1,5 \%)$

Com relação ao quarto extrato (óxidos moderadamente redutivel), foi verificado que os metais distribuem-se da seguinte forma : Ni (24\%), Zn (33\%), Cd (15\%), $\mathrm{Cr}(36 \%), \mathrm{Pb}(28 \%)$ e $\mathrm{Cu}(13 \%)$. há uma concordância significativa desses resultados com os obtidos para o Elba em: $\mathrm{Ni}(24,8 \%), \mathrm{Zn}(36,5 \%)$ e $\mathrm{Cr}(39 \%)$ e as maiores diferenças foram para $\mathrm{Cd}(15 \%), \mathrm{Pb}(17,7)$ e $\mathrm{Cu}(0,7 \%)$ Verifica-se uma importante contribuição na amostra de Pirapora no quinto extrato (sulfeto e matéria orgânica) dos metais: $\mathrm{Pb}(50 \%), \mathrm{Cd}(43 \%), \mathrm{Cu}(65 \%), \mathrm{Cr}(42 \%)$ e, em menor extensão, $\mathrm{Zn}(29 \%)$ e $\mathrm{Ni}(10 \%)$ Os resultados para o rio Elba foram algo discordantes: $\mathrm{Pb}(71,7 \%), \mathrm{Cd}(96,6 \%), \mathrm{Cu}(86,9 \%), \mathrm{Cr}(32,4 \%), \mathrm{Zn}(50,0 \%)$ e Ni $(32,1 \%)$. No entanto, os valores são elevados nos dois estudos. Pode-se com os resultados obtidos para Pirapora, considerar que o nivel elevado de sulfeto volátil encontrado no estudo anterior (14423 \pm 25 ppm), e ions polissulfeto têm uma participação significativa no controle destes metais para a biota aquática.

Os valores de metais residuais (ou metais ligados a minerais cristalinos litogênicos), na amostra de Pirapora foram: $\mathrm{Ni}(12 \%), \mathrm{Zn}(11 \%), \mathrm{Cr}(22 \%), \mathrm{Pb}$ (22\%) e $\mathrm{Cu}(22 \%)$ e $\mathrm{Cd}(<\mathrm{L} . \mathrm{Q}$.). Para o rio Elba, foram verificados: $\mathrm{Ni}(20,2 \%), \mathrm{Zn}$ (5,6\%), $\mathrm{Cr}(17,6 \%), \mathrm{Pb}(10,6 \%), \mathrm{Cu}(12,4 \%)$ e $\mathrm{Cd}(1 \%)$. Pode-se inferir que em 
ambos os casos, há uma menor porcentagem nessa fase quando se comparam estes resultados com os de um ambiente aquático não contaminado, como o Rio Ottawa ${ }^{(174)}$ : Ni $(87 \%), \mathrm{Zn}(87 \%), \mathrm{Pb}(69,7 \%)$ e $\mathrm{Cu}(91,3 \%)$. Isto quer dizer que tanto o Tietê quanto o Elba fazem parte de uma categoria de rios com elevada carga poluidora recentemente depositada e portanto, devem ser rigorosamente monitorados.

Com relação à amostra de Barra Bonita, os resultados encontrados pelo método de extração sequencial podem ser vistos na figura 29 : 

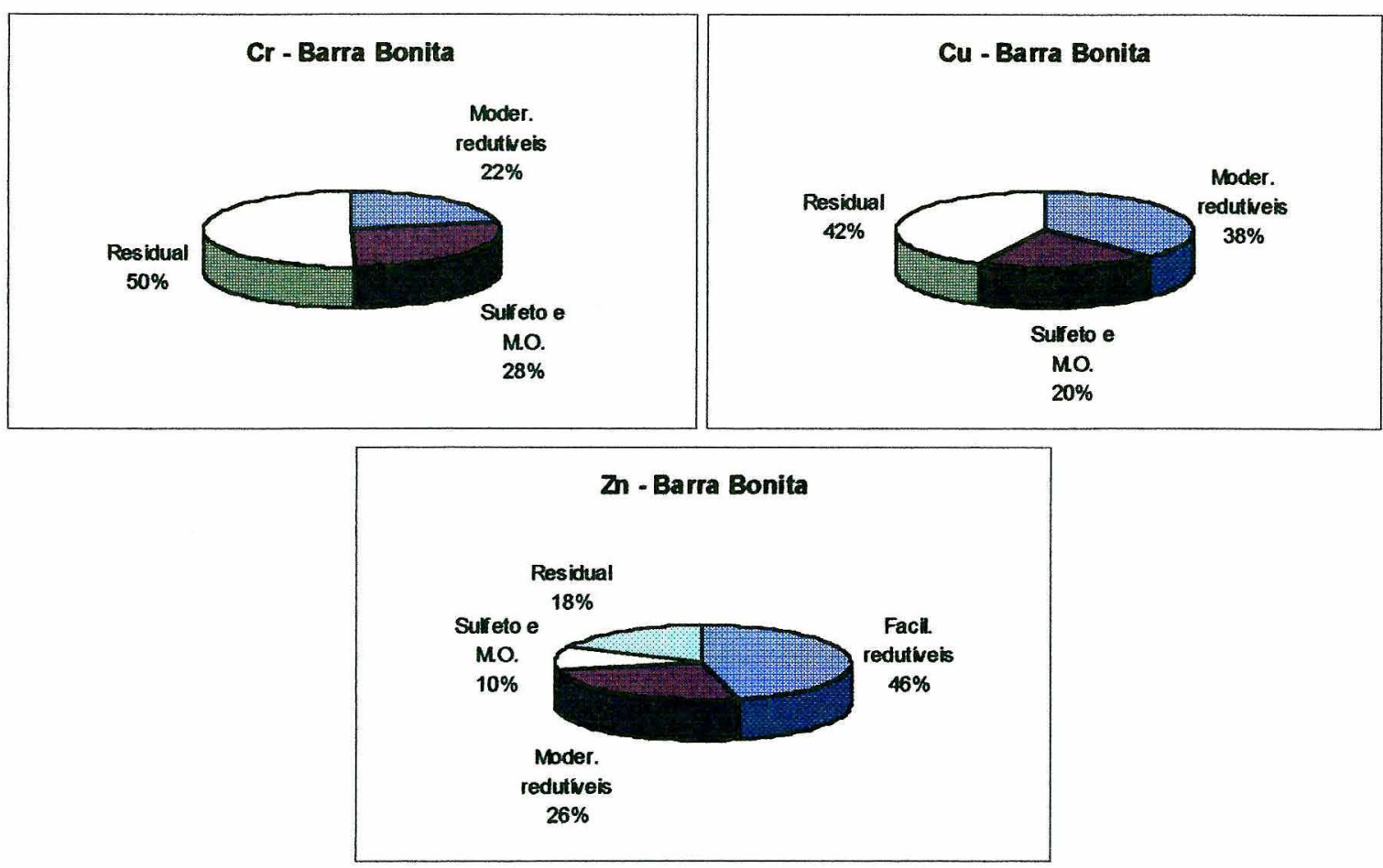

FIGURA 29: distribuição dos metais pesados nas diversas fases que compõem o sedimento da Entrada de Barra Bonita, segundo o método de extração sequencial de Kersten e Förstner ${ }^{(35,36)}$.

Através dos resultados acima, pode-se observar que $\mathrm{Pb}, \mathrm{Ni}$ e $\mathrm{Cd}$ não foram quantificados nos extratos da amostra de Barra Bonita, provavelmente pelo fato de que esses extratos apresentaram concentrações de $\mathrm{Pb}, \mathrm{Ni}$ e $\mathrm{Cd}$ inferiores ao L.Q. do método. No entanto, $\mathrm{Cr}$, $\mathrm{Cu}$ e $\mathrm{Zn}$ foram determinados sem qualquer problema nas amostras de entrada de Barra Bonita. Pode-se com isso verificar que no terceiro extrato (facilmente redutível), $\mathrm{Zn}$ apresenta um valor de $46 \%$, e os demais metais, menores que o L.Q.. Para o quarto extrato (moderadamente redutivel), foram verificados os valores de $22 \%$ para $\mathrm{Cr}$, $38 \%$ para $\mathrm{Cu}$ e $26 \%$ para $\mathrm{Zn}$, respectivamente. Com relação ao quinto e sexto extratos (metais associados a sulfetos e matéria orgânica e metais associados a cristais litogênicos cristalinos, respectivamente), cabem algumas considerações: os resultados obtidos em Pirapora e Barra Bonita foram $\mathrm{Cr}: \underline{28 \%}$ (Barra Bonita) versus $\underline{42 \%}$ (Pirapora); $\mathrm{Cu}$ : 
20\% (Barra Bonita) versus $\underline{65 \%}$ Pirapora e Zn: 10\% (Barra Bonita) versus $\underline{29 \%}$ (Pirapora). O ambiente de Pirapora é controlado pela concentração de sulfetos voláteis e polissulfetos presentes no sedimento e Barra Bonita apresenta uma outra distribuição para os metais, pois sua concentração de sulfeto volátil é cerca de 140 vezes menor que a encontrada em Pirapora. Portanto, confirmam-se os resultados observados até $O$ presente, de não haverem evidências de contaminação de Barra Bonita proveniente de Pirapora. A comparação entre os extratos da fração residual esclarece um pouco mais a situação dessas duas amostras. Os resultados foram $\mathrm{Cr}: 50 \%$ (Barra Bonita) versus 22\% (Pirapora); $\mathrm{Cu}$ : 42\% (Barra Bonita) versus 22\% (Pirapora) e Zn 18\% (Barra Bonita) versus 11\% (Pirapora). Com isso, confirma-se novamente os argumentos até aqui sustentados, pois Barra Bonita apresenta niveis metais associados a fração de minerais litogênicos e cristalinos significativamente superiores aos de Pirapora, corroborando assim com os resultados de Esteves, há 15 anos atrás e com os resultados de folhelho médio, que indicam que Barra Bonita não está contaminada por estes metais.

Segundo Kersten e Förstner ${ }^{(16)}$, os metais associados a esta fase (litogênica) não participam dos processos ambientais recentes, não sendo portanto, biodisponíveis ${ }^{(46)}$.

Com relação à utilização do método de extração sequencial, deve-se frisar que apesar deste procedimento ser considerado como de ampla aceitação nos estudos relativos a sedimentos contaminados, algumas críticas podem ser apontadas com relação à sua utilização: $A$ escolha dos reagentes é um ponto que deve ser frisado nesta consideração. Além dos problemas de precipitação verificados durante a conservação dos extratos, há ainda problemas conceituais de química, quando p.e., sugere-se a preparação de cloridrato de hidroxilamina (um redutor) em meio de $\mathrm{HNO}_{3}$ (um oxidante), ou de $\mathrm{NH}_{4} \mathrm{OAc}$ em meio de $\mathrm{HNO}_{3}$ e ainda os problemas de matriz causados pelo meio sugerido para a quarta etapa de extração (tampão oxalato, $\mathrm{NH}_{4} \mathrm{C}_{2} \mathrm{O}_{4} / \mathrm{H}_{2} \mathrm{C}_{2} \mathrm{O}_{4}$ ). Outra limitação no uso do método 
de Kersten e Förstner está no fato de que é extremamente tedioso trabalhar-se tanto tempo em condições controladas. Somado a isso, deve-se considerar que os tempos de sedimentação das amostras, após as etapas de extração são muito longos, em alguns caso chegando a 3 dias, o que inviabiliza a aplicação deste método para uma quantidade significativa de amostras. Para se ter uma idéia do tempo de análise requerido, conseguiu-se concluir um ciclo de extrações para

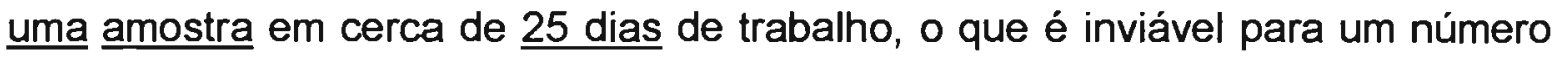
significativo de amostras. Já o método de avaliação de metais potencialmente biodisponiveis ( $\mathrm{HCl} 0,1 \mathrm{M}$ ) apresenta uma série de vantagens quando comparado ao método de extração sequencial: (1) pode-se trabalhar com um número muito maior de amostras simultaneamente; (2) requer algumas horas para ser concluído, (3) apresenta uma maior reprodutibilidade de resultados e (4); oferece menores riscos de contaminação às amostras.

\section{8. análise granulométrica}

A análise granulométrica dos sedimentos foram realizadas pelo procedimento recomendado por Ackermann et al. ${ }^{(111)}$ ao estudarem diversos sedimentos contaminados no estuário de Elba, na Alemanha.

Foram analisadas 7 amostras (as mesmas escolhidas para a análise de sulfeto ácido volátil) e os resultados estão apresentados na tabela 20:

TABELA 20: Resultados da análise granulométrica de sete amostras de sedimentos do Rio Tietê:

\begin{tabular}{|c|c|c|c|}
\hline Estaçüo & $<63 \mu \mathrm{mm}$ & $<2(1) \mu \mathrm{m}$ & Umidade(\%) \\
\hline casa do Luis (Pirapora) & $52 \pm 3$ & $36 \pm 3$ & 75,5 \\
\hline Rasgäo (Pirapora) & $40 \pm 3$ & $23 \pm 1,7$ & 63,7 \\
\hline Tecelagem (Pirapora) & $69 \pm 4$ & $8 \pm 0,5$ & 48,9 \\
\hline Ponte do rioTiete-Capivari & $39 \pm 3$ & $47 \pm 3$ & 50,4 \\
\hline Entrada de Barra Bonita & $24 \pm 2$ & $4 \pm 0,2$ & 36,3 \\
\hline Jusante de Barra Bonita & $35 \pm 3$ & $2 \pm 0,2$ & $\mathbf{2 7 , 5}$ \\
\hline Ilha de Barra Bonita & $9 \pm 0,3$ & $1 \pm 0,2$ & 11,8 \\
\hline
\end{tabular}

* resultados de triplicatas de determinações 
As amostras de correspondentes ao trecho próximo à região metropolitana de São Paulo apresentam uma granulometria com significativa distribuição nas frações < $63 \mu \mathrm{m}$ (silte grosso e silte médio) e $<20 \mu \mathrm{m}$ (silte fino e argila). Há duas diferentes contribuições para esta granulometria: a própria formação natural de argilominerais, predominantes neste trecho de estudo, além da matéria orgânica em avançado estágio de degradação, através dos mecanismos de catabolismo, cominuição/fragmentação e lixiviação ${ }^{(119)}$. Vale ressaltar que a matéria orgânica, bem como os óxidos hidratados de ferro e ainda os óxidos fácilmente redutiveis de manganês, distribuem-se nas frações $<20 \mu \mathrm{m}$, dai a forte interação desses materiais com os metais traço ${ }^{(16)}$.

Conforme foi ressaltado acima, a presença de matéria orgânica nas frações mais finas é um forte indicativo de estar ocorrendo uma significativa deposição de materiais provenientes de efluentes municipais, que ainda estão em processo de mineralização e portanto, atuantes tambem no controle do aporte e redistribuição dos metais. Tal fenômeno pode ser observado nas amostras correspondentes a casa do Luis e Rasgão, dois reservatórios que atuam como ambientes típicos de deposição de materiais. Isso vem a explicar os resultados observados para os metais pesados nas fraçōes 3,4 e 5 ( oxidos de manganês, óxidos de ferro amorfo e sulfeto e matéria orgânica, respectivamente). Nesse sentido, os sedimentos são intensamente atuantes nos processos sólidos/solução, pois uma maior área de superfície implica necessariamente em maior reatividade, e consequentemente verificam-se maiores trocas de metais com as variações de $E_{H}$ e de $\mathrm{pH}$.

Como o tipo de sedimentc diz respeito ao grau de contaminação que ele possa representar à biota aquá:ica, os sedimentos de casa do Luis e Rasgão (ambos em Pirapora), por apresentarem uma elevada fração de grãos finos, confirmam sua elevada potencialıdade de disporem metais traço à biota aquática, por conta de suas características físicas, fato este também verificado pelo método dos metais potencialmente biodisponiveis.

Com relação a amostra de Tecelagem (Pirapora), verifica-se uma 
diminuição do tamanho de grãos correspondentes à fração $<20 \mu \mathrm{m}$, devido a um menor regime de deposição de matéria orgânica, seu maior processamento, e ainda ao fato de que segundo Silva ${ }^{(131)}$, nas partes mais profundas do rio Tietê, na região de Pirapora do Bom Jesus, predominam sedimentos mais finos (argila) que incluem as camadas originais do rio, enquanto que as partículas maiores (silte, areia) estão associadas com áreas marginais. A amostra correspondente a ponte do rio Tietê- Capivari apresentou os mais elevados valores desta fração $(<20 \mu \mathrm{m})$, onde se conclue que o regime de sedimentação deste ponto se assemelha ao de Pirapora. Vale ressaltar que as amostras de casa do Luis, Rasgão, Tecelagem e ponte do rio Tietê-Capivari são muito semelhantes quanto ao aspecto externo, cor, odor, etc.

As amostras referentes à Barra Bonita apresentam um perfil completamente diferente das amostras da região de Pirapora. Através da tabela acima, pode-se observar que os resultados correspondentes à fração $<63 \mu \mathrm{m}$ de Barra Bonita são significativamente menores que os de Pirapora. Isto se explica pela formação natural dos sedimentos existentes no reservatório somado a uma menor carga poluidora lançada nesse ambiente, havendo assim uma menor contribuição de deposição da matéria orgânica. O resultado referente à amostra de margem esquerda de Barra Bonita - ilha, reflete muito bem essas considerações, pois verifica-se para esta amostra uma distribuição de tamanho de grãos de $9 \%$ para a fração $<63 \mu \mathrm{m}$ e $1 \%$ para a fração $<20 \mu \mathrm{m}$. Como o reservatório de Barra Bonita apresenta um perfil granulométrico significativamente diferente de Pirapora, podese inferir que o sedimento de Barra Bonita não participa de forma ativa na redistribuição de espécies para a coluna de água. Isto é corroborado pelos resultados obtidos no método de extração sequencial, que realça o fato dos sedimentos de entrada de Barra Bonita possuírem um elevado nivel de metais associados a frações minerais litogênicas e portanto, não biodisponíveis.

O método de desagregação por ultrassom utilizado neste estudo tem sido considerado por alguns autores como sendo impróprio para amostras de 
sedimentos, pelo fato que a energia fornecida à amostra muda irreversivelmente o tamanho dos grãos, aumentando consequentemente as frações mais finas ${ }^{(107)}$. Ackermann et al. ${ }^{(111)}$ não verificaram qualquer alteração em seus resultados nesse sentido, sendo que o método de desagregação por ultrassom é utilizado rotineiramente em programas de monitoramento de corpos d'água na Alemanha, conforme as recomendações do grupo de trabalho de sedimentos aquáticos da "Associação Alemã de Química da Água" ${ }^{r(35)}$. Para uma análise granulométrica ser realizada a contento, é fundamental que haja uma boa separação entre as partículas. Conforme já foi citado anteriormente, Wall et al. ${ }^{(115)}$ observaram que durante a separação da fração silte / argila da amostra, com técnicas de dispersantes químicos, agitação mecânica e subsequente peneiramento, quantidades consideráveis das partículas pequeninas se agregaram às maiores. Segundo o próprio Wall ${ }^{(115)}$, isto desaconselha o uso de tais procedimentos de desagregação das partículas. Com relação às amostras do Tietê, vale lembrar que Eysink et al. ${ }^{(135)}$, utilizando a técnica de peneiramento diferencial em água, recomendada por Folk ${ }^{(175)}$, dentre outros autores, que não faz uso do ultrassom, obtiveram resultados superiores aos de ultrassom para as frações $<63 \mu \mathrm{m}<20$ $\mu \mathrm{m}$, mostrando assim que o uso do ultrassom não modificou o tamanho original das partículas. Portanto, pode-se considerar que este método de desagregação pode ser utilizada de forma significativamente favorável dentro do protocolo de procedimentos adotado.

\section{9. análise textural}

A análise textural foi utilizada neste estudo, a fim de se ter uma idéia superficial dos aspectos morfológicos dos sedimentos e possivelmente detectar a contaminação dessas amostras, conforme sugerem alguns importantes trabalhos desenvolvidos neste campo ${ }^{(15,117)}$. Foram estudadas 3 amostras: casa do Luís (Pirapora), Rasgão (Pirapora) e entrada de Barra Bonita. As figuras abaixo apresentam os resultados obtidos: 

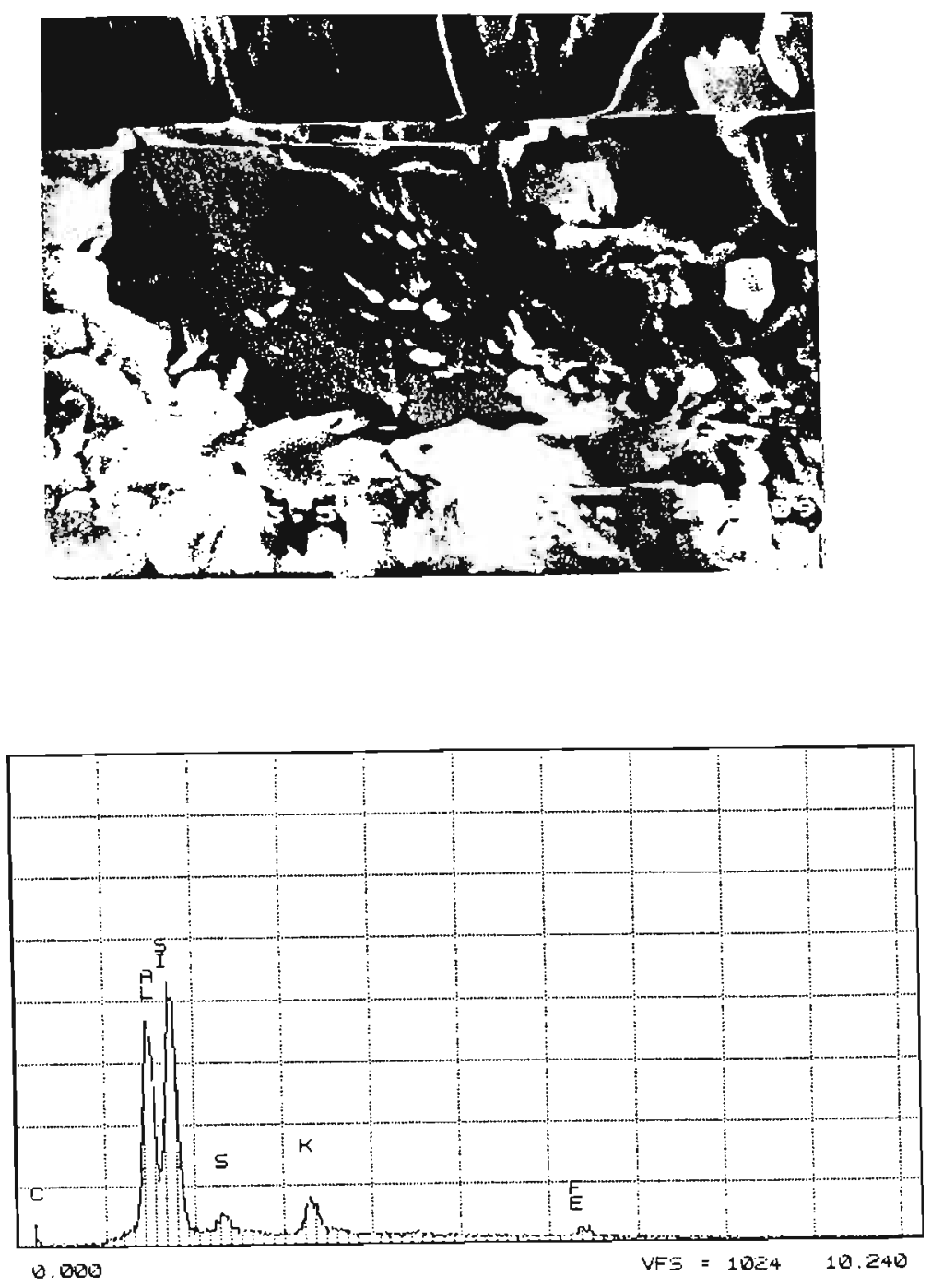

FIGURA 30: imagem ao microscópio eletrônico de varredura (A) textura geral do sedimento de casa do Luís (testemunho de $16-18 \mathrm{~cm}$ de profundidade); (B) espectro obtido por EDX, indicando as associações químicas.

A micrografia acima, em conjunto com o espectro de EDX sugerem a formação de mica, que é a forma precursora dos argilominerais, para o testemunho de 16 a $18 \mathrm{~cm}$ de profundidade. Estas observações concordam com os resultados de granulometria, confirmando assim haver uma significativa 
contribuição de argilominerais aos sedimentos de Pirapora, nesta amostra. Alguns indícios de contaminação dos sedimentos de Pirapora podem ser observados a seguir (figura 31 ):
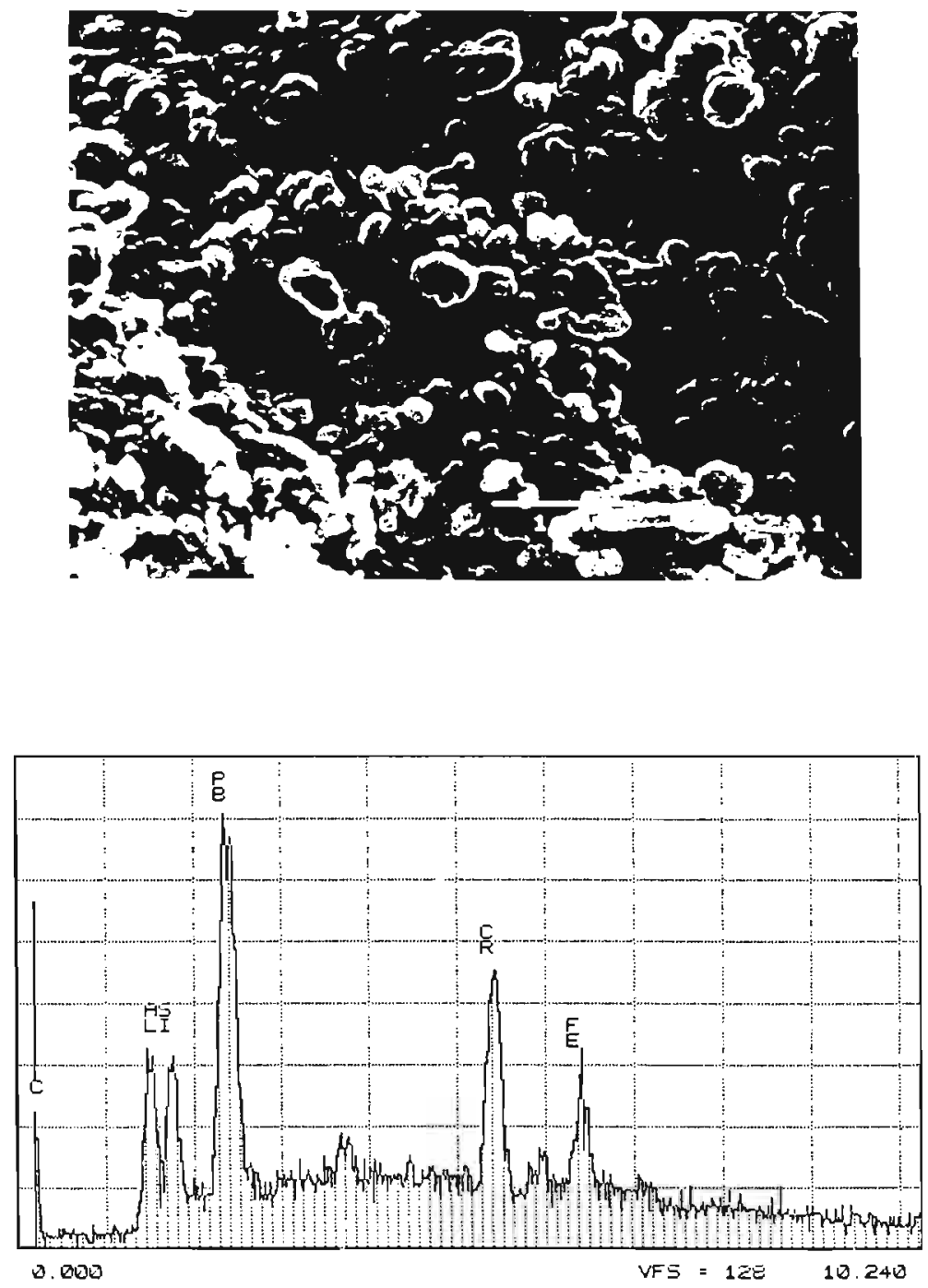

FIGURA 31: imagem ao microscópio eletrônico de varredura (A) textura geral do sedimento de casa do Luís (10-12 cm de profundidade); (B) espectro obtido por EDX, indicando as associações químicas. 
A figura 31 sugere uma formação de glóbulos de argila com contornos de átomos de ferro, neste testemunho (entre 10 a $12 \mathrm{~cm}$ de profundidade). Há ainda fortes indícios de contaminação deste sedimento por $\mathrm{Pb}$ e $\mathrm{Cr}$, detectados no EDX.

Outros importantes resultados caracterizam o sedimento de casa do Luís. A figura 32 traz os espectros de EDX desta amostra, em um testemunho de 2 a $4 \mathrm{~cm}$ de profundidade.

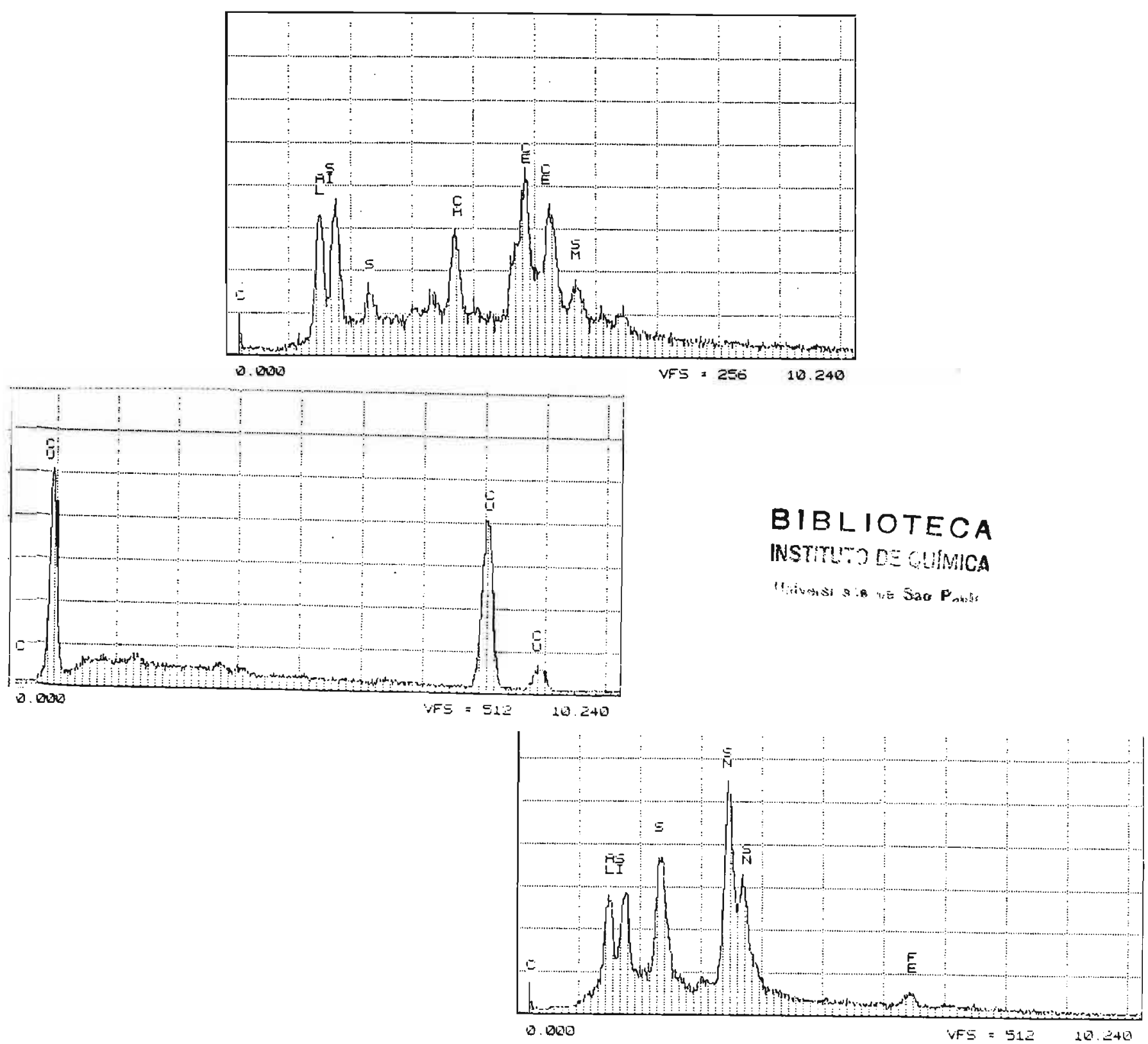

FIGURA 32: espectros obtidos por EDX, para amostra de casa do Luís (Pirapora), numa secção de 2-4 cm de profundidade. 
Nota-se nesta secção do sedimento, através dos espectros de EDX formações de argilominerais, gipso $\left(\mathrm{CaSO}_{4}\right)$ e ainda indícios de contaminação de metais pesados, tais como $\mathrm{Sn}$ e $\mathrm{Cu}$. Pode-se ainda verificar a presença de terras raras, como $\mathrm{Ce}$ e Sm. A figura abaixo (fig.33) representa os espectros obtidos por EDX, em um testemunho de 10 a $12 \mathrm{~cm}$, do sedimento de casa do Luís (Pirapora).
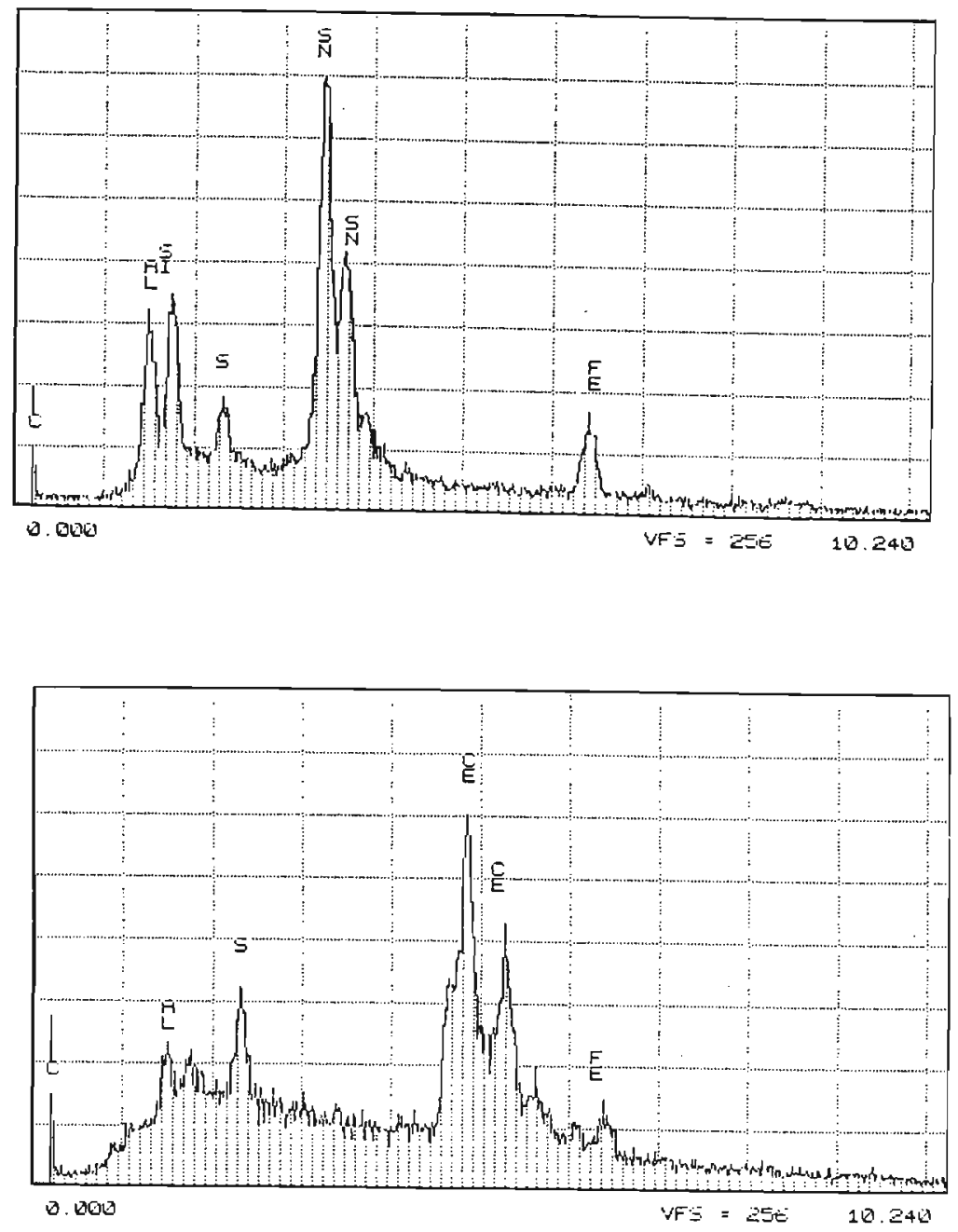

FIGURA 33: espectros obtidos por EDX, para amostra de casa do Luis (Pirapora), numa secção de $10-12 \mathrm{~cm}$ de profundidade. 
Os espectros apresentados na página anterior sugerem formações de argilominerais, além da presença de elementos pouco comuns, tais como $\mathrm{Ce} \mathrm{e}$ Sn. Outros importantes resultados estão na figura 34 :
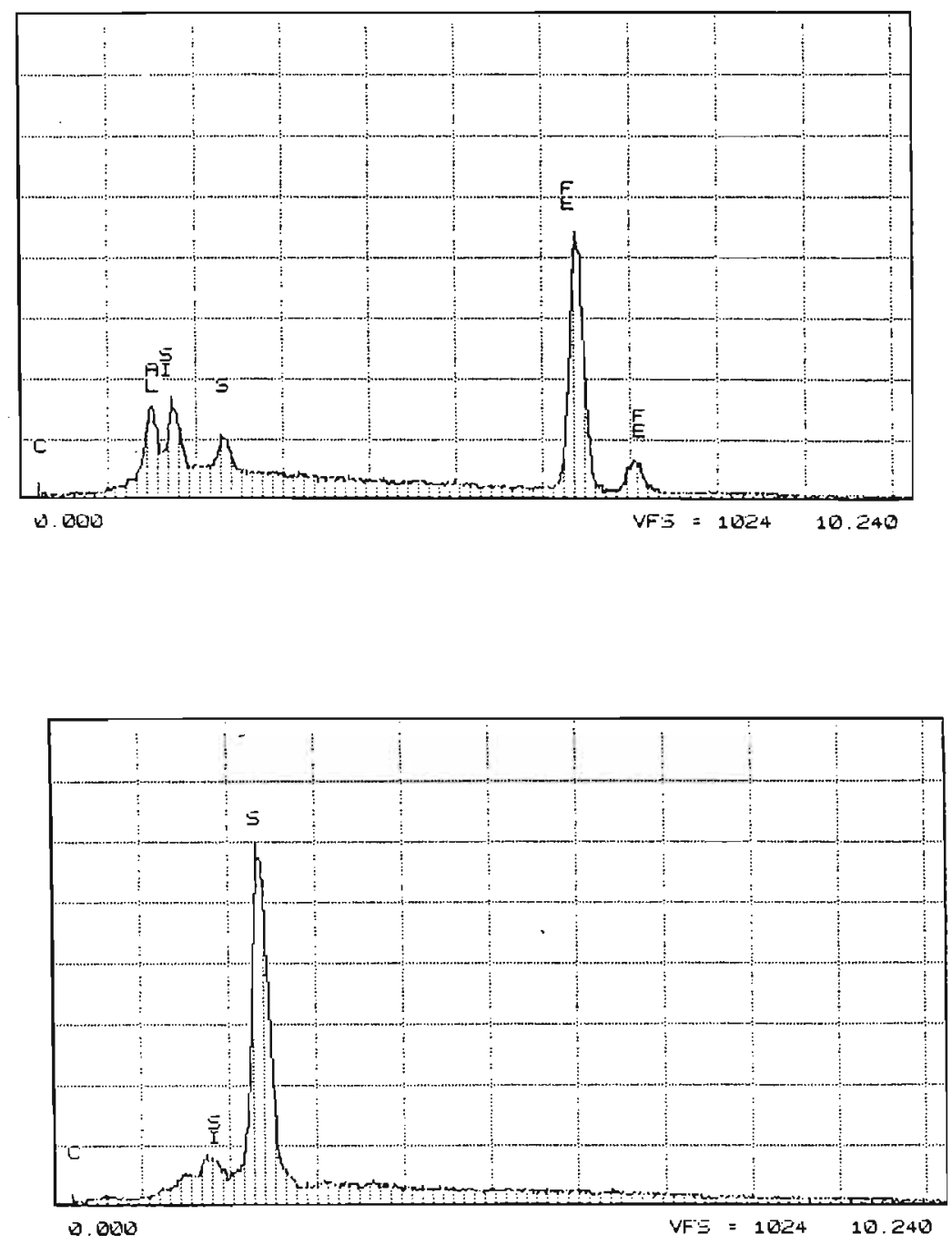

FIGURA 34: espectros obtidos por EDX, para a amostra de casa do Luís (Pirapora), numa secção de $16-18 \mathrm{~cm}$ de profundidade. 
Os espectros acima concordam com os anteriores, e também sugerem formações de argilominerais, além de uma presença marcante de matéria orgânica, pois, apesar de não ter sido apresentada neste estudo, a micrografia correspondente à figura 32-b, revelou a presença de vermes, sugerindo assim haver uma intensa atividade diagenética neste ambiente. A amostra de Rasgão, assim como a de casa do Luís, apresentou níveis significativos de metais e de matéria orgânica. A figura abaixo ilustra os resultados observados para este ponto amostral:
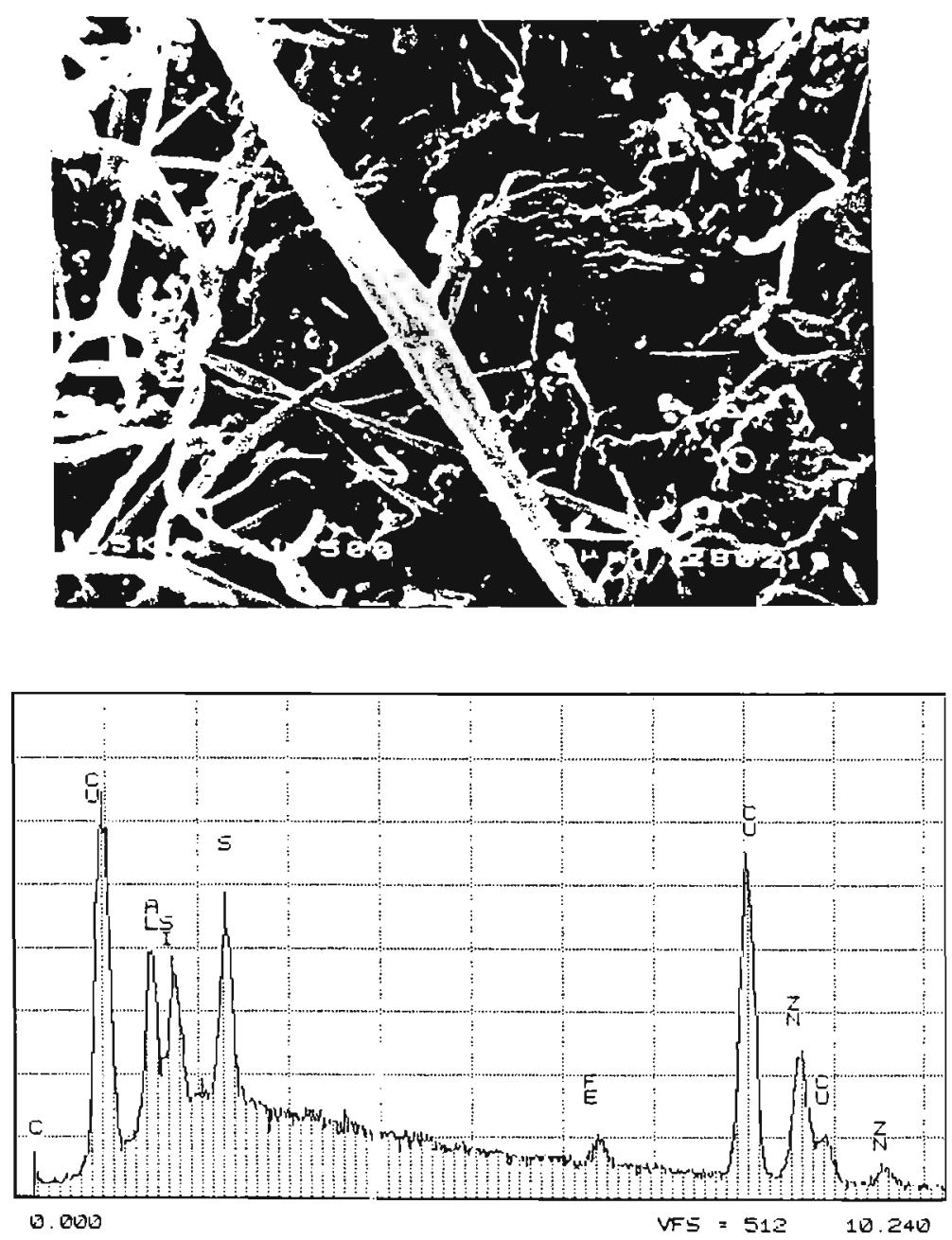

FIGURA 35: imagem ao microscópio eletrônico de varredura (A) textura geral do sedimento de Rasgão (2-4 cm de profundidade); (B) espectro obtido por EDX, indicando as associações químicas. 
A micrografia em conjunto com o espectro de EDX, sugerem a formação de argilominerais e ainda indícios de contaminação de metais como $\mathrm{Cu}$ e $\mathrm{Zn}$ nesta seç̧ão do sedimento de Rasgão $(2-4 \mathrm{~cm})$. A figura 36 também sugere formações de argilominerais:
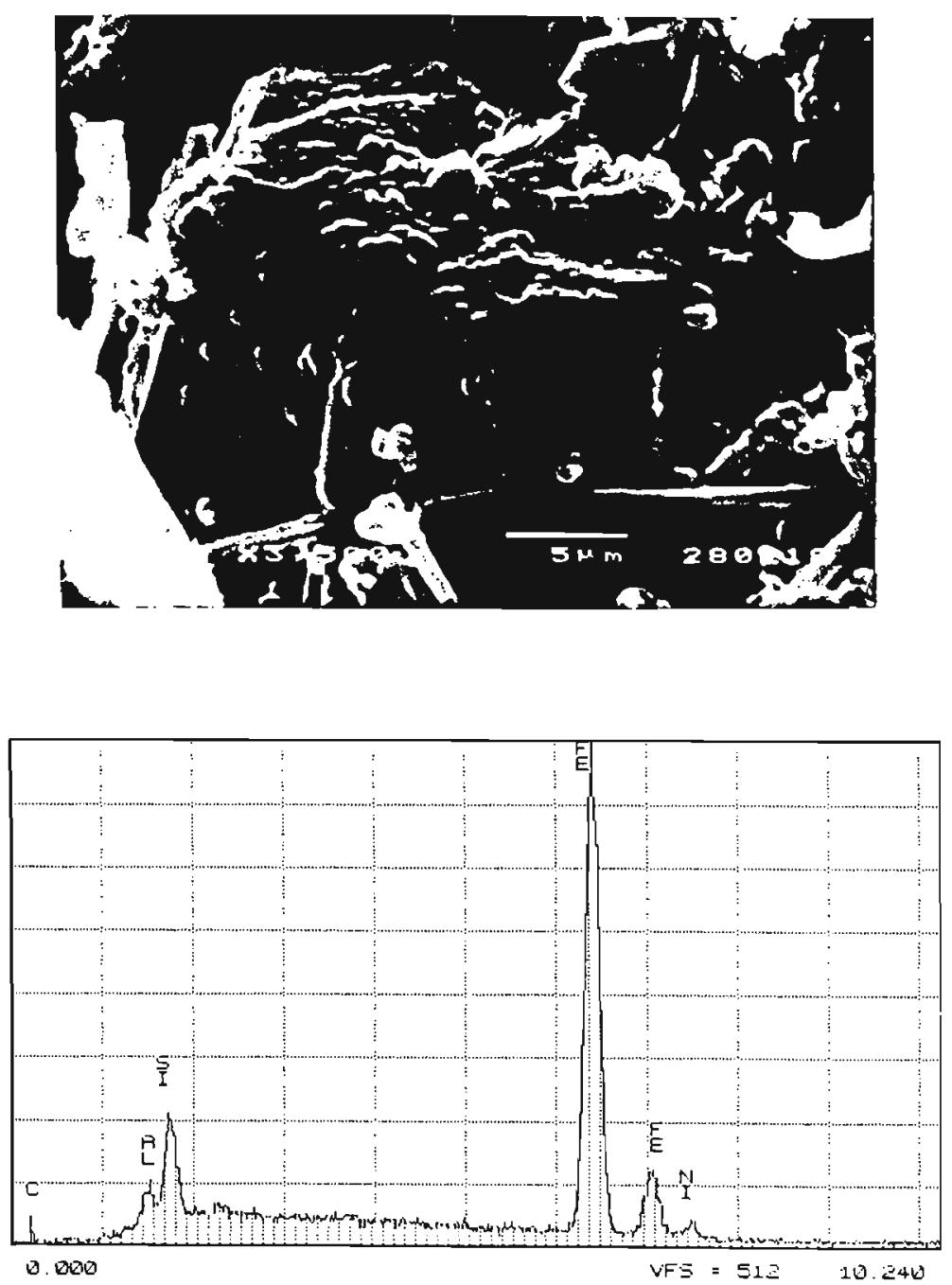

FIGURA 36: imagem ao microscópio eletrônico de varredura (A) textura geral do sedimento de Rasgão (2-4 cm de profundidade); (B) espectro obtido por EDX, indicando as associações químicas. 
Nota-se nesta análise textural, além da caracterização dos argilominerais, uma intensidade significativa do pico do ferro. A figura abaixo ilustra outros espectros de EDX obtidos para esta amostra:
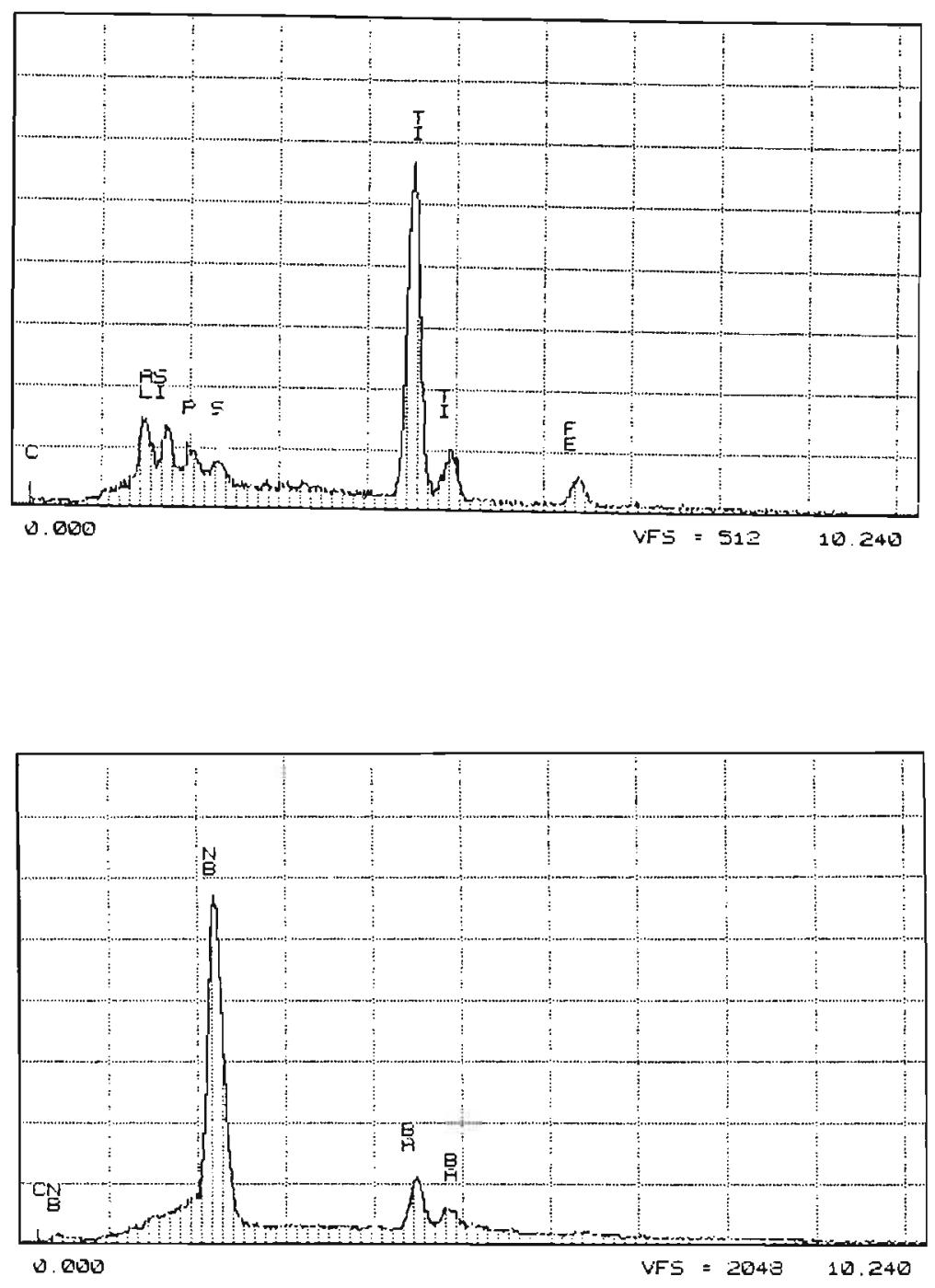

FIGURA 37: espectros obtido por EDX, para amostra de Rasgão, numa secção de 2 a $4 \mathrm{~cm}$ de profundidade 

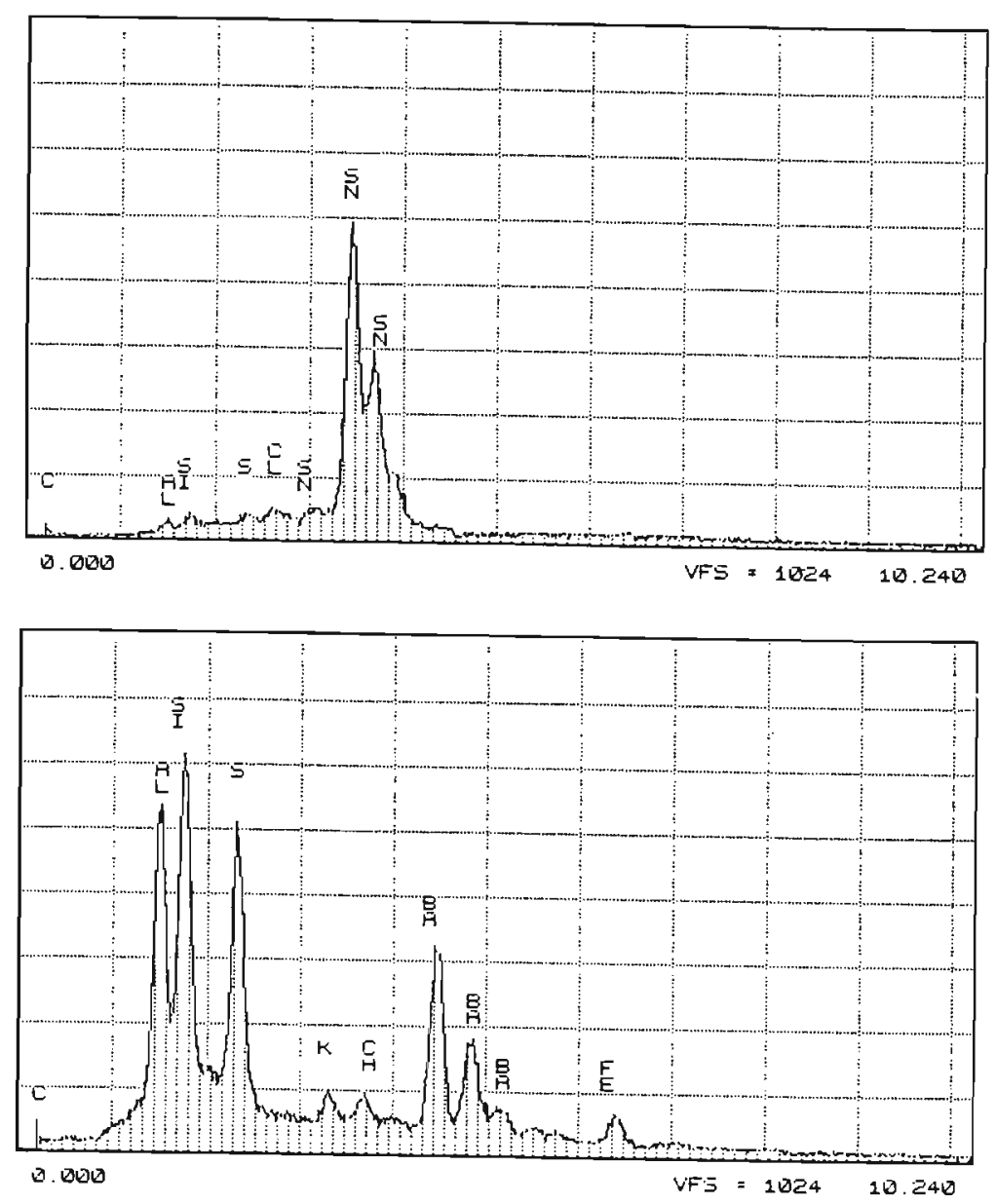

CONT.FIGURA 37. espectros obtidos por EDX,para amostra de Rasgão numa seção de 2 a $4 \mathrm{~cm}$ de profundidade.

Curiosamente, pode-se sugerir nesta secção do sedimento a presença de quartzo (baseando-se nos espectros de Barra Bonita, que serão mostrados a seguir), argilominerais, nióbio, estanho, e ainda a presença de outros minerais como barita $\left(\mathrm{BaSO}_{4}\right)$ e gipsita $\left(\mathrm{CaSO}_{4} \cdot 2 \mathrm{H}_{2} \mathrm{O}\right)$. Uma quantidade significativa de matéria orgânica pode ser observada pela imagem do MEV, sugerindo assim haver uma intensa atividade diagênica. Tal presença foi também constatada em casa do Luís, conforme foi abordado anteriormente. Pode-se notar também indícios de contaminação por elementos raros (como p.e. $\mathrm{Nb}$ ) e ainda metais como Sn.

As análises texturais de Barra Bonita estão representadas a seguir (fig. 38): 


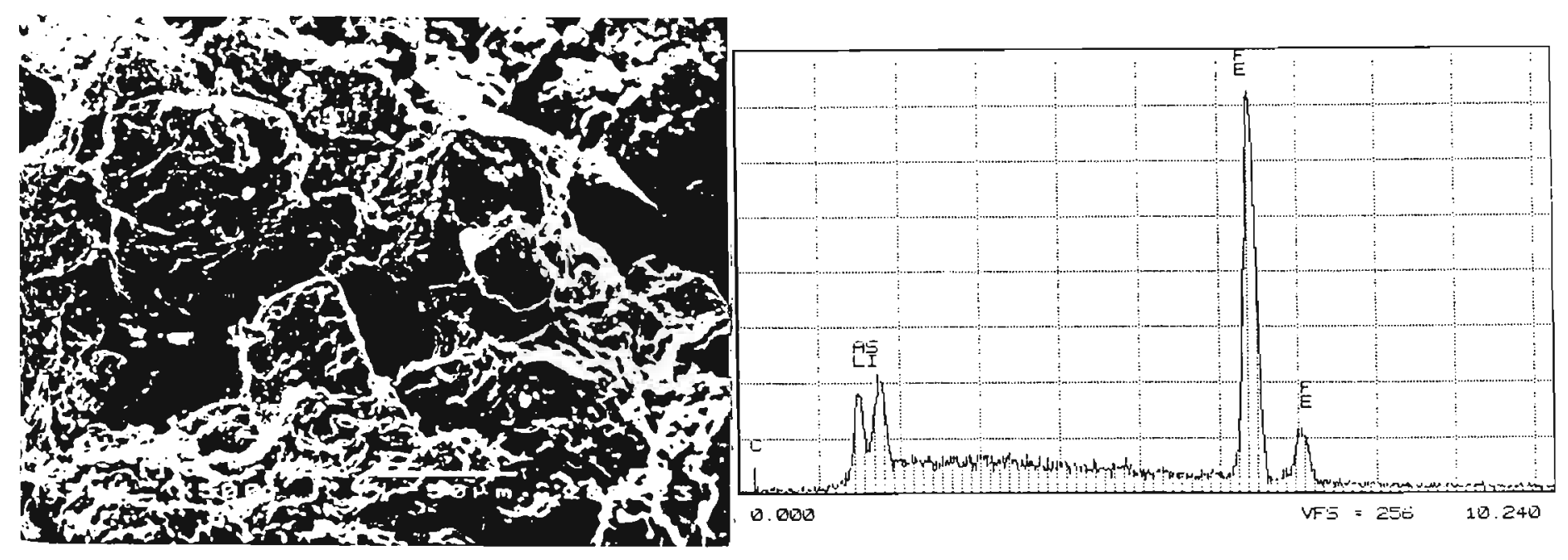

FIGURA 38: imagem ao microscópio eletrônico de varredura (A) textura geral do sedimento de entrada de Barra Bonita; (B) espectro obtido por EDX, indicando as associações químicas.

A imagem ao MEV e o seu respectivo espectro de EDX sugerem formações de grãos de quartzo. Tal consideração pode ser confirmada na figura 39 abaixo:

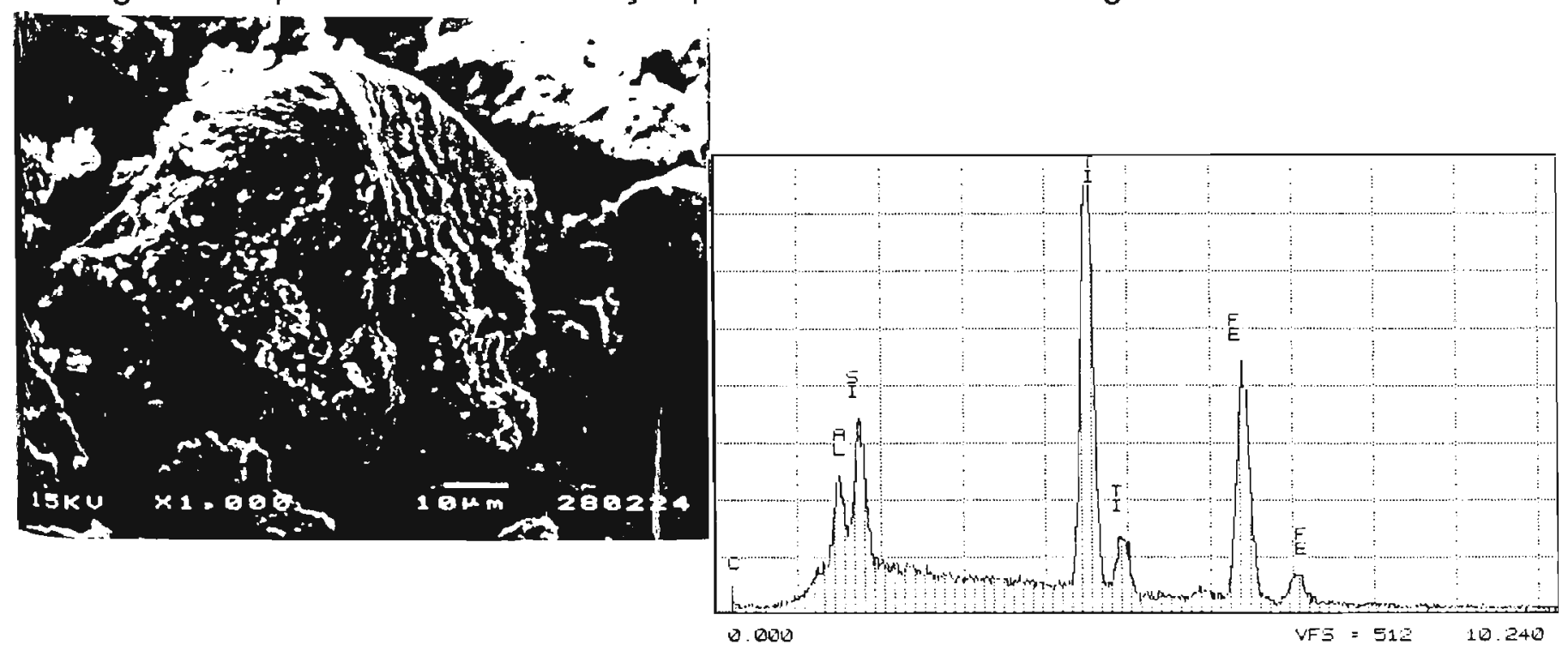

FIGURA 39: imagem ao microscópio eletrônico de varredura (A) textura detalhada do sedimento de entrada de Barra Bonita; (B) espectro obtido por EDX, indicando as associações químicas. 
Em nenhuma das análises texturais realizadas na amostra de Barra Bonita foi constatada as formações de mica e muito menos de argilominerais, corroborando os resultados da análise granulométrica para este ponto amostral. A figura 40 mostra mais alguns espectros de EDX obtidos para a amostra de Barra Bonita:
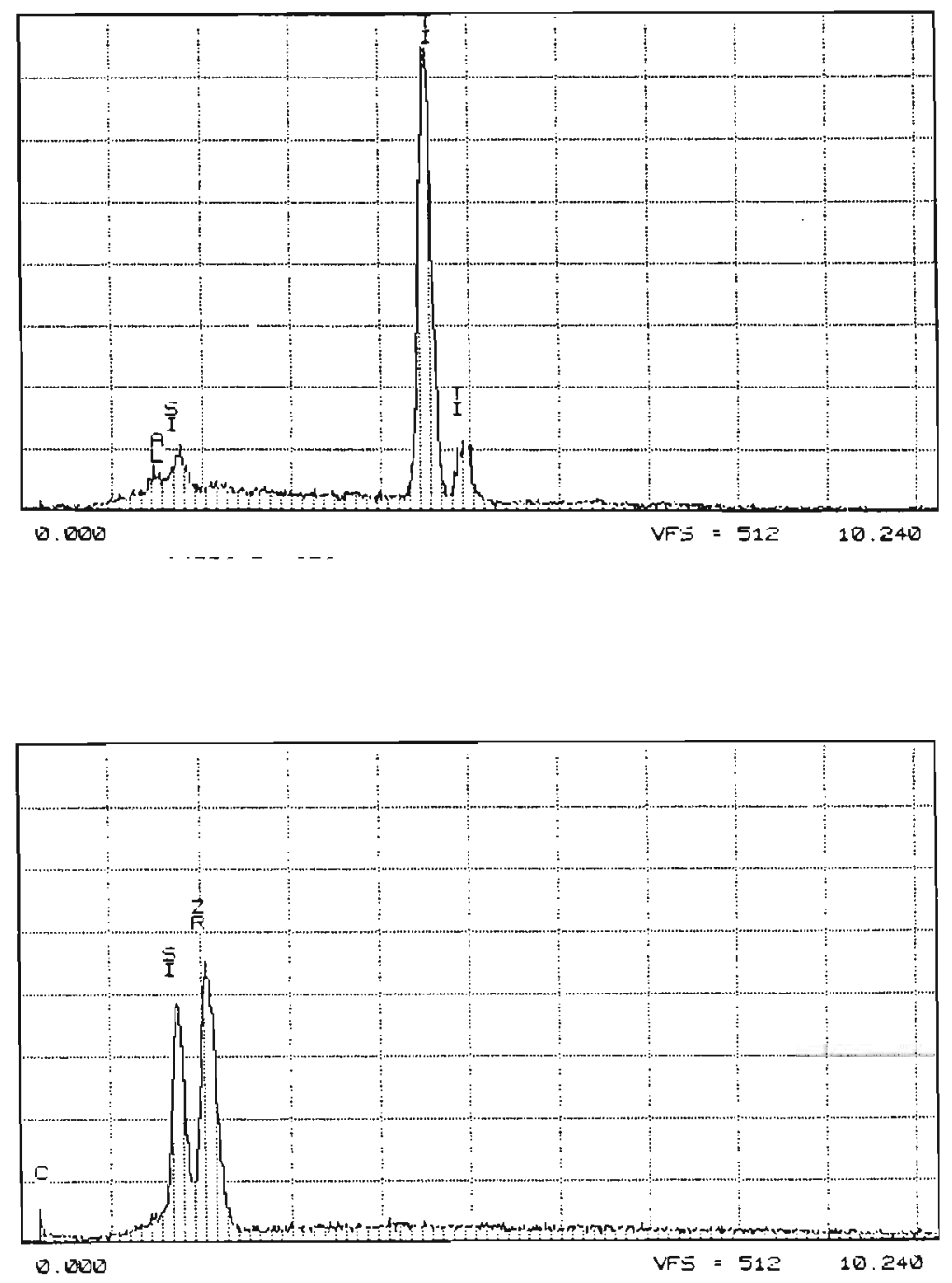

FIGURA 40: espectros de EDX para as amostras de entrada de Barra Bonita. 
As figuras mostradas acima sugerem a presença de formações minerais não encontrados até então, tais como rutilo $\left(\mathrm{TiO}_{2}\right)$ e $\mathrm{Zircão}\left(\mathrm{ZrSiO}_{4}\right)$, que acompanham os grãos de quartzo. Os resultados da análise textural observados para amostra de entrada de Barra Bonita possibilitam inferir que não há contaminação por metais pesados, concordando com a determinação realizada por absorção atômica para este ponto amostral e com os resultados de Esteves et al. ${ }^{(170)}$

Através dos resultados obtidos pela análise de MEV dos sedimentos do Tietê, pode-se considerar que esta técnica permite realizar uma minuciosa avaliação dos sedimentos sobre o aspecto textural, podendo ser, assim como a análise granulométrica, utilizada de forma significativamente favorável dentro do protocolo de procedimentos adotado.

A fim de se conhecer a extensão de contaminação proveniente de fontes de matéria orgânica ao Tietê devem ser determinados os níveis de carbono presentes no sedimento, como será visto a seguir.

\subsection{0. análise de carbono total}

A tabela abaixo ilustra os resultados obtidos para carbono total, carbono inorgânico, carbono orgânico e matéria orgânica. Nesta etapa da discussão, torna-se extremamente oportuno explanar comparativamente estes resultados aos de potencial redox e de sulfeto ácido volátil.

TABELA 21: Resultados de carbono, matéria orgânica, $E_{H}$ e SAV para algumas amostras selecionadas do Rio Tietê.

\begin{tabular}{|c|c|c|c|c|c|c|}
\hline Amostro & $\begin{array}{c}C \\
\text { torful } \\
(y)=4\end{array}$ & $\begin{array}{c}C^{\circ} \\
\text { inorgânico } \\
(1 \%(1))^{*}\end{array}$ & $\begin{array}{c}c \\
\text { orginicos) } \\
(1 / 1 / 1)^{*}\end{array}$ & $\begin{array}{l}\text { matéria } \\
\text { orgânicu } \\
(4))^{*-*}\end{array}$ & $\begin{array}{c}E_{H I} \\
(m l)\end{array}$ & $\begin{array}{c}\$ 4 V \\
(\mu m w l \\
g-l)\end{array}$ \\
\hline Pirapora & 2,72 & 0,40 & 2,32 & 3,94 & -293 & 450,0 \\
\hline Rasgão & $3, \mathbf{2 2}$ & 0,72 & 2,50 & 4,25 & -220 & 19,8 \\
\hline Tecelagem & 2,10 & 0,87 & 1,23 & 2,09 & -207 & 19,2 \\
\hline R.Capivari & 3,10 & 1,96 & 1,14 & 1,94 & -162 & 4,1 \\
\hline ent.B.Bonita & 0,90 & 0,18 & 0,72 & 1,22 & -242 & 3,2 \\
\hline jus.B.Bonita & 0,63 & 0,54 & 0,09 & 0,15 & -193 & 0,11 \\
\hline ilha B.Bonita. & 0,36 & $\mathbf{0 , 1 0}$ & 0,26 & 0,44 & +168 & n.d. \\
\hline
\end{tabular}


A diminuição dos valores de carbono orgânico encontrados nos sedimentos indicam um elevado consumo da matéria orgânica ao longo do trecho de estudo. Pode-se observar através da tabela 20 que o valor encontrado em casa do Luís (2,32\% de carbono) diminue significativamente na estaçāo amostral de Barra Bonita ( $0,72 \%$ de carbono), indicando assim estar havendo um elevado nivel de depuração. Os resultados obtidos indicam que a maior parte do carbono orgânico determinado nas amostras do Tietê é de origem alóctone, ou seja, gerado na bacia de drenagem. Desde Pirapora até a entrada do reservatório de Barra Bonita, trecho que prevalece o regime anóxido e sulfídrico, é de se esperar que haja um significativo processamento da matéria orgânica, através da degradação anaeróbica. Com isso, tem-se uma ausência de produtividade primária neste trecho, pois a própria matéria orgânica faz o papel de aceptor de elétrons na ausência do $\mathrm{O}_{2}$ do ar. Daí os elevados níveis de sulfetos voláteis verificados neste estudo.

À guisa de comparação com rios de outros ambientes impactados, como alguns rios da Europa, pode-se verificar por exemplo, em Rasgão ( ponto amostral cuja concentração de carbono orgânico é mais elevada), o valor encontrado foi de 2,50\%; enquanto que na Espanha, os valores foram de $5,7 \%$ (Rio Besos) $^{(10)}$ e de $(5,1 \%)$ no Rio Pisuerga ${ }^{(174)}$. No entanto, deve se levar em consideração as diferentes e importantes características climáticas. Em ambientes tropicais (temperaturas elevadas), o consumo de matéria orgânica é muito mais rápido que em ambientes temperados, como os da Europa (temperaturas mais baixas), e a cinética de degradação da matéria orgânica é estritamente dependente da temperatura. Portanto, pode-se esperar realmente valores menores de carbono para o Tietê. Além disso, a presença de decompositores nas condiçōes redox verificadas favorecem a conversão da matéria orgânica a metano e $\mathrm{H}_{2} \mathrm{~S}$ reduzindo-se em cerca de $60 \%$ o conteúdo de sólidos.

O ponto amostral de casa do Luís (Pirapora) apresentou um valor de matéria orgânica $(3,94 \%)$ comparável ao de Rasgão $(4,25 \%)$, o que sugere um 
mecanismo semelhante de depuração nestes dois pontos, embora os niveis de sulfetos voláteis sejam completamente diferentes ( $450 \mu \mathrm{mol} / \mathrm{g}$ em casa do Luis e $19,8 \mu \mathrm{mol} / \mathrm{g}$ em Rasgão, respectivamente). No caso de Tecelagem, verifica-se uma diminuição do valor de matéria orgânica para 2,09\%, o que sugere um intenso processamento desse material. Embora seja verificada essa diminuição percentual da matéria orgânica, os niveis de sulfeto destas duas amostras se mantém muito próximos: Rasgão (19,8 $\mu \mathrm{mol} / \mathrm{g}$ e Tecelagem19,2 $\mu \mathrm{mol} / \mathrm{g}$, respectivamente).

O valor de matéria orgânica encontrado para o ponto amostral de rio TietêCapivari $(1,94 \%)$ se assemelha ao de Tecelagem $(2,09 \%)$, mas novamente os sulfetos voláteis não acompanham esta regra $(4,1 \mu \mathrm{mol} / \mathrm{g})$. Em entrada de Barra Bonita verifica-se um valor significativamente menor de matéria orgânica $(1,22 \%)$ e de sulfetos $(3,2 \mu \mathrm{mol} / \mathrm{g})$, valores que embora sejam elevados, são significativamente menores que os observados nos pontos amostrais de Pirapora. Os valores verificados no reservatório de Barra Bonita devem estar correlacionados com a produtividade primária deste reservatório, pois este ambiente é classificado como pós-óxido e não sulfídrico. Pode-se portanto inferir que a matéria orgânica presente no reservatório de Barra Bonita é em boa parte de origem autóctone, ou seja, gerada no próprio ecossistema. No entanto, devese levar em consideração a possivel contribuição do rio Piracicaba e ainda do lançamento de efluentes de indústria de açúcar e álcool presentes na região(137).

Assim como foi verificado para os valores de SAV, o $E_{H}$ não apresentou qualquer correlação com a matéria orgânica. Entretanto, verifica-se que a matéria orgânica está mais presente nos sedimentos mais finos, corroborando com os resultados de extração sequenciłal, especificamente à fração sulfetos e matéria orgânica, e com os resultados de metais potencialmente biodisponiveis, sugerindo-se assim que a mesına reatividade da matéria orgânica pode ser esperada também para os metais traço. Foi verificado na amostra de Pirapora que os metais $(\mathrm{Pb}, \mathrm{Cu}, \mathrm{Cd}, \mathrm{Cr}$ e $\mathrm{Zr}$ ) apresentaram uma representativa associação com esta fração do sedimento. 
A determinação de carbono orgânico e consequentemente de matéria orgânica permitiu inferir considerações referentes ao nível de sua degradação e ainda estabelecer uma simples e importante comparação com os resultados de metais. A fração orgânica é tida como enriquecedora de metais traço ${ }^{(123)}$. A seguir, será abordado o isolamento e a caracterização das substâncias húmicas (ácido húmico) a fim de se estimar a presença desses importantes quelantes naturais nos sedimentos do Tietê.

\subsection{1. análise dos ácidos húmicos}

Os ácidos húmicos dos sedimentos do Tietê foram isolados segundo o método sugerido pelo "International Humic Substances Society" (IHMS). ${ }^{(124)} \mathrm{O}$ sólido fino obtido apresentou uma coloração marron escura, típica de substâncias húmicas. A solubilização em meio alcalino foi instantânea para os ácidos húmicos investigados. A análise elementar foi realizada, a fim de se estimar os níveis de $\mathrm{C}$ $\mathrm{N}, \mathrm{H}$, e as razões (ou relaçōes) $\mathrm{C} / \mathrm{H}$ e $\mathrm{C} / \mathrm{N}$. Os resultados estão na tabela 22 : 
TABELA 22: resultados das determinações de $\mathrm{C}, \mathrm{N}$ e nos ácidos húmicos extraídos das amostras de sedimentos do Tietê.

\begin{tabular}{|l|c|c|c|c|c|}
\hline & \multicolumn{3}{c}{$C^{*}(\%)$} & \multicolumn{3}{r|}{$N^{*}(\%)$} & $H^{*}(\%)$ & $C / H^{* *}$ & $C / N^{* *}$ \\
\hline casa do Luís & 23,3 & 2,75 & 3,03 & 7,70 & 8,50 \\
\hline Rasgão & 12,3 & 1,90 & 3,18 & 3,90 & 6,50 \\
\hline Tecelagem & 17,3 & 2,01 & 2,77 & 6,20 & 8,60 \\
\hline ponte r.Tieté-Capivari & 5,24 & 0,43 & 1,77 & 3,00 & 12,2 \\
\hline entrada B.Bonita & 15,6 & 1,55 & 2,32 & 6,70 & 10,1 \\
\hline m.esquerda B.Bonita & 15,3 & 1,56 & 2,26 & 6,76 & 9,80 \\
\hline jusante B.Bonita & 14,78 & 1,29 & 2,44 & 6,06 & 11,5 \\
\hline Zé doCalção-B.Bonita & 29,15 & 2,49 & 2,96 & 9,85 & 11,7 \\
\hline m.direita- B.Bonita & 15,2 & 1,62 & 2,67 & 9,40 & 5,70 \\
\hline
\end{tabular}

*os valores apresentados referem-se a duplicatas de determinaçסes

** as razбes $\mathrm{C} / \mathrm{H}$ e $\mathrm{C} / \mathrm{N}$ referem-se à razăo de massa

Pode-se verificar que os valores de carbono encontrados nos ácidos húmicos dos sedimentos do Tietê estão distribuidos numa faixa de 5 a $29 \%$. Thurman ${ }^{(124)}$, estudando ácidos húmicos de diferentes compartimentos ambientais encontrou $56 \%$ de carbono em ácidos húmicos de solo e $50,5 \%$ de carbono em ácidos húmicos de água de rio. Esses resultados, embora não se refiram a ácidos húmicos de sedimentos, sugerem existir uma diferença significativa com relação a carbono. Esta diferença pode ser atribuida ao fato que em ambientes autóctones, livres de entrada de material externo, a formação dos ácidos é decorrente de processos naturais lentos, que propiciam a formação de substâncias com peso molecular elevado e uma natureza polimérica. No caso dos ácidos húmicos do Tietê, verificam-se valores muito inferiores aos valores dos ácidos húmicos aquáticos ou terrestres, pois tem-se um ambiente alóctone, em sua maior parte anóxido e com elevada taxa de processamento da matéria orgânica, justificando 
assim os baixos niveis de carbono verificados.

Os resultados obtidos para a razão $\mathrm{C}: \mathrm{N}$ propiciam sugerir a natureza da matéria orgânica presente. Segundo Meybeck ${ }^{(126)}$, as razões C:N são independentes de fatores ambientais, sendo, então considerada, uma propriedade conservativa, assim como as proporções de íons nas águas oceânicas. Ainda neste tema, Hedges et al. ${ }^{(127)}$ sugeriram que a razão $\mathrm{C}: \mathrm{N}$ tem valores médios para os rios do mundo de 8 -10 (razão de massa), sendo esta, sempre muito próxima à razão média encontrada para solos das bacias destes rios.

Ao aplicar-se a razão sugerida por Hedges es. al. ${ }^{(127)}$, pode-se notar que para as amostras do Tietê, as razões $\mathrm{C}: \mathrm{N}$ estiveram razoavelmente próximas desse intervalo, o que corrobora com a possibilidade dos ácidos húmicos extraídos das amostras serem realmente originários do solo da própria bacia do Tietê.

Buffle ${ }^{(178)}$ realizou um levantamento cuidadoso a respeito da existência de frações húmicas e fúlvicas sedimentares. Segundo este autor, há muito poucos estudos a respeito de substâncias húmicas de sedimentos, quando comparados a estudos de solos. Baseando-se nos resultados publicados na literatura, considera que a composição dos ácidos húmicos de solos diferem significativamente da composição encontrada para ácidos húmicos sedimentares. Para a porcentagem de carbono em ácidos húmicos de sedimento, são verificados valores de 15 a $35 \%^{(179-180)}$. Nossos resultados concordam totalmente com a faixa encontrada sugerida por outros autores. Com relação à razão $\mathrm{C} / \mathrm{H}$, considera-se que a razão encontrada em sedimentos $(6,9-9,5)^{(181-182)}$ seja muito mais baixa que a verificada para ácidos húmicos de solo $(\mathrm{C} / \mathrm{H}=12)$, indicando assim haver uma predominância de estruturas alifáticas. Os resultados verificados para os ácidos húmicos do Tietê estiveram numa faixa de 3 a 9,9 ; concordando novamente com os resultados publicados. Têm-se ainda que a razão $\mathrm{C} / \mathrm{N}$ verificada para ácidos húmicos de sedimentos pode variar de 6,5 a $8^{(182)}$ ou ainda de 9,4 a $14,1^{(179)}, \quad$ e 
que esta relação é a que compõe as cadeias periféricas dos ácidos húmicos. Nossos resultados foram de 6,5 a 12,2 ; concordando totalmente com os resultados acima. Buffle ${ }^{(178)}$ ressalta que os ácidos húmicos de sedimentos apresentam niveis baixos de grupos carboxílicos e fenólicos, e em contrapartida é verificado um elevado nível de grupamentos carbonilicos.

Em carater complementar às analises elementares de carbono, hidrogênio e nitrogênio, foram realizadas as varreduras espectrais no U.V.-VIS de algumas amostras de ácido húmico dos sedimentos do Tietê. Os resultados estão a seguir:

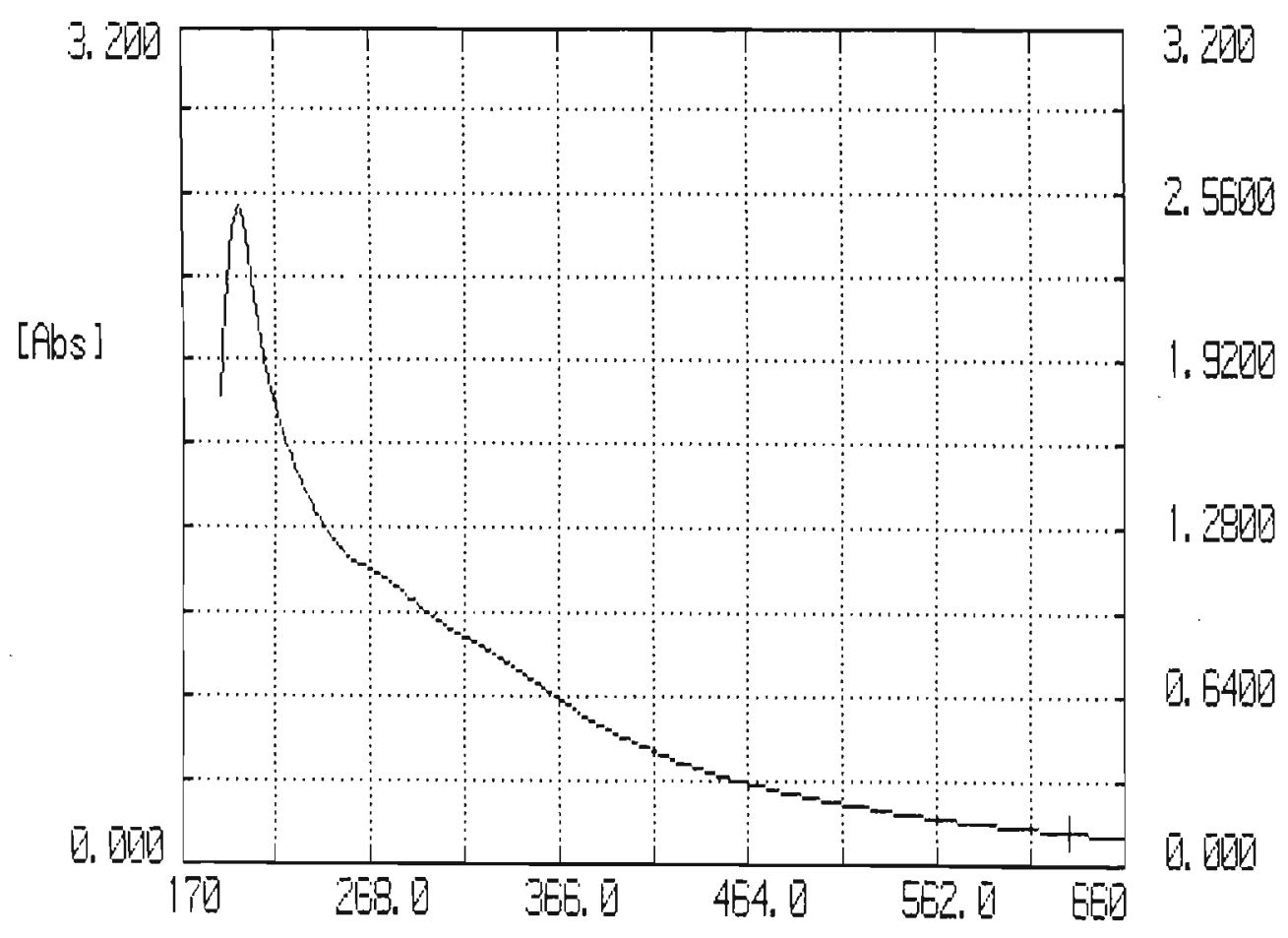

FIGURA 40: espectro de UV-VIS da amostra de ácido húmico presente no sedimento de casa do Luís (Pirapora) 


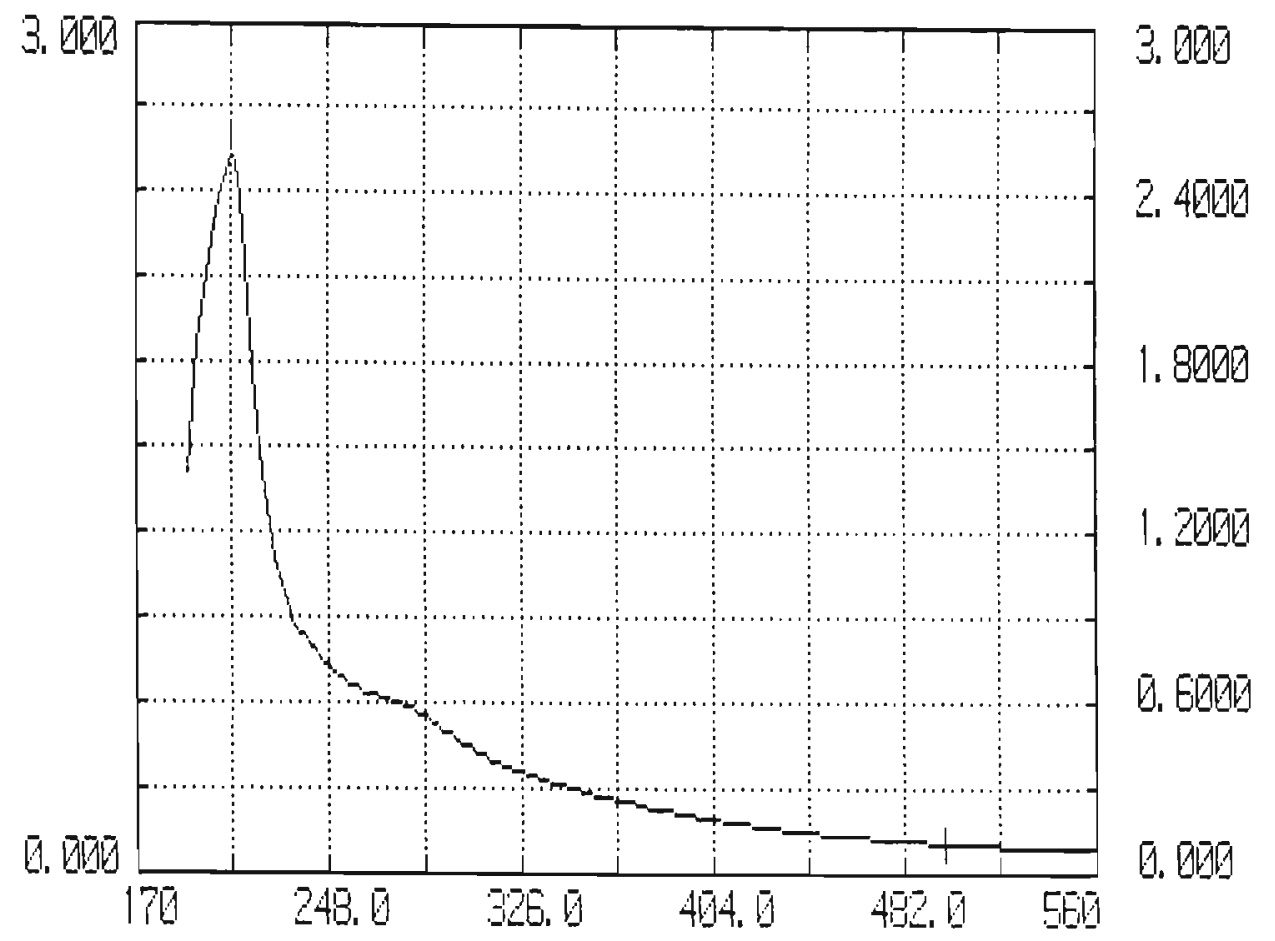

FIGURA 41: espectro de UV-VIS da amostra de ácido húmico presente no sedimento de Rasgão (Pirapora)

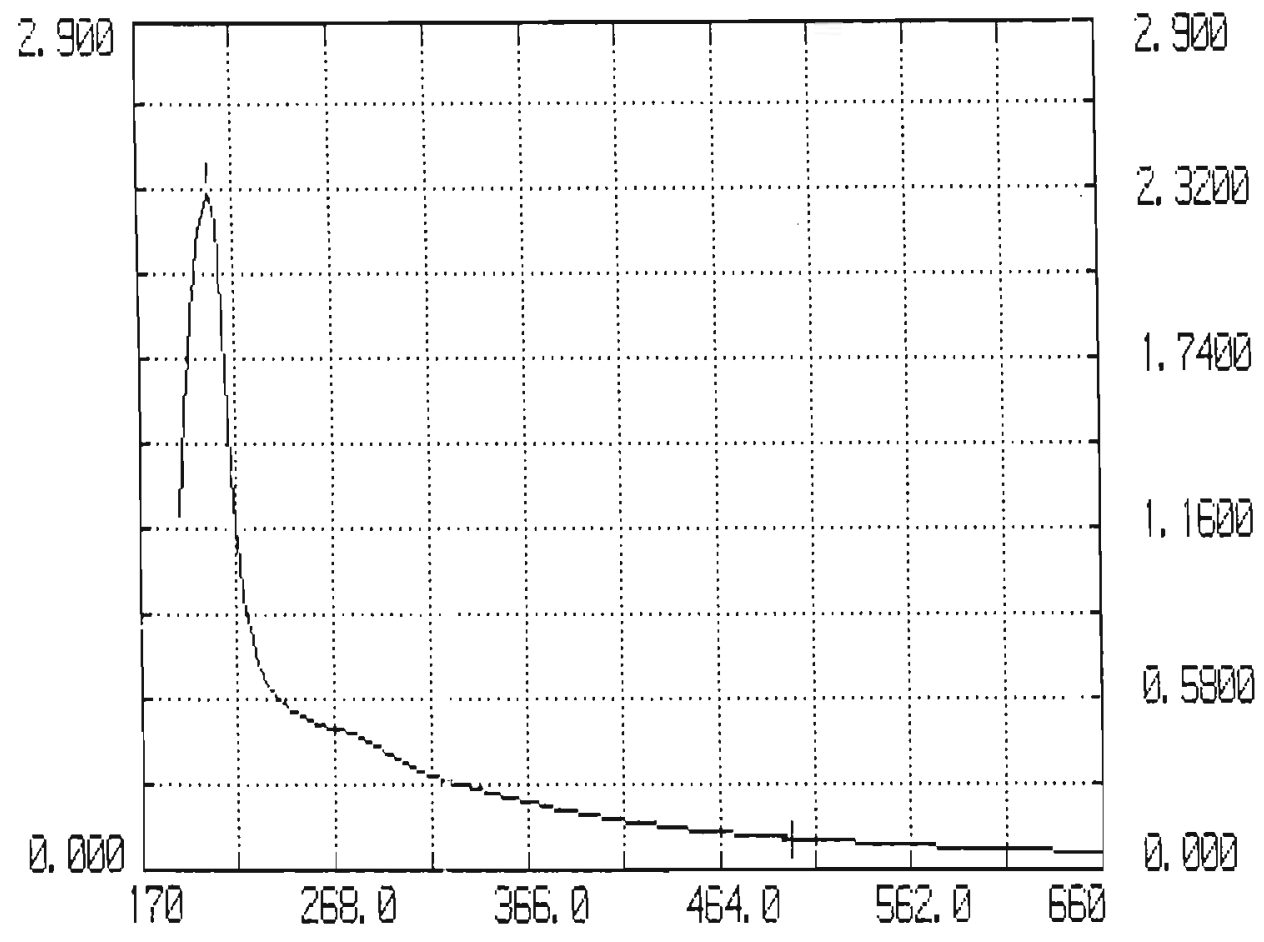

FIGURA 42: espectro de UV-VIS da amostra de ácido húmico presente no sedimento deTecelagem (Pirap:ra) 


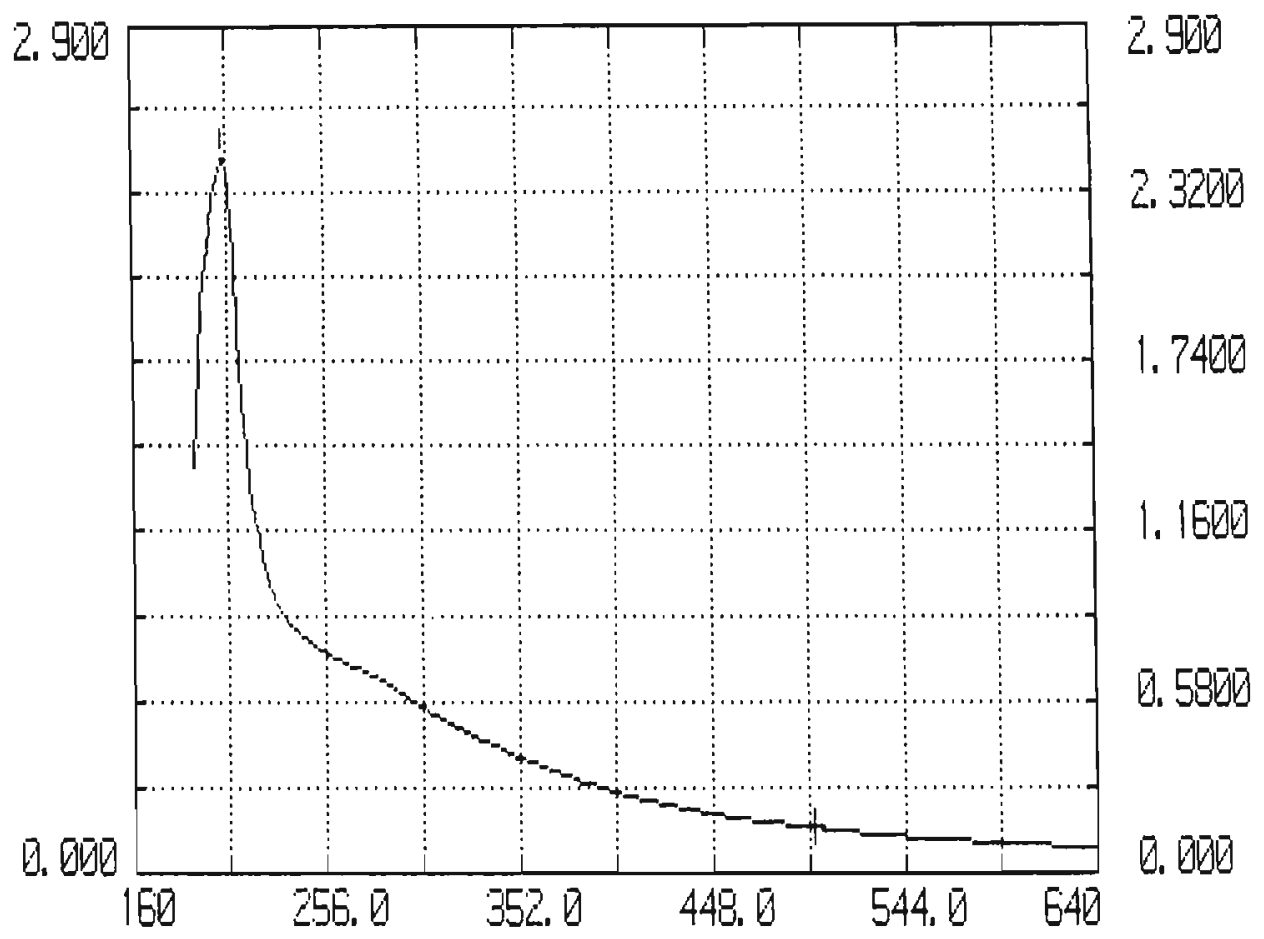

FIGURA 43: espectro de UV-VIS da amostra de ácido húmico presente no sedimento de entrada de Barra Bonita

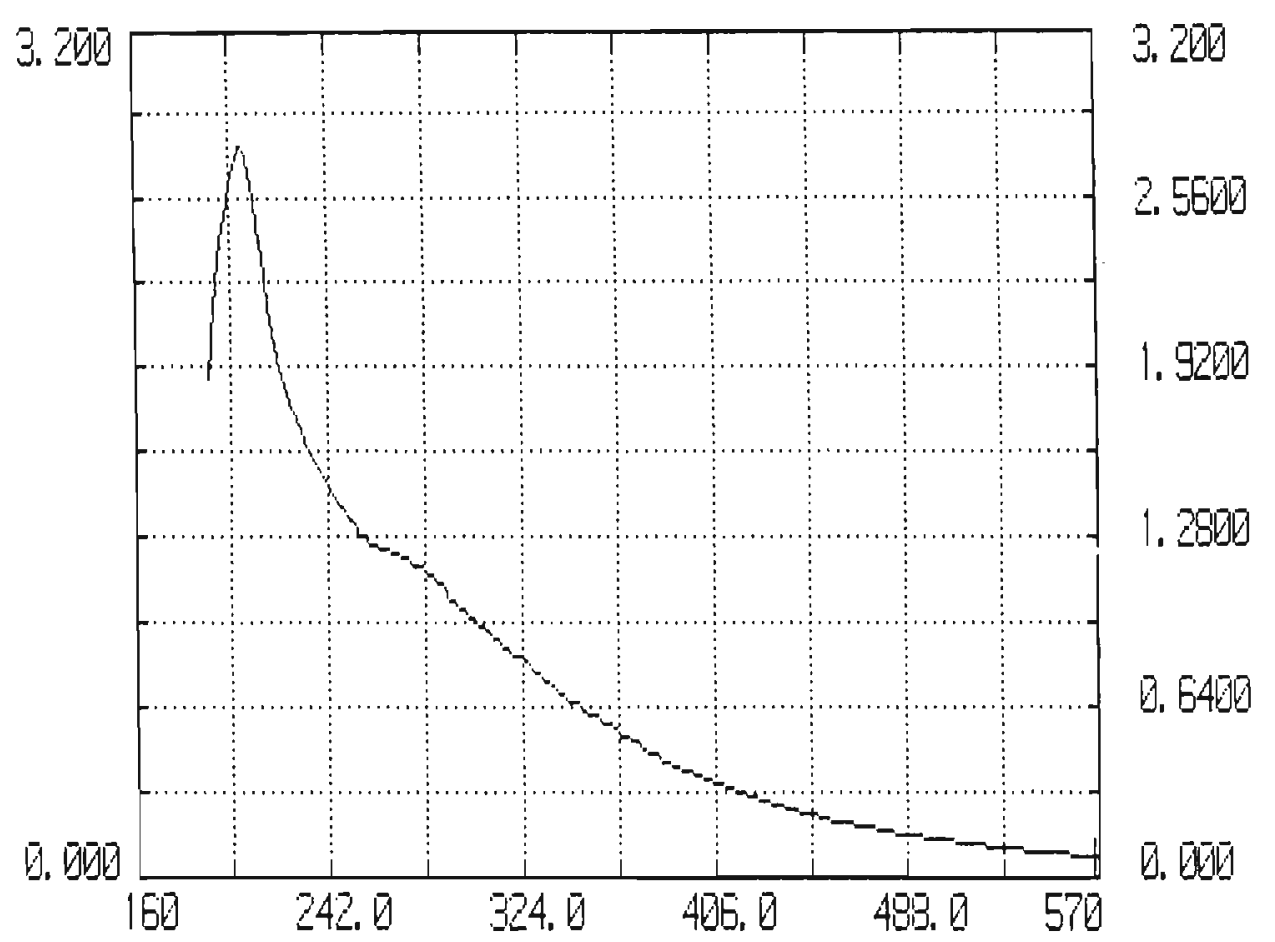

FIGURA 44: espectro de UV-VIS da amostra de ácido húmico presente no sedimento de entrada de Barra Bonita 
Os espectros determinados acima chamam a atenção por serem muito semelhantes entre si. O máximo de absorbância observado para a amostra de Pirapora (204 nm) está muito próximo dos valores encontrados para as amostras de Rasgão (208 nm), Tecelagem e Zé do Calção (206 nm) e entrada de Barra Bonita $(204 \mathrm{~nm})$. Por conseguinte, infere-se que provavelmente tratam-se de ácidos húmicos de mesma natureza (solos) e com estruturas semelhantes. Autores como Thurman ${ }^{(124)}$, Lawrence ${ }^{(183)}$ e Choudry ${ }^{(184)}$ estudaram as substâncias húmicas no U.V. e encontraram valores de máximos de absorbância muito próximos aos valores encontrados neste estudo. Importantes trabalhos foram realizados por Schnitzer ${ }^{(185)}$, que a partir do valor de $\lambda$ em $212 \mathrm{~nm}$, encontrou uma forte correlação entre os valores de absorbância e o número médio de pesos moleculares de diversos ácidos húmicos.

\subsection{2. discussão geral dos resultados obtidos neste estudo}

Primeiramente, devem-se considerar os aspectos mais preocupantes com relação a contaminação dos sedimentos do Tietê que são os metais pesados. Neste tema, é importante abordar melhor a questão que envolve a transferência desses metais para a biota aquática.

Uma importante comparação de resultados pode ser estabelecida entre metais pesados obtidos por extracãa em ácido diluído, $\mathrm{HCl} 0,1 \mathrm{M}$ (metais potencialmente biodisponíveis) com os resultados do método de extração

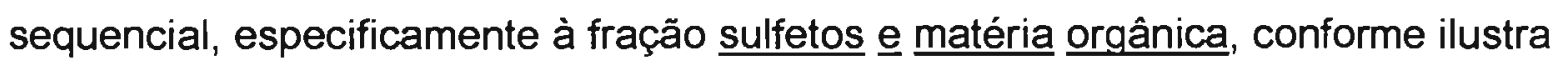
a figura 45 : 


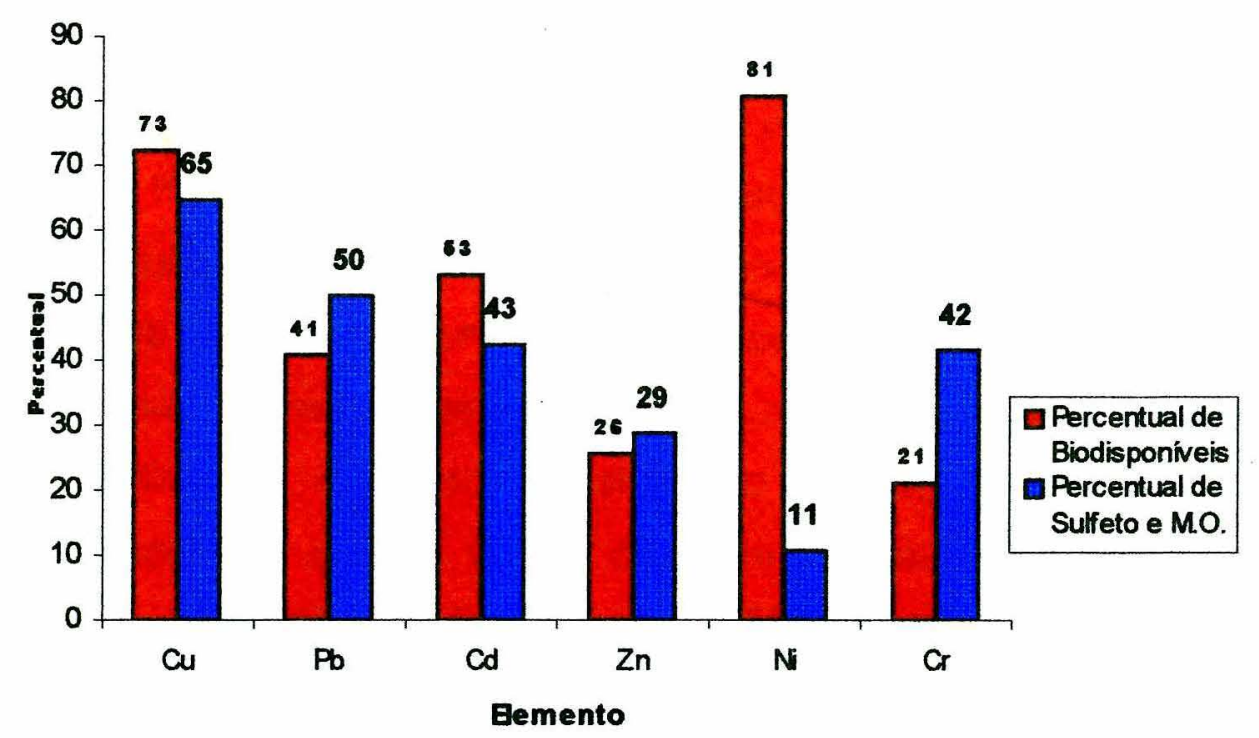

FIGURA 45: Resultados comparativos entre a fração obtida por extração sequencial e os metais potencialmente biodisponíveis para a amostra de Pirapora.

Exceto para $\mathrm{Ni}$ e $\mathrm{Cr}$, pode-se verificar que há uma significativa aproximação entre os valores dos dois estudos. 0 calculo da correlação $(0,9027)$ entre esses valores, sugere que boa parte dos extratos de $\mathrm{HCl}$ diluído sejam compostos de metais advindos da fase definida por Kersten e Förstner como sendo formada por sulfetos e matéria orgânica. Esta correlação pode ser considerada muito oportuna ao se levar em consideração os elevados níveis de sulfetos obtidos na amostra de Pirapora (14423 ppm ou $450 \mu \mathrm{mol} / \mathrm{g}$ ).

A princípio, não se deveria esperar que certos metais ligados a fases de sulfetos solubilizassem em $\mathrm{HCl}$ diluído, por conta de suas diminutas solubilidades, mesmo em meio ácido. Sabe-se que somente sulfetos tais como: FeS, ZnS, MnS seriam dissolvidos por este tratamento, e os demais sulfetos, tais como: $\mathrm{PbS}$, CdS, CuS e NiS não seriam solúveis em ácido diluído. No entanto, deve-se levar em consideração um importante fator: a formação de complexos, como íons polissulfetos.

$$
\begin{aligned}
& \text { B IBL IOTECA } \\
& \text { INSTITUTO DE QUIMICA } \\
& \text { UnIversidado de São Paulo }
\end{aligned}
$$


A secagem da amostra em estufa como sugerido, a $110^{\circ} \mathrm{C}$, realmente propicia modificações irreversíveis nas estruturas originais dos sedimentos ${ }^{(35,36,39}$, ${ }^{158,186)}$. Kersten e Förstner ${ }^{(35)}$, após secagem de amostras anóxidas de sedimentos em estufa, verificaram drásticas mudanças na proporção das formas químicas do material original. Foi verificado que há uma tendência dos metais se redistribuirem nas fases consideradas mais "lábeis", ou reativas dos sedimentos, por conta da oxidação dos sulfetos. O tratamento empregado às amostras do Tietê foi extremamente brando, $60^{\circ} \mathrm{C}$, diferente daquele sugerido na determinação de metais potencialmente biodisponiveis ${ }^{(45,46)}$. Isto foi realizado a fim de se minimizar ao máximo a possível oxidação da amostra. $\mathrm{O}$ aquecimento foi efetuado com o recipiente dentro de um sistema fechado à baixa pressão (estufa à vácuo).

Outro aspecto fundamental já apontado anteriormente, e que contribui para a explicação dos resultados comparativos $(r=0,903)$, vem da possível formação dos complexos de polissulfetos dos metais. a certeza da proteção das oxidações das amostras durante a secagem está nos experimentos realizados que mostram a relação linear entre as medidas de $E_{H}$ e de SAV.

A formação de polissulfetos ocorre pela reação de sulfetos com enxofre elementar, conforme foi explanado nas equações 3.2 a 3.6. Esta formação pode ser entendida através da eq. 3.1, ou mesmo pela reação de Fe (III), ou mesmo $\mathrm{MnO}_{2}$, componentes da matriz do sedimento com íons $\mathrm{S}^{2-}$. A confirmaçào da presença de íon polissulfeto foi facilmente obtida pela reação do sedimento com $\mathrm{HCl} 6 \mathrm{M}$, durante a extração dos sulfetos voláteis, na ausência de ar, obtendo-se enxofre elementar, segundo a reação ${ }^{(79,80)}$.

$$
\left[S_{n}\right]^{2-}+2 H^{+} \rightarrow(n-1) S^{0}+H_{2} S
$$

Outro fator que contribui para a confirmação da presença de íon polissulfeto são as medidas de $E_{H}$, obtidas do sistema reversivel (Nernstiano) e que mostrou tratar-se de sistema com 2 elétrons. Frisa-se que o sistema $\mathrm{S}^{2} / \mathrm{S}^{0} \mathrm{e}$ 
irreversivel, e portanto, certos autores ao considerarem o gráfico $E_{H}$ versus $p S$, não mencionam o fato acima descrito, atribuindo as medidas de $E_{H}$ ao par redox $\mathrm{S}^{2-} / \mathrm{S}^{0}$.

O sistema $\left[S_{n}\right]^{2-} / S^{0}$ deve ser o responsável pela formação de $\mathrm{H}_{2} \mathrm{~S}$ na determinação de SAV, conforme descrito. A reação acima $(3,14)$, apresenta a hipótese de formaçào intermediária de uma espécie protonada do ânion polissulfeto, liberando os metais dos complexos. Para isto, realizamos uma série de experimentos tratando o sedimento de casa do Luís com $\mathrm{HCl} 0,1 \mathrm{M}$, à quente e $2 \mathrm{M}$ à quente. Assim, à frio, conforme foi realizado neste trabalho, baseado no protocolo para a determinação de metais potencialmente biodisponiveis, estes seriam liberados pela protonação do íon polissulfeto. À quente, o íon polissulfeto protonado seria decomposto, formando $\mathrm{S}^{0}$ e $\mathrm{H}_{2} \mathrm{~S}$, conforme a reação já descrita. Assim, com a liberação de $\mathrm{H}_{2} \mathrm{~S}$, íons de $\mathrm{Pb}, \mathrm{Cd}$ e $\mathrm{Cu}$ poderiam precipitar com o mesmo. Os resultados abaixo mostram que esta hipótese é extremamente provável:

TABELA 24 Resultados de alguns metais obtidos por tratamento com $\mathrm{HCl}$, em diferentes condições de concentração de ácido e de temperatura.

\begin{tabular}{|c|c|c|c|}
\hline metal, ppm & HCI 0,1 M (à frio) & HCl 0,1M (à quente) & , HCl 2 M (à quente) \\
\hline $\mathrm{Cu}$ & 111 & 54 & 50 \\
\hline$P \boldsymbol{P b}$ & 61 & 29 & 19 \\
\hline $\mathrm{Cd}$ & 4,0 & 2,7 & 0,95 \\
\hline
\end{tabular}

Experimentos qualitativos realizados em nosso laboratório mostraram que os iíons $\mathrm{Cu}^{2+}$ precipitam e complıxam com o excesso de polissulfetos. Os íons de $\mathrm{Pb}$ e de $\mathrm{Cd}$ precipitam em parte apenas.

Os casos verificados para $\mathrm{Ni}$ e $\mathrm{Cr}$, que não apresentaram correlação entre

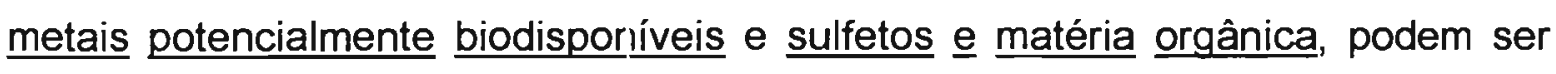
explicados: Ao se observar a figura 28 , que mostra a distribuição dos metais nas diversas fases que compõem o sedimento, pode-se verificar que o níquel se 
distribui em todas as fases, e que somente $10 \%$ do seu total está na fase de sulfetos e matéria orgânica. Porisso, não se poderia realmente esperar uma concordância entre esses resultados. Já o cromo, apesar de $42 \%$ de seu total estar presente nesta fase, não forma sulfetos, pois seu hídróxido é mais insolúvel $\left(\mathrm{Ks}=3,6.10^{-31}\right)$. Isto ocorre também para outros elementos, como $\mathrm{Al} \mathrm{e} \mathrm{Mg}$. Dess forma, é possivel entender-se porque o resultado de cromo não se correlaciona com os demais.

No caso de Barra Bonita, nenhuma correlação importante foi observada, devido aos pequenos níveis de sulfetos verificados nas amostras. Isto explica também o fato de Barra Bonita não apresentar correlação entre os valores de $\Xi_{\mathrm{H}}$ e de $\mathrm{pS}$, conforme verificado no primeiro trecho de estudo.

A formação de complexos de polissulfetos de metais insolúveis tem sido um tema de importantes discussões, principalmente em ambientes com elevadas concentrações de sulfeto.

O fenômeno da existência de espécies de metais traço solubilizadas em águas ricas em $\mathrm{H}_{2} \mathrm{~S}$ vem já há algum tempo sendo apontado, embora insufuicientemente explicado. Brooks ${ }^{(187)}$ e Presley ${ }^{(188)}$, estudando sedimentos de um braço de água de Saanich, ambiente anóxido e sulfídrico, verificaram que as concentraçōes de metais ( $\mathrm{Pb}, \mathrm{Cu}, \mathrm{Cd}, \mathrm{Ni}$ ) dissolvidos na coluna d'água excediam enormemente os valores esperados com base nos simples cálculos de solubilidade como sulfetos de metais. Resultados similares foram obervados em sedimentos pantanosos, próximos a Georgetown. No entanto, somente simples inferições quanto à presença de íons de polissulfetos foram levantadas.

Gardner $^{(187)}$ realizou um estudo, no qual desenvolveu um modelo teórico, a fim de testar a hipótese que os ácidos húmicos marinhos controlavam a solubilidade de metais dissolvidos em águas ricas em $\mathrm{H}_{2} \mathrm{~S}$. Este autor concluiu que, na realidade, os complexos de polissulfetos são os principais controladores da solubilidade de metais nessas águas, contrariando os resultados de equilibrio esperado para os sulfetos insolúveis. Vários trabalhos enfatizam a participação 
dos polissulfetos de metais pouco solúveis em ambientes ricos em sulfetos ${ }^{(79-80,188-}$ 189). No caso dos ambientes sulfídricos, considera-se que a formação dos polissulfetos se dá, não devido à oxidação de $\mathrm{H}_{2} \mathrm{~S}$, conforme a equação 3.7., mas sim a uma reação auto catalítica entre o enxofre nascente e os íons de sulfeto dissolvidos $^{(190)}$. No entanto que os experimentos acima descritos consideram a possibilidade de formaçào de íon de polissulfeto meramente por cálculos termodinâmicos, e não com uma sustentação experimental que seria fundamental para se realizar esta tão importante consideração. Apesar de alguns autores ${ }^{(191)}$ sugerirem um controle dos metais por parte de ácidos húmicos, através da formação de complexos lábeis, principalmente os de $\mathrm{Pb}, \mathrm{Cd}$, Cu e de $\mathrm{Ni}$, Gardner (187) demostrou através de cálculos que as constantes condicionais desses humato-complexos, embora não negligenciáveis, não podem sugerir a sua formação quando comparadas às dos polissulfetos-complexos. Conforme é apontado por Stumm e Morgan ${ }^{(19)}$, a formação de complexos organometálicos é frequentemente postulada para explicar a ocorrência de metais dissolvidos em concentrações mais elevadas que as calculadas dos valores conhecidos de produtos de solubilidade. Volta-se a frisar novamente que tais considerações por parte destes autores são destituídas, conforme discutido acima, de uma caracterização teórica, sendo este caso, referente aos ácidos húmicos e outros ligantes orgânicos, hipóteses sustentadas meramente por exclusão. $O$ modelo apresentado para as amostras de sedimentos do Tietê tem o realçe experimental, fundamental para inferir parâmetros referentes à qualidade ambiental deste ambiente.

As considerações apresentadas a respeito de polissulfetos, como os de $\mathrm{Cu}$, $\mathrm{Cd}, \mathrm{Pb}$ e $\mathrm{Ni}$, e as chances de realmente estarem presentes nas águas do Tietê, sugeridas a partir dos experimentos de $E_{H}$ e pS, são de extrema importância em nossos estudos, pois permitem inferir que realmente uma boa parte dos metais nas condições anóxidas e sulfídricas verificadas no Tietê podem estar lábeis na coluna d'água, mesmo em condições tão adversas quanto às que o rio apresentou neste trabalho, o que sem dúvida sugere uma atenção especial. 
No caso do Tietê, é realmente difícil sugerir um. controle dos metais na coluna d'água por parte dos complexantes organicos naturais, como os ácidos húmicos, num meio predominantemente sulfídrico como o deste rio. Portanto, parece suficientemente pertinente inferir-se a participação de íons de polissulfetos na concentração dos metais potencialmente biodisponiveis presentes no ambiente de Pirapora, bem como em todo o trecho sulfídrico e anóxido do Tietê.

Pelos experimentos efetuados durante a extração sequencial, ficou evidenciada a existência, já apontada por alguns autores ${ }^{(9,35,36)}$ deMnO$_{2}$ e $\mathrm{Fe}(\mathrm{OH})_{3}$ no cerne do sedimento, como remanescente da constituição mineralógica do mesmo. A fase de extração com $\mathrm{NaOAc}$ mostrou essa evidência. Com isso, a fase de extração posterior, com $\mathrm{NH}_{2} \mathrm{OH}$ em $\mathrm{HCl}$ diluído, ficou praticamente sem espécies redutiveis.

Em função dos resultados obtidos, colocamos em questionamento o critério do uso deHCl 0,1 M na extração de metais potencialmente biodisponíveis, pois consideramos que os autores idealizadores do critério em questão ${ }^{(35,36)}$, não devem ter levado em consideração a presença de $\mathrm{MnO}_{2}$ e de $\mathrm{Fe}_{2} \mathrm{O}_{3} \cdot \mathrm{nH}_{2} \mathrm{O}$, capazes de passarem à solução seus íons reduzidos, pela ação de $\mathrm{HCl} 0,1 \mathrm{M}$ via redox (com os íns sulfetos e polissulfetos).

Sugerimos que, provavelmente, os metais potencialmente biodisponiveis possam melhor serem representados pelo critério com $\mathrm{HCl} 0,1 \mathrm{M}$, se, primeiramente, o sedimento for extraído com $\mathrm{NH}_{2} \mathrm{OH}$ em $\mathrm{HCl}$ diluído, e filtrado, a fim de se eliminarem os óxidos de manganês (IV) e de ferro (III) presentes no cerne do sedimento.

Outro experimento que realizamos em nosso laboratório e que abre perspectivas para uma abrangência maior na avaliação dos sedimentos e seu ambiente (rio) foi o da aeração do sedimento. Tomamos $1,57 \mathrm{~g}$. do sedimento de Pirapora, devidamente seco, o colocamos em um erlenmeyer de $125 \mathrm{~mL}$. Foram adicionados $50 \mathrm{~mL}$ deágua deionizada e o erlenmeyer conectado a uma trompa de vácuo comum, sendo aerado por um período de 2 horas. A suspensão foi 
filtrada, podendo-se observar um avermelhamento do precipitado e o filtrado incolor. Este filtrado apresentou um $\mathrm{pH}$ final $=6,0$ e foi analisado porabsorção atômica. No filtrado, os valores encontrados para $\mathrm{Pb}, \mathrm{Cd}$ e $\mathrm{Cu}$ foram menores que o limite de quantificação do método. Tal fenômeno foi resultanteda inevitável adsorção dos compostos presentes (surge a seguinte pergunta: Até que ponto houve oxidação total de sulfetos e polissulfetos a sulfato?) em $\mathrm{MnO}_{2}$ e $\mathrm{Fe}(\mathrm{OH}) 3$, formados pela aeração durante 2 horas. É indubitável que íons fosfato devem estar adsorvidos em nosso sedimento. Com isso, tem-se a possibilidade de se poder imaginar o que aconteceria com os metais pesados diante de uma possivel aeração do rio Tietê, ficando em aberto o comportamento de ânions solúveis, como nitrato. Abrem-se inúmeras questōes: Será que uma aeração controlada não poderia contornar o problema dos metais e dar ensejo para um controle maior da presença de nutrientes (nitratos, por exemplo?). Nesse sedimento submetido aos efeitos de aeração, com a coluna d'água simultaneamente aerada, a mobilidade do fosfato teria que ser estudada, assim como a dos metais adsorvidos, etc. Em outras palavras: qual seria a mobilidade e a biodisponibilidade dos metais nessas condições? Esta questão permanece ainda em aberto. 


\section{CONCLUSÕES}

1. Com relação à conservação e a estabilidade das amostras de sedimentos do Tietê, pode-se concluir que:

1.1- As amostras de sedimentos provenientes de ambientes tipicamente estressados, como é o caso do Rio Tietê, necessitam receber uma atenção especial, durante as etapas de coleta, manuseio e conservação. A manutenção em condições anóxidas é fundamental para se ter uma garantia de sua integridade. Amostras desta natureza, em condiçõess controladas e cuidadosamente monitoradas, como as desenvolvidas neste trabalho, podem refletir as condições originais de amostragem por longos períodos, e, com um determinado grau de confiança, os ambientes que representam. Mostramos em nossos experimentos que, as amostras, uma vez coletadas e guardadas em refrigerador e em atmosfera inerte, podem manter suas características por um longo tempo.

1.2- As medidas $\mathrm{E}_{\mathrm{H}}$ e de $\mathrm{pH}$ para fins de acompanhamento de preservação de amostras de sedimentos foram significativamente favoráveis, além de serem técnicas até certo ponto inéditas nesta finalidade de trabalho. Pelo fato do sedimento constituir-se em um meio heterogêneo e quimicamente complexo, deve-se frisar que os eletrodos devem estar cuidadosamente calibrados (no caso do eletrodo de $\mathrm{pH}$ ) e checados (no caso do eletrodo de $\mathrm{Pt}$ ), a fim de se ter uma maior confiabilidade dos resultados.

Concluímos que medidas de caracterização de sedimentos devem ser de $E_{H}$, de $p H$ e de $S A V$, em conjunto.

2. Com relação às técnicas utilizadas na caracterização dos sedimentos do Tietê, podem-se tecer algumas conclusões:

2.1. As determinações do potencial redox revelaram que o ambiente do Tietê desde o trecho de Pirapora (próximo à região metropolitana de São Paulo) até 
a entrada do reservatório de Barra Bonita é predominante anóxido (leituras de valores negativos de potenciais, vs. $\mathrm{Ag} / \mathrm{AgCl}$ ), controlados em boa parte do trecho estudado pela concentração de espécies complexas de enxofre, principalmente polissulfetos. A qualidade da água também segue este mesmo padrão, visto que a camada redox anóxida avança à coluna d'água em grande extensão.

2.2. As técnicas analíticas testadas na determinação de sulfeto ácido volátil merecem ser discutidas: a biamperometria pode ser utilizada somente através de uma adaptação qua permitisse introduzir-se a amostra (o produto do arraste de sulfeto volátil) em uma célula com uma solução de $I_{2}$, e acompanhar-se a queda de corrente a cada adição. A técnica polarográfica, por basear-se na formação de filme ( $\mathrm{HgS}$ ), não apresenta repetibilidade de análise, não podendo, segundo nossos estudos, ser utilizada em amostras reais para fins quantitativos.

A potenciometria com eletrodo íon-seletivo foi a técnica mais viável de ser utilizada para sulfeto volátil, apresentando um intervalo linear entre 0,08 a 2,00 ppm, adequado para as concentraçōes verificadas nas amostras do Tietê. O método de determinação mais favorável é o de curva de calibração e leitura simultânea de amostra. O método de adição de padrão mostrou-se impreciso, além de não apresentar nenhuma vantagem em relação ao método de curva de calibração, pois exige a determinação do "slope" da curva a cada dia de análise.

O sistema "gerador" de sulfeto ácido volátil desenvolvido neste trabalho é extremamente simples e apresenta bons valores de recuperação para amostras reais e para padrōes de sulfeto. As condiçōes mais favoráveis encontradas para promover 0 arraste de SAV foram: fluxo de gás, 4 bolhas/segundo; concentração de $\mathrm{HCl}, 6 \mathrm{M}$ e tempo de arraste de 30 minutos.

2.3. A análise granulométrica apresentou um nivel bastante aceitável de precisão entre análises (10\%) e a condição experimental adotada, como 
tratamento por ultrassom para desagregar as partículas, em desacordo com alguns autores, mostrou-se altamente eficiente para as amostras de sedimentos do Tieté.

2.4. A determinação dos metais pesados presentes nos sedimentos ( $\mathrm{Mn}, \mathrm{Fe}$, $\mathrm{Cu}, \mathrm{Pb}, \mathrm{Cr}, \mathrm{Cd}, \mathrm{Zn}$ e $\mathrm{Ni}$ ) por espectrofotometria de absorção atômica apresentou poucos problemas relacionados a matriz, todos contornáveis. Deve-se tomar um certo cuidado nas determinações do método de extração sequencial, principalmente na etapa 4 , com o tampāo oxalato, que causa uma significativa interferência durante a análise.

A abertura de amostras de sedimentos por microondas foi de grande valia, quando comparada à técnica convencional (bomba de teflon). 0 ciclo de aquecimentos intercalado com períodos de repouso foi sensivelmente favorável às determinações. Soluções límpidas foram obtidas num tempo de aproximadamente 25 minutos. O acompanhamento da técnica de abertura das amostras com material de referência mostrou ser uma boa forma de acompanhar a eficiência e a confiabilidade (exatidão) das determinações realizadas. Devido à problemas já mencionados quanto à morosidade, uso de oxalato e eventuais questionamentos quanto ao uso dos resultados das várias etapas de extração sequencial, achamos que a extração com $\mathrm{HCl} 0,1 \mathrm{M}$, que fornece os metais, definidos como potencialmente biodisponiveis, atinja melhor os objetivos almejados, com a possivel consideração já mencionada, referente à presença de $\mathrm{MnO}_{2}$ e $\mathrm{Fe}_{2} \mathrm{O}_{3}$. $\mathrm{nH}_{2} \mathrm{O}$, no cerne dos sedimentos.

2.5. Deve-se ressaltar que a técnica de Microscopia Eletrônica de Varredura foi muito interessante no esclarecimento de aspectos texturais dos sedimentos. Através desta técnica, pode-se notar a presença de formações minerais, elementos contaminantes (metais pesados) e alguns até peculiares, como $\mathrm{Nb}$, e até mesmo terras raras, especificamente $\mathrm{Ce}$ e Sm, em Pirapora. 
2.6. A determinação de carbono nas amostras de sedimentos, realizada através da técnica descrita por Olausson ${ }^{(192)}$ foi de muita valia, pois permitiu estimar a matéria orgânica presente no sedimento.

2.7. o isolamento e a caracterização das substâncias húmicas dos sedimentos do Tietê foram importantes para se estimar a matéria orgânica refratária, e apresentou resultados confiáveis de microanálise e dados espectroscópicos. Vale ressaltar que, assim como outros aspectos abordados neste trabalho, o conhecimento dos ácidos húmicos do Tieté representa uma significativa contribuiçāo ao estudo dessas substâncias neste campo, conforme salienta Buffle ${ }^{(178)}$.

3. Com relação aos resultados analíticos observados para as amostras do Tieté e suas implicações ambientais, pode-se concluir que:

3.1. As determinaçōes de sulfeto ácido volátil revelaram valores muito elevados em Pirapora ( $450 \mu \mathrm{mols}$ de SAV por grama de sedimento), que tendem a diminuir conforme o rio se dirige no sentido de Barra Bonita. No trecho que vai de Pirapora até o ponto amostral de ponte do rio Tietê-Capivari, - $E_{H}$ indica um elevado nível de estagnação na regiảo de Pirapora do Bom Jesus e ainda se correlaciona linearmente com pS $(0,9979)$, indicando assim haver um controle deste potencial por espécies termodinamicamente reversiveis de enxofre, dada pelo par redox formado entre polissulfetos e enxofre elementar $\left(S_{n}{ }^{2-} / S^{0}\right)$. Tal consideração foi comprovada em nossos experimentos.

Através dos resultados de SAV e de $E_{H}$ determinados em nossos estudos, foi possível caracterizar o trecho entre Pirapora e Barra Bonita como anóxido e sulfídrico , e o trecho correspondente ao reservatório de Barra Bonita como pós-óxido e não sulfídrico. Tais classificaçōes são muito importantes para a geoquímica da região do Tietê. 
3.2. As determinaçōes de carbono orgânico e matéria orgânica esclarecem que o processamento desses materiais é muito rápido por parte dos microorganismos decompositores, nas condiçōes anóxidas verificadas em boa parte do trecho de estudo. Os niveis de carbono verificados nas amostras de sedimento do Tieté, bem como as relaçōes $\mathrm{C} / \mathrm{N}$ permitem inferir que este material é de origem alóctone, gerado na bacia de drenagem. Tais inferências são corroboradas através das relaçōes $\mathrm{C} / \mathrm{N}$ e $\mathrm{C} / \mathrm{H}$ observadas para os ácidos húmicos, concordando com esta hipótese.

3.3. Os estudos relacionados aos metais pesados dos sedimentos do Tieté permitem considerar que Pirapora apresenta niveis elevados de todos os metais pesados, quando comparados aos valores de referência global, folhelho médio, confirmado também pelos espectros de microscopia eletrônica de varredura. No entanto, Barra Bonita apresenta níveis comparáveis aos do folhelho médio e também aos níveis levantados a cerca de 15 anos atrás. Isto mostra que a hipótese de Pirapora estar "exportando" metais para o reservatório de Barra Bonita, confurme sugerem alguns autores, está totalmente descartada até o presente. Têm-se ainda que os resultados do método de extração sequencial revelaram que $\mathrm{Zn} \mathrm{Ni} \mathrm{e} \mathrm{Cd}$ apresentam metais nas fraçōes mais sensiveis a variações redox e de $\mathrm{pH}$ (trocável, ligados a carbonatos e facilmente redutivel). Os demais elementos apresentaram um perfil de distribuição nas fases corısideradas mais inertes do sedimento, como:

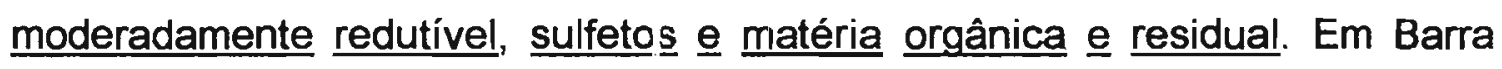
Bonita, os metais foram detectados nas frações consideradas inertes do sedimento, corroborando a idéia de não haver contaminação por metais pesados neste reservatório. Com relaçăo à aplicação da extração sequencial, este método mostrou ser muito 'edioso, devido ao longo período para ser concluído (cerca de 25 dias), alér de exigir o manuseio da amostra nas quatro primeiras etapas em atmosfera de $\mathbf{N}_{2}$. O método ainda apresentou problemas 
de precipitação de metais (Fe e Mn) nas primeiras etapas de extração.

O método de extração de metais potencialmente biodisponíveis é muito mais rápido de ser aplicado, apresenta boa precisăo, e indicou que em Pirapora há metais com potenciais de biodisponibilidade significativamente elevados como Cu (73\%), Pb (41\%), Cd (53\%), Ni (81\%) e em menor extensão $\mathrm{Zn}(26 \%)$ e $\mathrm{Cr}(21 \%)$. Quando são comparados os resultados de metais potencialmente biodisponiveis com os resultados da fração sulfetos e matéria orgânica, verifica-se uma correlação $(0,9027)$ para $\mathrm{Cu}, \mathrm{Pb}, \mathrm{Zn}$ e Cd; não sendo verificada para $\mathrm{Cr}$ e Ni. Pode-se inferir que esta correlação se dá devido à presença de complexos, principalmente polissulfetos dos metais que, durante o tratamento ácido, liberam os íons dos metais neste $\mathrm{pH}$, aumentando a fração biodisponível desses metais. Portanto, vale ressaltar que embora as amostras do Tietê, apresentem condições redox e de pH desfavoráveis à liberação de metais para a coluna d'água, pode exister uma grande quantidade de espécies complexas de polissulfetos dissolvidas, se contrapondo ao modelo térico de cálculo de solubilidade dos sulfetos metálicos, o que sugere uma forte potencialidade de se transferirem para a biota aquática.

Os resultados verificados possibilitam considerar-se que a associação de técnicas analíticas como as utilizadas neste estudo é de significativa reelevância, podendo ser utilizadas tanto no estudo, quanto no monitoramento de ambientes naturais.

Com relação às considerações ambientais pertinentes aos estudos realizados, pode-se inferir que ao longo de todo o trecho estudado, confirmase o fato de que a região de Pirapora atua como um verdadeiro "hot spot" para todo o sistema hídrico do Tietê. Os níveis totais, a biodisponibilidade e as formas químicas que os metais pesados apresentam para a amostra de Pirapora conduzem a um quadro preocupante de contaminaçăo à biota aquática. A granulometria encontrada em Pirapora e regiāo, fraçōes elevadas de silte e argila, conduz a uma elevada reatividade dos sedimentos nos 
processos entre a fase sólida e a água.

O reservatório de Barra Bonita não pode ser encarado ainda como um ambiente em estágio de impacto ambiental, apesar de já apresentar problemas de eutrofização, dada pelos nutrientes de efluentes locais.

Finalmente, pode-se concluir que um dos objetivos principais deste trabalho, que era o de estabelecer um protocolo para os estudo de sedimentos, foi estabelecido a pleno contento.

Pode-se ainda salientar que outros objetivos foram alcançados, como o esclarecimento das medidas de $E_{H}$, pela presença de ion polissulfeto. Isso propicia uma explicação significativamente plausivel, com enfoque experimental, quanto ao aparecimento de íons de metais pesados em soluções aquosas, após tratamento com $\mathrm{HCl}$. Críticas construtivas com respaldo experimental ao método de extraçăo sequencial $\theta$ ao uso do método de extração dos metais potencialmente biodisponíveis, com $\mathrm{HCl}$ 0,1 M.

\section{PROPOSTAS FUTURAS DE ESTUDOS}

Antes da realização deste trabalho, pde-se considerar que o Tietê havia sido muito pouco estudado até então, em termos do compartimento sedimento e sua participação nos processos bióticos e abióticos. A título de encaminhamento de propostas futuras para o estudo do Rio Tieté, torna-se oportuno apresentar algumas sugestōes pertinentes a este tema. Com relação aos sedimentos, pode-se sugerir um número maior de campanhas, a fim de se estabelecer uma relação de sazonalidade, por exemplo, entre períodos de cheias e de estiagem. Devido aos resultados preocupantes sobre a presença de polissulfetos, e consequente solubilização de inúmeros íons de metais em Pirapora, com formação de complexos, fica evidente que um ambiente rico em sulfetos não necessariamente representa um "trap" de metais tóxicos, como alguns preferem acreditar, mas um ambiente potencialmente reativo de espécies tóxicas e sujeitas à remobilização nos sedimentos. Nesse sentido, 
estudos sazonais poderāo proporcionar um maior conhecimento das ciclagens óxidas e anóxidas que naturalmente devem ocorrer neste ecossistema, e a intensidade de remobilização dos metais.

Outro importante trabalho a ser realizado no Tietê poderia ser apontado como uma detalhada investigação dos niveis de metais pesados presentes nas águas intersticiais dos sedimentos. Esta informação pode ser muito importante na avaliação e dinâmica da interface coluna d'água / sedimento.

Ressalte-se ainda a importância da determinaçāo dos materiais em suspensão, ou materiais particulados, principalmente em ambientes de estagnação como o de Pirapora, que pode revelar de forma segura a dinâmica de transferência de espécies para a biota aquática. Isto se daria a partir da instalação de armadilhas coletoras, durante períodos 15 dias. Alguns parâmetros tais como taxa de sedimentação, carbono orgânico, metais, nutrientes, etc. colaborariam de forma decisiva na interpretação da dinâmica do Tietê, particularmente o papel de Pirapora no processo como um todo.

Tratando-se das medidas de remediação ao Tietê, podem se realizar experimentos em campo e em laboratório relacionados aos efeitos de modificaçōes de $\mathrm{pH}$ e de condiçōes redox aos sedimentos anóxidos. Isto se daria a partir do estudo dos efeitos causados por operações tais como: aeraçāo e dragagem, e suas implicações a nível de disposição de metais à biota aquática e do balanço de nutrientes. Sabe-se que tais estudos devem ser executados com extremo controle, em virtude dos efeitos negativos apontados por diversos autores com relação a açỏes desta natureza, e suas implicações nos sedimentos de fundo contaminados por metais pesados ${ }^{(9,35,36,110,114,169,186)}$. Os experimentos iniciais por nós executados incentivam-nos a esse estudo mais abrangente. Com relação a este tema, vale ressaltar os importantes trabalhos de Förstner e Salomons ${ }^{(186)}$ que relatam vários estudos de caso semelhantes ao do Tietê, sobre remobilização de metais em ambientes anóxidos. Isto pode ser devido aos complexos de metais com polissulfetos, por nós evidenciados, e que até o presente foi subjetivamente considerado por outros autores. Há um consenso entre alguns grupos de que experimentos que 
envolvam ajustes de $\mathrm{pH}$ em faixas ligeiramente alcalinas (com calcário) e condiçōes redox redutoras são significativamente importantes para minimizar a remobilização dos metais ${ }^{(195-196)}$.

Outro aspecto que chamou a atenção foi a presença de elementos pouco comuns, como $\mathrm{Ce}$ e Sm, detectados através de MEV-EDX. Portanto, este é um tema interessante a ser abordado em função de ser um tanto improvável que se trate de uma ocorrência natural desses elementos.

Estudos de complexação de metais com íon polissulfeto deverão ser efetuados, porque à excessão de $\mathrm{As}, \mathrm{Sn}$ e $\mathrm{Sb}$, a formação de complexos de outros metais com ion polissulfeto não consta em livros, ou publicações, como observamos em nosso laboratório. Os experimentos por nós efetuados nos incentivam a isso. Consequentemente, num futuro próximo serão estudados a transferência de metais dos sedimentos à biota aquática.

Outros pontos ainda a serem estudados são as causas dos valores de $E_{H}$ em Barra Bonita, influenciada por despejos de efluentes de industrias alcooleiras e açucareiras da regiảo, bem como a forte influência do Rio Piracicaba.

\section{REFERÊNCIAS BIBLIOGRÁFICAS}

1 - A.Mudrock e S.D.MacKnight, "CRC Handbook of Techniques for Aquatic Sediments Sampling", CRC Press, Boca Raton, USA, (1991).

2 - U.Förstner e G.Müller, citados por Tessier et al, Can. J. Earth Sci., 17, 90, (1980).

3 - G.E. Hutchinson, A. Wollack e J.K.Setlow, Amer.Jour.Sci., 241, 533, (1943).

4 - H.Zullig, citado por U.Förstne:" em "Interactions between Sediments and Freshwater", Goltermen, H.L., The Hague, (1977). 
5 - J.O.Nriagu e J.M.Pacina, Nature, $\underline{\mathbf{3 3 3}}, 134,1988$.

6 - D.J.Casagrande e L.D.Erchull, Geochimica et Cosmochimica Acta, 40, $387,1976$.

7 - J.P.Giesy e L.A.Briese, Chem. Geol., 20, 109, 1977.

8 - M.L. Berrow e R.L.Mitchell, Earth Science, 71, 103, 1980.

9 - U.Förstner, em "Chemical Methods for Assessing Bioavailable Metals in Sludges and Soils", R. Leschber et al., Eds., Elsevier, Londres, 1985.

10 - H.D.L. Fiedler, "Método Común de Extraciones Sequenciales de Metales en Sedimentos: Estudio sobre la Preparación de un Material de Referencia Certificado", Tese de doutoramento, Universidade de Barcelona, (1995).

11 - A.A.Mozeto, "O manejo da Qualidade da Água e da Dinâmica do Sedimento e do Particulado da Represas do Guarapiranga e do Rio Grande, RMSP”, Projeto RHAE, processo n 610419/95-1, Universidade Federal de São Carlos, 1996.

12 - C.H.Mortimer, J.Ecol., $\underline{29}, 280,1941$.

13 - C.H.Mortimer, J.Ecol., $\underline{30}, 147,1942$.

14 - E.L. Zicker, K.C.Berger e A.D.Hasler, Limnol. Oceanogr., 1, 296, 1956.

15 - K.A Hudson-Edwards, M.G.Macklin, C.D.Cutris e D.J.Vaughan, Environ.Sci Technol, 30, 72, 1996. 
16 - M.Kersten e U.Förstner em "Trace Element Speciation: Analytical Methods and problems", G.E.Batley (Ed.), CRC Press, Boca Raton, USA, (1989).

17 - T.U.Aulitia e W.F.Pickering, Talanta, $\mathbf{Z}, 559,1988$.

18 - E.A.Jenne et al. "The Importance of Chemical Speciation in Environmental Processes", M.Berhard, F.E.Brinckman e P.J.Sadler (Eds.), Springer Verlag, Berlin, (1986).

19 - W.Stumm e J.J.Morgan, "Aquatic Chemistry", Wiley Interscience, USA, (1970).

20 - R.J.Gibbs, Nature, 180, 71, (1973).

21 - P.M.V.Nirel e F.M.M.Morel, Wat.Res., 24, 1055, (1990).

22 - J.C.Martin, P.Nirel e A.J.Thomas, Mar.Chem., 22, 313, (1987).

23 - L.J.A.Gerringa, Netherlands Journal of Sea Research, 27, 145, (1991).

24 - A.M.Gunn, D.T.E.Hunt e D.A.Winnard, Hydrobiologia, 188/189, 487, (1989).

25 - C.Kheboian e C.F.Bauer, Anal.Chem., 59, 1417, (1987).

26 - P.Quevalier et al., Fresenius J.Anal.Chem., $\underline{\mathbf{3 4 8}}$, 1693, (1994).

27 - H.D.Fiedler et al., Analyst, 119, 1109, (1994).

28 - D.L.Lake, P.W.W.Kirk e J.N.Lester, J.Environ.Qual., 13, 175, (1984). 
29 - A.Tessier e P.G.C.Campbell, Hydrobiologia, 149, 43, (1987).

30 - J.F.Lopez-Sanchez, citado por Fiedler, ref. 5.

31 - J.M.Martin, P.Nirel e A.J.Thomas, Mar.Chem., 22, 313, (1987).

32 - A.V.Hirner, Interm. J.Environ.Anal.Chem., 46, 77, (1992)

33 - W.F.Pickering, "Metal Ion Speciation-Soils and Sediments", Ore Geology, I

34 - A. Tessier e P.G.C.Campbell e M.Bisson, Anal.Chem., 51, 844, (1979).

35 - M. Kersten e U.Förstner, Wat. Sci. Techn., 18, 121, (1986).

36 - M.Kersten e U.Förstner, Mar.Chem., 22, 299, (1987).

37 - R.Bartlett e B.James, citados por M.Kersten e U.Förstner, ref.36.

38 - U.Schwertmann, citado por M.Kersten e U. Förstner, ref.16.

39 - R.M. Engler, J.M.Brannon e J.Rose, em " Chemistry of Marine Sediments", T.F.Yen, Ed., Ann. Harbor Sci Publ., Ann Harbor, 1977.

40 - B.A.Malo, Environ.Sci Technol, 11, 277, 1977.

41 - R.C.Sorensen, D.D.Oelsligle e D.Knudsen, Soil Science, 111, 352, 1971

42 - S.N.Luoma e G.W.Bryan, Science of the Total Environment, 17, 165, 1981.

43 - S.N.Louma, ibid, 28, 1, 1983. 
44 - M.Fiszman, W.C.Pfeiffer e L. Drude de Lacerda, Environ. Techn. Lett., $\underline{\mathbf{5}}$ 567, (1984).

45 - EPA-ROC "The Standard Methods for the Determination of Heavy Metals in Soils", National Institute of Environmental Analysis, Taipei, Taiwan, (1991).

46 - P.G.C.Campbell e R.Carignan, "Biologically Available Metals in Sediments", NRCC Report, 27694, Ottawa, 1988.

47 - Arbeitsgemeinschaft für die Reinhaltung der Elbe, Scwermetalldaten der Elbe, Hamburg, 1980.

48- Gemeinsames Bund/Länder-Meßprogram fúr die Nordsee, Wassergütedaten, 1980/1981, 1982.

49 - A.Mudroch e R.A.Boubonniere, ref.1, cap. 6.

50 - J.M.Wood et al., grupo de estudos de especiação de sistemas sob estresse em "The Importance of Chemical Speciation in Environmental Processes", M.Bernard, F.E.Brinckman e P.J.Sadler, (Eds.), Springer Verlag, Berlin, (1986).

51 J.C.Morris e W.Stumm, Advanced in Chemical Series, 67, R.F.Gould (Ed.), ACS, (1967).

52 - M.Whitfield, Limnol.Oceanogr., 14, 547, 1969).

53 - A.U.Shaikh et al., Nucl. Cher.. Waste Manage., 5, 237, 1985.

54 - A.U.Shaikh et al., ibid., 5, 337, 1985. 
55 - C.E.ZoBell, Amer. Assoc. Petroleum Geol., 30, 447, 1946.

56 - D.K.Nordstron, Geochimica et Cosmochimica Acta, 41, 1835, 1977.

57 - ASTM-APHA - "Standard Methods for the Examination of Water and Wastewater", M.A.H.Franson et al., Eds, $17^{2}$ ediçäo, 1989, Washington, DC.

58 - T.S.Light, Anal. Chem., 44, 1038, 1972.

59 - L.G.M. Baas-Beecking, I.R.Kaplan e D.Moore, J.Geol., $\underline{68}$, 243, 1960.

60 - D. Langmuir, in "Procedures in Sedimentary Petrology",R.E.Calver, Ed., Wiley-Interscience, New York, 1971.

61 - R.M.Garrels e C.L.Christ, "Solutions, Minerals and Equilibria", Harper and Row, New York, 1965.

62 - W.G.Breck, J.Mar.Res., 30, 121, 1972

63 - O.P.Bricker, Redox Potencial: It's measurement and Importance in Water Systems" em "Water Analysis", R.A. Minear e L.H.Keith, Eds., Academic Press, New York, 1982.

64 - R.M. Garrels, "Mineral Equilibria at Low Temperature and Pressure", Harper and Brothers, New York, 1960.

65 - R.D.Lindberg e D.D.Runnells, Science, 225, 925, 1984.

66 - L.E.Bagander e L.Niemisto, Estuarine Coast Mar.Sci., 6, 127, 1976.

67 - R.G.Bates, Crit.Rev. Anal.Chem., 10, 247, 1981. 
68 - R.A.Berner, Geochem.Cosmochim.Acta, 27, 563, 1963.

69 - B.L.Sharp, J.Anal.At.Spectrom., 1, 136R, 1986.

70 - D.Littlejohn, J.Anal.At.Spectrom., 4, 164R, 1989.

71 - I.Kojima e C.Lida, J.Anal.At.Spectrom., 2, 463, 1987.

72 - H.Willard, L.Merrit Jr. e J.Dean, "Análise Instrumental", Fundação Calouste Gulbe nkian, Portugal, 1974.

73 - P.Tiglea, dissertação de mestrado, Instituto de Química da Universidade de São Paulo, 1994.

74 - R.Rubio, Intern.J.Environ.Anal.Chem., 47, 99, 1992.

75 - R.A.Berner, Am.J.Sci., 265, 773, 1967.

76 - R.A.Berner T.Baldwin e G.R.Holdren, J.Sedim.Petrol., 49, 1345, 1981.

77 - R.A.Berner, Mar Geol., 12, 117, 1964

78 - R.A.Berner, Am. J. Sci., 268, 1, 1970.

79 - J. Ste-Marie, A.E.Thorma e A.O.Gubeli, Can. J. Chem., 42, 662, 1964.

80 - D.J.Vaughan e J.R.Craig, "Mineral Chemistry of Metal Sulfides", Cambridge University Press, New York, 1978.

81 - W.J.Adams et al., om "Aquatic Toxicology and Hazard Assessment: Seventh Symposium", R.D.Cardwell, R.Purdy e R.C.Bahner, (Eds.), American Society Testing Materials, Philadelphia, 1985. 
82 - R.C.Swartz et al., Mar.Environ.Res., 18, 133, 1985.

83 - P.F.Kemp e R.C.Swartz, Mar.Environ.Res., 26, 135, 1988.

84 - D.M.Di Toro e G.T.Ankley, Environ. Sci.Techn.,_26, 96, 1992.

85 - G.T.Ankley et al., Environ.Toxicol. Chem., 10, 1299, 1991.

86 - A.Carlson et al., Environ.Toxicol. Chem., 10, 1309, 1991.

87 - G.T.Ankley et al., Environ.Toxicol. Chem., 12, 315, 1993.

88- D. Howard e R.D.Evans, Environ.Toxicol. Chem., 12, 1051, 1993.

89 - A.M.Casas, Environ.Toxicol. Chem., 13, 529, 1994.

(1994).

90 - G.Krantzberg, Environ.Toxicol. Chem., 13, 1685, 1994.

91 - H.Brower, Environ.Toxicol. Chem., 14, 2, 1995.

92 - T.Frevert, Archiv für Hydrobiologie, 109, 1, 1987.

93 - E.E.Roden e J.H.Tuttle, Limnol.Oceanogr., 37, 725, 1992.

94 - ibid., Biogeochemistry, 22, 81, 1993.

95 - ibid., Mar.Ecol.Progr.Ser., 93, 101, 1993.

96 - M.Sato, Econ. Geol., 포, 1202, 1960 
97 - D.J.G.Ives e G.J.Jans, "Reference Electrodes", Academic Press, New York, 1961.

98 - M.S.Frant e J.W.Ross, Tappi, $\underline{\mathbf{5 3}}, \mathbf{1 7 5 3}, 1970$.

99 - E.W.Baumann, Anal.Chem., 46, 1345, 197.4.

100 - Orion Research Incorporated, Applications Bulletin $\mathbf{N}^{\circ} 12$, "Determination of Total Sulfide Content in Water", 1969.

101 - J.D.Cline, Limnology and Oceanograp/sy, 14, 454, 1969.

102 - W.Davison e J.P.Lishman, Analyst, 108, 1235, 1983.

103 - T.D.Rees, A.B.Gyllenspetz e A.C.Dockerty, ibid., 96, 201, 1971

104 - G.A.Cutter e T.J.Oatts, Anal.Chem., 59, 717, 1987.

105 - Hawke et al., Analyst, 110, 269, 1985.

106 - J.W.Morse et al., Earth Sci.Rev., 24, 1, 1987

107 - A. Barbanti e M.H.Bothner, Environmental Geology, 21, 3, 1993.

108 - A.J.de Groot, K.H.Zcchupje e W.Salomons, Hydrobiologia, 92, 689, 1982.

109 - A.J.Horowitz e K.A.Elrick, Environ. Technol. Lett., I 17, 1986.

110 - W.Salomons e Ü. Förstner, "Metals in the Hydrocycle", SpringerVerlag, Berlin, 1984. 
111 - F.Ackermann, H.Bergmann e U.Schleichert, Environ. Technol. Lett., 4 , 317, 1983.

112 - F.Ackermann, ibid., 1, 518, 1980.

113 - A.J.de Groot e K.H.Zcchuppe, Rapp P.V.Reun. Cons. Int. Explor. Mer, 181, 111, 1981.

114 - A.J.de Groot, K.H.Zcchuppe e W.Salomons, Hidrobiologia, 92 689, 1982.

115 - G.J.Wall, L.P.Wilding e N.E.Smeck, J.Environ. Qual., Z, 319, 1978.

116 - A.F.Padilha e F.Ambrozio-Filho, "Técnicas de analise Microestrutural's, Hemus Editora, São Paulo, 1985.

117 - G.W.Luther III et al., Mar.Pollut.Bull., 17, 535, 1986.

118 - A.L.Bitar e I.Bianchini Jr., I Seminário sobre Qualidade de Águas Continentais no Mercosul, pg. 312, Porto Alegre, Associaçåo Brasileira de Recursos Hídricos, 1994.

119 - M.J.Swift, D.W.Heal e J.M.Anderson, "Studies in EcologyDecomposition in Terrestrial Ecossistems", Blackwell, Oxford, 1979.

120 - A.L.S.Albuquerque, Dissertação de Mestrado, Universidade Federal de Såo Carlos, 1992.

121 - A.C.Redfield, Am.Sci., 46, 206, 1958.

122 - E.F.Idiz, D.Carlisle e I.R.Kaplan, Appl. Geochem., 1, 573, 1986.

123 - A.V.Hirner, K.Kritsotakis e H.J.Tobschall, ibid., $\underline{\mathbf{5}}$, 491, 1990. 
124 - E.M.Thurman, “Organic Geochemistry of Natural Waters', Martinus NijhoffM.Junk Publishers, The Hague, 1986.

125 - M Schnitzer e S.U. Kahn, "Humic Substances in the Environment", Marcel Decker, New York, 1972.

126 - J.Slavek, J.Wold W.F. Pickering, Talanta, 29, 743, 1982.

127 - CETESB - (1995) Relatório de qualidade de águas interiores do Estado de São Paulo, São Paulo.

128 - CETESB - (1994) Relatório de qualidade de águas interiores do Estado de São Paulo, São Paulo.

129 - CETESB - (1993) Relatório de qualidade de águas interiores do Estado de São Paulo, São Paulo.

130 - CETESB - (1992) Relatório de qualidade de águas interiores do Estado de São Paulo, São Paulo.

131 - I.S.Silva, Dissertação de Mestrado, Instituto de Geociências da USP, 1996.

132 - J.L.Santos, J.C.Derísio e E.G.Agudo, "Congresso Brasileiro de Engenharia Sanitária", Maceió, Alagoas, pg. 16, 1985.

133 - CETESB - Avaliação dos efeitos das regras operacionais do Alto Tietê no Médio Tietê Superior, 1985, São Paulo. 
134 - J.G.Tundisi e T.Matsumura-Tundisi, Limnology and Eutrophication of Barra Bonita Reservoir, São Paulo State, Southern Brasil. Ergebnisse der Limnologie, Advances in Limnology, Helf 33. E. Schweizerbart"sche Verlagsbuchhandlung-Stuttgart, 661, 1990.

135 - G.J.G.Eysink et al., 6th International Conference on the Conservation and Management of Lakes, Kasumigaura, Japão, 1995

136 - M.Marques, Saneamento Ambiental, 26, 16, 1994.

137 - M.Grimberg, T.Matsumura-Tundisi e A.C.Rietzler, Anais do I Simpósio de Ciências da Engenharia Ambiental, Universidade de São Paulo, Campus de São Carlos, 1996.

138 - R.A.Durst em "Monitoring Environmental Materials and Specimen Banking", N.P.Luepke, Ed., Martinus Nijhoff Ed., The Hague, 1979.

139 - W.W.Wood, "Guidelines for collection and field analysis of ground water samples for selected unstable constituents". Techniques of Water Resources Investigations of the United States Geological Survey, Washington, 1976.

140 - J.P.S.Valente, Dissertação de Mestrado, Instituto de Química da USP, 1983.

141 - J.Ravenda, Collet.Czech. Chem. Commun., ㅌ, 453, 1934.

142 - I.M.Koltoff e C.S.Miller, J.Am.Chem.Soc., $\underline{63}, 1405,1941$.

143 - W.Davison e S.I.Heany, Limnol.Oceanogr., 25, 153, 1980. 
144 - W.Davison, C.F.Wood e D.R.Turner, Nature, $\underline{925}, 1982$.

145 - J.A.Turner, R.H.Abel e R.A.Osteryoung, Analytical Chemistry, 47, 1343, 1975.

146 - W.Fresenius et al. (Eds.), “Water Analysis”, Springer-Verlag, Berlin, 1988.

147 - S.H.P.Serrano, Tese de Doutoramento, Instituto de Química da USP, 1988.

148 - A.Vogel, "Análise Inorgánica Quantitativa", 4" ed., Guanabara, Rio de Janeiro, 1986.

149 - J.C.Cornwell e J.W.Morse, Marine Chemistry, 22, 193, 1987.

150 - G.E.Batley e D.Gardner, Estuar.Coast Mar. Sci., ㄱ, 59, 1977.

151 - P.Lanza e P.L.Buldini, Analytica Chimica Acta, 70, 341, 1974

152 - T.Takahari e M. Kosaka, Bunseki Kagaku, 25, 192, 1976.

153 - M.J.Barcelona et al., Sampling Frequency for Ground-Water Quality Monitoring. EPA 600 S4/89/032, Illinois, 1989.

154 - P.O'neill, "Environmental Chemistry”, 2nd Ed., Chapman \& Hall, Londres, 1994.

155 - K.Wallmann et al., Intern. J. Environ. Anal. Chem., 51, 187, 1993. 
156 - T.S.Light, em "Ion-Seletive Electrodes", R.A.Durst, Ed., NBS Special Publication, Washington, 1969.

157 - G.Christian, "Instrumental Analysis”, John Wiley and Sons, New York, 1994.

158 - F.Rapin et al., Environ. Sci .Technol., 므, 836, 1986.

159 - R.Berner, J.Sed.Petrol., 51, 359, (1981).

160 - G.Scwarzenbach e A.Fisher, Helv.Chem. Acta, 43, 1365, 1960.

161 - A.Teder, Acta Chem. Scand., 25, 1722, 1971.

162 - D.T.Rickard, Am.J.Sci., 275, 636, 1975.

163 - J.Boulegue, C.R.Acad. Sci. Paris, Ser. D, 283, 591, 1976

164 - J.Boulegue e G.Michard, J.Fr.Hydrol., 25, 27, 1978.

165 - V.K.La Mer e A.S.Kenyon, J. Coll. Int. Sci., 2, 257, 1947.

166 - D.Pechansky e G.Valensi, J.Chim. Phys., $\underline{\mathbf{4 6}}$, 602, 1949.

167 - H.H.Voge, J.Amer.Chem.Soc., 61, 1032, 1939.

168 - M.Aceto et al., Intern. J. Environ. Anal. Chem., 55, 165, 1994.

169 - Ü. Förstner, “Interactions between Sediments and Freshwater", Ed. Göltermen, H.L., The Hague, 1977. 
170 - F.A.Esteves et al., Il Seminário Regional de Ecologia, Universidade Federal de São Carlos, 1981.

171 - F.A.Esteves e M.Tolentino, Ciência e Cultura, $\underline{\mathbf{3 8}}, 540,1986$.

172 - F.Feigl, "Spot Tests in Inorganic Analysis", Elsevier, Netherlands, 1958.

173 - S.K.Gupta e K.Y.Chen, Environ. Lett., 10, 129, 1975.

174 - R.Pardo et al., Intern. J. Environ. Anal. Chem. 41, 89, 1990

175 - R.L.Folk, "Petrology of Sedimentary Rocks", Austin, Texas, Humphill, 1974.

176 - M.Meybeck, Amer. J.Sci., 282, 401, 1982.

177 - Hedges et al., Limnol. Oceanogr., 31, 717, 1986.

178 - J. Buffle, "Complexation Reactions in Aquatic Systems", Ellis Horwood Ltd., Chichester, England, 1990.

179 - M.A.Rashid e L.H.King, Geochimica et Cosmochimica Acta, 34, 193, 1974.

180 - F.S.Brown et al., Geochimica et Cosmochimica Acta, 36, 1185, 1972.

181 - O.K.Bordovsky, Marine Geology, $\underline{3}, 3,1965$.

182 - K.M.Khailov, Geokhimiya, $\underline{\mathbf{5}}$, 595, 1968. 
183 - G.G.Choudry em "The Handbook of Environmental Chemistry", O.Hutzinger, Ed., Springer-Verlag, Berlin, 1982.

184 - J.Lawrence, Water Research, 14, 373, 1980.

185 - M.Schnitzer em “Soil Biochemistry", A.D.McLaren, Ed., Marcel Dekker, NY, 1971.

186 - Ü. Förstner e W.Salomons em "Metals and Their Compounds in the Environment", Ernest Merian, Ed., VCH, Weinheim, 1991.

187 - R.R.Brooks, B.J.Presley e E.I.R.Kaplan, Geochimica et Cosmochimica Acta, 32, 397, 1968.

188 - B.J.Presley et al., Geochimica et Cosmochimica Acta, 36, 1073, 1972.

189 - L.R.Gardner, Geochimica et Cosmochimica Acta, 쑈, 1297, 1974.

190 - H.L.Barnes e H. Czamanske em "Geochemistry of Hydrothermal Ore Deposits", H.L.Barnes, Ed., Holt, Rineart \& Winston, 1967.

191 - I. Krauskopf, Geochimica et Cosmochimica Acta, 19, 1, 1956.

192 - Y.Chen e S.Morris, Geochimica et Cosmochimica Acta, 35, 1321, 1971.

193 - M.A.Rashid e J.D.Leonard, Chemical Geology, 11, 89, 1973. 
194 - E. Olausson, "Methods for the Chemical Analysis of Sediments", FAO, Fisheries Technolology Paper $n^{\circ}$ 137, Food and Agriculture Organizations of United Nations, Roma, 1975.

195 - R.P.Gambrell, C.N.Reedy e R.A.Khalid, J.Water Pollut.Control Fed., $\underline{\mathbf{5}}$, $1201,1983$.

196 - W.Calmano, "Behaviour of Dredged Mud after Stabilization with Different Additives", em J.W.Assink e W.J.Van der Brink (Eds.), "Contaminated Soil", Martinus Nijhoff Publishers, Dordrecht, 1986. 